\title{
Fish and Aquatic Macroinvertebrate Communities in the Cacapon River, West Virginia
}

Stephen Selego

West Virginia University

Follow this and additional works at: https://researchrepository.wvu.edu/etd

\section{Recommended Citation}

Selego, Stephen, "Fish and Aquatic Macroinvertebrate Communities in the Cacapon River, West Virginia" (2011). Graduate Theses, Dissertations, and Problem Reports. 3324.

https://researchrepository.wvu.edu/etd/3324

This Thesis is protected by copyright and/or related rights. It has been brought to you by the The Research Repository @ WVU with permission from the rights-holder(s). You are free to use this Thesis in any way that is permitted by the copyright and related rights legislation that applies to your use. For other uses you must obtain permission from the rights-holder(s) directly, unless additional rights are indicated by a Creative Commons license in the record and/ or on the work itself. This Thesis has been accepted for inclusion in WVU Graduate Theses, Dissertations, and Problem Reports collection by an authorized administrator of The Research Repository @ WVU. For more information, please contact researchrepository@mail.wvu.edu. 
Fish and Aquatic Macroinvertebrate Communities in the Cacapon River, West Virginia

\title{
Stephen Selego
}

\begin{abstract}
Thesis submitted to the
Davis College of Agriculture, Natural Resources and Design

at West Virginia University

in partial fulfillment of the requirements for the degree of
\end{abstract}

Master of Science
in

Wildlife and Fisheries Resources

James T. Anderson, Ph.D., Committee Co-Chair

Stuart A. Welsh, Ph.D., Committee Co-Chair

George T. Merovich, Jr., Ph.D., Committee Member

Division of Forestry and Natural Resources

Morgantown, West Virginia

2011

Keywords: bass, flight behavior, indices of biotic integrity, natural channel design, sunfish 


\section{ABSTRACT \\ Fish and Aquatic Macroinvertebrate Communities in the Cacapon River, West Virginia}

\section{Stephen Selego}

Stream restoration, involving both in-stream and riparian techniques, was conducted on an impaired stretch of the Cacapon River, West Virginia. Fish and aquatic macroinvertebrate communities were sampled before, during, and after restoration at the restoration site and four other sites (two impaired, two natural) to determine the success of the restoration project. Overall, bluntnose minnows (Pimephales notatus) were the most abundant fish, and riffle beetles (Stenelmis sp.) were the most abundant macroinvertebrates collected. Both communities were negatively impacted by the restoration efforts in the short-term, but recovered quickly. Fish communities returned roughly to the state observed pre-restoration. Macroinvertebrate communities increased in health post-restoration; they resembled other impaired stretches prior to restoration, and resembled natural stretches following restoration. Local macroinvertebrate abundance, in particular, responded quickly. Therefore, macroinvertebrates were stronger indicators of site health than were fish in the Cacapon River.

Centrarchid nesting behavior and response to perceived harm were assessed using several environmental variables, collected from nest sites and random sites during the summer of 2010. A priori general linear models were generated to explain nest site selection, nest success, and response to perceived harm based on the environmental variables. Overall, four species of centrarchids were observed nesting: longear sunfish (Lepomis megalotis), redbreast sunfish (Lepomis auritus), rock bass (Ambloplites rupestris), and smallmouth bass (Micropterus dolomieu). All four species nested in habitat significantly different from random sites in the river, and therefore were selecting for specific habitat. Longear sunfish also nested in habitat significantly different from the other three species. The differences in site selection were largely determined by distance to other centrarchid nests, distance to in-stream cover objects, and water velocity. Human observer-induced threat response in longear sunfish was influenced by male size, water velocity, and distance to cover. Due to a general lack of nest reuse and commonality of nests located in substantial water current, it is likely that female choice and protection from predators are driving site selection in male centrarchids more than minimization of energy expenditure. 


\section{ACKNOWLEDGMENTS}

I give special thanks to Dr. James Anderson for admitting me to West Virginia University, and for providing me with and guiding me through two exciting thesis projects. In addition, I owe my gratitude to Dr. Stuart Welsh for his help with fish sampling techniques, fish identification, and data analysis; and Dr. George Merovich for his support with project development and statistical analysis. This thesis would not have succeeded without them.

I am indebted to a number of graduate students and University employees who generously assisted with field work and field season preparations. In no particular order, this list includes Jonathan Pitchford, Charneé Lee Rose, Katie and Noah McCoard, Crissa Cooey, Tristan Gingerich, and Walter Veselka. Thank you to West Virginia Student Chapter of The Wildlife Society for their help with invasive vegetation removal. Of course, none of the field work would have been possible without the continued cooperation of the Cacapon landowners.

I thank a number of agencies for providing funding, logistical support, and expertise for this project. These include the National Fish and Wildlife Foundation (NFWF), Chesapeake Bay Trust, FishAmerica Foundation, National Oceanic and Atmospheric Administration (NOAA), Farm Service Agency (FSA), Natural Resource Conservation Service (NRCS), the West Virginia Department of Environmental Protection (WV DEP), West Virginia Conservation Agency (WVCA), Canaan Valley Institute (CVI), Cacapon and Lost Rivers Land Trust (CLRLT), and the employees of Reymann Memorial Farm in Wardensville, WV.

I am incredibly grateful to have the support of my family. They always had faith in my ability to succeed in graduate school, even when I didn't. And finally, I am so thankful for the daily encouragement of Charneé Lee Rose. I'm confident this project would have fallen flat without her. 


\section{Table of contents}

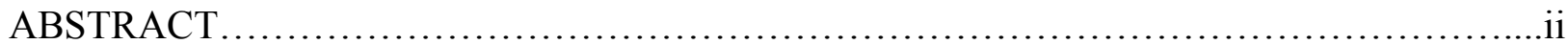

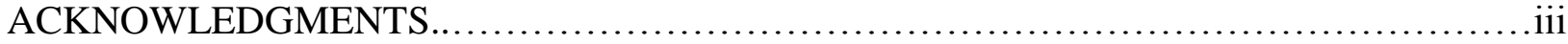

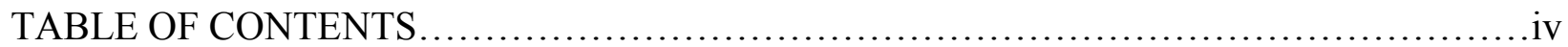

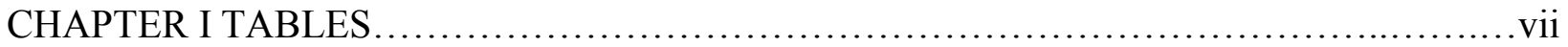

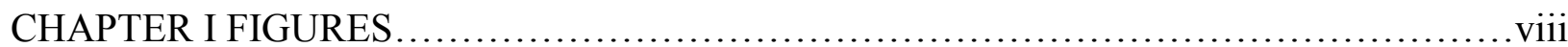

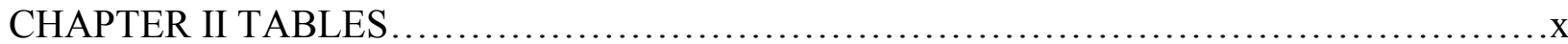

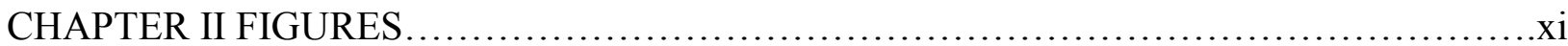

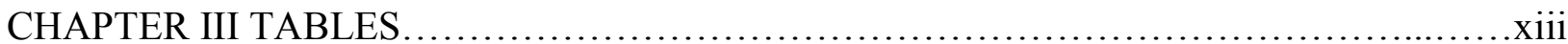

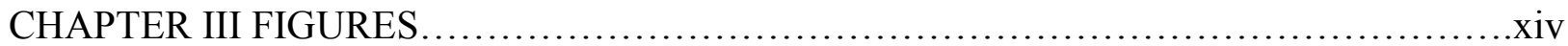

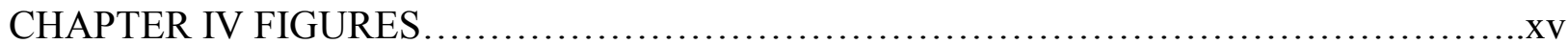

LIST OF APPENDICES ...................................................................

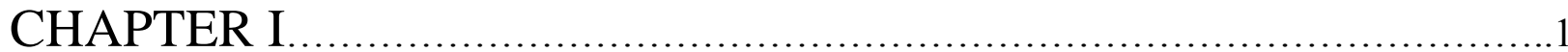

PROJECT OVERVIEW: OBJECTIVES AND LITERATURE REVIEW FOR STREAM RESTORATION AND CENTRARCHIDAE NESTING BEHAVIOR IN THE CACAPON

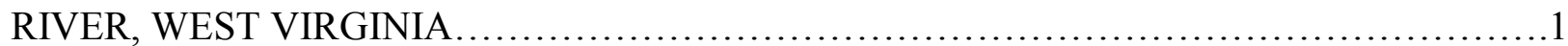

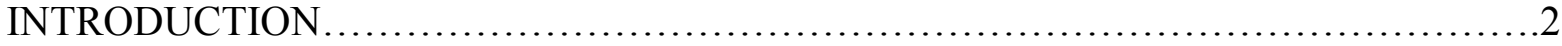

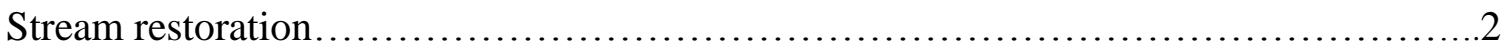

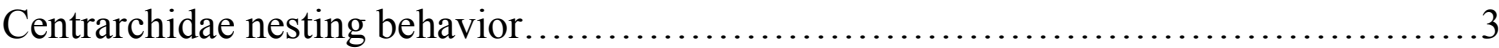

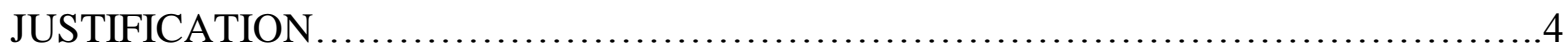

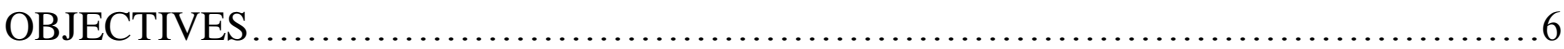

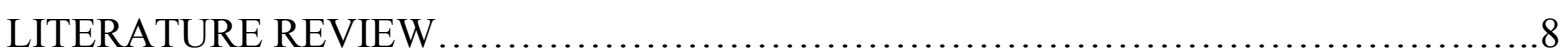

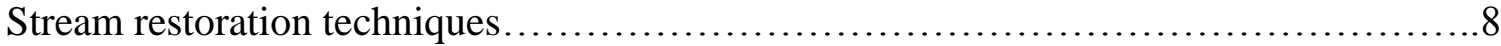

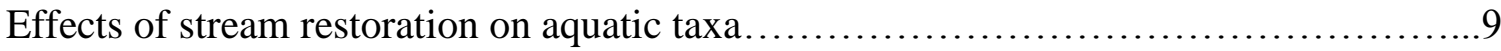

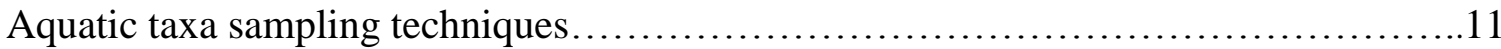

Aquatic taxa assessment and analysis........................................... 13

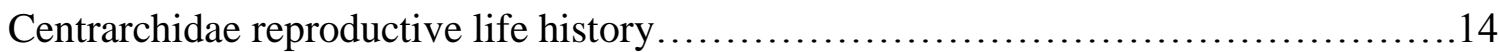

Centrarchidae nest site selection..................................................

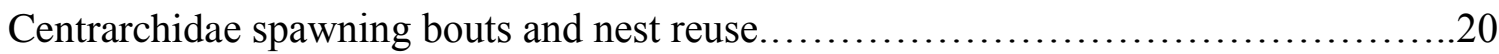

Centrarchidae response to perceived harm.............................................

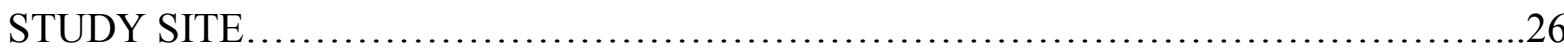

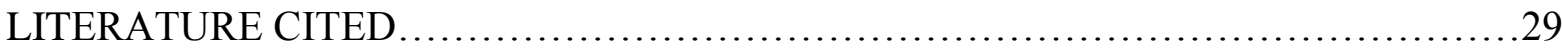

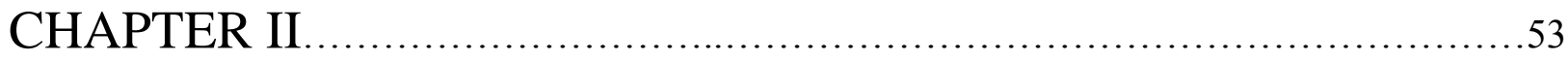

COMMUNITY-LEVEL RESPONSE OF FISH AND AQUATIC MACROINVERTEBRATES

TO STREAM RESTORATION IN A THIRD-ORDER TRIBUTARY OF THE POTOMAC

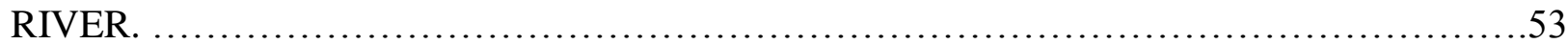

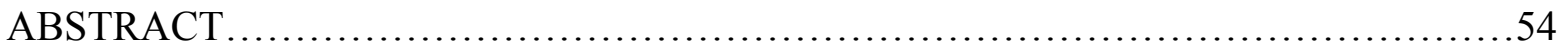

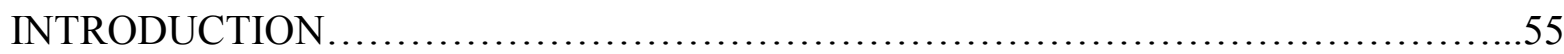




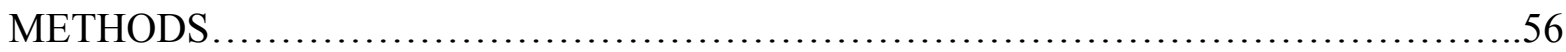

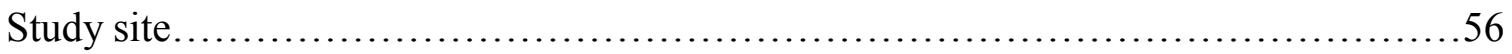

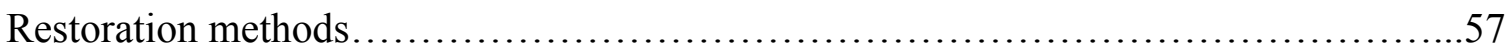

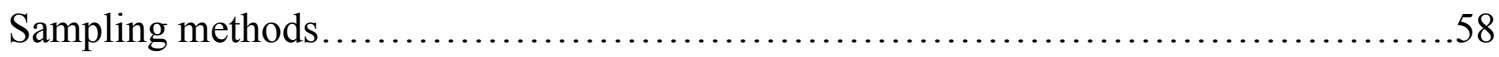

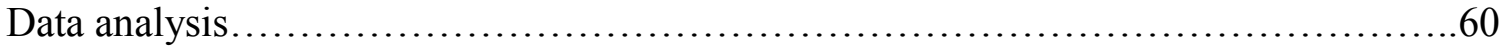

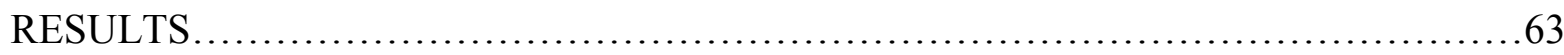

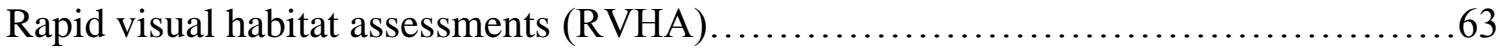

Macroinvertebrate community assessment.....................................63

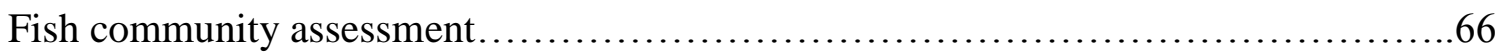

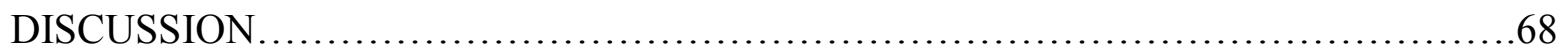

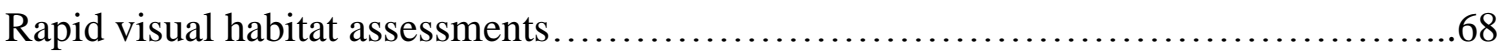

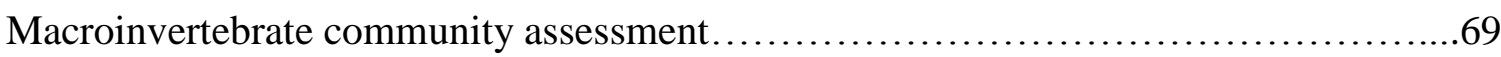

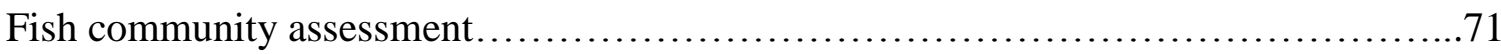

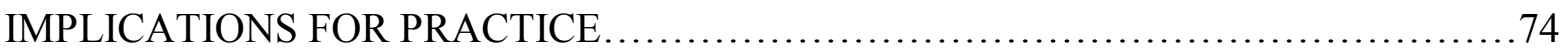

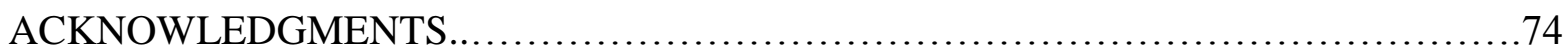

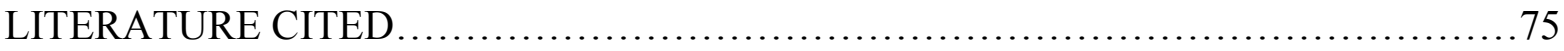

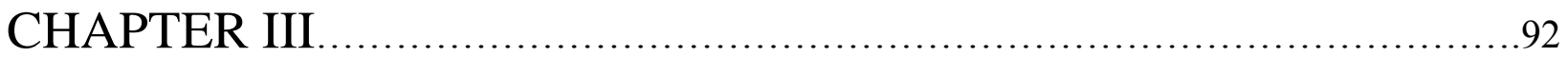

MALE CENTRARCHIDAE NESTING BEHAVIOR IN THE CACAPON RIVER,

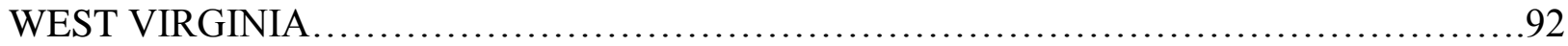

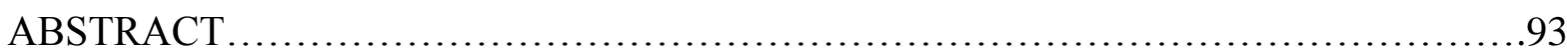

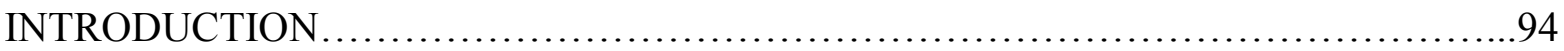

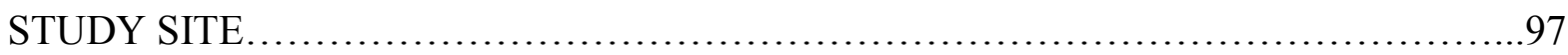

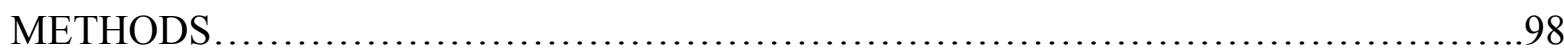

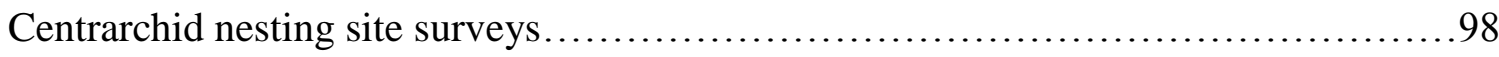

Centrarchid site selection analysis.............................................. 101

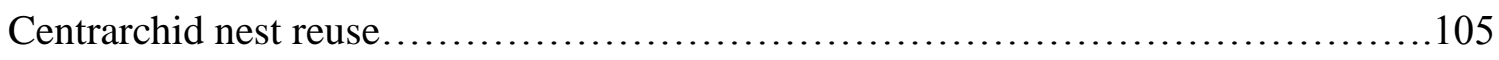

Centrarchid response to perceived harm...........................................

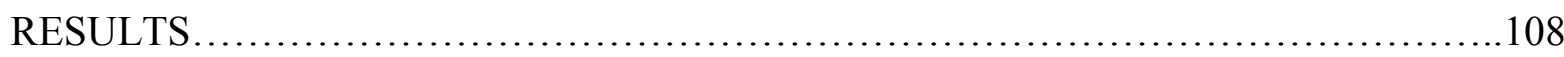

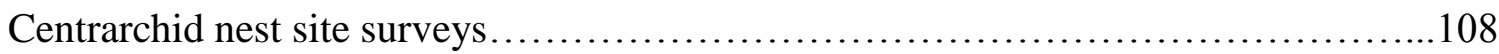

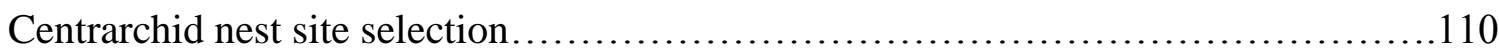

Centrarchid response to perceived harm..........................................112

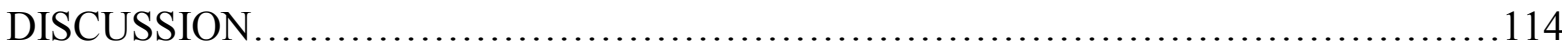

Centrarchid species nest site selection..........................................114

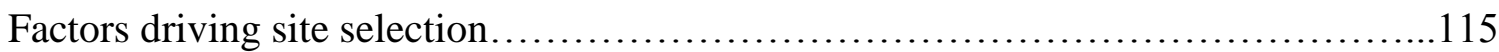

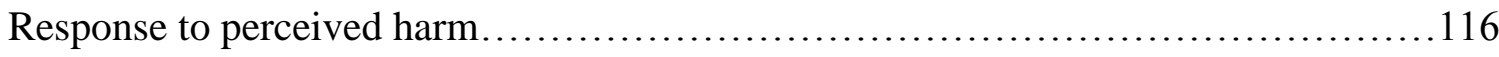

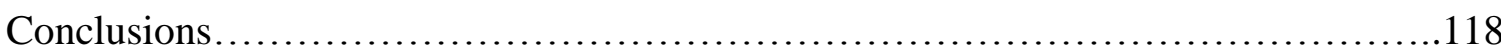

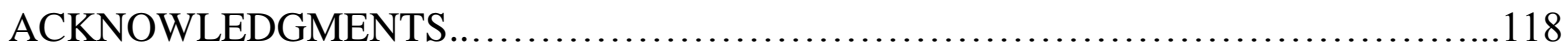

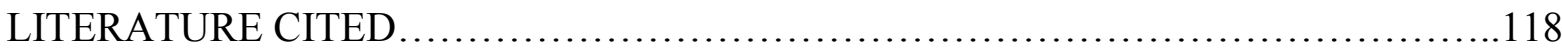


CHAPTER IV.

CONCLUSIONS, MANAGERIAL CONSIDERATIONS, AND FUTURE RESEARCH

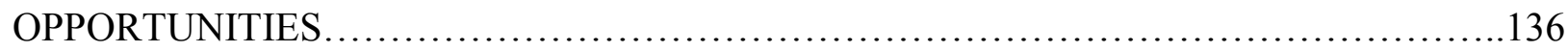

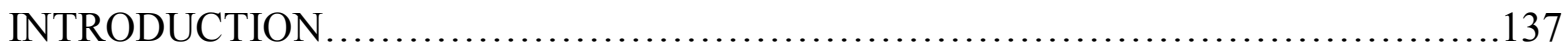

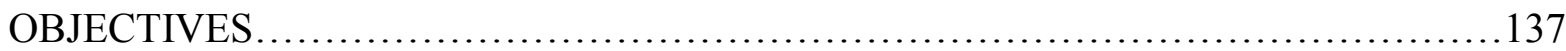

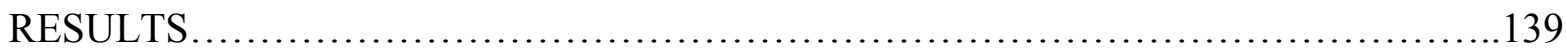

Response of aquatic taxa to stream restoration..................................... 139

Centrarchidae nesting behavior............................................... 141

Centrarchid response to perceived harm.............................................. 143

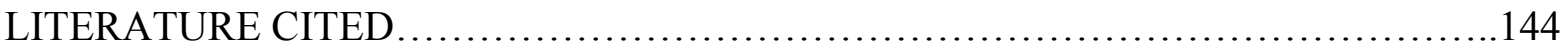




\section{Ch 1: List of tables}

Table 1: Plantings in zone A (water edge to top of bank) of the Cacapon River, West Virginia, USA restoration stretch. Woody vegetation species were planted to establish a riparian buffer and reduce erosion from the newly constructed banks....................................... 38

Table 2: Plantings in zone B (above bank) of the Cacapon River, West Virginia, USA restoration stretch. Woody vegetation species were planted to establish a riparian buffer and reduce sedimentation and pollutant runoff from the surrounding pastureland. The 'P?' column indicates whether the tree or shrub is a pollinator species.......................................... 39 


\section{Ch 1: List of figures}

Figure 1: Photograph of the restoration stretch prior to restoration, taken during the Winter 2010 sampling season, March 2010. Mr. Rudolph's property is on the left, Mr. Frye's property on the

right

Figure 2: Photograph of the restoration stretch (Mr. Frye's property) taken during restoration (Spring 2010 sampling season), May 2010

Figure 3: Photograph of the restoration stretch taken during the Summer 2010 sampling season, July 2010. Mr. Rudolph's property is on the left, Mr. Frye's property on the right. Note the native tree plantings (with white tree tubes) and log vane on the right, and the electric exclusion

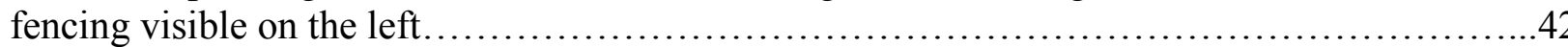

Figure 4: Diagram of the river bank before and after excavation of sediment to construct an

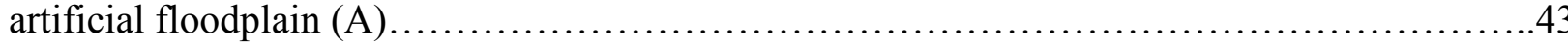

Figure 5: Location of the two planting zones along the restoration stretch. Zone a stretches from the water's edge to the top of the excavated bank, and zone b stretches away from the top of the bank ( $35 \mathrm{~m}$ on the Rudolph bank and $50 \mathrm{~m}$ on the Frye bank). Each zone received a combination planting of woody vegetation species adapted to the zone's level of moisture...

Figure 6: Map of the locations of all nine log vanes (three on the Rudolph bank and six on the Frye bank) placed in the Cacapon River. These vanes were stabilized with gravel, boulders, and

metal cables......................................................................45

Figure 7: Structure of log vanes placed in the Cacapon River; in all nine were constructed within the restoration stretch to direct water away from weakened sections of the bank. The blue arrows indicate flow direction of the thalweg....................................................

Figure 8: Map of the restoration stretch, two control stretches, and two reference stretches in the Cacapon River. Upstream control (impaired stretch, but not receiving restoration) denoted 'UC', downstream control denoted 'DC'. Upstream reference (unimpaired, natural stretch) denoted 'UR', downstream reference denoted 'DR'. The restoration stretch denoted 'Re'...

Figure 9: Photograph of the upstream control stretch (impaired stretch not receiving restoration) taken during the Spring 2010 sampling season, May 2010. Note the heavily eroding, sloped bank and low channel fullness (visible point bars) ........................................... 48

Figure 10: Photograph of the downstream control stretch (impaired stretch not receiving restoration) taken during the Winter 2010 sampling season, March 2010. Note the lack of riparian buffer and eroding banks (visible on the right)

Figure 11: Photograph of the upstream reference stretch (unimpaired, natural stretch) taken during the Winter 2010 sampling season, March 2010. Note the healthy riparian buffer, full channel, and gently sloping banks... 
Figure 12: Photograph of the downstream reference stretch (unimpaired, natural stretch) taken during the Winter 2010 sampling season, March 2010. Note the healthy riparian buffer and

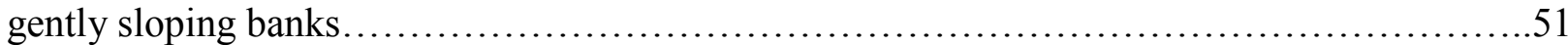

Figure 13: Map of the Cacapon River stretch in Hardy and Hampshire Counties, West Virginia that was surveyed for centrarchid nests, showing the upper and lower stretch boundaries........52 


\section{Ch 2: List of tables}

Table 1: Rapid visual habitat assessment (RVHA) metrics for riffle-dominated rivers based on Barbour et al. (1999).....................................................................

Table 2: Names, explanations, justifications, and scoring of aquatic macroinvertebrate metrics used to assess sampling stretch health in the Cacapon River, WV, 2009-2010. As stretch health improves, positive (Pos) scoring metrics increase and negative (Neg) scoring metrics decrease.

Table 3: Names, explanations, and scoring of fish metrics used in the Daniels et al. (2002) (DS) and McCormick et al. (2001) (MC) indices of biotic integrity, used to assess sampling stretch health on the Cacapon River, WV, 2009-2010. As stretch health improves, positive (Pos) scoring metrics increase and negative (Neg) scoring metrics decrease.

Table 4: Pearson's correlation coefficients and associated permutational p-values (1000 randomizations) for relations between macroinvertebrate index of biotic integrity metrics and nonmetric multidimensional scaling (NMDS) ordination for the macroinvertebrate community sampled during the summers of 2009 and 2010 from the Cacapon River, WV. An asterisk indicates significance at $\alpha=0.05$. Two asterisks indicates significance at $\alpha=0.01 \ldots \ldots \ldots \ldots . .84$ 


\section{Ch 2: List of Figures}

Figure 1: Map of the restoration stretch, located in Hardy and Hampshire Counties, West Virginia in the Northeastern United States. Upstream control (impaired stretch, but not receiving restoration) denoted ' $U C$ ', downstream control denoted 'DC'. Upstream reference (unimpaired, natural stretch) denoted 'UR', downstream reference denoted 'DR'. The restoration stretch denoted 'Re'

Figure 2: Overall abundances of Ephemeroptera, Plecoptera, and Trichoptera (EPT) taxa collected from the Cacapon River from all five stretches during all four sampling seasons, 2009-

2010 .

Figure 3: Cacapon River restoration, control, and reference sampling stretch rank sum scores for macroinvertebrate modified index of biotic integrity (IBI) across all sampling seasons: prerestoration (two samples), during restoration, and post-restoration. Upstream control (impaired stretch, but not receiving restoration) denoted ' $U C$ ', downstream control denoted 'DC', upstream reference (unimpaired, natural stretch) denoted 'UR', and downstream reference denoted 'DR'. The restoration stretch is denoted as 'Rest'.

Figure 4: Nonmetric multidimensional scaling (NMDS) ordination plot for aquatic macroinvertebrate communities at all sampling stretches (stress $=10.6$ for 2-dimensional solution). Stretches are labeled by treatment category: upstream control (impaired stretch, but not receiving restoration) denoted ' $\mathrm{UC}$ '; downstream control denoted 'DC'; upstream reference (unimpaired, natural stretch) denoted 'UR'; and downstream reference denoted 'DR'. 'Pre' denotes the restoration stretch prior to restoration, and 'Post' denotes the restoration stretch after restoration. Selected macroinvertebrate taxa are positioned in the ordination as weighted averages. Vector lengths indicate relative correlative strength of macroinvertebrate community

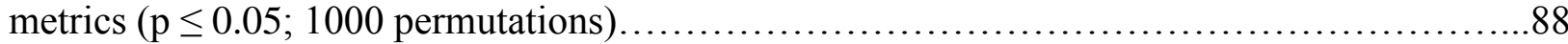

Figure 5: Cacapon River restoration, control, and reference sampling stretch for Daniels et al. (2002) fish index of biotic integrity (IBI) scores across all sampling seasons. Upstream control (impaired stretch, but not receiving restoration) denoted ' $U$ Con', downstream control denoted 'D Con', upstream reference (unimpaired, natural stretch) denoted 'U Ref', and downstream reference denoted 'D Ref'. The restoration stretch is denoted as 'Rest'.

Figure 6: Cacapon River restoration, control, and reference sampling stretch for McCormick et al. (2001) fish index of biotic integrity (IBI) scores across all sampling seasons. Upstream control (impaired stretch, but not receiving restoration) denoted 'U Con', downstream control denoted 'D Con', upstream reference (unimpaired, natural stretch) denoted 'U Ref', and downstream reference denoted ' $\mathrm{D}$ Ref'. The restoration stretch is denoted as 'Rest....

Figure 7: Nonmetric multidimensional scaling (NMDS) ordination plot for fish communities at all sampling stretches ( stress $=11.3$ for 2-dimensional solution). Stretches are labeled by treatment category: upstream control (impaired stretch, but not receiving restoration) denoted 'UC'; downstream control denoted 'DC'; upstream reference (unimpaired, natural stretch) denoted 'UR'; and downstream reference denoted 'DR'. 'Pre' denotes the restoration stretch 
prior to restoration, and 'Post' denotes the restoration stretch after restoration. Selected fish species are positioned in the ordination as weighted averages. Vector lengths indicate relative correlative strength of fish community metrics based on an index of biotic integrity suggested by

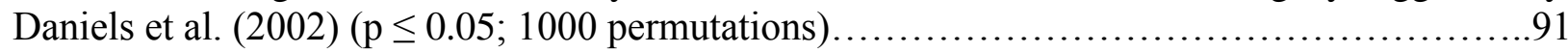




\section{Ch 3: List of tables}

Table 1: Means and standard errors for the environmental variables measured at each centrarchid nest and random site. Significant Kruskal-Wallis tests $(\alpha=0.003)$ followed with pair-wise MannWhitney tests (significant differences denoted by lower-case numerals). Species coded as rock bass (AMRU), redbreast sunfish (LEAU), longear sunfish (LEME), and smallmouth bass (MIDO), and random sites (Ran).

Table 2: Candidate models for nest site selection in the four nesting species of centrarchids, with the associated Akaike information criterion values adjusted for small sample size $\left(\mathrm{AIC}_{\mathrm{c}}\right)$, estimable parameters $(\mathrm{K}), \Delta_{\mathrm{i}}\left(\mid \mathrm{AIC}_{\mathrm{i}}-\mathrm{AIC}\right.$ lowest $\left.\mid\right)$, and relative model weights $\left(\mathrm{w}_{\mathrm{i}}\right)$. Models based on distance to nearest nest (DN), distance to cover (DC), distance to deepwater (DD), distance to shore (DS), water depth (WD), water velocity(WV), canopy cover (CC), silt and clay proportion (ST), sand proportion (SD), gravel proportion (GR), and cobble and bedrock proportion (CO). Candidate models with the lowest $\Delta_{\mathrm{i}}$ are given with standard errors in the footnotes.

Table 3: Candidate models for nest success (presence of eggs) in longear sunfish (Lepomis megalotis) and rock bass (Ambloplites rupestris), with the associated Akaike information criterion values adjusted for small sample size $\left(\mathrm{AIC}_{\mathrm{c}}\right)$, estimable parameters $(\mathrm{K}), \Delta_{\mathrm{i}}$ $\left(\mid \mathrm{AIC}_{\mathrm{i}}-\mathrm{AIC}\right.$ lowest $\left._{\mathrm{f}}\right)$, and relative model weights $\left(\mathrm{w}_{\mathrm{i}}\right)$. Models based on male size (MS), nesting date (DA), distance to nearest nest (DN), distance to cover (DC), distance to deepwater (DD), distance to shore (DS), water depth (WD), water velocity (WV), canopy cover (CC), silt/clay proportion around nest (ST), silt/clay proportion in nest (SN), sand proportion around nest (SD), gravel proportion around nest (GR), gravel proportion in nest (GN), and cobble/bedrock proportion around nest (CO). Candidate models with the lowest $\Delta_{\mathrm{i}}$ are given with standard errors in the footnotes

Table 4: Candidate models for response to perceived harm in longear sunfish (Lepomis megalotis), with the associated Akaike information criterion values adjusted for small sample size $\left(\mathrm{AIC}_{\mathrm{c}}\right)$, estimable parameters $(\mathrm{K}), \Delta_{\mathrm{i}}\left(\left|\mathrm{AIC}_{\mathrm{i}}-\mathrm{AIC} \mathrm{l}_{\text {lowest }}\right|\right)$, and relative model weights $\left(\mathrm{w}_{\mathrm{i}}\right)$. Models for each of four response variables based on male size (MS), distance to nearest nest (DN), distance to cover (DC), distance to deepwater (DD), distance to shore (DS), water depth (WD), water velocity (WV), canopy cover (CC), gravel proportion around the nest (GR), and gravel proportion in the nest $(\mathrm{GN})$. Candidate models with the lowest $\Delta_{\mathrm{i}}$ are given with standard

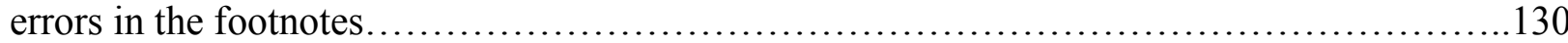




\section{Ch 3. List of figures}

Figure 1: Map of the Cacapon River stretch that was surveyed for centrarchid nests, showing the sites where nests were found. Each labeled site represents any number of closely clustered nests, not individual nests.

Figure 2: Proportion of objects that serve as the closest cover object from each centrarchid nest for rock bass (Ambloplites rupestris, AMRU), redbreast sunfish (Lepomis auritus, LEAU), longear sunfish (Lepomis megalotis, LEME), and smallmouth bass (Micropterus dolomieu, MIDO), and for random sites on the Cacapon River, WV, 2010. SAV=submerged aquatic vegetation

Figure 3: Nonmetric multidimensional scaling (NMDS) ordination plot $(\mathrm{k}=2)$ for longear sunfish nests (Lepomis megalotis, M), redbreast sunfish (L. auritus, U), rock bass (Ambloplites rupestris, A), smallmouth bass (Micropterus dolomieu, S), and random sites (r), based on average values for each environmental variable within species. Overlay depicts weighted means of distance to nearest nest (DN), distance to cover (DC), distance to deepwater (DD), distance to shore (DS), water depth (WD), water velocity (WV), canopy cover (CC), silt and clay proportion (Silt), sand proportion (Sand), gravel proportion (Grav), and cobble and bedrock proportion (Cobb). 


\section{Ch 4: List of figures}

Figure 1: Photograph of Stephen Selego and Tristan Gingerich with a backpack electrofishing unit and holding bucket, taken at the downstream reference stretch, August 2010 ....

Figure 2: Photograph of Charneé Lee Rose and Jon Holmes performing a kick sample using a hand screen to collect aquatic macroinvertebrates at the upstream control stretch, May 2010.

Figure 3: Photograph of one of the large fish-holding bins spaced evenly through the sampling stretch, August 2010.......................................................... 148

Figure 4: Photograph of Stephen Selego, Jonathan Pitchford, and Crissa Cooey identifying a fish sample at the downstream reference stretch, August 2010.

Figure 5: Photograph of a longnose dace (Rhinichthys cataractae) with anomalies (Black Spot Disease), collected at the downstream control stretch during the Summer 2010 sampling season, August 2010 .

Figure 6: Photograph of a macroinvertebrate sample in a hand screen, collected from the downstream reference stretch during the Winter 2010 sampling season, March 2010. Genera present include Corydalus, Ephemera, Psephenus, Hagenius, and Tipula.

Figure 7: Photograph of a redbreast sunfish (Lepomis auritus), collected during electrofishing, August 2010. Redbreast sunfish were the most abundant centrarchids during electrofishing, but redbreast sunfish nests were found less frequently than longear sunfish (Lepomis megalotis) and rock bass (Ambloplites rupestris) nests. ...

Figure 8: Photograph of a common sunfish nesting area, July 2010. The area is representative of many sites within the Cacapon that support the nesting of multiple species: low water velocity, shallow depth, adequate cover, and gently sloping gravel bank. Of the four species observed nesting in the Cacapon, only smallmouth bass (Micropterus dolomieu) did not nest at this site.

Figure 9: Photograph of an active centrarchid nest, taken close-up to show general lack of fine sediments within the nest (yet abundance of fine sediments surrounding the nest), July 2010. These particles are removed from the nest prior to spawning, to prevent eggs from suffocating. This particular nest belonged to a longear sunfish (Lepomis megalotis), and was located just outside of a large longear sunfish colony. 


\section{List of appendices \\ Ch 1 appendices}

Appendix 1a: Example of the data sheet used to select the restoration stretch of the Cacapon

River. The criteria and rankings were modified from Strager et al. (2011)...................155 


\section{Ch 2 appendices}

Appendix Ib: Rapid visual habitat assessment (RVHA) scores, following Barbour et al. 1999, for the five Cacapon restoration project sampling stretches, taken Summer 2009 (pre-restoration) and Summer 2010 (post-restoration).

Appendix IIb: List of aquatic macroinvertebrates collected from all sampling stretches in the Cacapon River with associated functional feeding groups (Mandaville 2002).................160

Appendix IIIb: Aquatic macroinvertebrate metric 'total taxa', with scores across all sampling stretches and sampling seasons. Upstream control (impaired stretch, but not receiving restoration) denoted ' $\mathrm{UC}$ ', downstream control denoted ' $\mathrm{DC}$ ', upstream reference (unimpaired, natural stretch) denoted 'UR', and downstream reference denoted 'DR'. The restoration stretch is denoted as 'Rest'.

Appendix IVb: Aquatic macroinvertebrate metric 'total genera', with scores across all sampling stretches and sampling seasons. Upstream control (impaired stretch, but not receiving restoration) denoted ' $U C$ ', downstream control denoted 'DC', upstream reference (unimpaired, natural stretch) denoted ' $U R$ ', and downstream reference denoted 'DR'. The restoration stretch is denoted as 'Rest'.

Appendix Vb: Aquatic macroinvertebrate metric 'total Ephemeroptera, Plecoptera, and Trichoptera (EPT) taxa', with scores across all sampling stretches and sampling seasons. Upstream control (impaired stretch, but not receiving restoration) denoted 'UC', downstream control denoted 'DC', upstream reference (unimpaired, natural stretch) denoted 'UR', and downstream reference denoted 'DR'. The restoration stretch is denoted as 'Rest'.

Appendix VIb: Aquatic macroinvertebrate metric 'percent Ephemeroptera, Plecoptera, and Trichoptera (EPT)', with scores across all sampling stretches and sampling seasons. Upstream control (impaired stretch, but not receiving restoration) denoted 'UC', downstream control denoted 'DC', upstream reference (unimpaired, natural stretch) denoted 'UR', and downstream reference denoted 'DR'. The restoration stretch is denoted as 'Rest'.

Appendix VIIb: Aquatic macroinvertebrate metric 'percent Chironomidae', with scores across all sampling stretches and sampling seasons. Upstream control (impaired stretch, but not receiving restoration) denoted ' $\mathrm{UC}$ ', downstream control denoted 'DC', upstream reference (unimpaired, natural stretch) denoted ' $U R$ ', and downstream reference denoted 'DR'. The restoration stretch is denoted as 'Rest'

Appendix VIIIb: Aquatic macroinvertebrate metric 'percent dominant two taxa', with scores across all sampling stretches and sampling seasons. Upstream control (impaired stretch, but not receiving restoration) denoted ' $\mathrm{UC}$ ', downstream control denoted 'DC', upstream reference (unimpaired, natural stretch) denoted 'UR', and downstream reference denoted 'DR'. The restoration stretch is denoted as 'Rest'. 
Appendix IXb: Aquatic macroinvertebrate metric 'Hilsenhoff Biotic Index score', with scores across all sampling stretches and sampling seasons. Upstream control (impaired stretch, but not receiving restoration) denoted ' $\mathrm{UC}$ ', downstream control denoted ' $\mathrm{DC}$ ', upstream reference (unimpaired, natural stretch) denoted 'UR', and downstream reference denoted 'DR'. The restoration stretch is denoted as 'Rest'.

Appendix Xb: Aquatic macroinvertebrate metric 'total abundance', with scores across all sampling stretches and sampling seasons. Upstream control (impaired stretch, but not receiving restoration) denoted ' $\mathrm{UC}$ ', downstream control denoted 'DC', upstream reference (unimpaired, natural stretch) denoted 'UR', and downstream reference denoted 'DR'. The restoration stretch is denoted as 'Rest'.

Appendix XIb: Functional feeding group proportions present at each stretch during each sampling season. Upstream control (impaired stretch, but not receiving restoration) denoted 'UC', downstream control denoted 'DC', upstream reference (unimpaired, natural stretch) denoted 'UR', and downstream reference denoted 'DR'. The restoration stretch is denoted as 'Re'. 'Post' refers to post-restoration samples, 'Dur' refers to during restoration samples, and 'Pre' refers to pre-restoration samples from summer 2009 (S) and winter 2010 (W).

Appendix XIIb: List of fish species collected during electrofishing in the Cacapon River at all

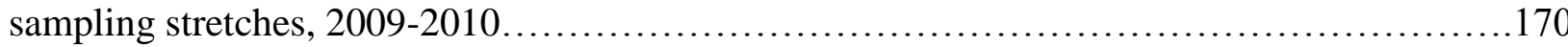

Appendix XIIIb: Bar graph of fish species collected during electrofishing in the Cacapon River at all sampling stretches across all sampling seasons, 2009-2010.

Appendix XIVb: Bar graph of centrarchid species collected during electrofishing in the Cacapon River at all sampling stretches across all sampling seasons, $2009-2010 \ldots \ldots \ldots \ldots \ldots \ldots \ldots \ldots \ldots 172$

Appendix XVb: Daniels et al. (2002) index of biotic integrity (IBI) metric scores at each sampling stretch during each sampling season. Upstream control (impaired stretch, but not receiving restoration) denoted ' $\mathrm{UC}$ ', downstream control denoted ' $\mathrm{DC}$ ', upstream reference (unimpaired, natural stretch) denoted 'UR', and downstream reference denoted 'DR'. The restoration stretch is denoted as 'Rest'.....

Appendix XVIb: McCormick et al. (2001) index of biotic integrity (IBI) metric scores at each sampling stretch during each sampling season. Upstream control (impaired stretch, but not receiving restoration) denoted ' $\mathrm{UC}$ ', downstream control denoted 'DC', upstream reference (unimpaired, natural stretch) denoted 'UR', and downstream reference denoted 'DR'. The

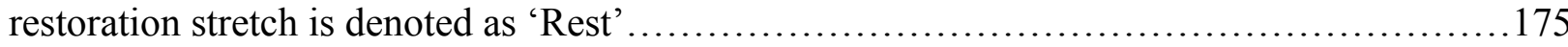

Appendix XVIIb: Pearson's correlation coefficients and associated permutational p-values (1000 randomizations) for relations between fish index of biotic integrity (Daniels et al. 2002, McCormick wt al. 2001) metrics and nonmetric multidimensional scaling (NMDS) ordination for the fish community sampled during the summers of 2009 and 2010 from the Cacapon River, WV. An asterisk indicates significance at $\alpha=0.05$ 


\section{Ch 3 Appendices}

Appendix Ic: Example of a hand-drawn map of a centrarchid nesting area, used to relocate

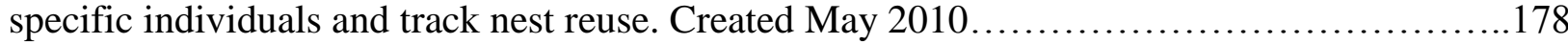

Appendix IIIc: Graphical representation of the temporal range of nesting behavior among the four centrarchid species located in the Cacapon River....

Appendix IIIc: Pie charts of substrate class composition in and around the nests of longear sunfish, visually assessed and averaged over each nest found.

Appendix IVc: Pie charts of substrate class composition in and around the nests of rock bass, visually assessed and averaged over each nest found.

Appendix Vc: Pie charts of substrate class composition in and around the nests of redbreast sunfish, visually assessed and averaged over each nest found.

Appendix VIc: Pie charts of substrate class composition in and around the nests of smallmouth bass, visually assessed and averaged over each nest found.

Appendix VIIc: Pie chart of substrate class composition at the random sites within the centrarchid nesting stretch, visually assessed and graphically averaged across all sites sampled.

Appendix VIIIc: Nonmetric multidimensional scaling (NMDS) ordination plot $(\mathrm{k}=3)$ for longear sunfish nests $(\mathrm{M})$ and random sites $(\mathrm{r})$, with environmental variable overlay. Stress $=15.87 \ldots . .185$

Appendix IXc: Nonmetric multidimensional scaling (NMDS) ordination plot $(\mathrm{k}=3)$ for rock bass nests (A) and random sites (r), with environmental variable overlay. Stress $=15.43$.

Appendix Xc: Nonmetric multidimensional scaling (NMDS) ordination plot $(\mathrm{k}=3)$ for redbreast sunfish nests (U) and random sites (r), with environmental variable overlay. Stress $=15.07 \ldots . .187$

Appendix XIc: Nonmetric multidimensional scaling (NMDS) ordination plot $(\mathrm{k}=3)$ for smallmouth bass nests $(\mathrm{S})$ and random sites (r), with environmental variable overlay.

Stress $=14.14$

Appendix XIIc: Nonmetric multidimensional scaling (NMDS) ordination plot $(\mathrm{k}=3)$ for longear sunfish nests (M) and rock bass nests (A), with environmental variable overlay. Stress=16.60.

Appendix XIIIc: Nonmetric multidimensional scaling (NMDS) ordination plot $(\mathrm{k}=3)$ for longear sunfish nests $(\mathrm{M})$ and redbreast sunfish nests (U), with environmental variable overlay.

Stress $=15.48$. 
Appendix XIVc: Nonmetric multidimensional scaling (NMDS) ordination plot $(\mathrm{k}=3)$ for longear sunfish nests $(\mathrm{M})$ and smallmouth bass nests $(\mathrm{S})$, with environmental variable overlay.

Stress $=14.61$

Appendix XVc: Nonmetric multidimensional scaling (NMDS) ordination plot $(\mathrm{k}=3)$ for redbreast sunfish nests (U) and rock bass nests (A), with environmental variable overlay. Stress $=15.42$. . .

Appendix XVIc: Nonmetric multidimensional scaling (NMDS) ordination plot $(\mathrm{k}=3)$ for smallmouth bass nests (S) and rock bass nests (A), with environmental variable overlay.

Stress $=13.43$.

Appendix XVIIc: Nonmetric multidimensional scaling (NMDS) ordination plot $(\mathrm{k}=3)$ for redbreast sunfish nests $(\mathrm{U})$ and smallmouth bass nests $(\mathrm{S})$, with environmental variable overlay.

Stress $=12.27$.

Appendix XVIIIc: Results for occupancy estimations conducted on 30 nesting longear sunfish males $(n=30)$, and approached 5 times each $(k=5)$, following the Geissler Fuller (G.F. method). Average detection probability across all surveys was 0.719 . 


\title{
CHAPTER I
}

PROJECT OVERVIEW: OBJECTIVES AND LITERATURE REVIEW FOR STREAM RESTORATION AND CENTRARCHIDAE NESTING BEHAVIOR IN THE CACAPON RIVER, WEST VIRGINIA

\author{
Stephen Selego \\ sselego@gmail.com \\ West Virginia University \\ Division of Forestry and Natural Resources \\ PO Box 6125 \\ Morgantown, WV 26506
}

Written in the style of:

Restoration Ecology 


\section{Introduction}

\section{Stream Restoration}

Healthy lotic systems (streams and rivers) provide many important ecological services and support diverse aquatic biological communities (Arthington et al. 2010). Restoration practices are becoming increasingly important to maintain system integrity in the face of negative anthropogenic activity. While restoration often seeks to improve biological community health, different restoration techniques have different effects (Lepori et al. 2005; Alexander \& Allan 2007). In-stream structures increase habitat diversity, and in turn increase aquatic taxa diversity (Johnson et al. 2002; Radspinner et al. 2010). Established riparian buffers reduce erosion and pollutant runoff, increasing the abundances of intolerant taxa (Sweeney et al. 2004; Teels et al. 2006; Miller et al. 2010).

Natural stream channel design (NSCD) applies many restoration techniques to the project stretch to imitate and ultimately recreate a "reference reach" (Rosgen 1998). Successful NSCD improves the physical (bank stability, water temperature), chemical (nitrogen and phosphorus inputs), and biological (biodiversity, biomass) conditions of the stretch (Keystone Stream Team 2003) and results in stable conditions (able to carry floods and sediments without significant structural change) (Nagle 2007). Restoration efforts following NSCD create a stream condition such that over time the stretch will return to and remain at a natural state without assistance (Keystone Stream Team 2003). Improper implementation of these principles (such as disregard for specific channel roughness or the clearing of riparian vegetation during construction projects) can lead to project failure, or a channel more impaired than it was before restoration (Kondolf et al. 2001).

Post-restoration sampling, which measures the effects of past projects on biological communities, is extremely important (Miller et al. 2010; Selvakumar et al. 2010). Unfortunately, 
post-project evaluation is quite rare (Kondolf \& Micheli 1995; Alexander \& Allan 2007). We tracked the effects of restoration on a stretch of the Cacapon River, West Virginia, following instream and stream-bank techniques based on NSCD principles. Our objectives were to compare the fish and macroinvertebrate communities in the restoration stretch before, during, and after application of techniques to those collected from impaired control stretches and natural reference stretches.

\section{Centrarchidae Nesting Behavior}

The males of all centrarchid species (family Centrarchidae, sunfish and bass) construct circular nest-depressions by fin-fanning, and keep the nests clear of large and fine sediments, pieces of vegetation, and other materials throughout the spawning bout (Breder 1936; Thorp 1988). Nest site selection is based on a range of environmental variables that vary depending on species, habitat type, time of year, and male size. These variables include water depth (Breder 1936; Bietz 1981; Helfrich et al. 1991), water velocity (Bietz 1981; Winemiller \& Taylor 1982; Noltie \& Keenleyside 1987), and proximity to in-stream cover objects (Mueller 1980; Noltie \& Keenleyside 1987). Some species also nest colonially. This behavior enables predator mobbing, which reduces individual energy expenditure in nest guarding, and thus improves the rate of nest success (Breder 1936; Gross and MacMillan 1981).

Centrarchid species generally have multiple spawning bouts within a season, and individual males often spawn multiple times (Gross and Nowell 1980; Cote and Gross 1993; Danylchuk and Fox 1996; Cargnelli and Neff 2006). Having multiple bouts protects against inconsistent environmental conditions typical of many freshwater systems (Winemiller and Taylor 1982; Noltie and Keenleyside 1987; Fox and Crivelli 1998). Centrarchids nesting after the first bout may reuse other nests to preserve the energy required in nest construction (Breder 1936; Gross and Nowell 1980; Thorp 1988; Jennings 1991). 
Nest-guarding centrarchids are preyed upon by a number of aquatic and terrestrial predators. Continuation of nest- and egg-tending behavior in the presence of such predators decreases the probability of survival of the adult male, but in turn protects the nest from piscivores, brood predators, and brood parasites. Parental investment during consistent threat of nest-predation will vary (in time spent nest-guarding, etc.) based on the value and needs of the current offspring (Cooke et al. 2008). Nest abandonment behavior in response to predation threat, therefore, should be balanced by perceived future reproductive fitness (Pressley 1981). When exposed to perceived threats, male centrarchids spend less time on their nests and less time tending to the nests while guarding them (Mueller 1980; Winkelman 1996). However, when driven from their nests, the males returned to their nests more quickly when eggs were present than when the nests were empty (Colgan 1988).

Little research has been conducted on the differences in nest site selection and nest reuse in sympatric centrarchid species. Additionally, few studies have examined the influence of the environmental characteristics of nesting sites on flight behavior due to perceived harm in male centrarchids. This study measured nest site characteristics in four species in order to determine which characteristics differentiate nesting habitat use. Multiple aspects of flight behavior were also studied and linked to specific nest site characteristics to determine which affected the magnitude of the response.

\section{Justification}

Restoration of impaired stretches of streams and rivers is a common practice designed to improve biological communities, preserve stream bank integrity, and prevent the input and transport of harmful chemicals downstream. However, few studies have conducted extensive 
surveys on the local biological communities following restoration to determine the effects of the restoration efforts. This study provides an opportunity to samples these communities before, during, and after restoration. In addition, some studies that follow restoration initiatives with sampling have detected little (or even negative) impacts of the restoration on in-stream organisms (Kondolf 1995). However, any study that tracks the impacts of restoration adds to our understanding of how to conduct restoration effectively. The stretch of the Cacapon River involved in restoration is larger than most lotic systems that undergo similar restoration. Therefore, any results collected from the restoration at the Cacapon River will help improve future projects.

Centrarchids are popular sport fish, and often important members of freshwater communities. Their abundance and adaptability also make them good research subjects. The most common studies involving sunfish focus on niche partitioning as it relates to foraging habits (Werner \& Hall 1975, 1977, 1979; Mittelbach 1984), due to the high degree of sympatry and niche overlap in centrarchid species.

Centrarchid spawning behavior, and specifically the habitat characteristics involved in nest-site selection, has become a popular topic as well. The majority of these studies have been conducted in lakes, perhaps because they are both easier to sample from than rivers and have qualities that are simpler to replicate experimentally. In addition, a large proportion of sunfish spawning studies (in lentic and lotic systems) have been conducted in Ontario, Canada and Michigan, with comparatively little from the rest of the United States (Garvey et al. 2002, Gross \& Nowell 1980, Ridgway et al. 1991). My study offers the opportunity to observe the nesting behavior of centrarchid species in a West Virginia river, and therefore would add to a relatively shallow pool of data. 
Numerous spawning studies have mentioned the tendency of centrarchids to reuse nest sites, both intra- and interspecifically (Breder 1936; Gross \& Nowell 1980; Noltie \& Keenleyside 1986; Thorp 1988; Jennings 1991). However, few previous studies have focused on this behavior. This study specifically examined the frequency of nest reuse, the tendency for each species of centrarchid in a community to reuse nests, and the probability that nest reuse is due to habitat preferences and not due to the allure of pre-nested river substrate.

Behavioral response to the threat of harm or predation is becoming increasing common in centrarchid research (Winkelman 1996; Cooke et al. 2008). However, these studies focus on the effects the presence or absence of eggs have on the magnitude of response. No study found has determined the influence of the environmental characteristics of nesting sites on flight behavior due to perceived harm. I measured multiple aspects of flight behavior in male centrarchids in order to link them to specific nest site characteristics.

\section{Objectives}

The community-level response to stream restoration study was based on the following objectives, with the corresponding hypotheses listed below.

1. Use a modified IBI to determine the health of the macroinvertebrate communities in the restoration, control, and reference stretches of the Cacapon River prior to, during, and following restoration efforts.

$\mathrm{H}_{0}$ : Macroinvertebrate IBI scores are identical among study stretches and among sampling seasons

$\mathrm{H}_{\mathrm{a}}$ : Macroinvertebrate IBI scores will differ among study stretches, and the restoration stretch score will increase following restoration efforts

2. Use two fish IBIs to determine the health of the fish communities in the restoration, control, and reference stretches of the Cacapon River prior to, during, and following restoration efforts.

$\mathrm{H}_{0}$ : Fish IBI scores are identical among study stretches and among sampling seasons 
$\mathrm{H}_{\mathrm{a}}$ : Fish IBI scores will differ among study stretches, and the restoration stretch score will increase following restoration efforts

The Centrarchidae nesting behavior study was based on the following objectives, with the corresponding hypotheses listed below.

1. Collect environmental characteristic data from each centrarchid nest found, along with physical data on the male guarding each nest (size, species, etc.), within the study stretch of the Cacapon River to determine which characteristics affect nest location.

$\mathrm{H}_{0}$ : Centrarchid males nest indiscriminately within the study stretch

$\mathrm{H}_{\mathrm{a}}$ : Environmental and physical characteristics of the nest site and male will affect the location of nests; specifically, centrarchids will select sites with shallow water, minimal water velocity, and proximity to upstream cover objects

2. Monitor all centrarchid nests found to determine which received eggs, and which were abandoned before mating occurred, and determine which environmental and physical characteristics affect nest success.

$\mathrm{H}_{0}$ : Nest success is not based on environmental or physical characteristics of the nest site or male

$\mathrm{H}_{\mathrm{a}}$ : Nest success is largely based on specific characteristics, including male size, timing during the spawning season, and proximity to other centrarchid nests

3. Revisit all previously located nests to determine if male centrarchids are reusing previously constructed nests.

$\mathrm{H}_{0}$ : Male centrarchids are not preferentially reusing nests

$\mathrm{H}_{\mathrm{a}}$ : Male centrarchids are selectively reusing nests as opposed to constructing new nests

4. Perform experimental predation response studies on at least one third of the centrarchid nests located, and record each male's behavior.

$\mathrm{H}_{0}$ : Behavioral response to the threat of predation will be independent of the corresponding environmental and physical characteristics of the nest site and male

$\mathrm{H}_{\mathrm{a}}$ : Behavioral response to threat of predation will reflect the fitness of the male, status of the guarded nest, and degree of protection available within the environment surrounding the nest 


\section{Literature Review}

\section{Stream Restoration Techniques}

The term 'restoration', as it applies to streams and rivers, refers to a variety of procedures. These include but are not limited to the placement of simple and complex in-stream structures, the input of spawning gravel, the establishment of riparian buffers, and limitations on access for people and livestock (Opperman \& Merenlender 2004). All of these techniques have the ultimate goal of improving the ecological status of a degraded habitat or protecting the surrounding land from future erosion (Chapman 1999). Even small changes in a stream's substrate size and composition, organic matter content, or habitat heterogeneity can influence biological communities; and therefore most lotic systems could be improved with properly implemented restoration techniques (Berkman \& Rabeni 1986).

Simple in-stream structures such as root wads and boulders are often added to lotic environments to increase habitat heterogeneity (Lepori et al. 2005). More complex in-stream structures generally perform additional tasks. Vanes are lines of large woody debris or rocks which extend from the bank and direct flow away from areas of high erosion. Ideally, vanes are angled $30^{\circ}$ upstream from the bank (Johnson et al. 2002). Cross vanes are U-shaped vanes which extend from bank to bank, and can shift the position of a river's thalweg. W-weirs are specialized forms of cross-vanes that create two scour pools as water passes over them. They also generate relatively uniform water velocities downstream (Johnson et al. 2002). However, installation of such structures can cause more harm than good if not performed by experts, and can be expensive (Opperman \& Merenlander 2004).

Establishment of riparian buffers is less expensive than in-stream structures, although it has much less immediate impact on the restoration area. Although U.S. legislation (Farm 
Security and Rural Investment Act of 2002) emphasizes the use of forested buffers, grass buffers can be equally effective (Sweeney et al. 2004). Both buffer forms excel at intercepting pollutant runoff, increasing water clarity, and reducing bank erosion (Sweeney et al. 2004; Teels et al. 2006). Bank erosion in particular is important to reduce, as erosion from agricultural lands contributes greatly to a river's sediment load. For example, over $67 \%$ of the sediment input into rivers in North Carolina is caused by agricultural erosion (Lenat 1984). Forested buffers also serve to reduce water temperature by providing cover, and provide constant supplies of fine organic matter as a food source for invertebrates (Opperman \& Merenlender 2004, Teels et al. 2006).

Improved buffers, habitat heterogeneity, and channel form (increased sinuosity) may be created with more passive techniques as well. In Mendocino County, California, fence installation was found to encourage the maturation of riparian zones by preventing access to the rivers by cattle (Opperman \& Merenlender 2004).

\section{Effects of Stream Restoration on Aquatic Taxa}

Simple restoration techniques, such as the addition of boulders or large woody debris to rivers and streams, are cost-efficient, but have not always proven to substantially improve biotic richness. Such techniques applied to the Ume River in northern Sweden did not cause a statistically significant increase in total macroinvertebrate abundance or richness over an 8-year span. This was attributed to the failure to restore vegetation on the river banks (Lepori et al. 2005). In California streams, however, woody debris increased habitat for steelhead trout (Oncorhynchus mykiss). Although this debris was added to the stream naturally, artificially added debris should have similar effects (Opperman \& Merenlender 2004). 
As mentioned, bank erosion is a major source of sedimentation, and can be reduced through restoration of riparian buffers. Invertebrate biomass was negatively correlated with sedimentation in the Colorado River (Osmundson et al. 2002). However, restoring a localized bank does not guarantee substantially reduced sediment input. Osmundson et al. (2002) found that the wash load of fine sediments in the Colorado River increased with movement downstream; that is, upstream erosion was largely responsible for sediment downstream. Similar effects occurred in Virginia, where the best responses of aquatic communities to buffer establishment came from first or second order streams (where the effects of the restoration were not overwhelmed by upstream influence) (Teels et al. 2006).

Riparian buffers also inhibit agricultural runoff, which negatively impacts fish indices of biotic integrity (IBIs) (Teels et al. 2006). Runoff also reduces diversity and abundance of intolerant species (Ephemeroptera, Plecoptera, and Trichoptera), which are eliminated from such degraded streams (Lenat 1984). However, this effect may also be caused by simple lack of cover (in addition to the input of sediment and chemicals). Sweeney et al. (2004) found that the decreased water temperature and increased shelter caused by forested banks caused improved total abundance of macroinvertebrates in streams in the eastern US. Although fish abundances were not significantly greater in forested stretches, compared to deforested stretches, the difference may still have been ecologically significant (Sweeney et al. 2004). In addition to preventing further bank erosion, proper buffers and in-stream structures can allow banks to rebuild themselves (Johnson et al. 2002).

Ecological communities require time to recover following restoration. The techniques involved in the restoration may temporarily increase sedimentation and reduce in-stream habitat. The time required for benthic macroinvertebrates to return to the restored stretch varies based on 
ecological condition of the stream system and surrounding watershed, and the season during which restoration occurred (Muotka et al. 2001; Spanhoff \& Arle 2007). Recovery of aquatic communities can occur a few months after restoration, or may require more than 5 years (Moerke et al. 2004; Muotka et al. 2001).

\section{Aquatic Taxa Sampling Techniques}

Traditionally, water quality monitoring was used to assess the health of lotic systems. Since the early 1980s, a switch has been made to biological assessments (Angermeier \& Karr 1986). Specific sampling protocol, like restoration protocol, is quite varied. Three main groups are commonly sampled: periphyton, benthic macroinvertebrates, and fish (Barbour et al. 1999). However, most studies focus on fish and/or macroinvertebrates, partly due to the correlation between periphyton and macroinvertebrate abundance and biomass (Osmundson et al. 2002). Sampling multiple trophic levels (e.g., fish and macroinvertebrates) also increases the chances of detecting the true level of recovery of the restored stretch(es) (Adams et al. 2002).

Each of the aforementioned faunal groups has its pros and cons. Aquatic invertebrates are relatively sedentary, and thus more affected by localized disturbances. The range of taxa is

usually large, which increases the chance that some specific group will be impacted by initial stress or by the restoration efforts. However, laboratory sorting and identification can be difficult and time consuming. Additionally, species prone to drift through the water table may be collected from areas they are not normally found, and influence final invertebrate metrics (Berkman \& Rabeni 1986). Fish are more easily recognized as important to an aquatic ecosystem by the general populace, are easier to identify in the field than macroinvertebrates, are longerlived than most invertebrates, and their higher trophic levels may reflect impacts on entire 
aquatic communities (Berkman \& Rabeni 1986, Fausch et al. 1990). However, sampling techniques can be notoriously unrepresentative (Gray et al. 2005).

Kick samples, using square-meter or D-frame kick nets, are the most common method for collecting macroinvertebrates (Lenat 1984, 1988; Barbour et al. 1999). Kick samples are usually only performed in relatively shallow riffles, which contain the most biomass (Barbour et al. 1999; Osmundson et al. 2002). Deeper waters can be sampled using dip net sweeps, or electroshocking (which induces drift-behavior, where the invertebrates can be collected in kick nets) (Lenat 1988; Lepori et al. 2005). Visual surveys may be added as necessary. For instance, if empty mussel shells are found littering the banks of a stream, time may be devoted to locating live specimens (Lenat 1988).

Fish-sampling techniques for restoration areas usually involve electricity, which temporarily stuns fish and makes them easier to see (their lighter-colored undersides often become visible when they invert) and to capture. Backpack electrofishing is the most common procedure, as it can be used to sample a range of habitats with a small crew of people (Larimore 1961; Angermeier \& Winston 1998; Lepori et al. 2005). Additional electricity-based sampling techniques use electrofishing boats and electric seines (Angermeier \& Karr 1986; Osmundson et al. 2002). Minnow seines are also frequently used, due to the decreased risk of harming the sampled fish (Angermeier \& Karr 1986; Berkman \& Rabeni 1986; Teels et al. 2006). Seines may also be used due to their increased efficiency (compared to electrofishing) at collecting certain fish species, such as darters and small cyprinids (Larimore 1961).

In addition to the restoration sites, two types of control sites must be sampled. First, at least one true control site must be selected. That is, a site with a similar level of degradation as the original (unrestored) restoration site (Chapman 1999). Reference sites are also needed, and 
represent what one hopes to achieve through restoration efforts. Although many studies choose a single reference site, this is not ideal, as it indicates that only one natural stream state is considered acceptable (Chapman 1999).

\section{Aquatic Taxa Assessment and Analysis}

The original index of biotic integrity (IBI) was developed by James Karr in 1981 for assessing western fish communities. The IBI consisted of 12 individual metrics, including total species and total hybrids (Angermeier \& Karr 1986). Each metric was assigned a value of 1, 3, or 5 for the stream in question. A 5 indicated that the value of the metric was similar to that obtained from a local stream of ideal natural condition. A 3 indicated some deviation from the reference stream, and a 1 indicated a large deviation (Teels et al. 2006). IBIs have a high degree of flexibility (e.g., they can incorporate presence/absence or quantitative data) (Fausch et al. 1990). However, for an IBI to be of any use, it must be tailored to the fauna of the particular region it intends to examine (Teels et al. 2006).

An IBI developed for the mid-Atlantic replaced total darter species with total benthic insectivorous species, and total hybrids with total individuals due to local abundances (Daniels et al. 2002). Furthermore, some studies either support or oppose the inclusion of young-of-the-year fish in the IBI (Sweeney et al. 2004). Excluding young-of-the-year generally reduces the IBI by eliminating rare species (which are often only represented by young) from the total species metric (Angermeier and Karr 1986).

Many specialized macroinvertebrate IBIs have also been created. A benthic IBI (B-IBI) was developed for the Tennessee Valley in 1994, and was based mainly on taxa richness for intolerant species (Ephemeroptera, Plecoptera, Trichoptera), and abundances of tolerant species (Corbicula, Oligochaeta) and trophic guilds (predators, filterers, etc.) (Kerans \& Karr 1994). The 
main concern with a macroinvertebrate IBI is that different groups can be identified to different taxonomic levels (Lenat 1988). There is also disagreement as to the ideal level of identification, with family-, genus-, and species-level identification all in use (Lenat 1988; Kerans \& Karr 1994; Barbour et al. 1999).

Individual metrics are often used separately, outside of an IBI, to examine the health of a benthic macroinvertebrate community. For instance, 'percent individuals per trophic guild' provides information on the saturation of certain niches (Berkman \& Rabeni 1986). The proportion of shredders, scrapers, and filterers in a sample are positively correlated with stream health (Barbour et al. 1996). Taxa richness is also a common stand-alone metric. As water quality is reduced, intolerant species are quickly eliminated, thus reducing total taxa richness. Influx of more tolerant species rarely exceeds the dropout of intolerant species (Lenat 1984; Lepori et al. 2005).

Abundance biomass comparison (ABC) plots can be used to assess communities of either macroinvertebrates or fish. This plots the abundance and biomass of each species (or genus) against its rank among all species within these categories. In polluted sites, the abundance curve usually lies above the biomass curve (polluted communities are often dominated by a large number of small organisms). The opposite is true for relatively natural sites (Chapman 1999).

Fish communities can also be analyzed using non-IBI methods. Species richness in fish, for instance, behaves in a similar way to richness in macroinvertebrates. That is, intolerant species (such as darters and Micropterus spp.) are quickly eliminated from polluted or otherwise stressed waters (Fausch et al. 1990).

\section{Centrarchidae Reproductive Life History}

The impressive adaptability of centrarchids allows multiple sympatric species to feed and spawn in proximate areas of lakes and rivers. Bluegill (Lepomis macrochirus) and green sunfish 
(L. cyanellus) occupied entirely separate habitat as adults when placed together in experimental ponds (although younger cohorts often coexisted) (Werner \& Hall 1977). The green sunfish resided in the dense vegetation near shore, where they fed mainly on macroinvertebrates such as Odonate larvae. Bluegill retreated to deeper waters, and became suspension-feeders. However, in ponds lacking green sunfish (and therefore free of interspecific competition), bluegill will preferentially occupy the vegetation near shore (Werner \& Hall 1977). The increased abundance of prey species and protection from predators among vegetation is likely responsible for the avoidance of deeper water (Mittelbach 1984).

Areas of lakes and rivers rich in gastropods are largely dominated by pumpkinseed (Lepomis gibbosus), whose molariform pharyngeal teeth allow them to crush the shells of mollusks. Bluegill lack this capacity, but possess fine gill-rakers which are ideal for Daphniarich habitat (Mittelbach 1984). However, the small prey items taken by bluegill also comprise the main prey of younger centrarchids, which then must compete with the bluegill for this resource. This may be the reason for the greater abundances of bluegill compared to other sympatric centrarchids in certain bodies of water (Werner \& Hall 1979). Centrarchids all require similar habitat in which to nest. Therefore, during spawning sympatric species may avoid competition for nest sites temporally, rather than spatially (Breder 1936).

During the winter months, centrarchids enter a state of semi-hibernation (Breder 1936). When water temperatures reach appropriate levels, the fish emerge from torpor and often immediately initiate nest construction. Smallmouth bass (Micropterus dolomieu) in Lake Opeongo, Ontario began nesting when temperatures reached $15^{\circ} \mathrm{C}$ (Ridgway et al. 1991), whereas rock bass (Ambloplites rupestris) in Lake Opinicon, Ontario began at about $21^{\circ} \mathrm{C}$ (Gross \& Nowell 1980). Bluegill and pumpkinseed in Lake Opinicon were first found occupying nests 
at $19^{\circ} \mathrm{C}$ (Garvey et al. 2002), and in New York, Pennsylvania, and Virginia redbreast sunfish (Lepomis auritus) began nesting at $20^{\circ} \mathrm{C}$ (Breder 1936; Helfrich et al. 1991).

Temperature was slightly less significant as a spawning-season indicator in rock bass dwelling in the Middle Thames River, Ontario (Noltie \& Keenleyside 1987). The rock bass began nest construction by the beginning of May in two subsequent years, despite inconsistent water temperatures. Temperature data also suggests that rock bass, if not other centrarchids, initiate reproduction at slightly lower temperatures in rivers than in lakes.

Male size may also play a role in reproductive timing. That is, larger individuals begin nest construction earlier than do smaller individuals of the same species. This has been observed in rock bass and smallmouth bass, among other centrarchids (Danylchuk \& Fox 1996). It is widely believed that this disparity is caused by the superior energy-reserves of larger fish emerging from winter torpor (Ridgway et al. 1991).

The males of all centrarchid species construct circular nest-depressions by vigorous fanning of the caudal fin. Each nest is 2 to $6 \mathrm{~cm}$ deep, about twice the diameter of its constructor (Breder 1936; Danylchuk \& Fox 1996), and takes about 2 days to complete (Jennings 1991). Large and fine sediments, vegetation, and other "impurities" are actively removed from the nest, by mouth and by fin-undulation, throughout the spawning bout (Breder 1936; Thorp 1988). Nest sites are chosen based on a large number of environmental variables. It appears that the specific variables of importance change with species and system type (rivers, lakes, etc.) (Breder 1936; Helfrich et al. 1991).

\section{Centrarchidae Nest Site Selection}

Redbreast sunfish in 11 Virginia streams nested in areas distinct from non-nested areas based on water velocity, depth, and proximity to cover objects. Depth at nests averaged $64 \mathrm{~cm}$ 
while average depth throughout the streams was $84 \mathrm{~cm}$. Water temperature was not significantly different between nested and non-nested areas. Substrate type percentages were greatly altered by nesting males, which eliminated most or all particles $>16 \mathrm{~mm}$ and $<0.51 \mathrm{~mm}$. Intermediatesized substrate types averaged 29\% before nesting, and $80 \%$ afterwards. Altering the substrate composition to this degree appears to be necessary, as the successful nesting of bluegill and redbreast sunfish is correlated with the proportion of intermediate-sized particles (Helfrich et al. 1991).

Many possible factors were considered for the nesting habits of a population of longear sunfish (L. megalotis) in the Middle Thames River. Discriminant function analysis was used to isolate only those variables that appeared to affect nest site selection. Depth and current alone adequately separated nested and non-nested habitat, although sand-gravel substrate was usually chosen over silt-cobble substrate (Bietz 1981). Longear sunfish in Jordan Creek, Illinois were largely colonial, and therefore selected for proximity to other longear sunfish nests (Jennings \& Philipp 1992). Dupuis and Keenleyside (1988) determined that nesting day within a bout, the size of the nesting colony, and centrality within the colony were correlated with nest success more so than other variables. Concrete blocks, placed in Jordan Creek as in-stream cover, attracted nesting longear sunfish, although as many males nested beside the blocks as behind them (Jennings 1991). Upstream cover, offering protection from current, was found to be important to longear sunfish nesting in the main stem channel of the Current and James Fork Rivers, Missouri (Mueller 1980).

Pumpkinseed, another colony-forming species, demonstrated selection for nest sites in the shadow of underwater objects in Pines Lake, New Jersey (Breder 1936). This behavior was most apparent in shallow waters, where $100 \%$ of nests were adjacent to rocks or logs, and 
gradually disappeared as depth increased. Pumpkinseed also preferred firm, small substrate material when given a choice (Danylchuk \& Fox 1996). Other studies have not observed proximity to cover to be as important as sunlight in determining nest site location. Specifically, warmer areas (those that are largely sun-struck and relatively shallow) were preferentially selected (Miller 1963). Pumpkinseed in Ranger Lake, Ontario only nested in water $20-110 \mathrm{~cm}$ in depth (Popiel et al. 1996). Redbreast sunfish and pumpkinseed in warm streams in New York nested exclusively just-downstream from large rocks, presumably to protect from the swift current (Breder 1936).

During a partial drainage of Wampus pond, New York in 1935 (which eliminated the gravel-sand habitat and left only a heavily-silted bottom), redbreast sunfish, pumpkinseed, and smallmouth bass attempted to nest in substrate which was never nested in the past. The males dug huge pits in the silt, apparently searching for harder substrate that would support the dense centrarchid eggs (Breder 1936). Indeed, some species appear to only require solid substrate on which to nest, and may even forgo nest building. Breder (1936) cites Wiebe (1935), who observed largemouth bass nesting on submerged roots and concrete. The fanning behavior typical of excavation was still performed, but obviously had no effect.

Rock bass in Lake Opinicon selected nest sites based mainly on proximity to other bass nests. Bass nesting $\leq 5 \mathrm{~m}$ from another nest constituted $69 \%$ of the sample population. Underwater obstructions and nests of other centrarchid species were neither avoided nor selected (Gross \& Nowell 1980). Rock bass in the Middle Thames River preferred upstream obstructions, which were energetically profitable for individuals in flowing water. Furthermore, all nests were located in a relatively small, homogeneous section of the river, furthering the case for intensive 
site selection. No selection for proximity to other nests was observed (Noltie \& Keenleyside 1987).

Smallmouth bass spawning in Indian Creek, Ohio selected water velocity and proximity to cover objects over other environmental variables. Specifically, $90 \%$ of nests were located in water with little discernable current, and all nests were located beneath overhead cover. This was likely a response to the frequent episodes of flooding observed in the creek, which would destroy nests located near the thalweg. Although the largest nests (constructed by the largest males) were never clustered together, smaller nests were often found in loose colonies, especially in the larger pools (Winemiller \& Taylor 1982).

Coloniality, as mentioned above, contributes to the ultimate locations of nests in a number of species. Bluegill in particular are known for their tendency to form dense colonies with high spawning synchrony. In Lake Opinicon, Ontario 3,059 spawning males formed 106 colonies during the season, resulting in an average of 29 nests per colony (Cargnelli \& Neff 2006). The frequency of brood predation by snails and Ameiurus catfish was $>3$ times higher in the peripheral nests of bluegill colonies than in central nests in Lake Opinicon, Ontario. Brood predation on solitary nests was greater still. This is believed to be caused by a screening effect, where brood predators simply attack the first nest they encounter in a colony, as well as by cumulative defense, where the overlapping territories of a number of males causes a mobbing of predators (Gross \& MacMillan 1981).

Aquatic fungi, such as Saprolengia, are also responsible for large brood losses in sunfish. Fungal infection is much more common in solitary nests than in colony nests (Cote \& Gross 1993). All bluegill nests in Lake Opinicon in 1993 contained infected eggs, but solitary nests had twice the number (Cote \& Gross 1993). This is believed to be related to the need for solitary 
males to expend more time and energy on predator-chasing, which leaves less time for eggfanning. Egg-fanning, a behavior performed by gentle pectoral fin undulations, prevents the eggs from suffocating under silt, but also greatly decreases the spread of infection in nests (Breder 1936; Cote \& Gross 1993). Saprolengia does not spread from nest to nest (Cote \& Gross 1993).

Colonies of longear sunfish regularly form around one or two larger males; that is, the majority of the colony is made up of physically inferior individuals (Jennings \& Philipp 1992). Cuckoldry, a behavior where a male sneaks into another male's nest to fertilize freshly-laid eggs, is common in longear and other centrarchids (Jennings \& Philipp 1992; Neff 2003). Sunfish males are known to chase females from their nests when they have already spawned with another female. Therefore, females attracted by the larger males, but rejected, may swim into the nests of smaller peripheral males and spawn there (Gross \& Nowell 1980; Jennings \& Philipp 1992). The large males seem to tolerate the presence of the smaller males due to the advantages mentioned above (such as predator mobbing), as well as the energy that would be required to relocate.

\section{Centrarchidae Spawning Bouts and Nest Reuse}

A number of studies have indicated that the prolonged spawning season of centrarchids is largely caused by the tendency for males to spawn multiple times in a season. Of 129 captured and marked male pumpkinseed in Little Round Lake, Ontario, 3 of these were found on new nests sites later in the season (Danylchuk \& Fox 1996). Of the 53\% of bluegill in Lake Opinicon, Ontario that nested multiple times, $83 \%$ nested twice and 17\% nested three times (Cargnelli \& Neff 2006). About $19 \%$ of the male rock bass in Lake Opinicon spawned twice (Gross \& Nowell 1980). Bluegill in Lake Opinicon complete 3 to 6 nesting cycles each year (Cote \& Gross 1993). In the Middle Thames River, rock bass frequently nested multiple times within a season; larger and older males were more likely to renest than smaller or younger males (Noltie \& Keenleyside 1986). 
The benefits of spawning multiple times in a season are largely due to the inconsistent environmental conditions of freshwater habitats, especially streams and rivers. This form of "bethedging" is found in pumpkinseed due to fluctuating zooplankton (the main prey of sunfish fry) densities (Fox \& Crivelli 1998). The frequency of major flooding events, which completely destroyed rock bass nests in the Middle Thames, also necessitated multiple broods (Noltie \& Keenleyside 1986). Similar cases of flooding were observed in Indian Creek, Ohio (Winemiller $\&$ Taylor 1982).

The period between spawning bouts is believed to correspond to the time necessary for an additional clutch of eggs to ripen within a female centrarchid. Young from the previous spawning bout always hatched and left the nest before the females again developed mature eggs (Taylor 1978). This provides a partial explanation for the high degree of spawning synchrony found in solitary-nesting species such as the redbreast sunfish.

Most species of centrarchid feed minimally while guarding their nest sites, but nevertheless a certain amount of energy intake is required. Centrarchids failing to meet this requirement have been observed to cannibalize part or all of their brood. Cannibalism is also common when the males suspect cuckoldry (Neff 2003). In regions where redbreast sunfish and dusky shiners (Notropis cummingsae) are sympatric, a parasitic relation has evolved where the shiners devour part of the sunfish's brood, and supplant the eaten eggs with their own (Fletcher 1993). Snails, such as those found in Lake Opinicon, and Ameiurus spp. may also destroy a brood, and force additional spawning bouts (Gross \& MacMillan 1981).

Studies of sunfish in New York and The Middle Thames River suggest that earlyspawning males are more successful than later spawners (Breder 1936; Noltie \& Keenleyside 1986). This may be attributable to the higher oxygen level in colder water, which places lesser 
nest-fanning demands on the males (Breder 1936). Because larger males are more likely to spawn earlier than smaller males, the fitness advantages of the parentals may also increase brood survivorship (Noltie \& Keenleyside 1987). Other studies have failed to detect any survival advantage from early breeding (Garvey et al. 2002).

The first spawning bout in a season is actually one of the worst times to spawn in regards to reproductive success for centrarchids in Lake Opinicon, and is only used to maximize the number of bouts possible in a season (Cargnelli \& Neff 2006). In years where environmental disturbances are infrequent, the smaller, later-spawning males have an advantage. This is due to the extraordinary amount of energy required for nesting behavior in centrarchids (Garvey et al. 2002). Lower brood survivorship in early nesters may also be linked to the abundance of certain fungal infections following periods of low temperature in Pickerel Lake, Michigan (Taylor 1978).

Given the energy required to complete nests, and then to guard the eggs and fry for up to a few weeks, it seems logical that centrarchids spawning after the first bout (including those spawning for the second or third time) should seek out abandoned nests to reuse. Indeed, this behavior has been witnessed by a number of different researchers (Breder 1936; Gross \& Nowell 1980; Thorp 1988; Jennings 1991), though always only mentioned in passing.

This behavior was first apparent by the size discrepancy between some centrarchid individuals and their nests in Llewellyn Lake, New Jersey. That is, the nests were much larger than the 2:1 ratio mentioned above (Breder 1936). Specifically, in Llewellyn Lake, redbreast sunfish were seen to occupy the abandoned nests of largemouth bass (Micropterus salmoides). Rather than construct a new nest within the larger nest, the sunfish simply swept the bass nest clean of silt and debris. However, Llewellyn Lake may be a biased site. A high degree of angling 
occurred on the lake in the spring, potentially pulling nesting males off of established sites prematurely. Pines Lake, New Jersey by contrast was fished much less frequency, and nest reuse was rarer (Breder 1936).

Although pumpkinseed and redbreast sunfish in New York commonly constructed new nests after largemouth bass ended their first spawning bout, certain nests were sequentially occupied by these three species (Thorp 1988). Rock bass in Lake Opinicon claimed the (relatively small) abandoned nests of Lepomis spp., swept them free of debris, and began to spawn. Three such renesting events involved rock bass occupying the nests of two pumpkinseed and one pumpkinseed-bluegill hybrid. No brood was raised successfully in these nests prior to the appearance of the rock bass, and the one rock bass nest (of the three) which failed was later reused by a pumpkinseed that did spawn successfully (Gross \& Nowell 1980). This suggests that a nest which successfully yields a brood may become less attractive, or effective, to later spawners.

Occasionally, a single male has been seen to exhibit mild nest-site fidelity. The laterspawning pumpkinseed mentioned above (Gross \& Nowell 1980) raised two successful broods on the same site, a site which up to that point had yielded no fry. Pumpkinseed have been observed to raise two broods on the same site, one in mid-July and the other in early-August (Breder 1936). Renesting male pumpkinseed in Jordan Creek are more likely to reuse the same nest site than to spawn on a new site, regardless of whether or not the new site was previously nested (Jennings 1991).

Nest-site reuse is relatively common in species with energetically demanding nesting behavior. Brook trout (Salvelinus fontinalis) and brown tout (Salmo trutta), for instance, preferentially superimpose their redds on preexisting ones. This behavior removes the fertilized 
eggs of competing trout, but also reduces the amount of sediment that needs to be swept away (Essington et al. 1998). Cavity-building and nesting birds, such as woodpeckers, also show signs of nest-site fidelity. Secondary cavity-nesters, such as Poecile spp. and some waterfowl, resemble smaller sunfish using the abandoned nests of larger, more powerful bass. The difference here is that the raising of young in birds is a much more protracted endeavor, and therefore nest reuse usually does not occur until the following year. This leaves time for parasites and debris to accumulate in the abandoned nests (Aitken et al. 2002).

Similar negative influences may also affect the frequency of nest reuse in centrarchids. Fungal infections (Cote \& Gross 1993) and brood predators (Gross \& MacMillan 1981) may persist in nest sites for days after abandonment, and nesting behavior has been shown to drastically reduce the number of prey species in the vicinity of the nest (Thorp 1988). Additionally, the conditions by which colonial spawning arises in some species may make the formation of a new colony much more common than the reuse of an older colony.

A possible alternative to nest-site reuse (in which an old but currently un-nested site is adopted) is the supplanting of nesting individuals by larger or more aggressive intruders. One large male longear sunfish in Huron River, Michigan usurped an occupied nest, and then repelled the previous owner when he returned, thus securing two separate nests (Taylor 1978). Equally aggressive species, such as the redbreast sunfish (Miller 1963), may also exhibit such behavior.

\section{Centrarchidae Response to Perceived Harm}

Sunfish eggs and larvae are susceptible to aquatic predators such as snails, bullhead catfish, and crayfish (Gross \& MacMillan 1981; Dorn \& Mittelbach 2004). Fish, including shiners and bass, may also be responsible for offspring loss. In lakes with more threat of predation from these species, energy expenditure from male nest defense lowered overall nest success (Popiel et al. 1996). 
Adult centrarchids are preyed upon by a range of aquatic and terrestrial predators. When exposed to replicas of two such predators, the great blue heron (Ardea herodias) and the belted kingfisher (Ceryle alcyon), male dollar sunfish (Lepomis marginatus) in Fire Pond, South Carolina decreased time spent guarding their nests and decreased their activity levels (such as egg-fanning) while on the nests. When eggs were present, the males returned to the nests more quickly than when the nests did not contain eggs (Winkelman 1996).

Parental investment varies based on the needs and perceived value of offspring. Although nest-predation pressure by other fishes varied greatly between six sympatric centrarchid species in Lake Opinicon, Ontario, males of all species exposed to higher numbers of predation attempts devoted considerably less time to nest-tending behavior (Cooke et al. 2008). Male size also influences the magnitude of response to predation threat. In lakes near Montreal, Quebec, large pumpkinseed sunfish exposed to chemical alarm cues maintained foraging behavior longer than did small or medium-sized pumpkinseed. However, in areas of high habitat complexity (high height and density of cover objects), pumpkinseed of all size classes exhibited immediate anti-predator behavior (Golub et al. 2005).

The Current and James Fork Rivers, Missouri have extensive traffic from recreational boats. These drive longear sunfish from their nests much as predators would. Mueller (1980) found that males guarding nests located near underwater cover objects returned to their nests more quickly than did males not associated with cover objects.

Males of the common goby (Pomatoschistus microps) and three-spine stickleback (Gasterosteus aculeatus), like sunfish, expend considerable energy to construct nests and defend their offspring from predators. Nesting common gobies in a shallow bay were exposed to eelpouts (Zoarces viviparous, a potential predator). Time spent away from the nests decreased as 
the spawning season progressed, and in the presence of eggs (Magnhagen \& Vestergaard 1991). When exposed to dummy predators, male three-spine sticklebacks in British Columbia deserted their nests less often when they contained eggs. Time until return was also shorter in the presence of eggs (Pressley 1981).

\section{Study Site}

The 178-km long Cacapon River, located in the Appalachian Mountains of West Virginia's eastern panhandle, is part of the Potomac River Watershed (Cacapon Institute 2009). The Cacapon Watershed drains over 1,700 $\mathrm{km}^{2}$. Forest covers $79 \%$ of the watershed's land; $19 \%$ is agricultural and $2 \%$ is residential, barren land, or surface water. The geology of the watershed is mainly shale (> 50\%), with sandstone and limestone interspersed (Cacapon Institute 2009). In Hardy County, West Virginia the river averages an annual temperature of $23.5^{\circ} \mathrm{C}$ and a pH of 8.4. The abundance of fecal coliform bacteria (found in the intestines of livestock) in Hardy County is double that of most other reaches of the Cacapon (Constantz et al. 1995). This value indicates a high degree of agricultural land-use.

One stretch of the Cacapon River, about 500-m in length, was selected to undergo restoration (Fig. 1-3). The specific techniques were selected based on presumed effectiveness at reducing runoff and bank erosion. The restoration stretch was chosen based on cumulative scores from a rating system modified from Strager et al. (2011) (Appendix 1a). Mr. Joseph Frye owns the right bank of the restoration stretch, and Mr. Jack Rudolph owns the left bank.

Multiple eroding sections of each bank were excavated to create gentle $\left(45^{\circ}\right)$ slopes and a small artificial floodplain (Fig. 4). The newly constructed banks were stabilized with erosioncontrol biotextile fabric fastened with staples. Several biologs, stabilized with wooden stakes, 
were positioned across the restructured banks for additional erosive protection and sediment collection.

Woody vegetation and warm season grasses were planted within two zones: zone a, extending from the water to the top of the bank; and zone b, above the excavated bank (Fig. 5). Zone a was planted with seven species of woody vegetation (Table 1). Total plantings within this zone covered 0.19 ha of the Frye bank (265 total tree and shrub plantings) and 0.15 ha of the Rudolph bank (205 total plantings). Zone b on both banks was planted with 13 species (Table 2). Total plantings within this zone covered 0.83 ha of the Frye bank (882 total plantings) and 0.35 ha of the Rudolph bank (378 total plantings). An additional 0.24 ha of switchgrass (Panicum virgatum, a warm season grass) were planted in a section of the Frye bank. Vegetation was obtained from the following nurseries: Pennsylvania Game Commission (Harrisburg, Pennsylvania), Pinelands Nursery, Inc. (Toano, Virginia); Carino Nurseries (Indiana, Pennsylvania); Lawyer Nursery, Inc. (Plains, Montana); Pikes Peak Nursery (Penn Run, Pennsylvania); and Musser Forests, Inc. (Indiana, Pennsylvania).

The planting zones were protected from cattle with electrical fencing, installed by Bland Fencing LLC (Petersburg, West Virginia). Two parallel lines were laid to also deter white-tailed deer (Odocoileus virginianus) grazing. The Frye bank plantings were lined with $956 \mathrm{~m}$ of fencing reaching $15 \mathrm{~m}$ from the river bank, and the Rudolph banks were lined with $467 \mathrm{~m}$ of fencing $11 \mathrm{~m}$ from the bank. Gates were installed to allow personal and vehicle access to the planting zones.

During the fall of 2010, efforts were made to remove invasive species (specifically barberry, Berberis thunbergii; autumn olive, Elaeagnus umbellate; and multiflora rose, Rosa multiflora) from the planting zones of the Frye Bank using a "hack 'n' squirt" method with 
Roundup brand herbicide (Monsanto Co., St. Louis, Missouri). Roundup is a broad-spectrum herbicide, which uses the active ingredient Glyphosate.

Nine log vanes were positioned along the restoration stretch (six on the Frye bank and three on the Rudolph bank) to direct water away from the restructured banks, and were stabilized with boulders and gravel excavated from within the river (Fig. 6). The structures were further anchored by cabling the log vanes to buried logs (Fig. 7). Water flow over these vanes quickly established scour pools on the downstream sides of the structures.

The restoration stretch was flanked by four additional stretches (two upstream and two downstream), each about equal in length to the restoration stretch. A map of these stretches was created using AcrGIS 10.0 (Esri 2010) (Fig. 8). Two of the stretches were in need of restoration (control stretches), based on the rating system mentioned above, but restoration was not conducted at these stretches. One of these was positioned $<4 \mathrm{~km}$ upstream of the restoration stretch (Fig. 9), and one $<4 \mathrm{~km}$ downstream (Fig. 10). The other two stretches were reference stretches. These had largely stable banks, substantial riparian buffers, and scored low on the rating system. One was $<4 \mathrm{~km}$ upstream from the restoration stretch (Fig. 11), while the other was $<4$ km downstream (Fig. 12).

One stretch of the Cacapon River, located between $39^{\circ} 05^{\prime} 33^{\prime \prime} \mathrm{N}, 78^{\circ} 35^{\prime} 12^{\prime \prime} \mathrm{W}$ and $39^{\circ} 07^{\prime} 53^{\prime \prime} \mathrm{N}, 78^{\circ} 32^{\prime} 35^{\prime \prime} \mathrm{W}$, was surveyed for centrarchid nests. A map of this stretch was created using AcrGIS 10.0 (Esri 2010) (Fig. 13). These coordinates correspond to a public put-in located just north of Wardensville and a take-out point on a privately-owned road on Mr. Sandy White's property. This stretch is about $8.53-\mathrm{km}$ in length. It is mainly located within Hardy County, West Virginia with a portion in Hampshire County, WV. 
The stretch has a wide range of microhabitats, and transitions frequently between riffleand pool-dominated sections. Seasonal low-flows (such as those caused by drought during 2010) may prevent centrarchids from migrating between some sections, although few riffles are true natural barriers during even these flow conditions. Only small sections of the stretch support submerged aquatic vegetation; most have bare substrate. During late summer in 2009 and 2010 a large algal bloom spread downstream from these vegetation beds, in some cases smothering centrarchid nesting areas. Large woody debris increased greatly in abundance from 2009 to 2010, creating new nesting habitat for species that preferentially nest near cover objects. These were all personal observations by the author (S. M. Selego) during 2009 and 2010.

\section{LITERATURE CITED}

Adams, S. M., W. R. Hill, M. J. Peterson, M. G. Ryon, J. G. Smith, and A. J. Stewart. 2002. Assessing recovery in a stream ecosystem: applying multiple chemical and biological endpoints. Ecological Applications 12:1510-1527.

Aitken, K. E. H., K. L. Weibe, and K. Martin. 2002. Nest-site reuse patterns for a cavity-nesting bird community in interior British Columbia. The Auk 119:391-402.

Alexander, G. G., and J. D. Allan. 2007. Ecological success in stream restoration: case studies from the Midwestern United States. Environmental Management 40:245-255.

Angermeier, P. L., and J. R. Karr. 1986. Applying an index of biotic integrity based on streamfish communities: considerations in sampling and interpretation. North American Journal of Fisheries Management 6:418-429.

Angermeier, P. L., and M. R. Winston. 1998. Local vs. regional influences on local diversity in stream fish communities of Virginia. Ecology 79:911-927. 
Arthington, A. H., R. J. Naiman, M. E. McClain, and C. Nilsson. 2010. Preserving the biodiversity and ecological services of rivers: new challenges and research opportunities. Freshwater Biology 55:1-16.

Barbour, M. T., J. Gerritsen, G. E. Griffith, R. Frydenborg, E. McCarron, J. S. White, and M. L. Bastian. 1996. A framework for biological criteria for Florida streams using benthic macroinvertebrates. Journal of the North American Benthological Society 15:185-211.

Barbour, M. T., J. Gerritsen, B. D. Snyder, and J. B. Stribling. 1999. Rapid bioassessment protocols for use in streams and wadeable rivers: periphyton, benthic macroinvertebrates and fish, second edition. EPA 841-B-99-002. U.S. Environmental Protection Agency; Office of Water; Washington, D.C.

Berkman, H. E, and C. F. Rabeni. 1986. Biomonitors of stream quality in agricultural areas: fish versus invertebrates. Environmental Management 10:413-419.

Bietz, B. F. 1981. Habitat availability, social attraction and nest distribution patterns in longear sunfish (Lepomis megalotis peltastes). Environmental Biology of Fishes 6:193-200.

Breder, C. M. 1936. The reproductive habits of the North American sunfishes (family Centrarchidae). Zoologica 21:1-48.

Cargnelli, L. M., and B. D. Neff. 2006. Condition-dependent nesting in bluegill sunfish Lepomis macrochirus. Journal of Animal Ecology 75:627-633.

Chapman, M. G. 1999. Improving sampling design for measuring restoration in aquatic habitats. Journal of Aquatic Ecosystem Stress and Recovery 6:235-251.

Colgan, P. W. 1988. Dynamics of nest defense by male centrarchid fish. Behavioural Processes $17: 17-26$. 
Constantz, G., N. Ailes, and D. Malakoff. 1995. Portrait of a river: the ecological baseline of the Cacapon River. Pine Cabin Run Ecological Laboratory, High View, West Virginia.

Cooke, S. J., P. J. Weatherhead, D. H. Wahl, D. P. Philipp. 2008. Parental care in response to natural variation in nest predation pressure in six sunfish (Centrarchidae: Teleostei) species. Ecology of Freshwater Fish 17:628-638.

Cote, I. M., and M. R. Gross. 1993. Reduced disease in offspring: a benefit of coloniality in sunfish. Behavioral Ecology and Sociobiology 33:269-274.

Daniels, R. A., K. Riva-Murray, D. B. Halliwell, D. L. Vana-Miller, and M. D. Bilger. 2002. An index of biological integrity for northern mid-Atlantic slope drainages. Transactions of the American Fisheries Society 131:1044-1060.

Danylchuk, A. J., and M. G. Fox. 1996. Size- and age-related variation in the seasonal timing of nesting activity, nest characteristics, and female choice of parental male pumpkinseed sunfish (Lepomis gibbosus). Canadian Journal of Zoology 74:1834-1840.

Dorn, N. J., and G. G. Mittelbach. 2004. Effects of a native crayfish (Orconectes virilis) on the reproductive success and nesting behavior of sunfish (Lepomis spp.). Canadian Journal of Fisheries and Aquatic Sciences 61:2135-2143.

Dupuis, H. M. C., and M. H. A. Keenleyside. 1988. Reproductive success of nesting male longear sunfish (Lepomis megalotis peltases). Behavioral Ecology and Sociobiology 23:109-116.

Essington, T. E., P. W. Sorensen, and D. G. Paron. 1998. High rate of redd superimposition by brook trout (Salvelinus fontinalis) and brown trout (Salmo trutta) in a Minnesota stream cannot be explained by habitat availability alone. Canadian Journal of Fisheries and Aquatic Sciences 55:2310-2316. 
Fausch, K. D., J. Lyons, J. R. Karr, and P. L. Angermeier. 1990. Fish communities as indicators of biological degradation. American Fisheries Society Symposium 8:123-144.

Fletcher, D. E. 1993. Nest association of dusky shiners (Notropis commingsae) and redbreast sunfish (Lepomis auritus), a potentially parasitic relationship. Copeia 1993:159-167.

Fox, M. G., and A. J. Crivelli. 1998. Body size and reproductive allocation in a multiple spawning centrarchid. Canadian Journal of Fisheries and Aquatic Sciences 55:737-748.

Garvey, J. E., T. P. Herra, and W. C. Leggett. 2002. Protracted reproduction in sunfish: the temporal dimension in fish recruitment revisited. Ecological Applications 12:194-205.

Golub, J. L., V. Vermette, and G. E. Brown. 2005. Response to conspecific and heterospecific alarm cues by pumpkinseed in simple and complex habitats: field verification of an ontogenetic shift. Journal of Fish Biology 66:1073-1081.

Gray, E. S. R. M. Ross, and R. M. Bennett. 2005. Bioassessment of fish communities of the upper Delaware River. Northeastern Naturalist 12:203-216.

Gross, M. R., and A. M. MacMillan. 1981. Predation and the evolution of colonial nesting in bluegill sunfish (Lepomis macrochirus). Behavioral Ecology and Sociobiology 8:163174.

Gross, M. R., and W. A. Nowell. 1980. The reproductive biology of rock bass, Ambloplites rupestris (Centrarchidae), in Lake Opinicon, Ontario. Copeia 1980:482-494.

Helfrich, L. A., K. W. Nutt, and D. L. Weigmann. 1991. Habitat selection by spawning redbreast sunfish in Virginia streams. Rivers 2:138-147.

Jennings, M. J. 1991. Sexual selection, reproductive strategies, and genetic variation in longear sunfish (Lepomis megalotis). Thesis, University of Illinois, Urbana-Champaign. 
Jennings, M. J., and D. P. Philipp. 1992. Female choice and male competition in longear sunfish. Behavioral Ecology 3:84-94.

Johnson, P. A., R. D. Hey, E. R. Brown, and D. L. Rosgen. 2002. Stream restoration in the vicinity of bridges. Journal of the American Water Resources Association 38:55-67.

Kerans, B. L., and J. R. Karr. 1994. A benthic index of biotic integrity (B-IBI) for rivers of Tennessee Valley. Ecological Applications 4:768-785.

Keystone Stream Team. 2003. Guidelines for Natural Stream Channel Design for Pennsylvania Waterways. Alliance for Chesapeake Bay and Pennsylvania Department of Environmental Protection, Williamsport, Pennsylvania.

Kondolf, G. M. 1995. Five elements for effective evaluation of stream restoration. Restoration Ecology 3:133-136.

Kondolf, G. M., and E. R. Micheli. 1995. Evaluating stream restoration projects. Environmental Management 19:1-15.

Kondolf, G. M., M. W. Smeltzer, and S. F. Railsback. 2001. Design and performance of a channel reconstruction project in a coastal California gravel-bed stream. Environmental Management 28:761-776.

Larimore, R. W. 1961. Fish population and electrofishing success in a warm-water stream. The Journal of Wildlife Management 25:1-12.

Lenat, D. R. 1984. Agriculture and stream water quality: a biological evaluation of erosion control practices. Environmental Management 8:333-344.

Lenat, D. R. 1988. Water quality assessment of streams using a qualitative collection method for benthic macroinvertebrates. Journal of the North American Benthological Society 7:222233. 
Lepori, F., D. Palm, E. Brannas, and B. Malmqvist. 2005. Does restoration of structural heterogeneity in streams enhance fish and macroinvertebrate diversity? Ecological Applications 15:2060-2071.

Magnhagen, C., and K. Vestergaard. 1991. Risk taking in relation to reproductive investments and future reproductive opportunities: field experiments on nest-guarding common gobies, Pomatoschistus microps. Behavioral Ecology 2:351-359.

Miller, C. H. 1963. The behavior of the pumpkinseed sunfish, Lepomis gibbosus (Linnaeus), with notes on the behavior of other species of Lepomis and the pigmy sunfish, Elassoma evergladei. Behaviour 22:88-151.

Miller, S. W., P. Budy, and J. C. Schmidt. 2010. Quantifying macroinvertebrate responses to instream habitat restoration: applications of meta-analysis to river restoration. Restoration Ecology 18:8-19.

Mittelbach, G. G. 1984. Predation and resource partitioning in two sunfishes (Centrarchidae). Ecology 65:499-513.

Moerke, A. H., Gerard, K. J., Latimore, J. A., Hellenthal, R. A., and Lamberti, G. A. 2004. Restoration of an Indiana, USA, stream: Bridging the gap between basic and applied lotic ecology. Journal of the North American Benthological Society 23:647-660.

Mueller, G. 1980. Effects of recreational river traffic on nest defense by longear sunfish. Transactions of the American Fisheries Society 109:248-251.

Muotka, T., R. Paavola, A. Haapala, M. Novikmee, and P. Laasonen. 2001. Long-term recovery of stream habitat structure and benthic invertebrate communities from in-stream restoration. Biological Conservation 105:243-253. 
Nagle, G. 2007. Evaluating ‘natural channel design’ stream projects. Hydrological Processes 21:2539-2545.

Neff, B. D. 2003. Paternity and condition affect cannibalistic behavior in nest-tending bluegill sunfish. Behavioral Ecology and Sociobiology 54:377-384.

Noltie, D. B., and M. H. A. Keenleyside. 1986. Correlates of reproductive success in streamdwelling male rock bass, Ambloplites rupestris (Centrarchidae). Environmental Biology of Fishes 17:61-70.

Noltie, D. B., and M. H. A. Keenleyside. 1987. Breeding ecology, nest characteristics, and nestsite selection of stream- and lake-dwelling rock bass, Ambloplites rupestris (Rafinesque). Canadian Journal of Zoology 65:379-390.

Opperman, J. J., and A. M. Merenlender. 2004. The effectiveness of riparian restoration for improving instream fish habitat in four hardwood-dominated California streams. North American Journal of Fisheries Management 24:822-834.

Osmundson, D. B., R. J. Ryel, V. L. Lamarra, and J. Pitlick. 2002. Flow-sediment-biota relations: implications for river regulation effects on native fish abundance. Ecological Applications 12:1719-1739.

Popiel, S. A., A. Perez-Fuentetaja, D. J. McQueen, and N. C. Collins. 1996. Determinants of nesting success in the pumpkinseed (Lepomis gibbosus): a comparison of two populations under different risks from predation. Copeia 1996:649-656.

Pressley, P. H. 1981. Parental effort and the evolution of nest-guarding tactics in the threespine stickleback, Gasterosteus aculeatus L. Evolution 35:282-295. 
Radspinner, R. R., P. Diplas, A. F. Lightbody, and F. Sotiropoulos. 2010. River training and ecological enhancement potential using in-stream structures. Journal of Hydraulic Engineering 136:967-980.

Ridgway, M. S., B. J. Shuter, and E. E. Post. 1991. The relative influence of body size and territorial behavior on nesting asynchrony in male smallmouth bass, Micropterus dolomieu (Pisces: Centrarchidae). Journal of Animal Ecology 60:665-681.

Rosgen, D. L. 1998. The Reference Reach-A Blueprint for Natural Channel Design. In: Proceedings of American Society of Civil Engineers, Restoration of Wetlands and Rivers, Denver, Colorado.

Selvakumar, A., T. P. O’Connor, and S. D. Struck. 2010. Role of stream restoration on improving benthic macroinvertebrates and in-stream water quality in an urban watershed: case study. Journal of Environmental Engineering 136:127-139.

Spanhoff, B., and J. Arle. 2007. Setting attainable goals of stream habitat restoration from a macroinvertebrate view. Restoration Ecology 15:317-320.

Sweeney, B. W., T. L. Bott, J. K. Jackson, L. A. Kaplan, J. D. Newbold, L. J. Standley, W. C. Hession, R. J. Horwitz, and M. G. Wolman. 2004. Riparian deforestation, stream narrowing, and loss of stream ecosystem services. Proceedings of the National Academy of Sciences of the United States of America 101:14132-14137.

Strager, M.P., J.T. Anderson, J.D. Osbourne, and R. Fortney. 2011. A three-tiered framework to select, prioritize, and evaluate potential wetland and stream mitigation banking sites. Wetlands Ecology and Management 19:1-18.

Taylor, J. N. 1978. Behavioral components of reproductive success in male sunfishes of the genus Lepomis. Dissertation, The University of Michigan, Ann Arbor. 
Teels, B. M., C. A. Rewa, and J. Myers. 2006. Aquatic condition response to riparian buffer establishment. Wildlife Society Bulletin 34:927-935.

Thorp, J. H. 1988. Patches and the responses of lake benthos to sunfish nest-building. Oecologia 76:168-174.

Werner, E. E., and D. J. Hall. 1975. Niche shifts in sunfishes: experimental evidence and significance. Science 191:404-406.

Werner, E. E., and D. J. Hall. 1977. Competition and habitat shift in two sunfishes (Centrarchidae). Ecology 58:869-876.

Werner, E. E., and D. J. Hall. 1979. Foraging efficiency and habitat switching in competing sunfishes. Ecology 60:256-264.

Winemiller, K. O., and D. H. Taylor. 1982. Smallmouth bass nesting behavior and nest site selection in a small Ohio stream. Ohio Journal of Science 82:266-273.

Winkelman, D. L. 1996. Reproduction under predatory threat: trade-offs between nest guarding and predator avoidance in male dollar sunfish (Lepomis marginatus). Copeia 1996:845851. 
Table 1: Plantings in zone A (water edge to top of bank) of the Cacapon River, West Virginia, USA restoration stretch. Woody vegetation species were planted to establish a riparian buffer and reduce erosion on the newly constructed banks.

\begin{tabular}{lccccc}
\hline & \multicolumn{2}{c}{ No. } & planted & & \\
\cline { 2 - 3 } Species- Zone A (Engineered) & Frye & Rudolph & Tree/ Shrub & Pollinator species \\
\hline Sycamore (Platanus occidentalis) & 25 & 0 & Tree & no \\
Cottonwood (Populus deltoides) & 26 & 24 & Tree & no \\
River birch (Betula nigra) & 0 & 0 & Tree & no \\
Elderberry (Sambucus canadensis) & 50 & 50 & Shrub & yes \\
Black Willow (Salix nigra) & 0 & 25 & Tree & no \\
Silky cornel (Cornus amomum) & 25 & 25 & Shrub & yes \\
Streamside alder (Alnus serrulata) & 40 & 30 & Shrub & no \\
Buttonbush (Cephalanthus occidentalis) & 99 & 51 & Shrub & yes \\
Total & 265 & 205 & & \\
\hline
\end{tabular}


Table 2: Plantings in zone B (above bank) of the Cacapon River, West Virginia, USA restoration stretch. Woody vegetation species were planted to establish a riparian buffer and reduce sedimentation and pollutant runoff from the surrounding pastureland. The 'P?' column indicates whether the tree or shrub is a pollinator species.

\begin{tabular}{lccccc}
\hline & No. & Planted & & \\
\cline { 2 - 4 } Species - Zone B & Frye & Rudolph & T/S & P? \\
\hline Redbud (Cercis canadensis) & 70 & 30 & Shrub & yes \\
Winterberry (Ilex verticillata) & 60 & 40 & Shrub & yes \\
Spicebush (Calycanthus floridus) & 70 & 30 & Shrub & yes \\
Serviceberry (Amelanchier leavis) & 0 & 0 & Tree & yes \\
Swamp White Oak (Quercus bicolor) & 100 & 48 & Tree & no \\
Swamp Oak (Quercus palustris) & 60 & 40 & Tree & no \\
Bailey Red Snowberry (Symphoricarpus orbiculatus) & 0 & 0 & Shrub & no \\
Nannyberry (Viburnum lentago) & 0 & 0 & Shrub & yes \\
Ninebark (Physocarpus opulifolius) & 0 & 0 & Shrub & yes \\
Shrubby St. johnswort (Hypericum prolificum) & 0 & 0 & Shrub & yes \\
Gray dogwood (Cornus racemosa) & 60 & 40 & Shrub & yes \\
Persimmon (Diospyros virginiana) & 75 & 0 & Tree & no \\
Choke cherry (Prunus virginiana) & 60 & 40 & Shrub & yes \\
Black haw (Viburnum prunifolium) & 60 & 40 & Shrub & yes \\
American basswood (Tilia americana) & 80 & 40 & Tree & yes \\
Wild plum (Prunus americana) & 50 & 0 & Shrub & yes \\
Virginia rose (Rosa virginiana) & 0 & 0 & Shrub & yes \\
Smooth arrowwood (Viburnum recognitum) & 0 & 0 & Shrub & yes \\
Rough arrowwood (Viburnum dentatum) & 68 & 32 & Shrub yes & yes \\
Black chokeberry (Aronia melanocarpa) & 0 & 0 & Shrub & yes \\
Meadowsweet (Spiraea alba) & 0 & 0 & Shrub & yes \\
Steeplebush (Spiraea tomentosa) & 0 & 0 & Shrub & yes \\
Fringetree (Chionanthus virginicus) & 0 & 0 & Shrub & yes \\
Wild crabapple (Malus coronaria var. coronaria) & 67 & 0 & Shrub yes & yes \\
Hawthornes (Crataegus spp.) & 0 & 0 & Tree & yes \\
Total & 880 & 380 & & \\
\hline & & & &
\end{tabular}




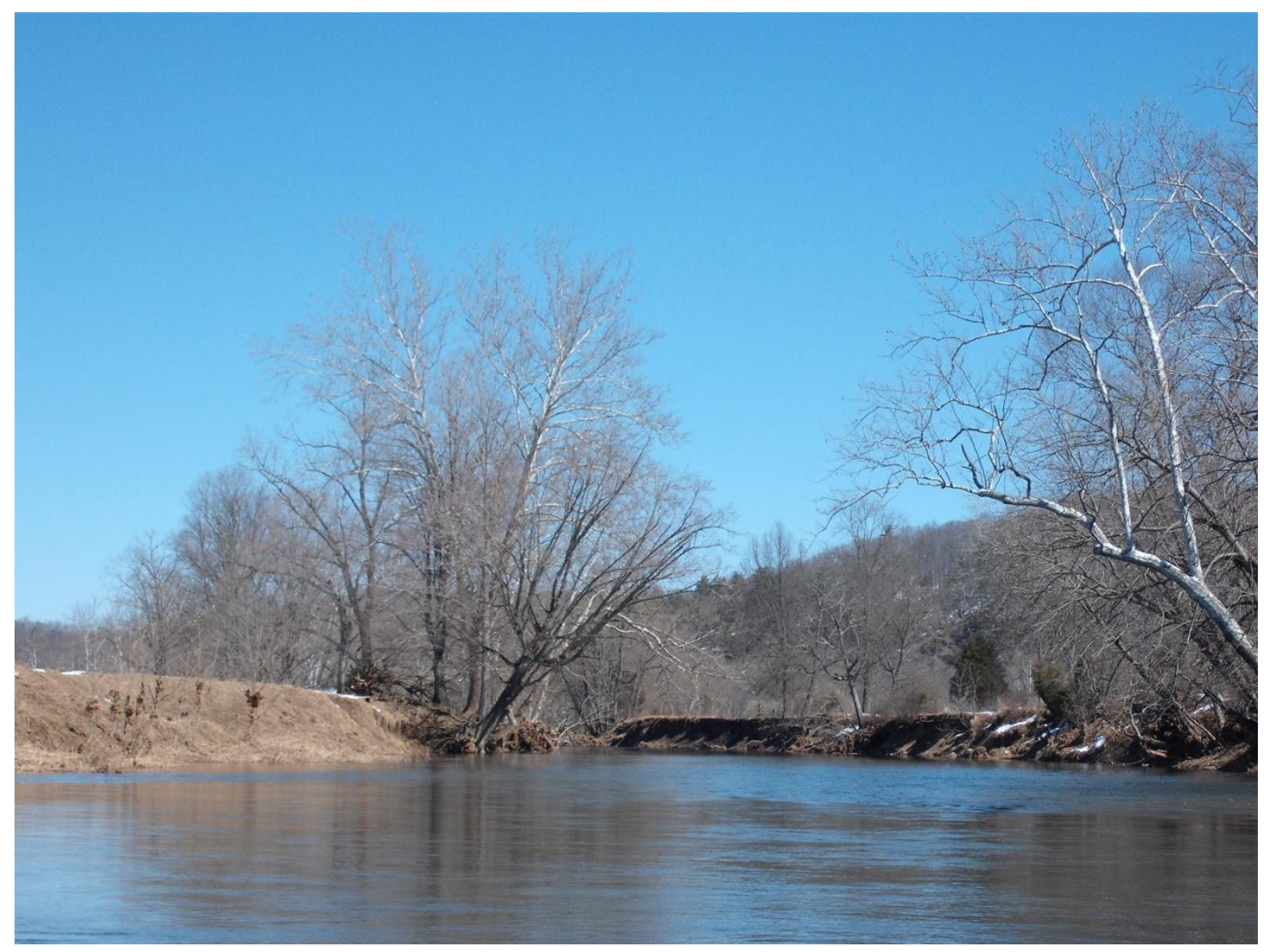

Figure 1: Photograph of the restoration stretch prior to restoration, taken during the Winter 2010 sampling season, March 2010. Mr. Rudolph's property is on the left, Mr. Frye's property on the right. 


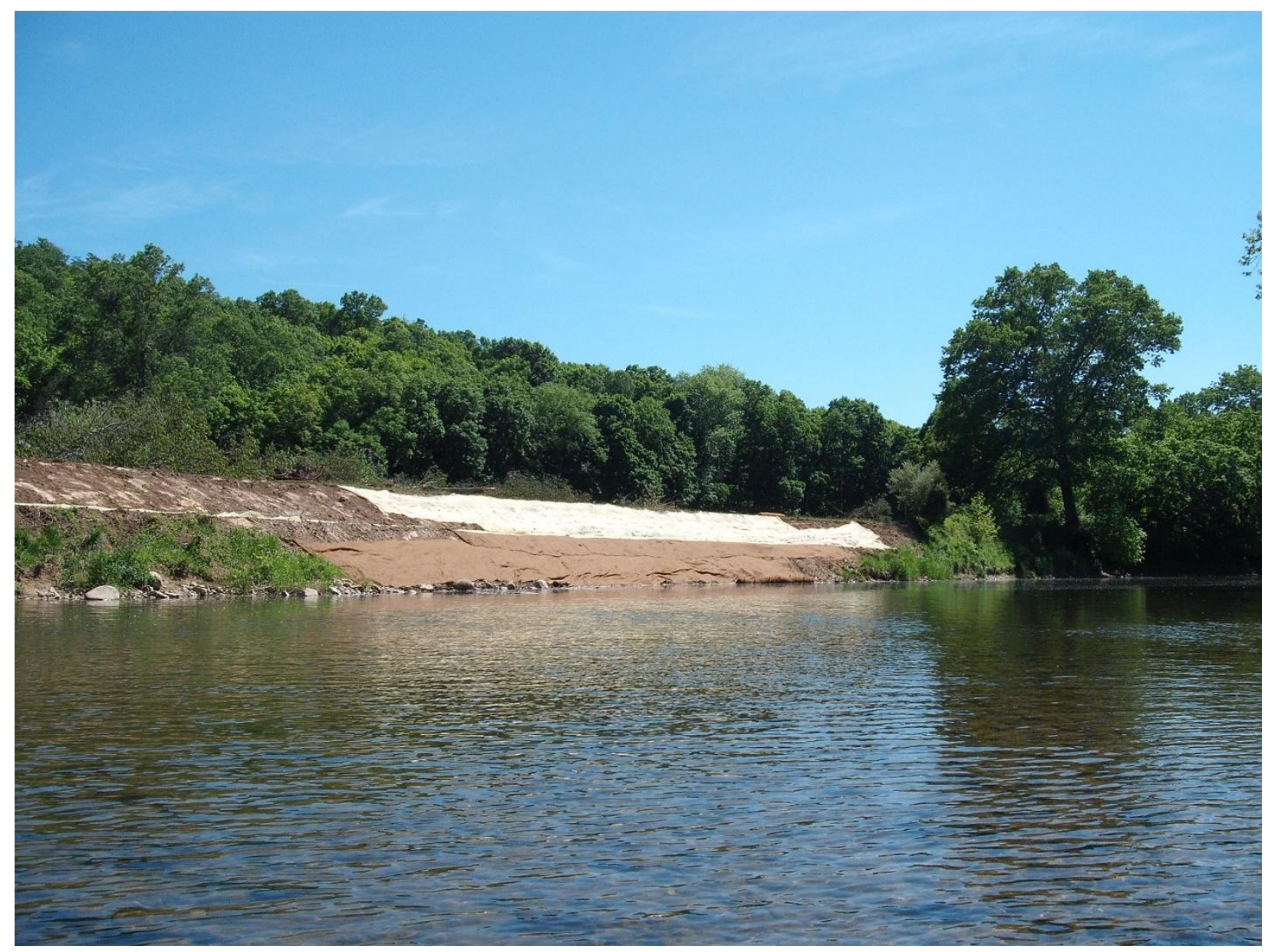

Figure 2: Photograph of the restoration stretch (Mr. Frye's property) taken during restoration (Spring 2010 sampling season), May 2010. 


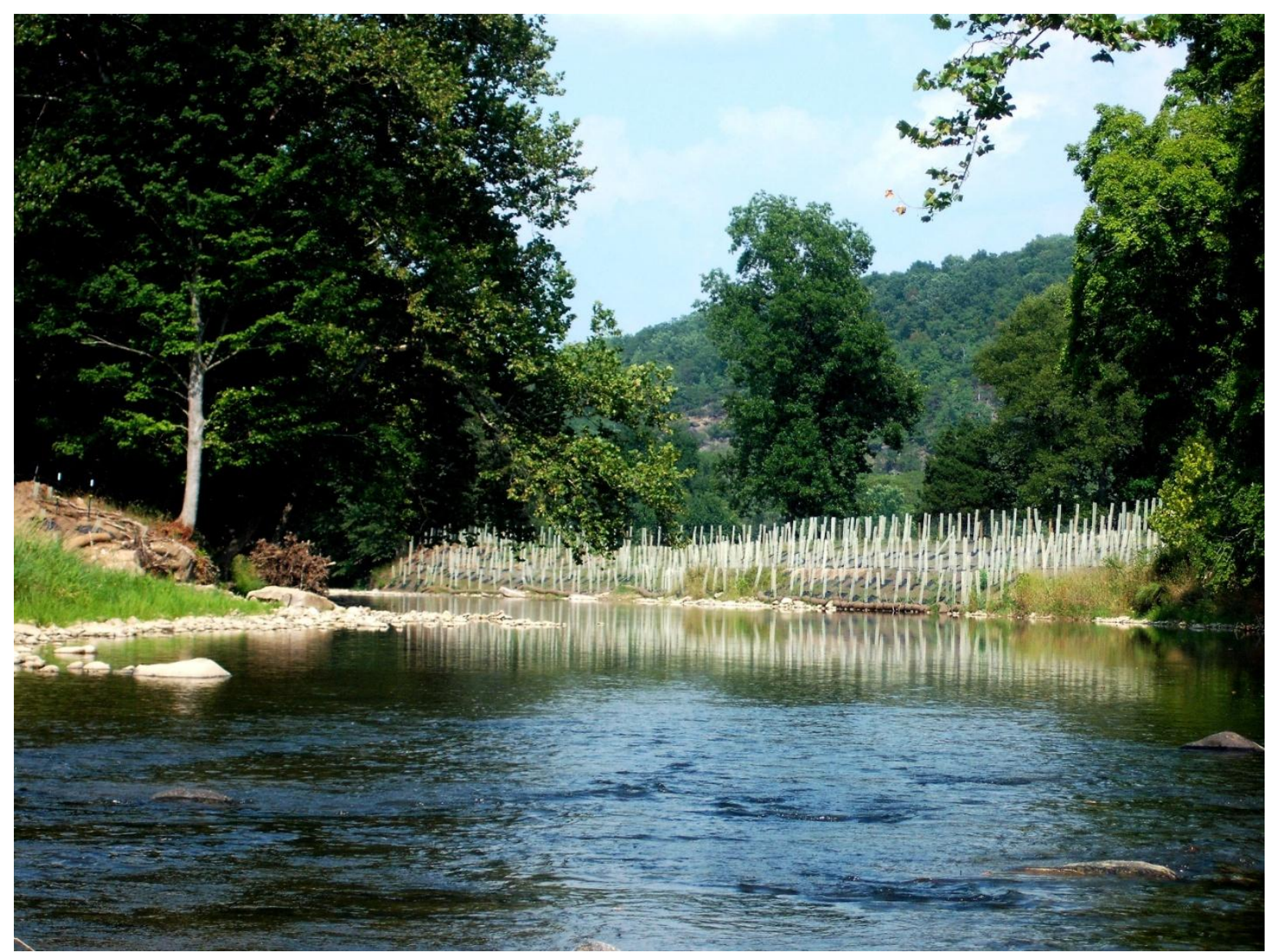

Figure 3: Photograph of the restoration stretch taken during the Summer 2010 sampling season, July 2010. Mr. Rudolph's property is on the left, Mr. Frye's property on the right. Note the native tree plantings (with white tree tubes) and log vane on the right, and the electric exclusion fencing visible on the left. 


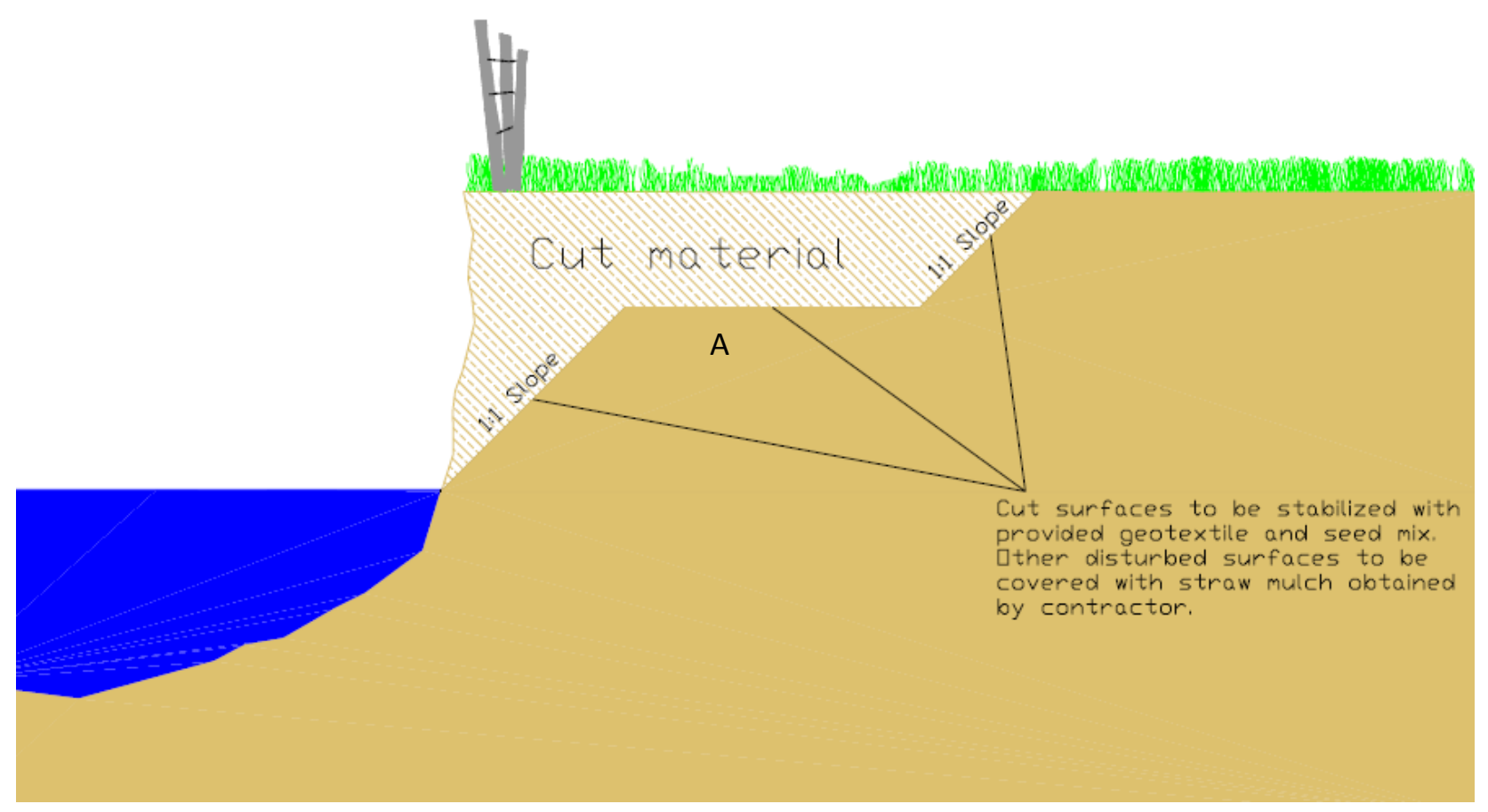

Figure 4: Diagram of the river bank before and after excavation of sediment to construct an artificial floodplain (A). 


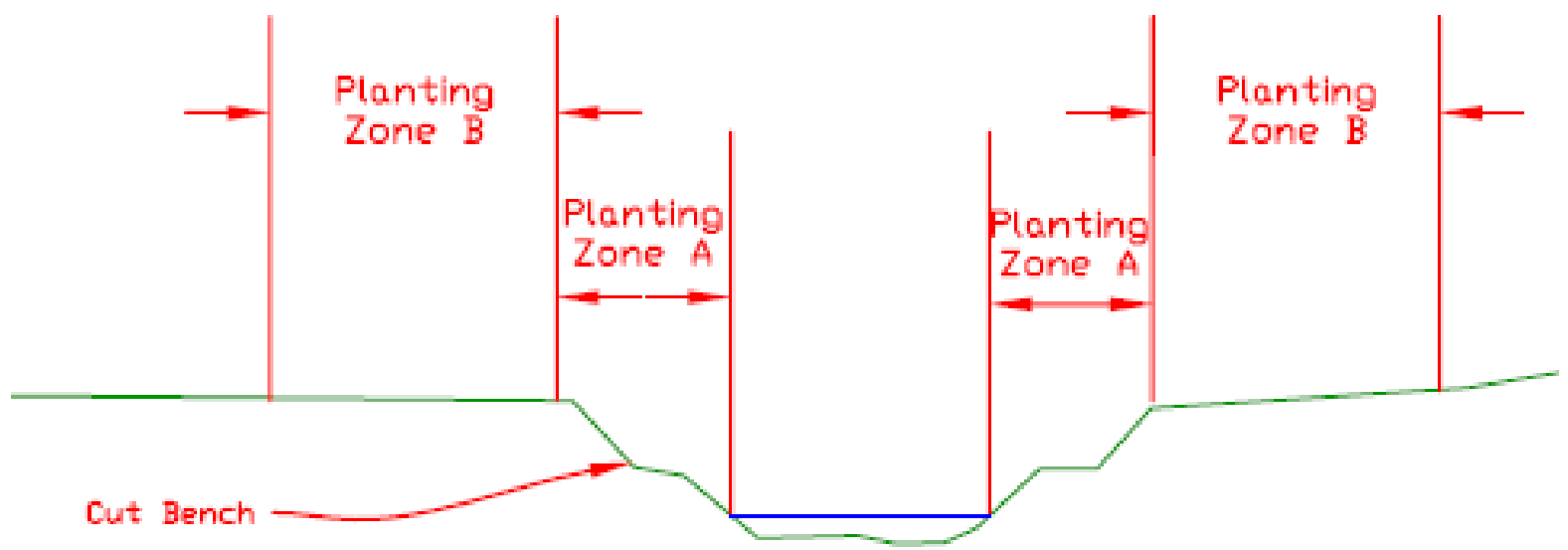

Figure 5: Location of the two planting zones along the restoration stretch. Zone a stretches from the water's edge to the top of the excavated bank, and zone b stretches away from the top of the bank ( $35 \mathrm{~m}$ on the Rudolph bank and $50 \mathrm{~m}$ on the Frye bank). Each zone received a combination planting of woody vegetation species adapted to the zone's level of moisture. 


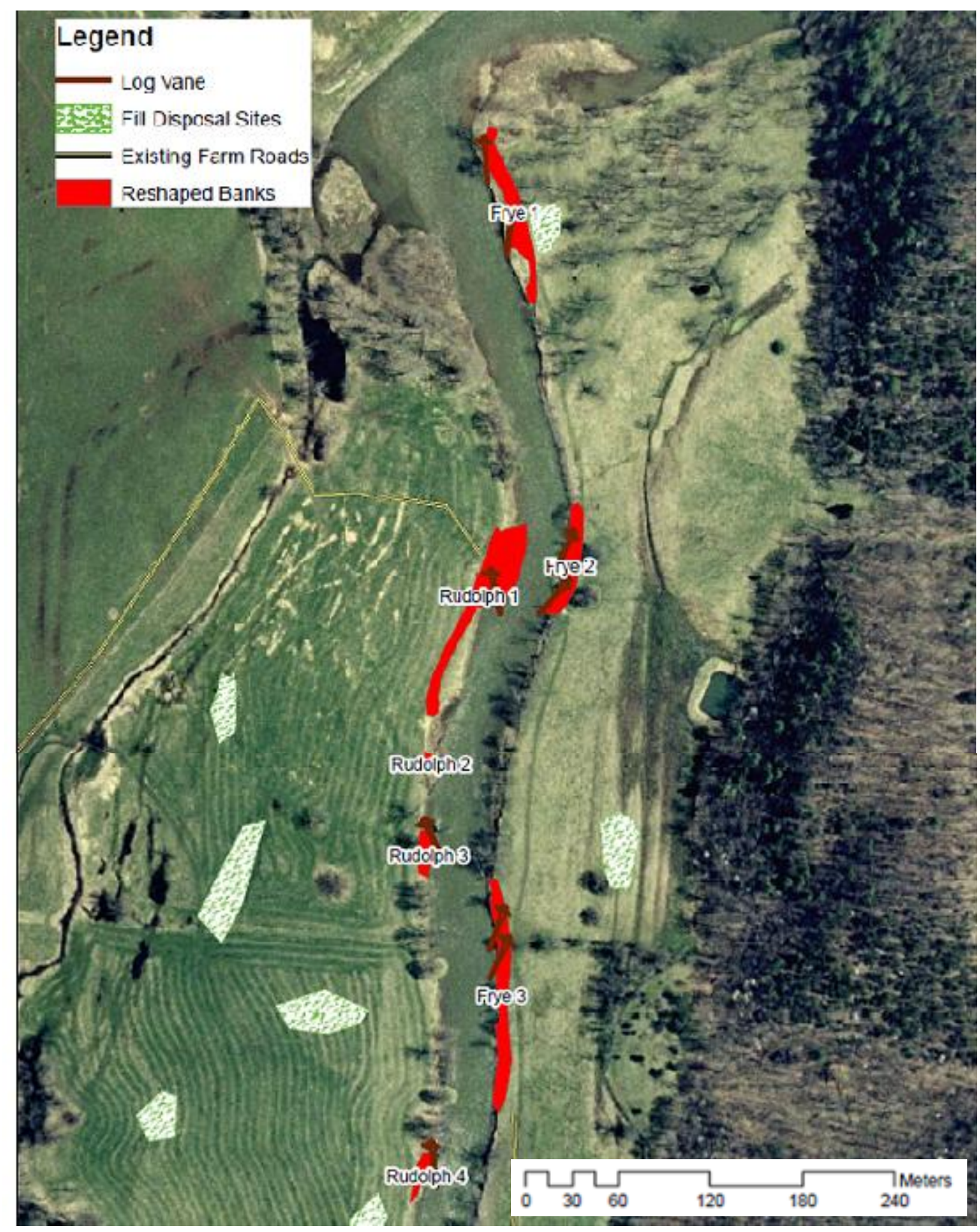

Figure 6: Map of the locations of all nine log vanes (three on the Rudolph bank and six on the Frye bank) placed in the Cacapon River. These vanes were stabilized with gravel, boulders, and metal cables. 


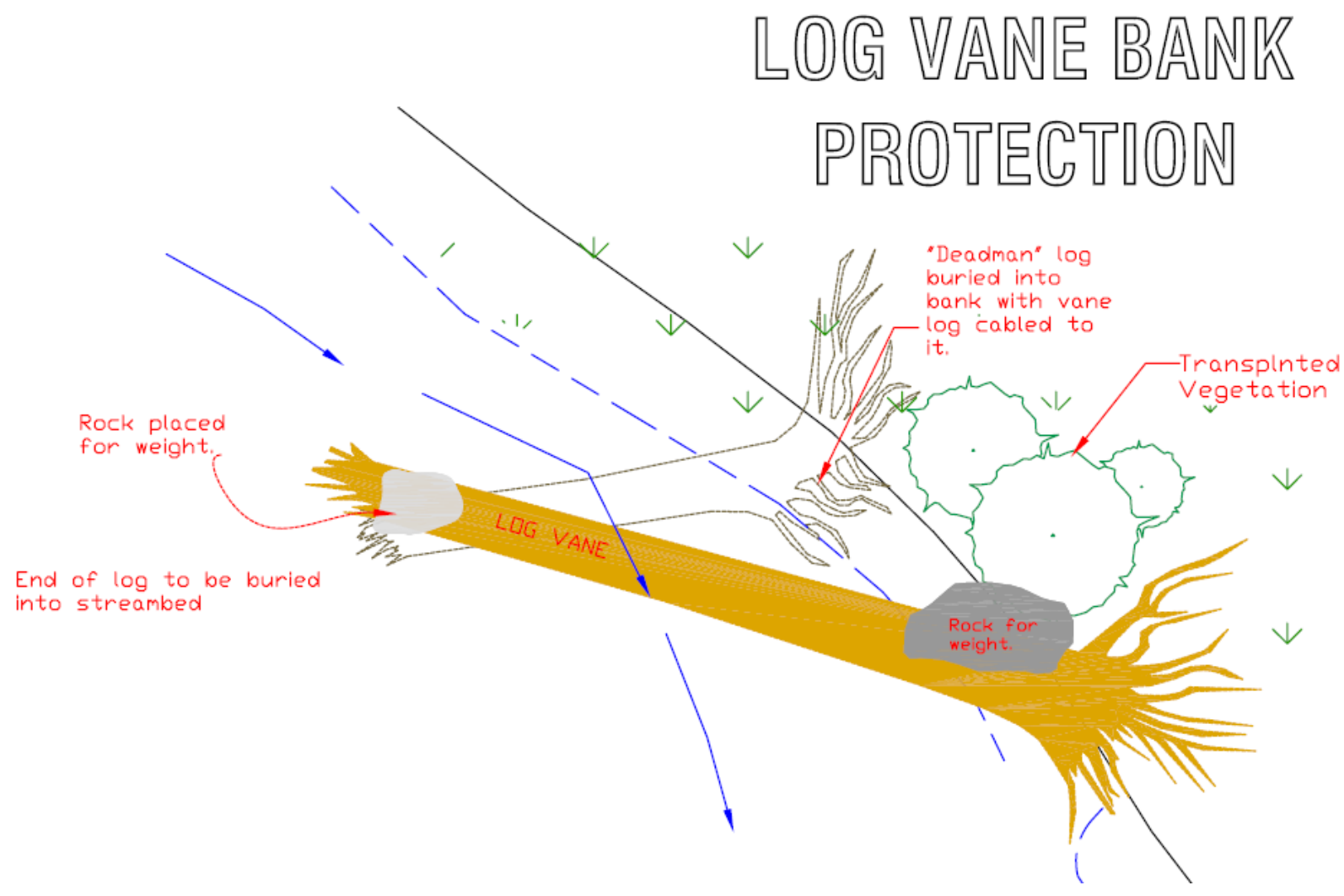

Figure 7: Structure of log vanes placed in the Cacapon River; in all nine were constructed within the restoration stretch to direct water away from weakened sections of the bank. The blue arrows indicate flow direction of the thalweg. 

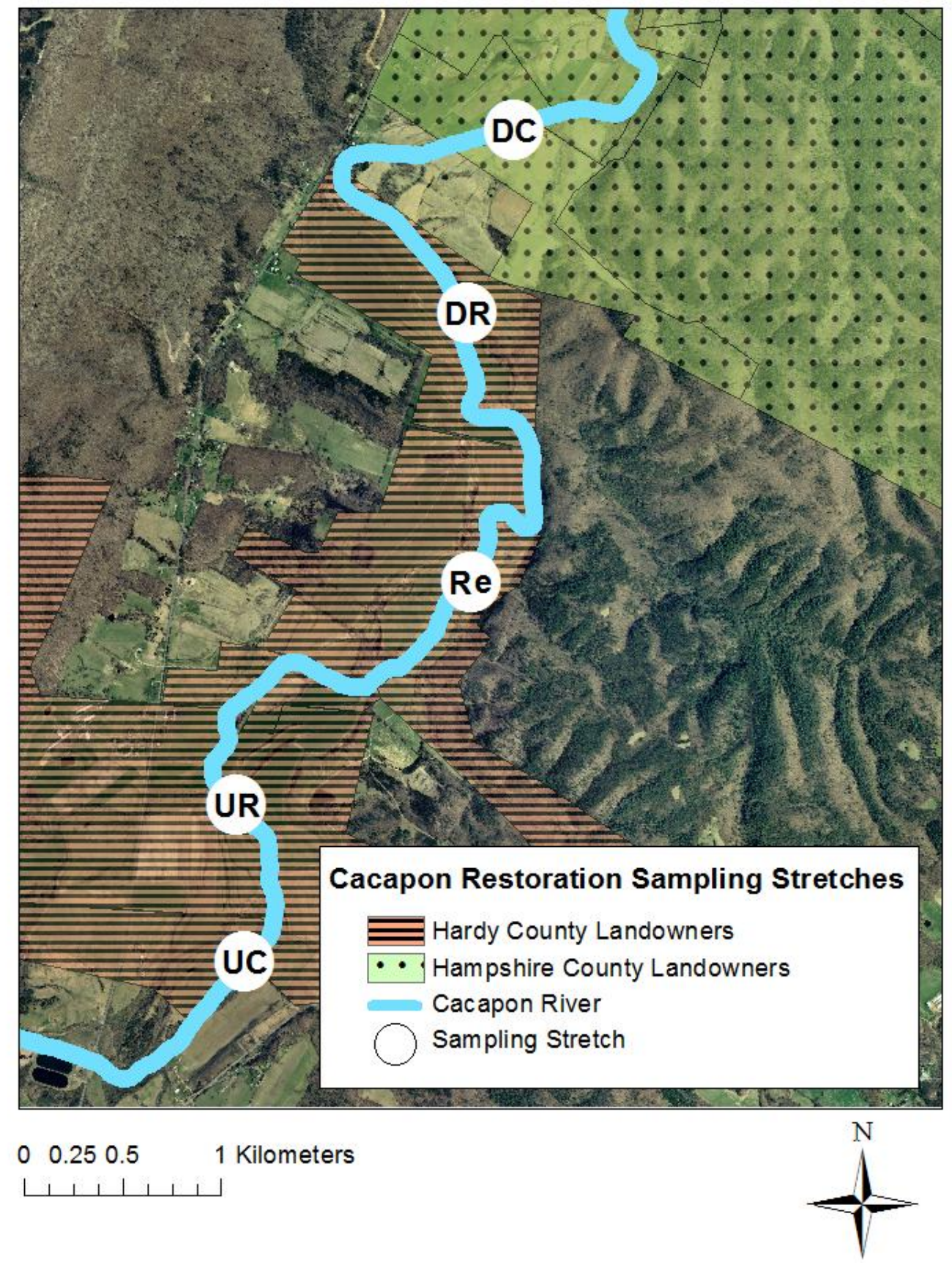

Figure 8: Map of the restoration stretch, two control stretches, and two reference stretches in the Cacapon River. Upstream control (impaired stretch, but not receiving restoration) denoted 'UC', downstream control denoted 'DC'. Upstream reference (unimpaired, natural stretch) denoted 'UR', downstream reference denoted 'DR'. The restoration stretch denoted 'Re'. 


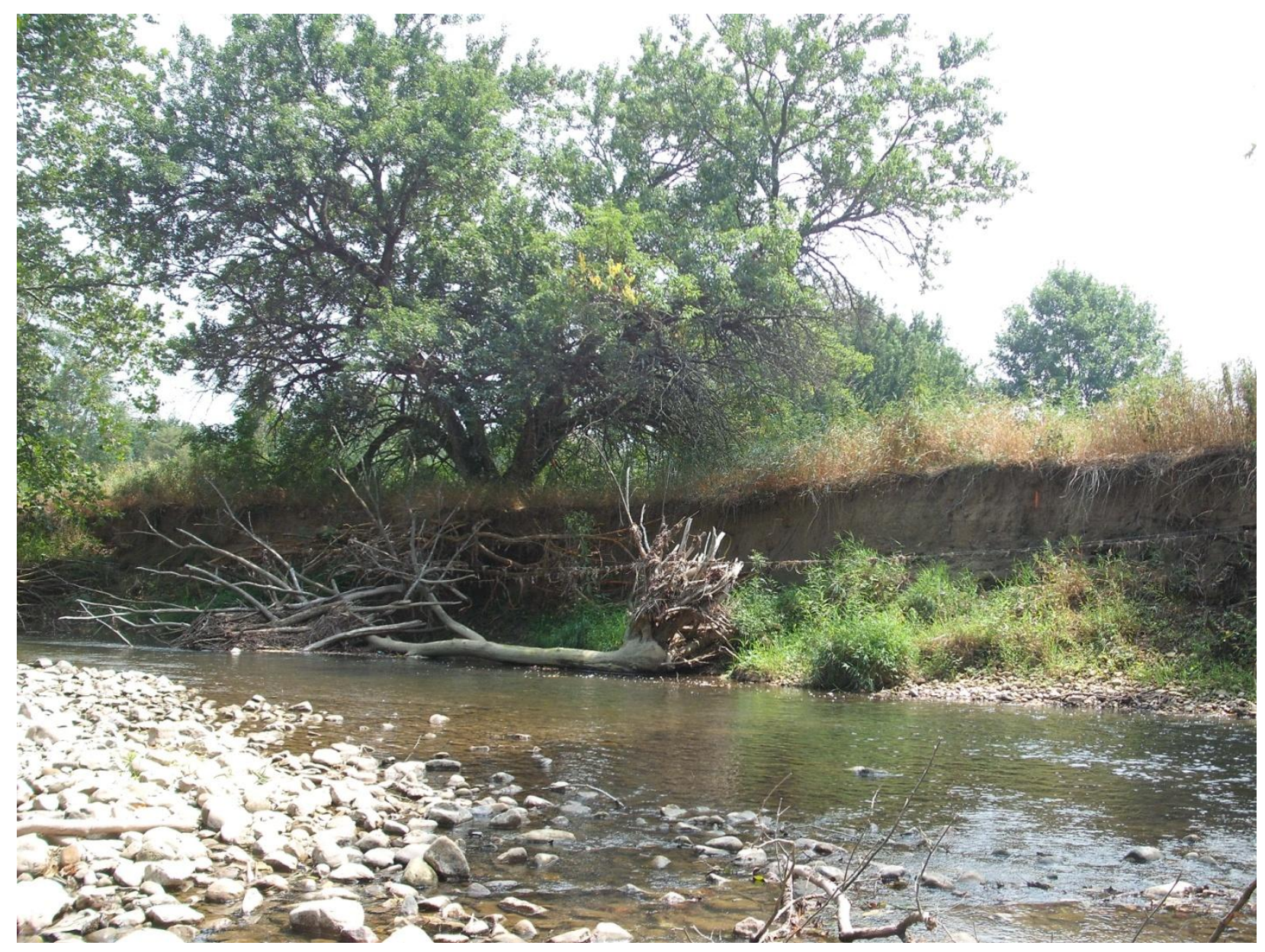

Figure 9: Photograph of the upstream control stretch (impaired stretch not receiving restoration) taken during the Spring 2010 sampling season, May 2010. Note the heavily eroding, sloped bank and low channel fullness (visible point bars). 


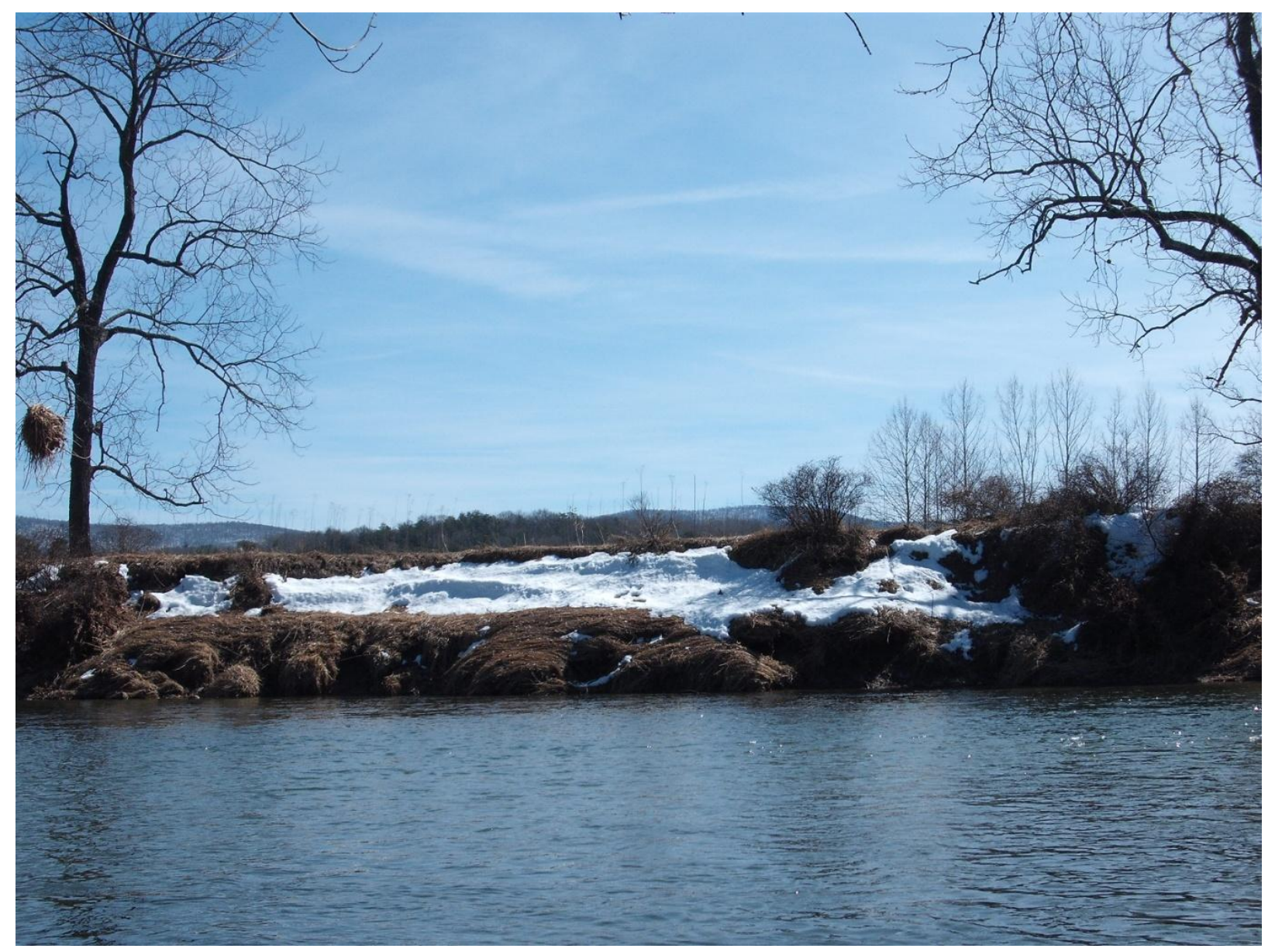

Figure 10: Photograph of the downstream control stretch (impaired stretch not receiving restoration) taken during the Winter 2010 sampling season, March 2010. Note the lack of riparian buffer and eroding banks (visible on the right). 


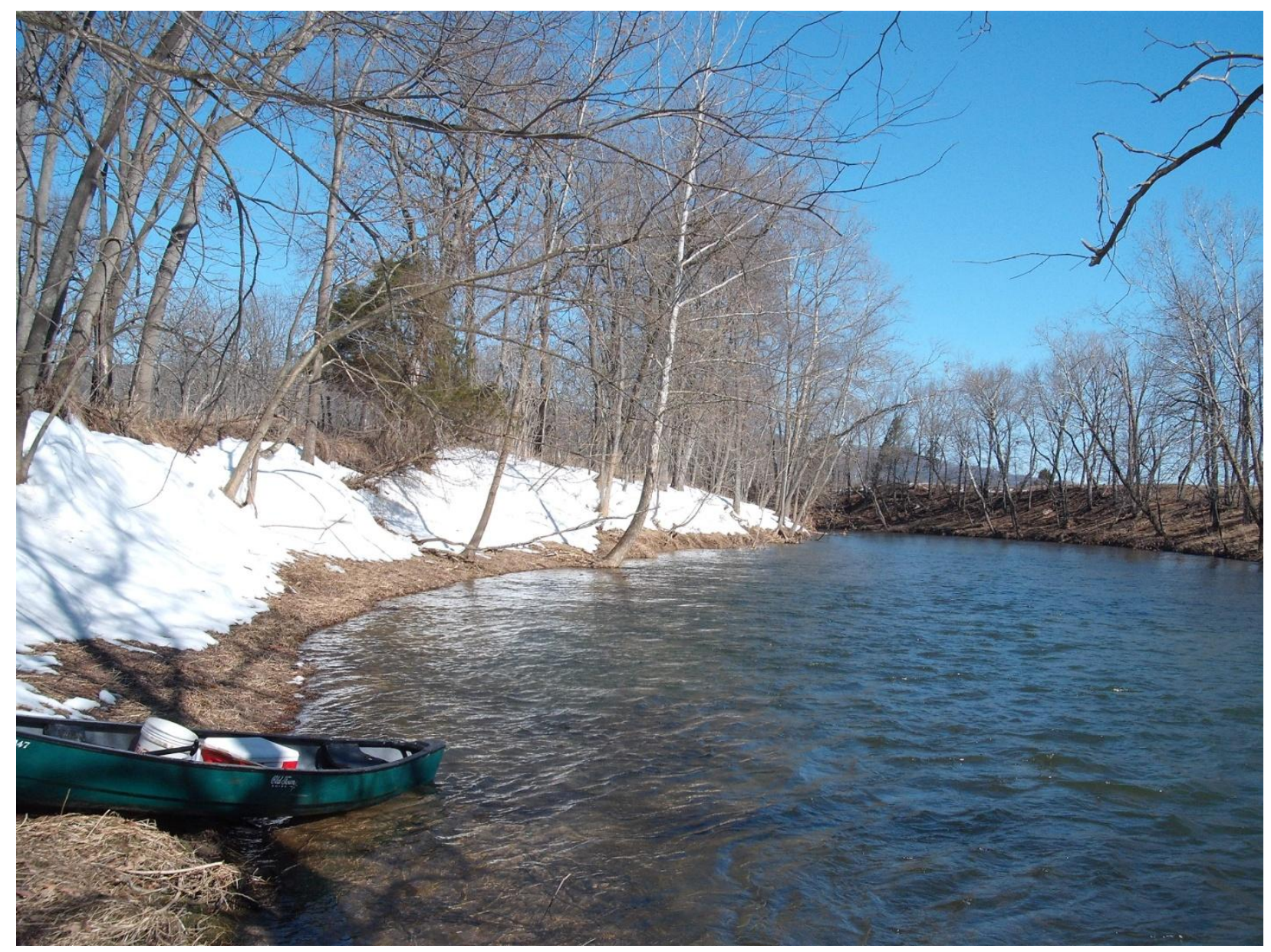

Figure 11: Photograph of the upstream reference stretch (unimpaired, natural stretch) taken during the Winter 2010 sampling season, March 2010. Note the healthy riparian buffer, full channel, and gently sloping banks. 


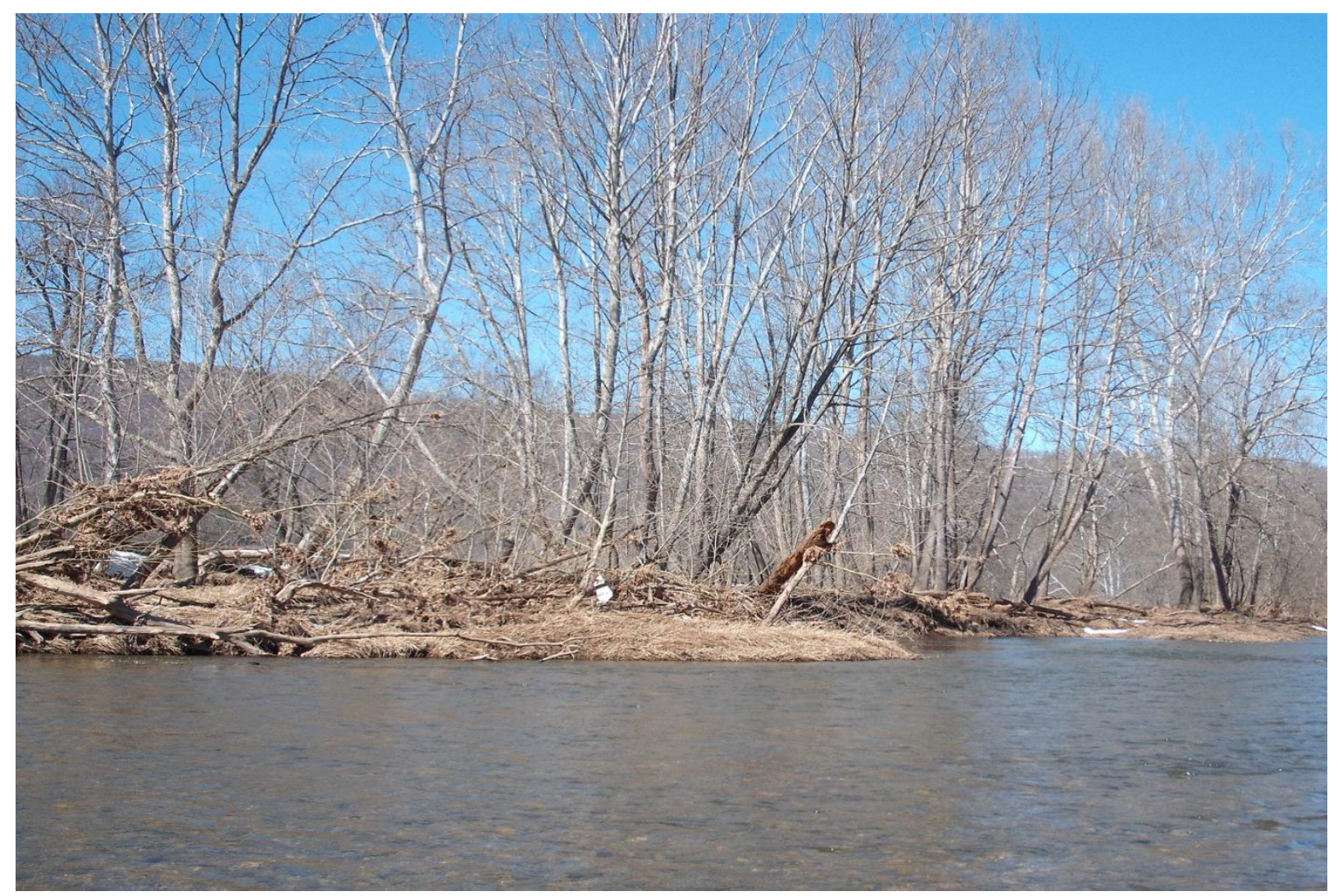

Figure 12: Photograph of the downstream reference stretch (unimpaired, natural stretch) taken during the Winter 2010 sampling season, March 2010. Note the healthy riparian buffer and gently sloping banks. 


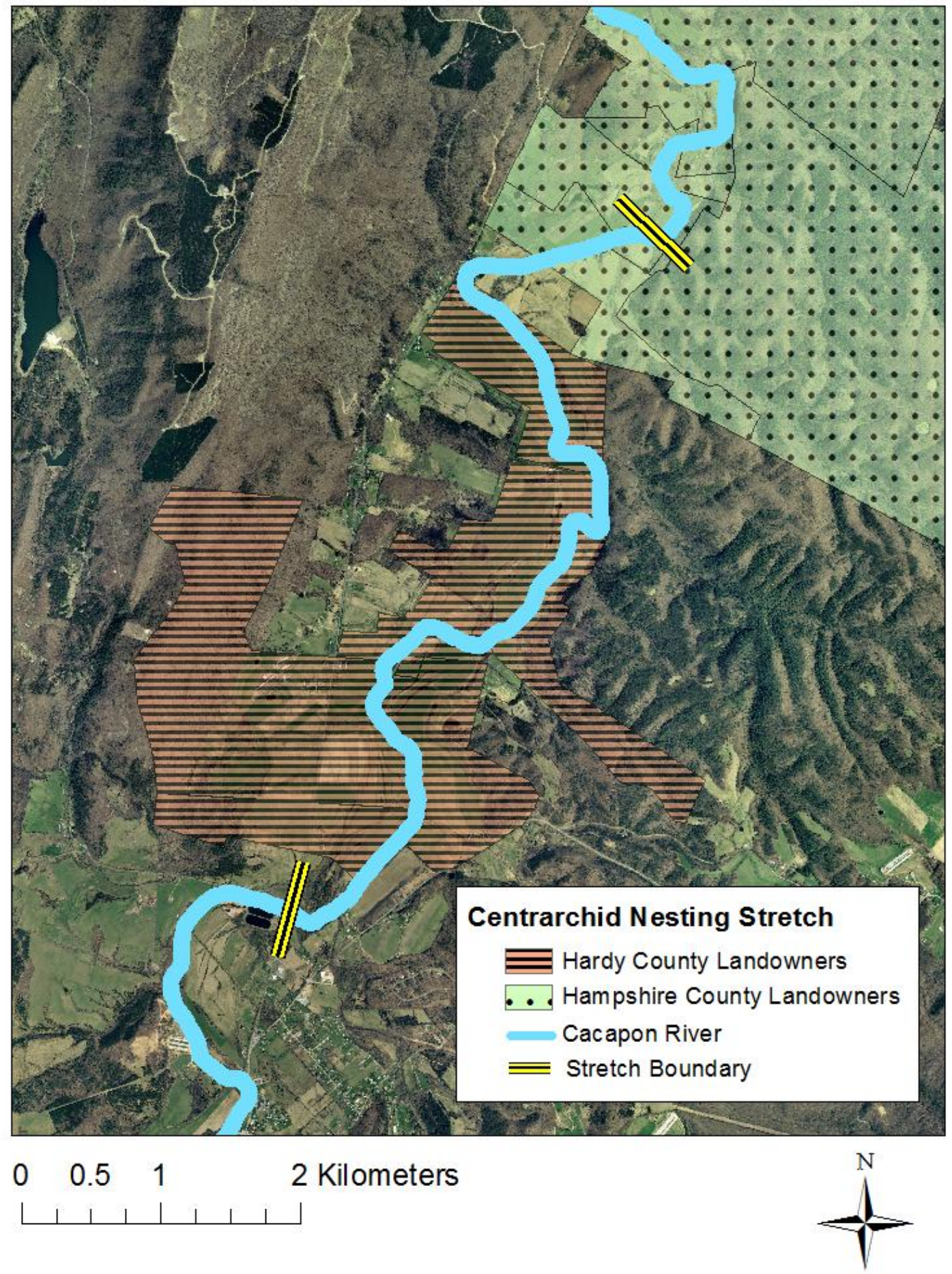

Figure 13: Map of the Cacapon River stretch in Hardy and Hampshire Counties, West Virginia that was surveyed for centrarchid nests, showing the upper and lower stretch boundaries. 


\title{
CHAPTER II
}

COMMUNITY-LEVEL RESPONSE OF FISH AND AQUATIC MACROINVERTEBRATES

TO STREAM RESTORATION IN A THIRD-ORDER TRIBUTARY OF THE POTOMAC

RIVER

\author{
Stephen M. Selego ${ }^{1}$ \\ Charneé L. Rose ${ }^{1}$ \\ Stuart A. Welsh ${ }^{2}$ \\ James T. Anderson ${ }^{1.3}$
}

${ }^{1}$ Division of Forestry and Natural Resources, Wildlife and Fisheries Resources Program,

West Virginia University, PO Box 6125, Percival Hall, Morgantown, WV 26506

${ }^{2}$ WV Cooperative Fish and Wildlife Research Unit, West Virginia University, Morgantown, WV 26506

3 address correspondence to James T. Anderson, Ph.D., Environmental Research Center, West Virginia University, PO Box 6125, Percival Hall, Morgantown, WV 26506. email:

jim.anderson@mail.wvu.edu, phone: (304) 293-3825, fax: (304) 293-2441

Written in the style of:

Restoration Ecology 


\begin{abstract}
Multiple stream-bank and in-stream restoration techniques were applied to a degraded stretch of the Cacapon River in Hardy County, West Virginia during Spring 2010. This stretch, along with two degraded control stretches and two natural reference stretches, were sampled for aquatic macroinvertebrates and fishes before, during, and after restoration efforts (2009 through 2010). Macroinvertebrates were sampled using kick-sampling techniques and a hand screen, and analyzed with a modified stream condition index. Across four sampling seasons, 99 genera in 66 taxa were collected. The most dominant functional feeding group at the restoration stretch before restoration was collector-gatherers; following restoration, the most dominant groups were collector-filterers and scrapers. Of the eight metrics used in the modified index, three (total taxa, total genera, and Hilsenhoff Biotic Index value) successfully differentiated the reference stretches from the control stretches during all sampling seasons. The restoration stretch index scores were approximately equal to those of the control stretches before restoration, and approximately equal to those of the reference stretches after restoration; the restoration stretch score was lower than all others during restoration. Community analysis using PERMANOVA supported the hypothesis that the restoration stretch resembled a control stretch before restoration, and resembled a reference stretch after restoration. Fishes were sampled from the Cacapon River using backpack electrofishing units, and analyzed with two indices of biotic integrity designed for mid-Atlantic drainages. Across all sampling seasons, 33 species in six families were collected. Of the two indices considered, the Daniels et al. (2002) index successfully differentiated the control and references stretches before and after restoration. The McCormick et al. (2001) index scored the upstream control stretch as a reference. The restoration stretch scored between the control and reference stretches (Daniels index) both before and after
\end{abstract}


restoration; the restoration stretch score was lower than all others during restoration. The aquatic communities sampled have responded positively to short-term restoration efforts; however, continued sampling is required to determine true long-term effects.

\section{Introduction}

Lotic systems (streams and rivers) provide important ecological services, including drinking water, food production/irrigation, and waste transport (Arthington et al. 2010). Healthy lotic systems often support diverse aquatic and riparian biological communities. However, as an increasing percentage of the world's lotic systems become impaired due to anthropogenic activity, restoration practices become increasingly important to mitigate this impairment and maintain the services provided.

Often, the goal of stream restoration is to improve system health, based on biological communities (Lepori et al. 2005). However, different restoration techniques have different effects on these communities (Alexander \& Allan 2007). In-stream structures such as root wads and log vanes (the latter of which create scour pools) increase habitat diversity, which is important to maintain high diversity of fishes and macroinvertebrates (Johnson et al. 2002; Radspinner et al. 2010). Riparian buffers, which reduce erosion and pollutant runoff, are essential to stream health (Sweeney et al. 2004; Teels et al. 2006; Miller et al. 2010). Buffers of woody vegetation also reduce water temperature and provide a constant supply of organic matter for macroinvertebrates (Opperman \& Merenlender 2004; Teels et al. 2006; Carline \& Walsh 2007).

Natural stream channel design (NSCD) uses restoration techniques to return the project stretch to a natural condition, defined by criteria present in a second stretch (the "reference reach”) (Rosgen 1998). Successful NSCD improves the physical (bank stability, water 
temperature), chemical (nitrogen and phosphorus inputs), and biological (biodiversity, biomass) conditions of the stretch (Keystone Stream Team 2003) and results in stable conditions (able to carry floods and sediments without significant structural change) (Nagle 2007). However, these conditions are not fully achieved by human actions. Rather, restoration efforts create a stream condition such that over time the stretch will return to and remain at a natural state without assistance (Keystone Stream Team 2003).

To further our understanding of restoration practices, and improve the success of future projects, it is important to measure the effects of past projects on biological communities (Miller et al. 2010; Selvakumar et al. 2010). Unfortunately, post-project evaluation is quite rare (Kondolf \& Micheli 1995; Alexander \& Allan 2007). Long-term effects may also take years to manifest (Moerke et al. 2004; Spanhoff \& Arle 2007). We tracked these effects in a stretch of the Cacapon River, West Virginia, after in-stream and stream-bank restoration techniques following NSCD. Our objectives were to compare the fish and macroinvertebrate communities in the restoration stretch before, during, and after application of techniques to those collected from impaired control stretches and natural reference stretches of the river.

\section{Methods}

\section{Study Site}

The Cacapon River is located in the Eastern panhandle of West Virginia, USA. This area is part of the Ridge-and-Valley physiographic province (Ryder et al. 2009). The climate is humid

continental, with hot summers and year-round precipitation totaling about $91 \mathrm{~cm}$ annually (Gilles 2009). The Cacapon River is a $3^{\text {rd }}$ order tributary of the Potomac River, best approximated as a Rosgen class C channel (Rosgen 1994). 
Stream restoration was conducted on one 500-m stretch of the Cacapon River. This stretch was selected based on a rating system modified from Strager et al. (2011) (Appendix 1a). Most of this property was used as pastureland for cattle; a small percentage was forested. Prior to restoration, average bank height within the stretch was $2.39 \mathrm{~m}$ (right bank) and $2.71 \mathrm{~m}$ (left bank), thalweg depth was $1.03 \mathrm{~m}$, and stream width was $34.37 \mathrm{~m}$. Both banks were nearly vertical, and were being removed by the river at a rate of up to one meter per year (J. L. Pitchford, unpublished data). A number of large trees were in danger of being undercut and entering the river as large woody debris.

Fish and aquatic macroinvertebrate communities were sampled from the restoration stretch before, during, and after restoration. In addition to the restoration stretch, four additional stretches were selected for sampling. Two of these were impaired control stretches in need of restoration but not receiving it. One of these was upstream of the restoration stretch, and one downstream, each no more than $4 \mathrm{~km}$ from the restoration stretch. The remaining two were natural reference stretches, with stable banks and in-stream habitat heterogeneity. One of these was upstream from the restoration stretch and one was downstream, each no more than $4 \mathrm{~km}$ from the restoration stretch (Fig. 1). Each of these stretches was $120 \mathrm{~m}$ long (corresponding to the shortest wadeable distance of any of the stretches to standardize the length sampled) and was selected based on rapid visual habitat assessment (RVHA) scores for riffle-based rivers (Barbour et al. 1999) (Table 1). Stretches with high RVHA scores were selected for reference stretches, and those with low scores were selected for control stretches.

\section{Restoration Methods}

In-stream and stream-bank restoration techniques, organized by Canaan Valley Institute (Davis, West Virginia), were applied to the restoration stretch of the Cacapon River. Both banks, which were previously vertical and quickly eroding, were re-contoured by Red Creek Enterprises 
(excavation company, Dry Fork, West Virginia). By leaving a small section of each bank horizontal, artificial floodplains were created. Native warm-season grasses, pollinator strips, and saplings of native trees and shrubs were planted along bare sections of the banks to begin establishment of riparian buffers. Woody plantings were predominantly pin oak (Quercus palustris), swamp white oak (Q. bicolor), black willow (Salix nigra), and buttonbush (Cephalanthus occidentalis). Most of these were planted in the excavated sections of the bank, which were entirely de-vegetated by the restoration process. These de-vegetated areas were further protected with burlap mesh and coconut-fiber biologs while the plantings grew. The areas containing the plantings were lined with electric fence, installed by Bland Fencing LLC (Petersburg, West Virginia), to prevent access by cattle and deer. During the fall of 2010, invasive species (specifically barberry, Berberis thunbergii; autumn olive, Elaeagnus umbellate; and multiflora rose, Rosa multiflora) were removed from the riparian zone along the right bank of the restoration stretch using a "hack 'n' squirt" method with Roundup® herbicide (Monsanto Co., St. Louis, Missouri, United States). Roundup® is a broad-spectrum herbicide, which uses the active ingredient Glyphosate.

Gravel was excavated from areas of the restoration stretch using heavy machinery, and used to stabilize log vanes planted at nine locations within the stretch. Additional gravel was deposited downstream of the log vanes to create riffle/run habitats beyond the scour pools created by the vanes. The log vanes were angled so as to minimize erosive pressure on the associated banks. Electrical fencing was placed around the restoration banks to eliminate cattle access.

\section{Sampling Methods}

Macroinvertebrates were collected from the Cacapon River during July 2009 and March 2010 (both pre-restoration), during May 2010 (coinciding with active restoration), and during 
July 2010 (following restoration). Each sampling day, six kick-samples were taken from separate riffles within each of the five study stretches. These riffles were selected so as to represent the varying depths and water velocities present within the stretch. Each "kick" indicated a complete disturbance of a square meter area upstream of a $1 \times 1-\mathrm{m}$ hand screen with $500-\mu \mathrm{m}$ mesh for up to one minute. Afterwards, large objects such as rocks and woody debris within the square meter sample area were scraped by hand to dislodge any additional macroinvertebrates. All material trapped in the net after each sample was transferred to $95 \%$ ethanol (Barbour et al. 1999). In the lab, all macroinvertebrates in each sample were separated from the debris by hand. Each specimen was then inspected using a dissecting microscope and identified to the genus level, or lowest taxonomic level possible (Lenat 1988; Peckarsky et al. 1990; Barbour et al. 1999).

Fishes were collected from each study stretch of the Cacapon River during August 2009 (pre-restoration) and August 2010 (post-restoration) (ACUC protocol number: 090407). An additional sample was collected from the restoration site and both control sites during active restoration in May 2010. Fishes were sampled using a backpack electrofishing unit with DC current, a trailing cathode, and a frequency of about $35 \mathrm{~Hz}$ (Smith-Root, Inc., Vancouver, Washington). Shallow riffles were used as the upstream limits of the stretches to prevent continued upstream movement of the fish.

Two researchers, each with an electrofishing unit, made one simultaneous pass (beginning downstream) through the restoration stretch, each control, and each reference (Barbour et al. 1999; Adams et al. 2002). Electrofishing time for each stretch was standardized to 45 minutes. During the electrofishing, each backpack operator was accompanied by an assistant carrying a dipnet and a holding bucket. All fish stunned by the electrofishing units were captured using the dipnets and transferred to one of the two holding buckets. Four large holding bins with 
holes to allow water flow were evenly spaced along the sampling stretch. When the team reached one of these holding bins, the contents of the buckets were quickly transferred to the bin. Plastic mesh was placed over the top of each bin to prevent fish from escaping. In this way, stunned fish were allowed to recover in cool, oxygenated water to minimize mortality.

Once the team reached the upstream limit of the sampling stretch, all fishes in the holding buckets and bins were observed. All easily identified species were examined for anomalies (excessive parasites, torn fins, injuries, and deformities), placed in an age class (adult or juvenile) and immediately released (Barbour et al. 1999; Daniels et al. 2002). Unidentified individuals were anesthetized and euthanized in pharmaceutical-grade MS-222, then these and deceased specimens were fixed in $10 \%$ formalin solution. Collected specimens were later identified to species in the lab.

Once each year in July, a rapid visual habitat assessment (RVHA) was conducted on each of the five macroinvertebrate and fish sampling stretches (Barbour et al. 1999). Each habitat parameter was ranked (1 to 20, 20 indicating optimal conditions) based on a series of visual cues. Specifically, the following parameters were considered: epifaunal substrate and available cover, substrate embeddedness, number of velocity and depth combination, sediment deposition, channel flow status, channel alteration, frequency of riffles, bank stability, bank vegetative protection, and riparian vegetation zone width (Table 1). These parameters correspond to a highgradient stream. Although the Cacapon River is about equally composed of riffles and pools, these RVHAs were conducted only at stretches sampled for macroinvertebrates and fishes, which in turn were only collected from shallow water $(<1.5-\mathrm{m}$ depth $)$.

\section{Data Analysis}

The health of each river stretch was determined using a modified macroinvertebrate index of biotic integrity (IBI), with the following metrics: total genera richness; total taxa (family) 
richness; total Ephemeroptera, Plecoptera, and Trichoptera (EPT) richness; percent of sample composed of EPT; percent of sample composed of Chironomidae; percent of sample composed of two most dominant taxa; Hilsenhoff Biotic Index (Hilsenhoff 1988); and total abundance (Angradi 1999; Barbour et al. 1996; Tetra Tech 2000; Mandaville 2002) (Table 2). The Hilsenhoff Biotic Index (HBI) is calculated by multiplying each taxon's tolerance value by its proportion in the sample, then summing these products. Tolerance values are low for intolerant taxa and high for tolerant taxa, therefore low HBI scores indicate better conditions than high HBI scores.

Within each sampling season, the five sampling stretches were ranked (1 through 5, 5 indicating the healthiest site) for each of the eight metrics. Sites with tied values within a metric each received the average of the integer ranks that would be assigned to those sites (e.g., if the sites that would receive ranks 2 and 3 were tied, they each received a rank of 2.5). The sum of these metric ranks were calculated for each site and each sampling season; these values are denoted as "IBI rank sums". Note that the rank sum scores between stretches within a sampling season are not independent (they are constrained to a total value of 120 across all stretches within the season). As the score for one stretch increases, the scores of at least one other stretch will necessarily decrease. Therefore, these scores represent comparative community health, and are not interpretable when considered separately. Macroinvertebrates were also placed into five functional feeding groups (collector-gatherer, collector-filterer, predator, scraper, and shredder), and the proportion of each sample composed of each of these groups was calculated (Mandaville 2002).

A fish community IBI was calculated following a modified index developed for MidAtlantic drainages in New York, Pennsylvania, New Jersey, and Maryland (Daniels 2002). The 
following metrics were considered: total species, total benthic insectivorous species, total water column species, total terete minnow species, percent dominant species, percent Catostomus commersoni (white sucker), percent per trophic guild (generalist, insectivore, top predator), individuals per sample, percent juveniles, and percent with anomalies. Metrics were each scored 1,3 , or 5 (5 indicating ideal conditions) (Table 3 ).

A second IBI, developed for the Mid-Atlantic Highlands region, was also calculated. This IBI, developed by McCormick et al. (2001), included the following metrics: total non-tolerant cyprinid species, total benthic species, total sensitive species, proportion in Cottidae, proportion of tolerant individuals, proportion of non-native individuals, proportion of piscivores, proportion of macro-omnivores, and proportion of gravel-spawners. Each metric was scored based on a 0-10 scale, and scores were assigned to Cacapon sites based on Trebitz et al. (2003) (Table 3).

To visualize the classification strength of the stretches (control vs. reference vs. pre- and post-restoration), we conducted nonmetric multidimensional scaling (NMDS) in the statistical program $\mathrm{R}$ (version 2.11.1). The procedure was run once using the macroinvertebrate community data from the summers before (2009) and after (2010) restoration efforts, and again using the summer 2009 and summer 2010 fish community data. By default, program R uses a Wisconsin double-standardization and the Bray-Curtis distance matrix. Multidimensional scaling is robust to frequent zero-values and lacks assumptions regarding multivariate normality (Johnson et al. 2010). The procedure was run separately with two, three, and four dimensions and multiple random starts. Two dimensions were used for all analyses, as additional dimensions did not reduce the stress levels appreciably. We also correlated (using Pearson's correlation coefficient and 1000 permutations) each metric to the corresponding NMDS ordination. 
The differences in macroinvertebrate and fish community composition between control, reference, and restoration (pre- and post-) stretches were analyzed using permutational multivariate analyses of variance (PERMANOVA) using distance matrices in the statistical program R (function adonis) (Wildsmith et al. 2009). Since PERMANOVA does not require multivariate normality, the data were not transformed (Johnson et al. 2010). Only community data from the summers of 2009 and 2010 were considered for each community. Four additional PERMANOVAs were run, denoting the pre- and post-restoration stretches as either control or reference stretches (therefore having only two stretch types, as opposed to three above). All combinations were considered (control and reference, reference and control, control and control, reference and reference), and their permutational p-values were compared at $\alpha=0.05$.

\section{Results}

\section{Rapid Visual Habitat Assessments (RVHA)}

The RVHA scores from the upstream control stretch decreased from 139 to 136 between Summer 2009 and Summer 2010; the upstream reference increased from 152 to 155 between the two years. The restoration stretch showed the greatest increase in RVHA score, increasing from 136 to 141 following restoration efforts. Both downstream stretches decreased from 2009 to 2010; the downstream control changed from 136 to 130, and the downstream reference changed from 163 to 157 (Appendix Ib).

\section{Macroinvertebrate Community Assessment}

A total of 30,487 individual aquatic macroinvertebrates representing 66 families and 99 genera were collected from the five study stretches across four sampling seasons (Appendix IIb). Thirty of the 66 families were EPT orders, totaling 51.5\% of individuals (Fig. 2). Stenelmis (Elmidae), at $14.5 \%$, was the most commonly collected macroinvertebrate. Non-biting midges 
(Chironomidae) composed $10.8 \%$ of individuals. Six other genera were represented by at least 6\% of individuals: Ephemerella (Ephemerellidae), Stenonema (Heptageniidae), Hydropsyche (Hydropsychidae), Isonychia (Isonychiidae), Psephenus (Psephenidae), and Prosimulium (Simuliidae).

Of the eight macroinvertebrate IBI metrics, three (total genera, total taxa, and Hilsenhoff index) scored higher in reference stretches than control stretches during all four sampling seasons. Two additional metrics (percent EPT and percent Chironomidae) successfully differentiated the control from reference stretches for three of the four seasons. Using this differentiation as a measure of metric strength, "percent dominant two taxa" (which only differentiated in the during-restoration sample) was the weakest.

During all four sampling seasons, the two reference stretches had higher IBI rank sum scores (RSS) than the two control sites (Fig. 3). During the summer pre-restoration season, the restoration stretch had a RSS of 21 ( 0.5 higher than the highest control stretch score and 8 lower than the lowest reference stretch score). During the winter pre-restoration season, the restoration stretch RSS was 19.5, and medial to the two control stretch scores. During restoration, the restoration stretch RSS was 8, indicating it ranked worst on all 8 individual metrics for the season (Appendices IIIb-Xb). Following restoration, the restoration stretch RSS was 26 (8.5 higher than the highest control stretch and 2 lower than the lowest reference stretch) (Fig. 3).

Across all study stretches and sampling seasons, scrapers were the most abundant FFG with 10,196 individuals (33.44\% of individuals). Shredders, at 598 individuals (1.96\%), were the least represented FFG. The majority of shredders were collected during the winter 2010 prerestoration sampling. Before restoration efforts (during both summer and winter sampling seasons) and during restoration, collector-gatherer was the most dominant feeding group at the 
restoration stretch. Following restoration efforts, collector-filterers and scrapers became the most dominant groups at the restoration stretch (Appendices XIb).

An NMDS plot based on a dimensionality of two was used for analysis, resulting in a stress of 10.76, which was deemed acceptable (Clarke 1993) (Fig. 4). Stretch type and year both separated in ordination space. The restoration stretch clustered with the control stretches prerestoration and the reference stretches post-restoration. In general, the 2009 samples clustered on the left half of the ordination space (negative NMDS1 values), and the 2010 samples clustered on the right half (positive NMDS1 values). Control and reference stretches separated vertically, with control stretches generally having positive NMDS2 values and reference stretches having negative NMDS2 values. The pre-restoration sample clustered among the 2009 control stretches, and the post-restoration sample clustered with the 2010 reference stretches. Four metrics (Hilsenhoff Index value, abundance, percent dominant taxa, and percent Chironomidae) were significantly correlated with the NMDS solution (Table 4). Percent EPT taxa was the least correlated.

Using PERMANOVA, stretch types (with pre- and post-restoration samples both labeled as 'restoration') were significantly different based on community composition $\left(F_{[2,4]}=3.54, p=\right.$ 0.011). Control and reference stretches were significantly different from one another $\left(F_{[1,5]}=\right.$ $5.91, p=0.028$ ), but neither of those types were different from the restoration stretches (control vs. restoration $F_{[1,4]}=1.58, p=0.207$; reference vs. restoration $\left.F_{[1,4]}=0.79, p=0.651\right)$. Although in the NMDS ordination sampling year appeared to be significant, PERMANOVA did not detect this difference $\left(F_{[1,4]}=1.89, p=0.161\right)$. The interaction effect between stretch type and year was also not significant $\left(F_{[2,4]}=1.56, p=0.171\right)$. 
The PERMANOVA with pre-restoration labeled as a control stretch and post-restoration labeled as a reference stretch resulted in the greatest significant difference between the stretch types $\left(F_{[1,6]}=8.20, p=0.001\right)$. The PERMANOVA labeling both restoration samples as references also produced a significant difference $\left(F_{[1,6]}=4.85, p=0.019\right)$. The two other combinations were not significant: pre and post as controls $\left(F_{[1,6]}=2.98, p=0.051\right)$, and pre as a reference and post as a control $\left(F_{[1,6]}=1.77, p=0.175\right)$.

\section{Fish Community Assessment}

Overall, 33 fish species and 2,305 individuals were collected from the Cacapon River (Appendix XIIb and XIIIb). Across all stretches and sampling seasons, bluntnose minnows (Pimephales notatus) were the most common fish species collected (40.5\% of individuals). Redbreast sunfish (Lepomis auritus, 10.5\%), rosyface shiners (Notropis rubellus, 8.1\%), and tessellated darters (Etheostoma olmstedi, 7.6\%) were also common. Northern hogsuckers (Hypentelium nigricans, 1.8\%) were the most common species that is intolerant of organic pollution (Trebitz et al. 2003). After redbreast sunfish, rock bass (Ambloplites rupestris, 1.9\%) and smallmouth bass (Micropterus dolomieu, 1.0\%) were the most common centrarchid species collected. In all, eight species of centrarchids were collected from the river (Appendix XIVb).

The two reference stretches scored higher than the two control stretches during prerestoration for the Daniels (2002) IBI (Fig. 5). Post-restoration, the two reference stretches again scored higher than the two control stretches. The restoration stretch score was below the score for the two reference stretches both pre- and post-restoration. During restoration, the restoration stretch scored lower than other stretches.

The metrics 'total terete minnows' and 'percent juvenile and adult' successfully differentiated the reference stretches from the control stretches post-restoration (Appendix XVb). No individual metric differentiated the reference stretches from the three impaired stretches pre- 
restoration. The 'percent anomaly' metric scored low for most stretches during the pre- and postrestoration sampling seasons, although less so during restoration.

The McCormick (2001) IBI scored the two reference stretches higher than the downstream control stretch for pre- and post-restoration (Fig. 6). However, the upstream control stretch scored higher than at least one reference stretch for both pre- (73) or post-restoration. The restoration stretch scored lower than the reference stretches and the upstream control stretch for both pre- and post-restoration. During restoration, the restoration stretch scored lower than other stretches.

Only 'percent Cottidae' and 'percent gravel-spawners' successfully differentiated the reference stretches from the three impaired stretches pre-restoration; however, these metrics did not successfully differentiate post-restoration (Appendix XVIb). The metric 'total non-tolerant cyprinid species' was relatively strong at differentiating reference from impaired stretches for both pre- and post-restoration samplings.

An NMDS plot based on a dimensionality of two was used for analysis of fish community data, and resulted in a stress of 11.25 (Fig. 7). In general, 2009 samples had negative NMDS1 and NMDS2 values, whereas 2010 samples had positive values on the two axes. However, the reference stretches did not appear to separate from the control stretches in ordination space. Of the 12 Daniels (2002) metrics, only 'percent anomalies' was significantly correlated $\left(r^{2}=0.71, p<0.001\right)$ with the NMDS solution (Appendix XVIIb), although several other metrics had relatively low $p$-values, including 'percent dominant species' $\left(r^{2}=0.44, p=\right.$ $0.126)$ and 'percent juvenile and adult' $\left(r^{2}=0.42, p=0.134\right)$. Of the McCormick $(2001)$ metrics, only 'percent exotic species' $\left(r^{2}=0.65, p=0.023\right)$ was significantly correlated with the NMDS 
solution (Appendix XVIIb). 'Percent Cottidae' $\left(r^{2}=0.52, p=0.084\right)$ and 'percent piscivores' $\left(r^{2}\right.$ $=0.48, p=0.109)$ were also correlated, although not significantly at $\alpha=0.05$.

Fish community composition, using PERMANOVA, did not differ by stretch type $\left(F_{[2,4]}\right.$ $=1.02, p=0.455)$, year $\left(F_{[1,4]}=2.83, p=0.055\right)$, or the interaction $\left(F_{[2,4]}=0.75, p=0.678\right)$. Of the four additional PERMANOVAs, the lowest $\mathrm{p}$-value $\left(F_{[1,6]}=1.80, p=0.130\right)$ was achieved when the pre-restoration sample was labeled as a control and the post-restoration sample was labeled as a reference. Both pre- and post-restoration as references $\left(F_{[1,6]}=1.05, p=0.337\right)$, both pre and post as controls $\left(F_{[1,6]}=0.87, p=0.477\right)$, and pre as a reference and post as a control $\left(F_{[1,6]}=0.91, p=0.440\right)$ were not significant.

\section{Discussion}

\section{Rapid Visual Habitat Assessment}

The RVHA scored the reference stretches higher than the control stretches during both the summer 2009 and summer 2010 seasons. The largest differences between the stretch types involved riparian zone width and bank stability. Although the scores for individual stretches changed between the two seasons, the differences may be attributed to environmental conditions (such as the drought in early summer 2010) and the effects of the restoration on downstream stretches. The restoration stretch increased in score between the two years. Following restoration, substrate embeddedness and sediment deposition at the restoration stretch greatly decreased in score, due to the increased sedimentation associated with restoration efforts. However, the newly planted riparian vegetation and decrease in bank slope increased the scores of the bank-based metrics. In future years, the fine sediments covering the gravel and cobble in the restoration stretch should be swept away, and the stretch score should increase to levels seen in the reference stretches. 


\section{Macroinvertebrate Community Assessment}

The macroinvertebrate community at the restoration stretch following restoration efforts (July 2010) improved dramatically from the during-restoration community sampled less than three months prior to the post-restoration sampling. Although the metrics 'percent EPT' and 'percent dominant two taxa' did not improve from pre-restoration levels, all other metrics showed a comparative improvement within the stretch. 'Abundance', in particular, improved greatly from pre-restoration levels, and was far higher than that of any other site during the postrestoration sampling season. Other studies have also observed rapid increases in abundance following restoration efforts in medium to large rivers (Wallace 1990; Pederson et al. 2007). The Hilsenhoff Biotic Index value decreased at the restoration stretch (note that a decrease in the Hilsenhoff value indicates an increase in stretch health). The Hilsenhoff value has been a strong indicator of stream health in other studies, and appears to respond to acidification (Parsons et al. 2010) and changes in overall flow conditions (Armanini et al., in press) in addition to organic pollution levels (Hilsenhoff 1988).

Before restoration efforts, the restoration stretch more closely resembled the two control stretches than the two reference stretches for both sampling seasons (Summer and Winter). During restoration, the restoration stretch was significantly impacted by the resulting sedimentation and the localized macroinvertebrate community became temporarily impaired. Following restoration, although the stretch's rank sum score was still lower than in the two reference stretches, the restoration stretch score was more similar to those of the reference stretches than to those of the control stretches. Since the ultimate goal of restoration is to bring an impaired stretch closer to its natural state, this result is promising (Rosgen 1998).

The proportion of each functional feeding group (FFG) that corresponds to ideal natural conditions is a subject of debate (Mandaville 2002). Generally, an overall balance in these 
proportions indicates greater stream quality. The variation between FFG proportions was similar during the summer pre- and post-restoration samples. During restoration, the variation increased (specifically by an increase in the proportion of collector-gatherers). The low proportions of predators may indicate that the macroinvertebrate community was too sparse to support higher trophic levels, which in turn could reduce the health of the lower trophic levels (Nilsson et al. 2008).

Stenelmis (riffle beetle), the most common macroinvertebrate in the Cacapon, was relatively uncommon at the restoration site prior to restoration. Following restoration, Stenelmis numbers almost tripled those of the next most dominant taxon. Riffle beetle (Elmidae) abundance responds negatively to sedimentation and water pollution (Braccia \& Voshell 2007). Corydalus (hellgrammite) and aquatic mollusk genera (Corbicula, Pseudosuccinea, Leptoxis) were also considerably higher than pre- and during-restoration levels.

Following restoration, recolonization of lotic macroinvertebrates occurs through four distinct processes: downstream drift, upstream movement, persistence through disturbance, and aerial movement (Muotka et al. 2001). Drift is a recolonization mechanism that occurs in most macroinvertebrate species, although it is less common in heavier-bodied species such as shelled mollusks. Upstream movement also occurs in most macroinvertebrate species, although the rate of recolonization through upstream movement may be substantially lower than through drift if water flow is strong. A long, shallow, swift riffle immediately downstream from the restoration site may limit upstream movement.

Persistence through disturbance can occur in the hyporheic zone surrounding the stream channel, or in the stream bed sediment (Muotka et al. 2001). Operculate snails (Leptoxis included) can often close themselves off to environmental disturbance, reemerging once 
conditions become more favorable. Hyporheic recolonization at the Cacapon restoration site seems unlikely due to the high proportions of fine sediments (clay and silt) at the site; these sediments blanketed the site during the actual restoration process, cutting the stream channel off from the surrounding hyporheic sediments (Boulton 2007). In addition, taxa known to seek refuge in this zone (oligochaetes, plecopterans, chironomids) were not comparatively common following restoration (Boulton 2007).

Aerial recolonization occurs when the breeding adult forms of aquatic insects, hatching from other stretches of the stream or from nearby bodies of water, deposit eggs in the disturbed site (Blakely et al. 2006). Timing of emergence varies from taxon to taxon, and even within taxa. Therefore, the few months between restoration and the post-restoration sampling could breed this new generation of aquatic insects. Of the most dominant taxa found at the restoration site following restoration, many have winged adults (Hydropsychidae, Isonychiidae, Philopotamidae).

Although rapid recolonization from multiple sources can account for the increase in macroinvertebrate richness found at the restoration site following restoration, it cannot solely account for the increase in overall abundance. The electrofishing survey conducted at the restoration stretch suggested that the fish community post-restoration had high numbers of adults and juveniles of multiple insectivorous fish. It is quite possible that the fish community did not recolonize until after the macroinvertebrate community had time to reestablish free from vertebrate pressure, and therefore develop high abundance.

\section{Fish Community Assessment}

The bluntnose minnow (Pimephales notatus), a pollution-tolerant generalist species (Trebitz et al. 2003), was by far the most common species collected during electrofishing in the Cacapon River. The post-restoration stretch had particularly high numbers of this species. Eight 
species of centrarchids were captured, which corresponds to the number of species known to the Cacapon River (Constantz et al. 1995). Therefore, the electrofishing samples appeared representative of the species located within the stretches.

The Daniels (2002) IBI successfully differentiated the reference from control stretches during both pre- and post-restoration sampling seasons. Although few individual metrics successfully differentiated the reference from impaired stretches, the combination of all twelve did so. In both pre- and post-restoration samples, the restoration stretch scored between the reference and control stretches. The post-restoration stretch score was lower than the prerestoration score; however, all stretches scored lower during 2010 than they did in 2009. Due largely to increases in 'percent generalists', and decreases in 'abundance' and 'species richness', the during-restoration score was lower than that of other stretches. The anomalies seen prerestoration were no longer detected at the stretch following restoration.

These anomalies were quite common throughout the Cacapon River during the summers of 2009 and 2010; they were much less common during spring 2010 (during restoration). The vast majority of anomalies were identified as 'black spot disease', which is caused by a strigeid fluke parasite. A number of fluke species are known to parasitize fish; most require avian and gastropod hosts as well. Melanin pigments are deposited around the parasitic cysts, resulting in visible black spots (Berra and Au 1978). Black spot disease was only considered an anomaly if the parasites appeared hindering (at least four cysts on each fin).

The McCormick (2001) IBI was less successful in differentiating the impaired stretches from the reference stretches. Instead, it scored the upstream control stretch among or higher than the reference stretches both pre- and post-restoration. The exact reasons for this are unknown. Any IBI developed for as large a region as the Mid-Atlantic runs the risk of being less applicable 
to certain watersheds, which may have happened here. Fish are better indicators of overall stream health than macroinvertebrates, which are better indicators of localized stream health (Berkman \& Rabeni 1986; Barbour et al. 1999). Therefore, the McCormick IBI may be scoring a much larger stretch of the river than was actually sampled, thereby masking the localized impairments.

As in the Daniels IBI, the restoration stretch scored similarly pre- and post-restoration, and scored far lower during restoration. All three stretches sampled during restoration showed similar (though less extreme) decreases in overall IBI score. Of these, the upstream control seemed to recover fastest; the downstream control remained fairly low during the postrestoration sampling. The restoration stretch showed recovery intermediate of these two.

The water in the restoration stretch during restoration was extremely turbid, and the sediment causing the turbidity could be seen as far downstream as the downstream control stretch. Shortly after restoration, the suspended sediments returned to normal levels, although the increased turbidity persisted at the restoration stretch longer than at the downstream stretches. A number of sedimentation-tolerant fish species; including yellow bullhead (Ameiurus natalis), white sucker (Catostomus commersoni), and bluntnose minnow; became more common at the restoration and downstream stretches following restoration. Only one intolerant species, the rosyface shiner (Notropis rubellus), increased in these stretches following restoration (Larsen et al. 1986). Therefore, given the newly established macroinvertebrate community and the short time frame during which the restoration stretch was clear of fine sediment, the rapid recovery of the fish community following restoration was promising. While future surveys are necessary to determine long-term trends, the immediate results (only 3 months following procedures) show positive improvements in the health of the aquatic communities. 


\section{Implications for Practice}

- It is important to locate and sample multiple impaired control and natural reference stretches in addition to the targeted restoration stretch(es), and confirm using appropriate analyses or indices that these stretches match their labels

- At the scale of this restoration project, aquatic macroinvertebrates were likely stronger indicators of the localized stream health than were fishes; however, sampling fish communities allowed inferences to be drawn regarding the larger-scale effects of the restoration project

- Metrics measuring evenness (such as 'percent dominant taxa') are often misleading when assessing the short-term responses of a stretch to restoration efforts. Different taxa recolonize disturbed areas at different rates, and an abundance of sediment intolerant taxa following restoration is promising (as was the case with Stenelmis in our study)

\section{Acknowledgments}

Funding and logistical support was provided by the National Fish and Wildlife Foundation, The Chesapeake Bay Trust, National Oceanic and Atmospheric Administration, FishAmerica Foundation, Canaan Valley Institute, and the Cacapon and Lost Rivers Land Trust. Thank you to Dr. George Merovich for statistical assistance and the local landowners (Mr. Frye, Mr. Rudolph, and Mr. White) for making this project possible. Finally, thank you to Jonathon Pitchford, Crissa Cooey, Tristan Gingerich, and Katy and Noah McCoard for field assistance. This is scientific article xxxx of the West Virginia University Agricultural and Forestry Experiment Station. 


\section{LITERATURE CITED}

Adams, S. M., W. R. Hill, M. J. Peterson, M. G. Ryon, J. G. Smith, and A. J. Stewart. 2002. Assessing recovery in a stream ecosystem: applying multiple chemical and biological endpoints. Ecological Applications 12:1510-1527.

Alexander, G. G., and J. D. Allan. 2007. Ecological success in stream restoration: case studies from the Midwestern United States. Environmental Management 40:245-255.

Angradi, T.R. 1999. Fine sediment and macroinvertebrate assemblages in Appalachian streams: a field experiment with biomonitoring applications. Journal of the North American Benthological Society 18:49-66.

Armanini, D. G., N. Horrigan, W. A. Monk, D. L. Peters, and D. J. Baird. In press. Development of a benthic macroinvertebrate flow sensitivity index for Canadian rivers. River Research and Applications doi:10.1002.rra.1389.

Arthington, A. H., R. J. Naiman, M. E. McClain, and C. Nilsson. 2010. Preserving the biodiversity and ecological services of rivers: new challenges and research opportunities. Freshwater Biology 55:1-16.

Barbour, M. T., J. Gerritsen, G. E. Griffith, R. Frydenborg, E. McCarron, J. S. White, and M. L. Bastian. 1996. A framework for biological criteria for Florida streams using benthic macroinvertebrates. Journal of the North American Benthological Society 15:185-211.

Barbour, M. T., J. Gerritsen, B. D. Snyder, and J. B. Stribling. 1999. Rapid bioassessment protocols for use in streams and wadeable rivers: periphyton, benthic macroinvertebrates and fish, second edition. EPA 841-B-99-002. U.S. Environmental Protection Agency, Office of Water, Washington, D.C.

Berkman, H. E, and C. F. Rabeni. 1986. Biomonitors of stream quality in agricultural areas: fish versus invertebrates. Environmental Management 10:413-419. 
Berra, T. M., and R. J. Au. 1978. Incidence of black spot disease in fishes in Cedar Fork Creek, Ohio. Ohio Journal of Science 78:318-322.

Blakely, T. J., J. S. Harding, A. R. McIntosh, and M. J. Winterbourn. 2006. Barriers to the recovery of aquatic insect communities in urban streams. Freshwater Biology 51:16341645.

Boulton, A. J. 2007. Hyporheic rehabilitation in rivers: restoring vertical connectivity. Freshwater Biology 52:632-650.

Braccia, A., and J. R. Voshell Jr. 2007. Benthic macroinvertebrate responses to increasing levels of cattle grazing in Blue Ridge Mountain streams, Virginia, USA. Environmental Monitoring and Assessment 131:185-200.

Carline, R. F., and M. C. Walsh. 2007. Responses to riparian restoration in the Spring Creek watershed, central Pennsylvania. Restoration Ecology 15:731-742.

Clarke, K. R. 1993. Non-parametric multivariate analysis of changes in community structure. Australian Journal of Ecology 18:117-143.

Constantz, G., N. Ailes, and D. Malakoff. 1995. Portrait of a river: the ecological baseline of the Cacapon River. Pine Cabin Run Ecological Laboratory, High View, West Virginia.

Daniels, R. A., K. Riva-Murray, D. B. Halliwell, D. L. Vana-Miller, and M. D. Bilger. 2002. An index of biological integrity for northern mid-Atlantic slope drainages. Transactions of the American Fisheries Society 131:1044-1060.

Gilles, N. 2009. Cacapon Institute, High View, West Virginia (available from http://www.cacaponinstitute.org) accessed 21 March 2009.

Hilsenhoff, W. L. 1988. Rapid field assessment of organic pollution with a family-level biotic index. Journal of the North American Benthological Society 7:65-68. 
Johnson, P. A., R. D. Hey, E. R. Brown, D. L. Rosgen. 2002. Stream restoration in the vicinity of bridges. Journal of the American Water Resources Association 38:55-67.

Johnson, T. D., T. E. Kolb, and A. L. Medina. 2010. Do riparian plant community characteristics differ between Tamarix (L.) invaded and non-invaded sites on the upper Verde River, Arizona? Biological Invasions 12:2487-2497.

Keystone Stream Team. 2003. Guidelines for Natural Stream Channel Design for Pennsylvania Waterways. Alliance for Chesapeake Bay and Pennsylvania Department of Environmental Protection, Williamsport, Pennsylvania.

Kondolf, G.M., and E. R. Micheli. 1995. Evaluating stream restoration projects. Environmental Management 19:1-15.

Larsen, D. P., J. M. Omernik, R. M. Hughes, C. M. Rohm, T. R. Whittier, A. J. Kinney, A. L. Gallant, and D. R. Dudley. 1986. Correspondence between spatial patterns in fish assemblages in Ohio streams and aquatic ecoregions. Environmental Management 10:815-825.

Lenat, D. R. 1988. Water quality assessment of streams using a qualitative collection method for benthic macroinvertebrates. Journal of the North American Benthological Society 7:222233.

Lepori, F., D. Palm, E. Brannas, and B. Malmqvist. 2005. Does restoration of structural heterogeneity in streams enhance fish and macroinvertebrate diversity? Ecological Applications 15:2060-2071.

Mandaville, S. M. 2002. Benthic Macroinvertebrates in Freshwaters-Taxa Tolerance Values, Metrics, and Protocols. Soil \& Water Conservation Society of Metro Halifax, Nova 
Scotia, Canada (available from http://www.chebucto.ns.ca/ccn/info/Science/SWCS/H1/tolerance.pdf) accessed 2 Feb 2011.

McCormick, F. H., R. M. Hughes, P. R. Kaufmann, D. V. Peck, J. L. Stoddard, and A. T. Herlihy. 2001. Development of an index of biotic integrity for the Mid-Atlantic Highlands region. Transactions of the American Fisheries Society 130:857-877.

Miller, S. W., P. Budy, and J. C. Schmidt. 2010. Quantifying macroinvertebrate responses to instream habitat restoration: applications of meta-analysis to river restoration. Restoration Ecology 18:8-19.

Moerke, A. H., Gerard, K. J., Latimore, J. A., Hellenthal, R. A., and Lamberti, G. A. 2004. Restoration of an Indiana, USA, stream: Bridging the gap between basic and applied lotic ecology. Journal of the North American Benthological Society 23:647-660.

Muotka, T., R. Paavola, A. Haapala, M. Novikmee, and P. Laasonen. 2001. Long-term recovery of stream habitat structure and benthic invertebrate communities from in-stream restoration. Biological Conservation 105:243-253.

Nagle, G. 2007. Evaluating ‘natural channel design’ stream projects. Hydrological Processes 21:2539-2545.

Nilsson, E., K. Olsson, A. Persson, P. Nyström, G. Svensson, and U. Nilsson. 2008. Effects of stream predators on the prey community and ecosystem attributes. Oecologia 157:641651.

Opperman, J. J., and A. M. Merenlender. 2004. The effectiveness of riparian restoration for improving instream fish habitat in four hardwood-dominated California streams. North American Journal of Fisheries Management 24:822-834. 
Parsons, B. G., S. A. Watmough, P. J. Dillon, and K. M. Somers. 2010. Relationships between lake water chemistry and benthic macroinvertebrates in the Athabasca Oil Sands region, Alberta. Journal of Limnology 69:118-125.

Peckarsky, B. L., P. R. Fraissinet, M. A. Penton, and D. J. Conklin, Jr. 1990. Freshwater macroinvertebrates of northeastern North America. Comstock Publishing Associates, Ithaca, New York.

Pederson, M. L., N. Friberg, J. Skriver, A. Baattrup-Pederson, and S. E. Larsen. 2007. Restoration of Skjern River and its valley - short-term effects on river habitats, amcrophytes and macroinvertebrates. Ecological Engineering 30:145-156.

Radspinner, R. R., P. Diplas, A. F. Lightbody, and F. Sotiropoulos. 2010. River training and ecological enhancement potential using in-stream structures. Journal of Hydraulic Engineering 136:967-980.

Rosgen, D. L. 1994. A classification of natural rivers. Catena 22:169-199.

Rosgen, D. L. 1998. The Reference Reach-A Blueprint for Natural Channel Design. In: Proceedings of the American Society of Civil Engineers, Restoration of Wetlands and Rivers, Denver, Colorado.

Ryder, R. T., R. D. Crangle, M. H. Trippi, C. S. Swezey, E. E. Lentz, E. L. Rowan, and R. S. Hope. 2009. Geologic cross section D-D' through the Appalachian Basin from the Findlay Arch, Sandusky County, Ohio, to the Valley and Ridge Province, Hardy County, West Virginia. United States Geologic Survey, Reston, Virginia.

Selvakumar, A., T. P. O’Connor, and S. D. Struck. 2010. Role of stream restoration on improving benthic macroinvertebrates and in-stream water quality in an urban watershed: case study. Journal of Environmental Engineering 136:127-139. 
Spanhoff, B., and J. Arle. 2007. Setting attainable goals of stream habitat restoration from a macroinvertebrate view. Restoration Ecology 15:317-320.

Strager, M.P., J.T. Anderson, J.D. Osbourne, and R. Fortney. 2011. A three-tiered framework to select, prioritize, and evaluate potential wetland and stream mitigation banking sites. Wetlands Ecology and Management 19:1-18.

Sweeney, B. W., T. L. Bott, J. K. Jackson, L. A. Kaplan, J. D. Newbold, L. J. Standley, W.C. Hession, R.J. Horwitz, and M.G. Wolman. 2004. Riparian deforestation, stream narrowing, and loss of stream ecosystem services. Proceedings of the National Academy of Sciences of the United States of America 101:14132-14137.

Teels, B. M., C. A. Rewa, and J. Myers. 2006. Aquatic condition response to riparian buffer establishment. Wildlife Society Bulletin 34:927-935.

Tetra Tech, Inc. 2000. A stream condition index for West Virginia wadeable streams. Owings Mills, MD.

Trebitz, A. S., B. H. Hill, and F. H. McCormick. 2003. Sensitivity of indices of biotic integrity to simulated fish assemblage changes. Environmental Management 32:499-515.

Wallace, J. B. 1990. Recovery of lotic macroinvertebrate communities from disturbance. Environmental Management 14:605-620.

Wildsmith, M. D., T. H. Rose, I. C. Potter, R. M. Warwick, K. R. Clarke, and F. J. Valesini. 2009. Changes in the benthic macroinvertebrate fauna of a large microtidal estuary following extreme modifications aimed at reducing eutrophication. Marine Pollution Bulletin 58:1250-1262. 
Table 1: Rapid visual habitat assessment (RVHA) metrics for riffle-dominated rivers based on Barbour et al. (1999).

\begin{tabular}{|c|c|}
\hline Parameter & Explanation \\
\hline $\begin{array}{l}\text { Epifaunal substrate and } \\
\text { available cover }\end{array}$ & $\begin{array}{l}\text { Relative quantity and variety of natural structures (large rocks, coarse } \\
\text { woody debris, undercut banks), used as refugia and feeding/breeding } \\
\text { areas for aquatic taxa }\end{array}$ \\
\hline Embeddedness & $\begin{array}{l}\text { Extent to which gravel, cobble, and boulders are covered by fine } \\
\text { sediments in the stream bed }\end{array}$ \\
\hline $\begin{array}{l}\text { Velocity and depth } \\
\text { combinations }\end{array}$ & $\begin{array}{l}\text { Presence or absence of the four regimes: slow+deep, slow+shallow, } \\
\text { fast+deep, and fast+shallow }\end{array}$ \\
\hline Sediment deposition & $\begin{array}{l}\text { Measures the amount of fine sediments that have accumulated in pools, } \\
\text { and the changes to the stream bed due to this deposition }\end{array}$ \\
\hline Channel flow status & $\begin{array}{l}\text { Degree to which the channel is filled with water; associated with the } \\
\text { exposure of substrate and presence of point bars }\end{array}$ \\
\hline Channel alteration & $\begin{array}{l}\text { Measures large-scale changes to the shape of the stream channel; } \\
\text { associated with presence of artificial bank stabilizers, riprap, bridges, } \\
\text { and full-channel diversion/straightening }\end{array}$ \\
\hline Frequency of riffles & $\begin{array}{l}\text { Measures the sequence of distinct riffles in the channel; in streams } \\
\text { where distinct riffles are uncommon, frequency of bends (sinuosity) } \\
\text { can substitute for this metric }\end{array}$ \\
\hline Bank stability & $\begin{array}{l}\text { Degree to which the banks are eroding, and average bank slope } \\
\text { (steep versus gently sloping) }\end{array}$ \\
\hline Vegetative protection & $\begin{array}{l}\text { Amount of established vegetation covering the near-stream portion } \\
\text { of the riparian zone, which provides shade, bank stabilization, and } \\
\text { nutrient uptake }\end{array}$ \\
\hline Riparian vegetative zone & $\begin{array}{l}\text { Measures the width of the riparian zone, composed of natural } \\
\text { vegetation which acts as a buffer for runoff and erosion }\end{array}$ \\
\hline
\end{tabular}


Table 2: Names, explanations, justifications, and scoring of aquatic macroinvertebrate metrics used to assess sampling stretch health in the Cacapon River, WV, 2009-2010. As stretch health improves, positive (Pos) scoring metrics increase and negative (Neg) scoring metrics decrease.

\begin{tabular}{|c|c|c|c|}
\hline Metric & Explanation & Justification & Scoring \\
\hline Total genera & $\begin{array}{l}\text { A count of all genera identified; } \\
\text { if a taxon cannot be reduced to } \\
\text { genus-level, it is assumed to } \\
\text { have one genus represented } \\
\text { within the site }\end{array}$ & $\begin{array}{l}\text { Identifying samples to family } \\
\text { level may not adequately } \\
\text { summarize the diversity found } \\
\text { within a study site }\end{array}$ & Pos \\
\hline Total taxa & $\begin{array}{l}\text { A count of all taxa identified; } \\
\text { this is family for all insects and } \\
\text { mollusks and order for most } \\
\text { other groups }\end{array}$ & $\begin{array}{l}\text { This metric corresponds to } \\
\text { overall macroinvertebrate } \\
\text { richness, which is generally a } \\
\text { good measure of site health }\end{array}$ & Pos \\
\hline Total EPT taxa & $\begin{array}{l}\text { A count of all families within } \\
\text { Plecoptera, Ephemeroptera, and } \\
\text { Trichoptera }\end{array}$ & $\begin{array}{l}\text { EPT taxa are, in general, } \\
\text { intolerant of organic pollution } \\
\text { and sedimentation }\end{array}$ & Pos \\
\hline$\%$ EPT taxa & $\begin{array}{l}\text { The percent of collected } \\
\text { individuals within EPT taxa }\end{array}$ & As above & Pos \\
\hline$\%$ Chironomidae & $\begin{array}{l}\text { The percent of collected } \\
\text { individuals within the family } \\
\text { Chironomidae }\end{array}$ & $\begin{array}{l}\text { Chironomidae tends to } \\
\text { increase in abundance as } \\
\text { organic pollution increases }\end{array}$ & $\mathrm{Neg}$ \\
\hline$\%$ top two taxa & $\begin{array}{l}\text { The percent of collected } \\
\text { individuals within the most } \\
\text { dominant two taxa (as defined } \\
\text { under 'total taxa' above) }\end{array}$ & $\begin{array}{l}\text { This metric corresponds to } \\
\text { overall macroinvertebrate } \\
\text { evenness, which is generally a } \\
\text { good measure of site health }\end{array}$ & $\mathrm{Neg}$ \\
\hline Hilsenhoff index & $\begin{array}{l}\text { Averages the tolerance values } \\
\text { associated with } \\
\text { macroinvertebrate taxa; values } \\
\text { from Mandaville (2002) range } \\
\text { from } 0 \text { (intolerant) to } 10\end{array}$ & $\begin{array}{l}\text { The Hilsenhoff Biotic Index } \\
\text { predicts an overall tolerance of } \\
\text { the community to organic } \\
\text { stressors }\end{array}$ & $\mathrm{Neg}$ \\
\hline Abundance & $\begin{array}{l}\text { A count of all individuals } \\
\text { collected; not weighted based on } \\
\text { biomass }\end{array}$ & $\begin{array}{l}\text { In general, healthy sites can } \\
\text { support greater numbers of } \\
\text { macroinvertebrates than can } \\
\text { impaired sites }\end{array}$ & Pos \\
\hline Rank Sum & $\begin{array}{l}\text { Each site is given a rank relative } \\
\text { to all other sites within the } \\
\text { sampling season for each metric } \\
\text { above; the rank sum is a sum } \\
\text { across all metrics }\end{array}$ & $\begin{array}{l}\text { Each individual metric has } \\
\text { exceptions that mask the true } \\
\text { quality of the site; the rank } \\
\text { sum considers all metrics } \\
\text { simultaneously }\end{array}$ & \\
\hline
\end{tabular}


Table 3: Names, explanations, and scoring of fish metrics used in the Daniels et al. (2002) (DS) and McCormick et al. (2001) (MC) indices of biotic integrity, used to assess sampling stretch health on the Cacapon River, WV, 2009-2010. As stretch health improves, positive (Pos) scoring metrics increase and negative (Neg) scoring metrics decrease.

\begin{tabular}{|c|c|c|c|}
\hline IBI & Metric & Explanation & Scoring \\
\hline DS & Total species & $\begin{array}{l}\text { Provides a measure of richness, which } \\
\text { decreases with degradation }\end{array}$ & Pos. \\
\hline DS & Benthic insectivorous spp. & $\begin{array}{l}\text { Many species need clean substrate for } \\
\text { feeding and reproduction }\end{array}$ & Pos. \\
\hline DS & Total water column spp. & Respond negatively to pool degradation & Pos. \\
\hline DS & Total terete minnow spp. & $\begin{array}{l}\text { Most are long-lived, widely-distributed, } \\
\text { and intolerant of degradation }\end{array}$ & Pos. \\
\hline DS & Percent dominant & Provides a measure of evenness & Neg. \\
\hline DS & Percent Catostomus & $\begin{array}{l}\text { White suckers are tolerant, and increase } \\
\text { in abundance in degraded streams }\end{array}$ & Neg. \\
\hline DS & Percent generalist & $\begin{array}{l}\text { Generalists often become dominant in } \\
\text { degraded streams }\end{array}$ & Neg. \\
\hline DS & Percent insectivores & Reflects the availability of invertebrate prey & Pos. \\
\hline DS & Percent top carnivore & $\begin{array}{l}\text { Top predators are only present in healthy, } \\
\text { diverse streams }\end{array}$ & Pos. \\
\hline DS & Total individuals & Provides a measure of abundance & Pos. \\
\hline DS & $\begin{array}{l}\text { Percent spp. with multiple } \\
\text { size classes }\end{array}$ & Provides a measure of local recruitment & Pos. \\
\hline DS & Percent with anomalies & Fish condition is related to degradation level & Neg. \\
\hline $\mathrm{MC}$ & $\begin{array}{l}\text { Total non-tolerant } \\
\text { Cyprinids }\end{array}$ & $\begin{array}{l}\text { Declines due to degradation, especially due } \\
\text { to acidification }\end{array}$ & Pos. \\
\hline $\mathrm{MC}$ & Native benthic spp. & $\begin{array}{l}\text { Many species need clean substrate for } \\
\text { feeding reproduction }\end{array}$ & Pos. \\
\hline $\mathrm{MC}$ & Total sensitive spp. & $\begin{array}{l}\text { These species are the first to disappear from } \\
\text { degraded streams }\end{array}$ & Pos. \\
\hline $\mathrm{MC}$ & Percent Cottidae & $\begin{array}{l}\text { Responds negatively to sedimentation and } \\
\text { nutrient loading }\end{array}$ & Pos. \\
\hline $\mathrm{MC}$ & Percent tolerant & $\begin{array}{l}\text { Tolerant species often become dominant in } \\
\text { degraded streams }\end{array}$ & Neg. \\
\hline $\mathrm{MC}$ & Percent non-natives & $\begin{array}{l}\text { Measures the degree to which a site is } \\
\text { affected by biological "pollution" }\end{array}$ & Neg. \\
\hline MC & $\begin{array}{l}\text { Percent piscivores or } \\
\text { piscivores/invertivores }\end{array}$ & $\begin{array}{l}\text { Reflects the prey available to high trophic } \\
\text { levels }\end{array}$ & Pos. \\
\hline $\mathrm{MC}$ & $\begin{array}{l}\text { Percent macro- } \\
\text { omnivores }\end{array}$ & $\begin{array}{l}\text { Trophic generalists often become dominant } \\
\text { in degraded streams }\end{array}$ & Neg. \\
\hline $\mathrm{MC}$ & Percent gravel spawners & These species require clean gravel to spawn & Pos. \\
\hline
\end{tabular}


Table 4: Pearson's correlation coefficients and associated permutational p-values (1000 randomizations) for relations between macroinvertebrate index of biotic integrity metrics and nonmetric multidimensional scaling (NMDS) ordination for the macroinvertebrate community sampled during the summers of 2009 and 2010 from the Cacapon River, WV. An asterisk indicates significance at $\alpha=0.05$. Two asterisks indicates significance at $\alpha=0.01$.

\begin{tabular}{lcc}
\hline Metric & Vector $^{2}$ & $p$-value \\
\hline Total genera & 0.458 & 0.119 \\
Total taxa & 0.348 & 0.212 \\
EPT taxa & 0.425 & 0.143 \\
Percent EPT & 0.114 & 0.658 \\
Percent Chironomidae & 0.580 & $0.044 *$ \\
Percent dominant 2 taxa & 0.584 & $0.040 *$ \\
Hilsenhoff Biotic Index & 0.931 & $0.001 * *$ \\
Abundance & 0.664 & $0.025 *$ \\
\hline
\end{tabular}




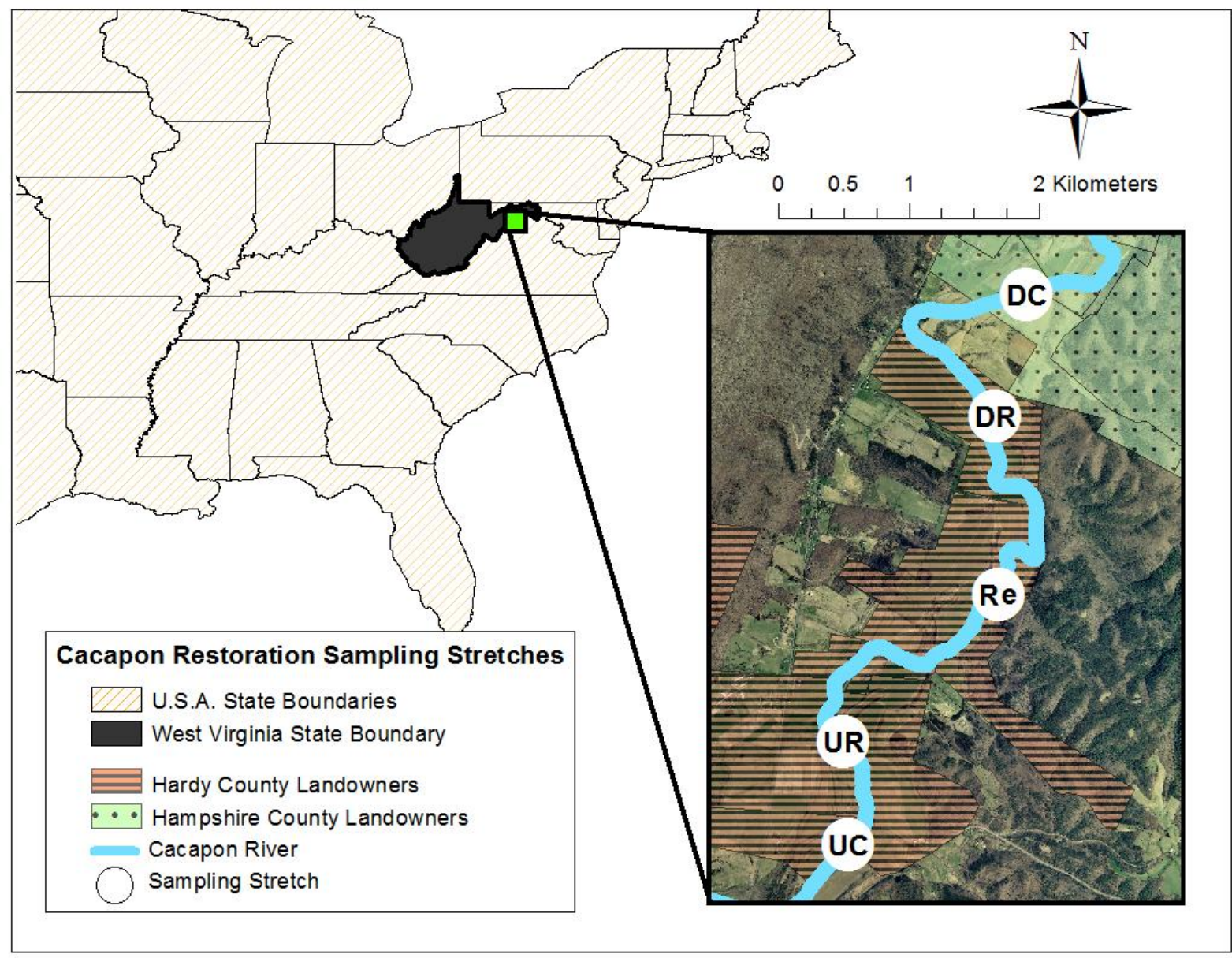

Figure 1: Map of the restoration stretch, located in Hardy and Hampshire Counties, West Virginia in the Northeastern United States. Upstream control (impaired stretch, but not receiving restoration) denoted ' $U C$ ', downstream control denoted 'DC'. Upstream reference (unimpaired, natural stretch) denoted 'UR', downstream reference denoted 'DR'. The restoration stretch denoted 'Re'. 


\section{Overall EPT Abundance}

Total Richness $=30$ families

Total Abundance $=15,713$

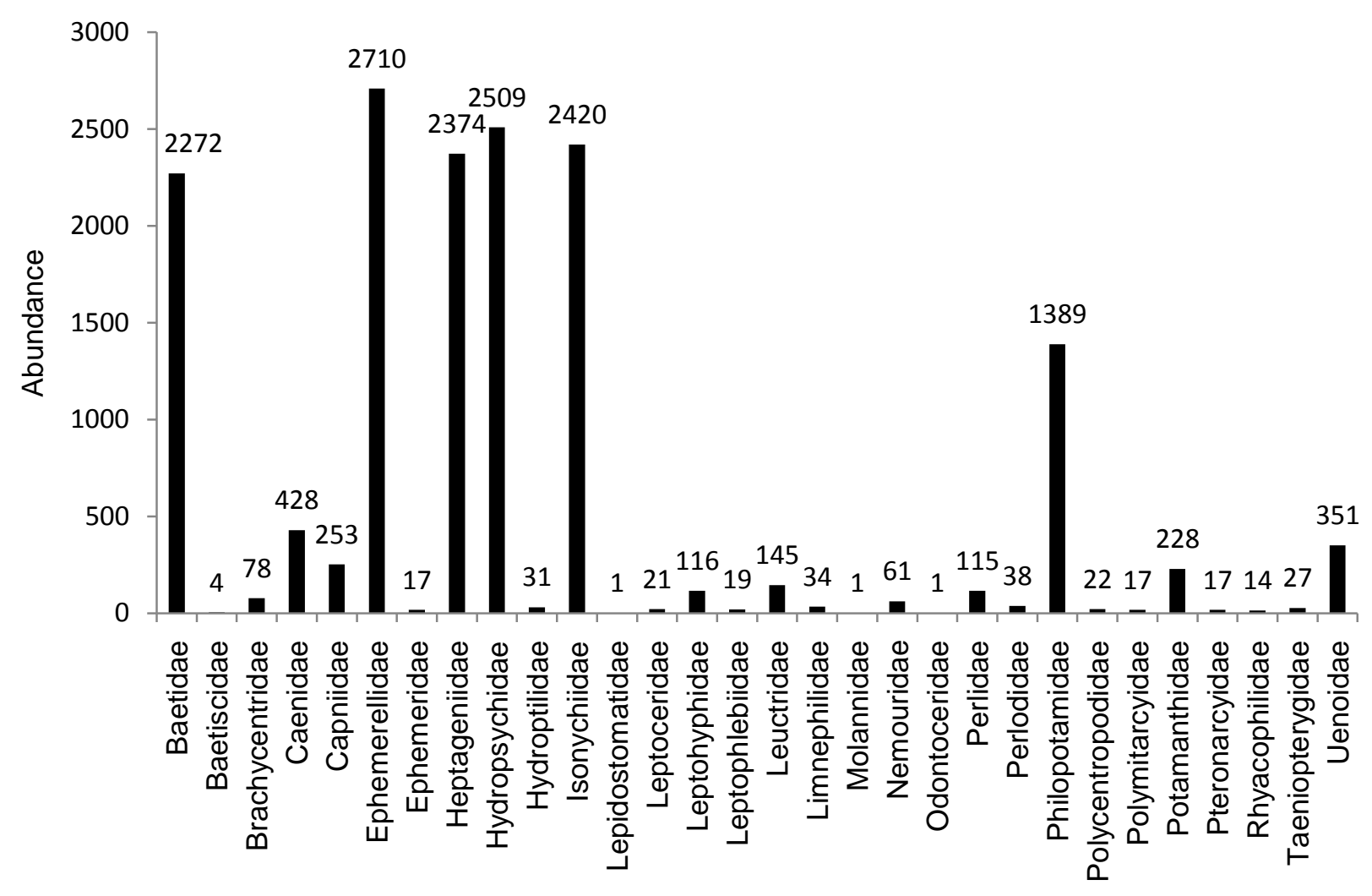

Figure 2: Overall abundances of Ephemeroptera, Plecoptera, and Trichoptera (EPT) taxa

collected from the Cacapon River from all five stretches during all four sampling seasons, 20092010 . 


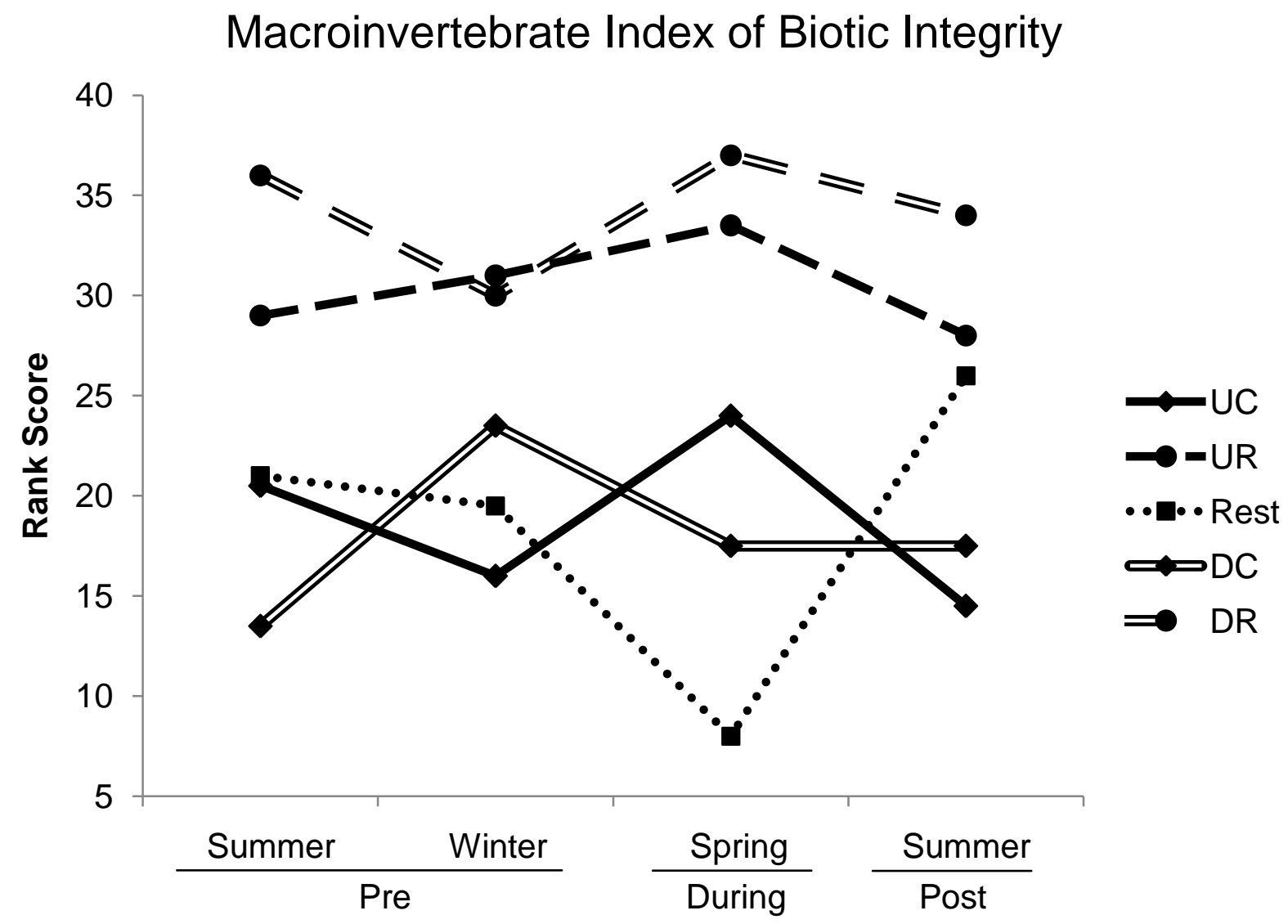

Figure 3: Cacapon River restoration, control, and reference sampling stretch rank sum scores for macroinvertebrate modified index of biotic integrity (IBI) across all sampling seasons: prerestoration (two samples), during restoration, and post-restoration. Upstream control (impaired stretch, but not receiving restoration) denoted ' $U C$ ', downstream control denoted 'DC', upstream reference (unimpaired, natural stretch) denoted 'UR', and downstream reference denoted 'DR'. The restoration stretch is denoted as 'Rest'. 


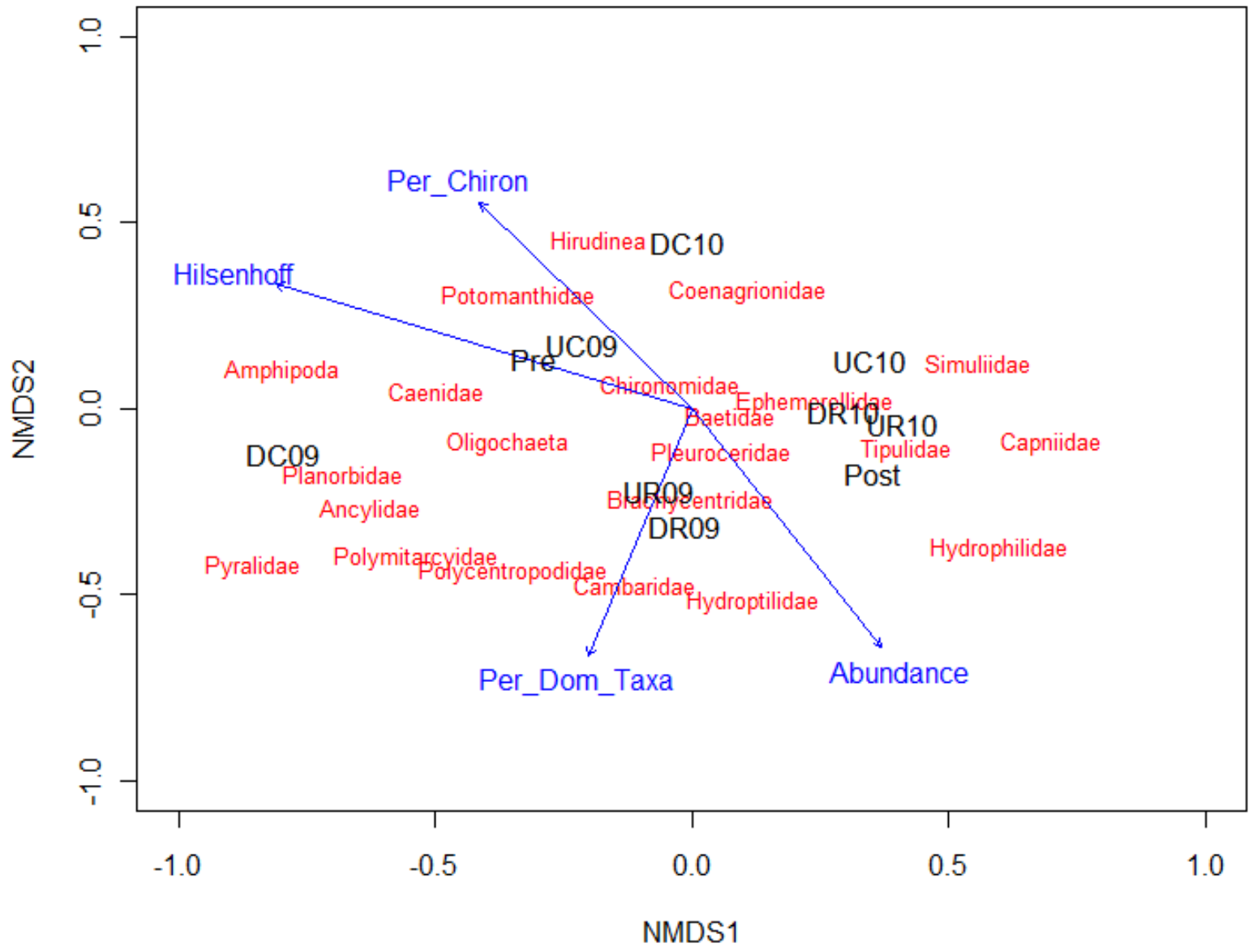

Figure 4: Nonmetric multidimensional scaling (NMDS) ordination plot for aquatic macroinvertebrate communities at all sampling stretches (stress $=10.6$ for 2-dimensional solution). Stretches are labeled by treatment category: upstream control (impaired stretch, but not receiving restoration) denoted ' $\mathrm{UC}$ '; downstream control denoted ' $\mathrm{DC}$ '; upstream reference (unimpaired, natural stretch) denoted 'UR'; and downstream reference denoted 'DR'. 'Pre' denotes the restoration stretch prior to restoration, and 'Post' denotes the restoration stretch after restoration. Selected macroinvertebrate taxa are positioned in the ordination as weighted averages. Vector lengths indicate relative correlative strength of macroinvertebrate community metrics ( $\mathrm{p} \leq 0.05 ; 1000$ permutations). 


\section{Daniels et al. (2002) IBI}

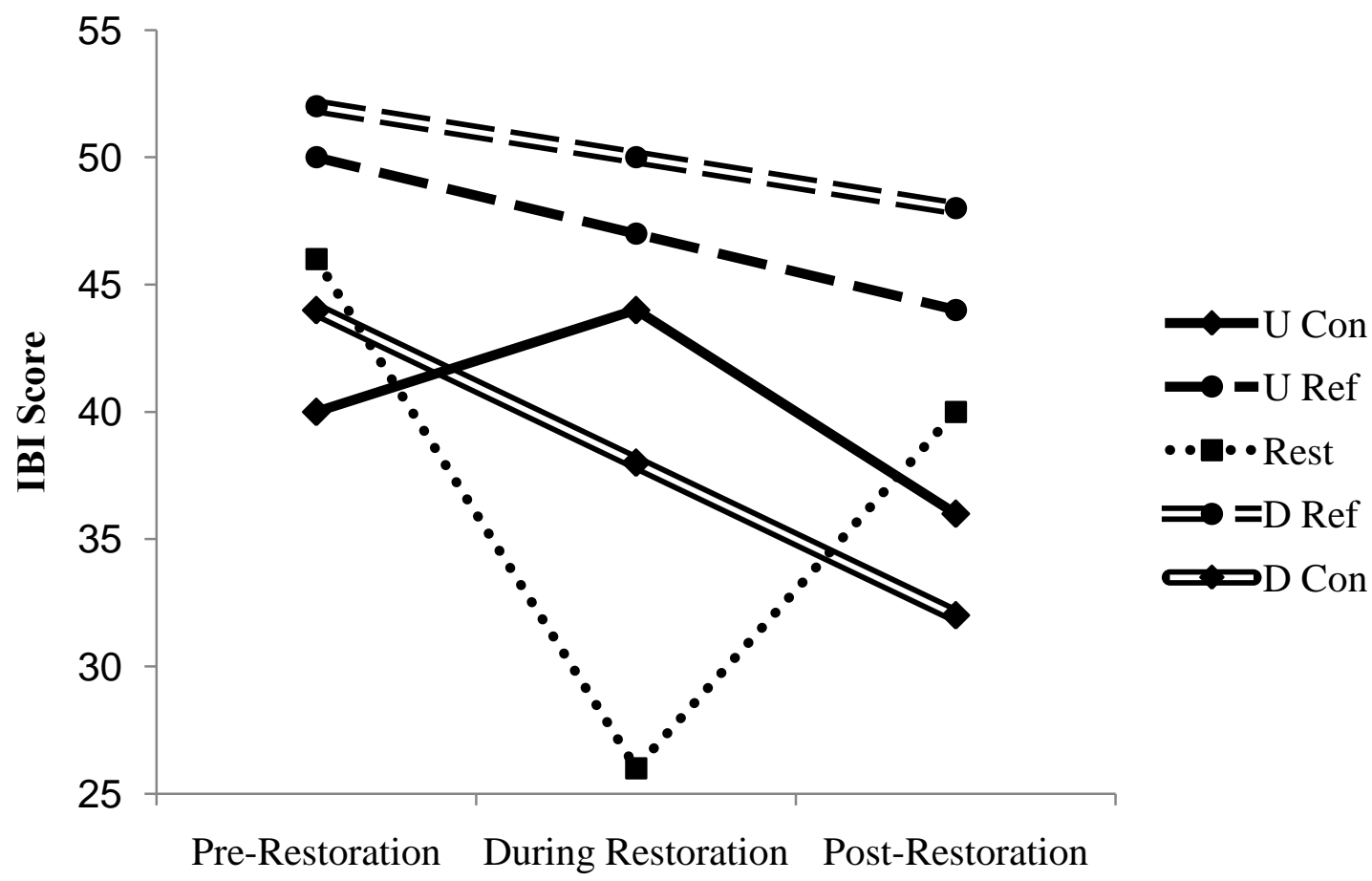

Figure 5: Cacapon River restoration, control, and reference sampling stretch for Daniels et al. (2002) fish index of biotic integrity (IBI) scores across all sampling seasons. Upstream control (impaired stretch, but not receiving restoration) denoted 'U Con', downstream control denoted 'D Con', upstream reference (unimpaired, natural stretch) denoted 'U Ref', and downstream reference denoted 'D Ref'. The restoration stretch is denoted as 'Rest'. 


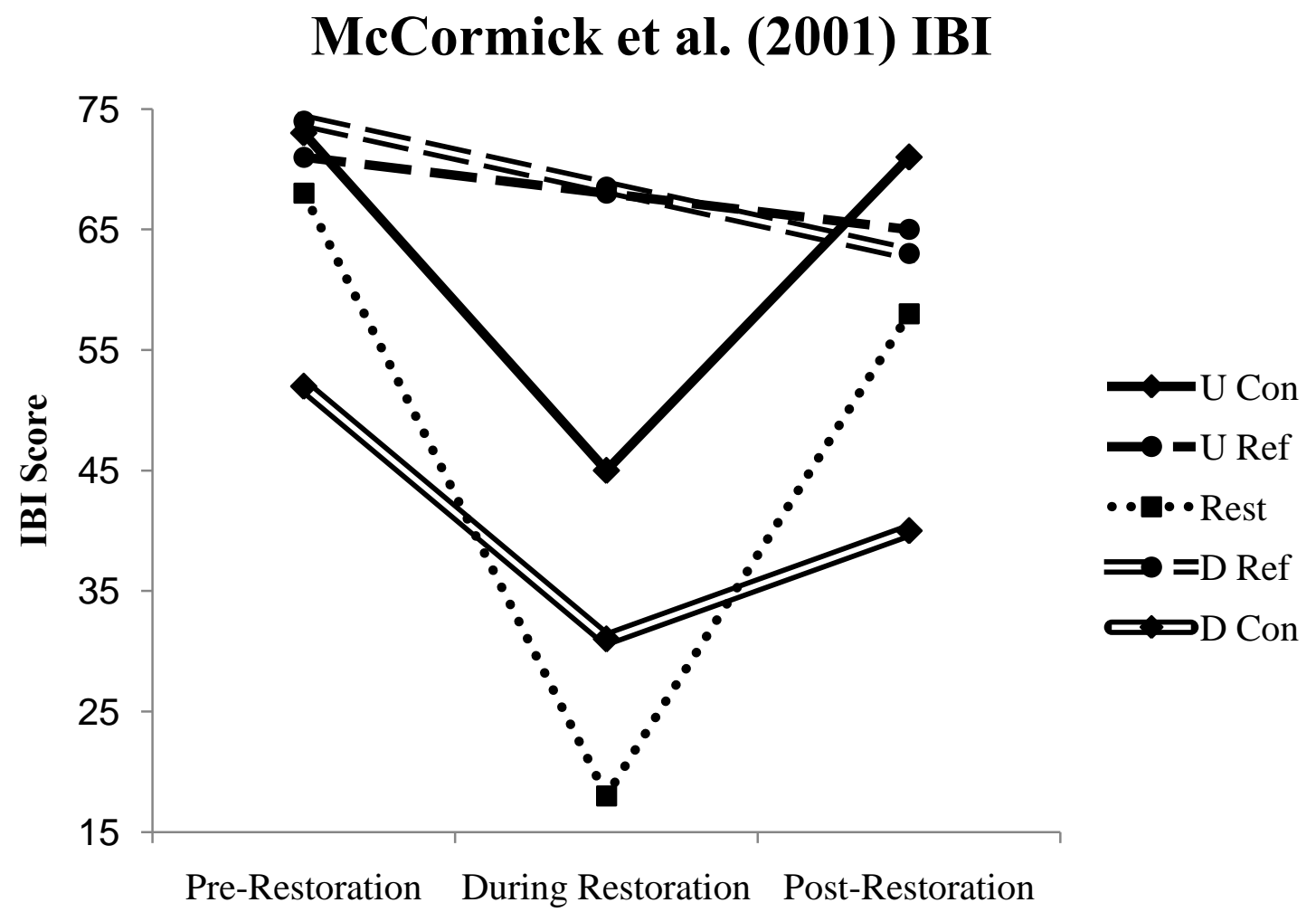

Figure 6: Cacapon River restoration, control, and reference sampling stretch for McCormick et al. (2001) fish index of biotic integrity (IBI) scores across all sampling seasons. Upstream control (impaired stretch, but not receiving restoration) denoted 'U Con', downstream control denoted 'D Con', upstream reference (unimpaired, natural stretch) denoted 'U Ref', and downstream reference denoted 'D Ref'. The restoration stretch is denoted as 'Rest'. 


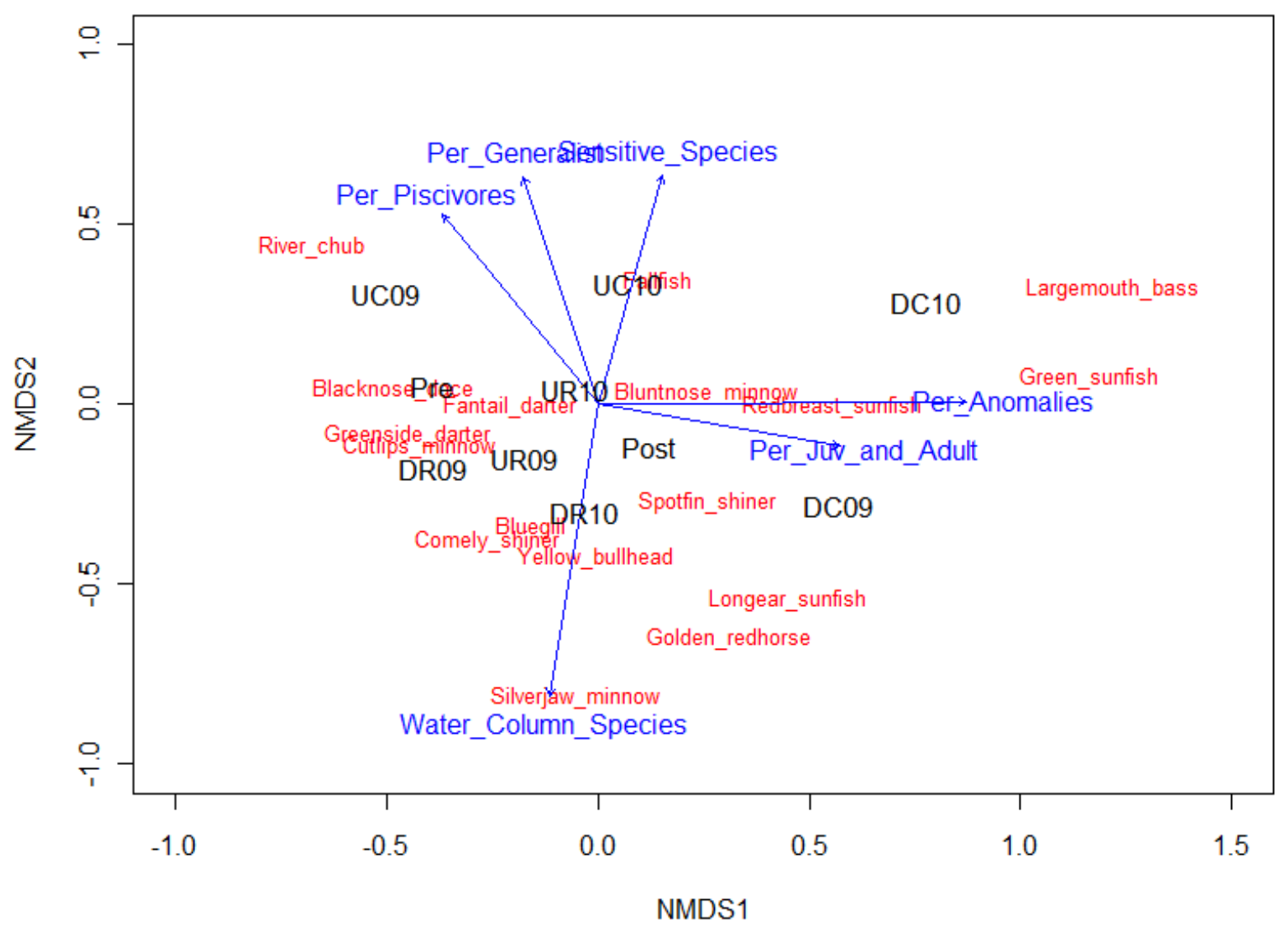

Figure 7: Nonmetric multidimensional scaling (NMDS) ordination plot for fish communities at all sampling stretches (stress $=11.3$ for 2-dimensional solution). Stretches are labeled by treatment category: upstream control (impaired stretch, but not receiving restoration) denoted 'UC'; downstream control denoted 'DC'; upstream reference (unimpaired, natural stretch) denoted 'UR'; and downstream reference denoted 'DR'. 'Pre' denotes the restoration stretch prior to restoration, and 'Post' denotes the restoration stretch after restoration. Selected fish species are positioned in the ordination as weighted averages. Vector lengths indicate relative correlative strength of fish community metrics based on an index of biotic integrity suggested by Daniels et al. (2002) ( $\mathrm{p} \leq 0.25 ; 1000$ permutations). 
Chapter III

\title{
Male Centrarchidae Nesting Behavior in the Cacapon River, West Virginia
}

\author{
Stephen M. Selego ${ }^{1}$, George T. Merovich, Jr. ${ }^{1}$, Stuart A. Welsh ${ }^{2}$, and James T. Anderson ${ }^{1,3}$ \\ ${ }^{1}$ Division of Forestry and Natural Resources, Wildlife and Fisheries Resources Program, \\ West Virginia University, PO Box 6125, Percival Hall, Morgantown, WV 26506 \\ ${ }^{2}$ WV Cooperative Fish and Wildlife Research Unit, West Virginia University, Morgantown, WV \\ 26506 \\ ${ }^{3}$ address correspondence to James T. Anderson, Ph.D., Environmental Research Center, West \\ Virginia University, PO Box 6125, Percival Hall, Morgantown, WV 26506. email: \\ jim.anderson@mail.wvu.edu, phone: (304) 293-3825, fax: (304) 293-2441
}

Written in the style of:

Transactions of the American Fisheries Society 


\section{ABSTRACT}

Few studies have analyzed the environmental variables that determine Centrarchidae (sunfish and bass) nest site selection and magnitude of response to perceived harm in rivers with multiple sympatric species. The nesting behavior of male centrarchids - rock bass (Ambloplites rupestris), smallmouth bass (Micropterus dolomieu), redbreast sunfish (Lepomis auritus), and longear sunfish (Lepomis megalotis) - was recorded from visual surveys on the Cacapon River, West Virginia, USA during the summer of 2010. For each nest found, species and size were recorded, along with status (empty, eggs, or larvae) and a suite of environmental variables. These environmental variables were also measured at random sites for comparison. Nest reuse, nest success rate, and detection probability were determined through the visual surveys. The response of nest-guarding male centrarchids to perceived harm was measured experimentally using four response variables, with the observer acting as a novel threat to induce flight behavior. Nest site selection, nest success, and response of males to perceived harm were analyzed using a priori general linear models and Akaike's Information Criterion $\left(\mathrm{AIC}_{\mathrm{c}}\right)$ scores. All four species selected nest sites that were significantly different from random sites sampled within the river. Distance to nearest centrarchid nest, distance to nearest cover object, distance to shore, and water velocity were most important in distinguishing nests from random sites. Distance to cover object and water velocity had the greatest impact on nest success. Three of the four response variables produced strong (limited parameter) models. Male size, water depth, and distance to cover object influenced how close the observer could approach before inducing flight behavior, how long the male took to return to the nest, and how far the retreating male traveled from the nest to seek refuge. Nest reuse was observed in all species except smallmouth bass, and was most common in longear sunfish. Based on our results, the study species appear to experience high competition 
for nest sites due to similar selection pressures, with smallmouth bass likely experiencing the greatest negative effect. Distance to cover object was the only variable that was present in nest selection, nest success, and threat response models. Therefore, nesting behavior in these species (including flight response and nest selection) is largely dictated by the presence and proximity of in-stream cover. If in-stream cover is lost due to anthropogenic effects, males may devote less time guarding their nests against brood predators, which in turn may reduce recruitment.

\section{INTRODUCTION}

The males of all centrarchid species (family Centrarchidae, sunfish and bass) construct circular nest-depressions in sediment by vigorous fanning of the caudal fin. Each nest takes a male about 2 days to complete (Jennings 1991). The nest depression is cleared of large and fine sediments, pieces of vegetation, and other materials by mouth and by fin undulation. The nests are kept clear throughout the spawning bout (Breder 1936; Thorp 1988).

Male centrarchids select nest sites based on a range of environmental variables that vary with species, habitat type, time of year, and male size. Longear sunfish (Lepomis megalotis) select nest sites based on depth, water velocity, and substrate composition (Bietz 1981), proximity to in-stream cover objects (Mueller 1980), and proximity to other sunfish nests (Jennings 1991; Jennings and Philipp 1992). Redbreast sunfish (Lepomis auritus) nest in areas of shallow depth, low water velocity, and close proximity to upstream cover objects (Breder 1936; Helfrich et al. 1991). In lentic systems, rock bass (Ambloplites rupestris) select sites near other rock bass nests (Gross and Nowell 1980), whereas rock bass in lotic systems select sites downstream of cover objects (Noltie and Keenleyside 1987). Smallmouth bass (Micropterus dolomieu) also nest in areas of low velocity, and often beneath overhead cover (Winemiller and Taylor 1982). 
Coloniality is common in a number of centrarchid species. Colonial nests are far less likely to be invaded by brood predators, such as snails and Ameiurus catfish than are solitary nests (Gross and MacMillan 1981). Peripheral nests are also less likely to be depredated than centrally-located nests. This finding has been linked to cumulative defense, where multiple members of a colony will mob approaching predators, and the reduced time any individual male must devote to deterring predators (Breder 1936; Gross and MacMillan 1981). Colonies often form around one or two larger males, with the majority of the colony composed of smaller individuals. These smaller males may practice cuckoldry, which occurs when the smaller males quickly fertilize freshly laid eggs in the nests of physically superior individuals; this behavior is common among centrarchids (Jennings and Philipp 1992; Neff 2003).

Centrarchid species have multiple spawning bouts within a season; individual males generally nest multiple times as well (Gross and Nowell 1980; Cote and Gross 1993; Danylchuk and Fox 1996; Cargnelli and Neff 2006). Multiple bouts protects against environmental fluctuations typical of many freshwater systems. These environmental conditions range from fluctuating prey populations to intermittent flooding events (Winemiller and Taylor 1982; Noltie and Keenleyside 1987; Fox and Crivelli 1998). The period between spawning bouts is believed to correspond to the time necessary for an additional clutch of eggs to ripen within a female centrarchid. Young from the previous spawning bout always hatched and left the nest before the females of the species again developed mature eggs (Taylor 1978).

Centrarchids nesting after the first bout of a season may reuse other centrarchid nests, largely to preserve the energy required in nest construction (Breder 1936; Gross and Nowell 1980; Thorp 1988; Jennings 1991). Occasionally, an individual male may also exhibit nest-site fidelity and reuse the same nest during multiple bouts in a season (Breder 1936; Gross and 
Nowell 1980; Jennings 1991). Centrarchids are not the only fish species in which nest site reuse has been observed; it is relatively common in species which construct nests. Members of Salmonidae may preferentially superimpose their redds over preexisting redds created by other members of the species. This behavior removes the fertilized eggs of competing trout, and also reduces the amount of sediment that needs to be excavated (Essington et al. 1998).

Nest-guarding centrarchids are preyed upon by a number of aquatic and terrestrial predators. Continuation of nest- and egg-tending behavior in the presence of such predators decreases the probability of survival of the adult male, but in turn protects the nest from piscivores, brood predators, and brood parasites. Parental investment (time spent nest-guarding, etc.) during consistent threat of nest-predation will vary based on the value and needs of the current offspring (Cooke et al. 2008). Nest abandonment behavior in response to predation threat, therefore, should be balanced by perceived future reproductive fitness (Pressley 1981).

Several researchers have studied the response of centrarchids to the perceived threat of predation. When exposed to perceived threats, male centrarchids spend less time on their nests and less time tending to the nest (egg-fanning, etc.) while guarding them (Mueller 1980; Winkelman 1996). However, when driven from their nests, the males returned to their nests more quickly when eggs were present than when the nests were empty. This is likely because unguarded centrarchid eggs are quickly taken by brood predators (Colgan 1988). The presence of eggs has similar effects on other nest-guarding fish species, including the common goby (Pomatoschistus microps) and three-spine stickleback (Gasterosteus aculeatus) (Pressley 1981; Magnhagen and Vestergaard 1991).

Little research has been conducted on the differences in nest site selection and nest reuse in sympatric centrarchid species. Additionally, few studies have examined the influence of the 
environmental characteristics of nesting sites on flight behavior due to perceived harm in male centrarchids. In this study we measured nest site characteristics in four species to determine which characteristics differentiate nesting habitat use. Multiple aspects of flight behavior were also studied and linked to specific nest site characteristics to determine which affected the magnitude of the response.

\section{STUDY SITE}

The Cacapon River, West Virginia is a $3^{\text {rd }}$ order tributary of the Potomac River in the Ridge-and-Valley physiographic province (Ryder et al. 2009). The climate is humid continental, with hot summers and precipitation totaling about $91 \mathrm{~cm}$ annually (Gilles 2009).

Our study was conducted on a $8.5 \mathrm{~km}$ stretch of the Cacapon River, located between $39^{\circ} 05^{\prime} 33^{\prime \prime} \mathrm{N}, 78^{\circ} 35^{\prime} 12^{\prime \prime} \mathrm{W}$ and $39^{\circ} 07^{\prime} 53^{\prime \prime} \mathrm{N}, 78^{\circ} 32^{\prime} 35^{\prime \prime} \mathrm{W}$ in northern Hardy and southern Hampshire Counties, WV (Fig. 1). The stretch begins at a public put-in located just north of Wardensville, West Virginia, and ends at a private take-out point on Mr. Sandy White's property.

The stretch was composed of riffle- and pool-dominated sections in about equal proportions. Additionally, substrate composition was variable (e.g., many sections are almost $100 \%$ bedrock, whereas others are settling areas for silt and clay), resulting in a wide range of microhabitats. Only small sections of the stretch supported submerged aquatic vegetation; most had bare substrate.

Early in the summer of 2010 extensive rains greatly increased the river's discharge, destroying many centrarchid nests before they could be completed. Late in the summer, drought gradually decreased discharge and depth in the river. In some areas riffles became barriers to downstream or upstream movement of centrarchids. Nests that were built near the banks earlier 
in the summer were exposed, preventing them from being reused in later bouts. During 2009 and 2010, late-summer green algal blooms smothered other centrarchid nesting areas. Large woody debris increased greatly in abundance from 2009 to 2010, increasing the nesting habitat for species that preferentially nest near cover objects.

\section{METHODS}

\section{Centrarchid nesting site surveys}

The study site was surveyed for nesting centrarchids once every 2 to 7 days during 2009 and 2010. Surveys began in early April and continued into August, until no new nests were located (Breder 1936; Fox and Crivelli 1998). Observational and experimental techniques were developed and refined during 2009, then used during 2010.

From April to August 2010, all nests within the stretch were located from the bank or from a kayak by using polarized sunglasses to observe objects and fish activity underwater. Maps were created depicting the location of each nest and other objects useful for future location and identification (Appendix Ic). Any nests that were difficult to identify on later surveys, or solitary nests not given their own maps, were marked by placing flagging tape on the bank. Each nest located during each survey was numbered on the maps, its status was recorded (unoccupied or occupied; if occupied, the species was identified), and it was examined closely for the presence of eggs or fry. The size of the male guarding each nest was determined by comparing fish length to the size of underwater objects, and estimated to the nearest inch (later converted to $\mathrm{cm})$. This was used in part to differentiate individuals during future surveys.

The following habitat characteristics were measured for each new nest located: water depth, percent canopy cover, water velocity, distance to nearest cover object, distance to nearest 
neighboring centrarchid nest (occupied or unoccupied), distance to shore, distance to deepwater, and substrate composition. Water depth, taken with a meter stick to the nearest quarter $\mathrm{cm}$, was recorded as the distance from the surface of the water to the upstream rim of the nest. Water velocity was measured using a Marsh-McBirney Flo-Mate 2000® velocity meter (Hach Co., Loveland, Colorado) and a $90 \mathrm{~cm}$ wading rod. Two velocity readings (to the nearest $0.05 \mathrm{ft} / \mathrm{sec}$, converted to $\mathrm{m} / \mathrm{sec}$ ) were collected from the upstream and downstream rims of the nest $2 \mathrm{~cm}$ from the substrate, and averaged to obtain an average velocity over the nest itself (Helfrich et al. 1991). Percent canopy cover was measured using a Spherical Crown Concave Densiometer (Forestry Suppliers, Jackson, Mississippi), and rounded to the nearest 5\%. The distance from the rim of each nest to the nearest underwater cover object $<500 \mathrm{~cm}$ away (based on approximate underwater visual clarity) was measured with a tape measure to the nearest quarter $\mathrm{cm}$, and the type was recorded. We considered any object (woody debris, boulders, patches of aquatic vegetation, etc.) that could fully conceal the associated nest-guarded male. Distance to the nearest neighboring centrarchid nest $<300 \mathrm{~cm}$ away (the distance between the rims of the two nests that were closest to each other) was taken with a tape measure to the nearest quarter $\mathrm{cm}$. Distance between the nest's rim and the nearest shore was taken using a tape measure to the nearest quarter $\mathrm{cm}$. Distance to the nearest area of deep water ( $>1 \mathrm{~m}$ in depth) with negligible or low water velocity at $60 \%$ depth, was taken with a tape measure to the nearest $5 \mathrm{~m}$ (Helfrich et al. 1991). Substrate composition was estimated visually: the cover of each size class was estimated to the nearest $10 \%$ for both the interior of the nest, and for the un-nested substrate just upstream of the nest (to approximate substrate composition prior to nest construction); clay and silt $(0-0.1 \mathrm{~mm})$, sand (>0.1 $-2 \mathrm{~mm})$, gravel $(>2-76 \mathrm{~mm})$, and cobble (> $76 \mathrm{~mm})$. Clay and silt are estimated together due to a difficult in visually distinguishing these two classes; bedrock 
and boulders are combined with cobble because all three classes represent objects centrarchids are incapable of moving.

For every nest found, a randomly selected point within the river was sampled for the same characteristics mentioned above. Each random point was sampled from within the study stretch (not just within known nesting areas), and was selected using a map of the stretch. The data obtained from all random points were used to determine the available habitat' within the sampling stretch.

Distance measurements for nearest nest, nearest cover object, and nearest deepwater habitat were later converted to discrete distance classes. Limits were set so as to standardize as closely as possible the number of observations that fell into each class (Andren and Angelstam 1988; Diniz-Filho et al. 2003). The classes for distance to nest were: 0-26 cm (1), >26-45 cm (2), $>45-66 \mathrm{~cm} \mathrm{(3),} \mathrm{>66-100} \mathrm{cm} \mathrm{(4),} \mathrm{>100-300} \mathrm{cm} \mathrm{(5),} \mathrm{and} \mathrm{>300} \mathrm{cm} \mathrm{(6).} \mathrm{The} \mathrm{classes} \mathrm{for} \mathrm{distance} \mathrm{to}$ cover object were: 0-15 cm (1), >15-40 cm (2), >40-75 cm (3), >75-160 cm (4), >160-350 cm (5), and >350 cm (6). The classes for distance to deepwater were: $0 \mathrm{~m}$ (1), 5 or $10 \mathrm{~m} \mathrm{(2),} 15$ or 20 $\mathrm{m}(3), 25$ or $30 \mathrm{~m}(4), 35$ or $40 \mathrm{~m}(5)$, and $40+\mathrm{m}(6)$.

Each located nest was also marked as either colonial or non-colonial. A colonial nest was defined as one in which the male guarding it was involved in direct and frequent interaction with two or more other males guarding nests in the vicinity. The interacting males did not need to be of the same species, and the interaction did not need to involve contact (i.e., attention given to other males was considered).

Nests currently undergoing construction by a male were not sampled for habitat characteristics, but were marked and rechecked for completion at a later date. An incomplete nest was identified by witnessing the actual excavation process (caudal fanning while spinning, with 
snout at the center of the nest), or by detection of large particles of vegetation within the nest (which are actively removed from the nest before spawning begins). The presence of high proportions of silt or clay in the nest (which would normally be swept away by the male) usually indicated an abandoned nest (Taylor 1978).

During each survey, all previously located nests (as indicated by the maps created for the nests) were relocated, and their statuses were reevaluated. Each nest that, during the previous survey, was occupied by a centrarchid but was currently unoccupied was examined for possible explanations for abandonment. These included, but were not limited to, an abundance of gastropods, a fungal infection, an unhatched brood, or a completed spawning event.

\section{Centrarchid site selection analysis}

The differences between the environmental variables measured for each species and random sites were compared using global Kruskal-Wallis tests followed by Mann-Whitney tests for multiple comparisons. The $\alpha$-levels were Bonferroni corrected to 0.003 for 16 variable Kruskal-Wallis tests and 0.005 for 10 pair-wise Mann-Whitney tests (Merovich and Petty 2010). Differences in nest success between species and nesting habits, and between selection for cover objects, were compared using Chi-square tests with Yates' correction for continuity.

Nonmetric multidimensional scaling (NMDS) arranges more similar sites closer together in an ordination space (Wagner et al. 2000). The statistical program R (version 2.11.1) generated NMDS ordination plots of random and nest sites with two, three, and four dimensions using a Wisconsin double standardization (habitat variables are standardized by maxima, and species by variable totals) and Bray-Curtis distance matrices based on 11 habitat variables. The lowest dimension was used unless the stress (NMDS output indicating unexplained variation in the community composition) was significantly reduced by increasing the dimensionality. The 
differences between the random sites and centrarchid nest sites (and the differences between the nest sites of different species) were analyzed with a permutational multivariate analysis of variance (PERMANOVA) using distance matrices in the program $\mathrm{R}$ (function adonis) (Wildsmith et al. 2009).

A scatterplot matrix was created in the statistical program $\mathrm{R}$ with the variables measured to reveal collinearity. Two variables with high Pearson's Correlation coefficient $\left(\mathrm{r}^{2} \geq 0.75\right.$ or $\mathrm{r}^{2} \leq$ -0.75) were considered collinear. However, none of the variables measured were correlated in this way, and all were included in analysis.

General linear models were developed to predict nest site selection in all four species, and nest success (nests that received eggs from one or more females) in the two species (longear sunfish and rock bass) with large sample sizes for successful nests (Bacheler et al. 2010). Global models (containing all possible parameters) were tested for homoscedasticity, linearity, and error normality prior to analysis. Model selection was based on Chamberlin's multiple working hypothesis approach (Chamberlin 1931). Site selection and nest success were considered separately for each species using eight a priori models. These models were unique to each species and developed based on the literature or professional judgment. In instances where too few papers addressing key environmental variables were found for a specific species, papers based on centrarchid species with similar nesting habits were used instead.

Models were based on nesting date (DA), male size (MS), distance to nearest centrarchid nest (DN), distance to nearest cover object (DC), distance to shore (DS), distance to deepwater (DD), water depth (WD), water velocity (WV), canopy cover (CC), proportion of silt and clay around the nest (ST), proportion of sand around the nest (SD), proportion of gravel around the nest (GR), proportion of cobble around the nest (CO), proportion of silt and clay in the nest (SN), 
proportion of sand in the nest (AN), proportion of gravel in the nest (GN), and proportion of cobble in the nest $(\mathrm{CN})$. The following models were considered for longear sunfish nest site selection $($ nest $=1$, random site $=0)$ and nest success $($ successful $=1$, unsuccessful $=0$ ):

1. $\mathrm{Y}=\mathrm{DN}+\mathrm{MS}+\mathrm{DA}$, for nest success, replaced with $\mathrm{Y}=\mathrm{DN}$ for site selection, suggested by Dupuis and Keenleyside (1988);

2. $\mathrm{Y}=\mathrm{DN}+\mathrm{WD}+\mathrm{WV}$, suggested by Bietz (1981);

3. $\mathrm{Y}=\mathrm{DS}+\mathrm{GR}$, suggested by Breder (1936);

4. $\mathrm{Y}=\mathrm{DC}+\mathrm{DN}+\mathrm{WV}$;

5. $\mathrm{Y}=\mathrm{DN}+\mathrm{DS}+\mathrm{WD}+\mathrm{CC}$;

6. $\mathrm{Y}=\mathrm{DC}+\mathrm{WV}+\mathrm{ST}$;

7. $\mathrm{Y}=\mathrm{WD}+\mathrm{MS}+\mathrm{ST}$, for nest success, replaced with $\mathrm{Y}=\mathrm{WV}+\mathrm{ST}+\mathrm{CO}$ for site selection; and

8. $\mathrm{Y}=\mathrm{DS}+\mathrm{WD}+\mathrm{GN}$, for nest success, replaced with $\mathrm{Y}=\mathrm{DN}+\mathrm{CC}+\mathrm{GR}$ for site selection.

The following models were considered for rock bass nest site selection and nest success:

9. $\mathrm{Y}=\mathrm{DC}+\mathrm{WD}+\mathrm{WV}$, suggested by Noltie and Keenleyside (1986);

10. $\mathrm{Y}=\mathrm{DN}+\mathrm{WD}$, suggested by Gross and Nowell (1980);

11. $\mathrm{Y}=\mathrm{SD}$, suggested by Danylchuk and Fox (1996) for pumpkinseed sunfish;

12. $\mathrm{Y}=\mathrm{DC}+\mathrm{MS}+\mathrm{CO}$, for nest success, replaced with $\mathrm{Y}=\mathrm{DC}+\mathrm{CO}$ for nest selection;

13. $\mathrm{Y}=\mathrm{DD}+\mathrm{WD}+\mathrm{WV}$;

14. $\mathrm{Y}=\mathrm{DC}+\mathrm{DS}+\mathrm{DA}+\mathrm{SN}$, for nest success, replaced with $\mathrm{Y}=\mathrm{DC}+\mathrm{DS}+\mathrm{ST}$ for nest selection; 
15. $\mathrm{Y}=\mathrm{DC}+\mathrm{DA}+\mathrm{ST}$, for nest success, replaced with $\mathrm{Y}=\mathrm{WD}+\mathrm{CC}+\mathrm{ST}$ for site selection; and

16. $\mathrm{Y}=\mathrm{DN}+\mathrm{DS}+\mathrm{DD}$, for nest success, replaced with $\mathrm{Y}=\mathrm{WV}+\mathrm{SD}+\mathrm{GR}$ for nest selection.

The following models based on the literature were considered for redbreast sunfish nest site selection:

17. $\mathrm{Y}=\mathrm{DN}+\mathrm{DC}+\mathrm{WV}$, suggested by Breder (1936);

18. $Y=W D+W V+G R$, suggested by Helfrich et al. (1991);

19. $\mathrm{Y}=\mathrm{DC}+\mathrm{WD}$, suggested by Breder (1936) for pumpkinseed sunfish;

20. $\mathrm{Y}=\mathrm{CC}+\mathrm{WV}$;

21. $\mathrm{Y}=\mathrm{DC}+\mathrm{WD}+\mathrm{WV}$;

22. $\mathrm{Y}=\mathrm{DN}+\mathrm{WD}+\mathrm{ST}$;

23. $\mathrm{Y}=\mathrm{DD}+\mathrm{CC}+\mathrm{ST}$; and

24. $\mathrm{Y}=\mathrm{DS}+\mathrm{DD}+\mathrm{WV}$.

The following models based on the literature were considered for smallmouth bass nest site selection:

25. $\mathrm{Y}=\mathrm{DC}+\mathrm{WD}+\mathrm{CC}$, suggested by Winemiller and Taylor (1982);

26. $\mathrm{Y}=\mathrm{DS}+\mathrm{WV}$, suggested by Lukas and Orth (1995);

27. $\mathrm{Y}=\mathrm{DC}+\mathrm{WV}$, suggested by Dauwalter and Fisher (2007);

28. $\mathrm{Y}=\mathrm{DD}+\mathrm{CC}+\mathrm{CO}$;

29. $\mathrm{Y}=\mathrm{DC}+\mathrm{DS}$;

30. $\mathrm{Y}=\mathrm{WV}$;

31. $\mathrm{Y}=\mathrm{DS}+\mathrm{WD}+\mathrm{CO}$; and 


\section{2. $\mathrm{Y}=\mathrm{DC}+\mathrm{WV}+\mathrm{ST}$.}

Model strength was measured using Akaike's Information Criterion corrected for small sample sizes $\left(\mathrm{AIC}_{\mathrm{c}}\right)$; the lowest $\mathrm{AIC}_{\mathrm{c}}$ value indicated the model with the least information lost (Burnham and Anderson 2002). Values were calculated and compared using the glm procedure in the statistical program R using the link function "Binomial".

The $\operatorname{AIC}_{\mathrm{c}}$ differences $\left(\Delta_{\mathrm{i}}=\mathrm{AIC}_{\mathrm{c}}\right.$ lowest - $\left.\mathrm{AIC}_{\mathrm{ci}}\right)$ and Akaike weights $\left(\mathrm{w}_{\mathrm{i}}\right)$ were calculated for each model considered for each species; $\mathrm{AIC}_{\mathrm{c}}$ differences indicated the strength of one model in comparison to the best model, whereas Akaike weights indicated the probability that the associated model was the best approximating model being considered. Models with $\Delta_{\mathrm{i}}<2$ have substantial support as the best approximating models. Therefore, all models with $\Delta_{\mathrm{i}}<2$ were averaged to generate a final approximating model (Burnham and Anderson 2002). Specifically, each model's variable estimates were multiplied by that model's comparative weight (e.g., if two models had $\mathrm{w}_{\mathrm{i}}=0.4$ and 0.2 , all associated variable estimates were multiplied by 0.67 and 0.33 respectively) and then summed for each variable.

\section{Centrarchid nest reuse}

The tendency for each centrarchid species to reuse nest sites (where a male centrarchid guards a nest that was built and guarded by a different male earlier in the season) was determined by comparing the number of reused nests per species to the total number of new nests, built during the same spawning bout by that species, within the study stretch. During the first spawning bout, a nest was only considered reused if the individual male guarding it was observed to have changed. During each subsequent bout, a male guarding a nest that was located during any previous bout was considered to be reusing the nest. A successful nest was defined as a male-guarded nest which received eggs from a female centrarchid. If the nest was abandoned 
or destroyed before receiving eggs, it was not successful. Overall nest success was defined as the proportion of nests (either across or within species) that received eggs before abandonment.

\section{Centrarchid response to perceived harm}

Each survey, the flight behavior in response to perceived harm of newly nesting centrarchids located within the stretch was studied. Only nests constructed within the previous week were considered. These surveys were conducted between the hours of 0900 and 1500 to minimize the effect of shadows on behavior, although exact time of day has negligible effect on male behavior (Colgan 1988). Each fish was approached by walking toward the nest, parallel to the shore in an upstream direction to maintain visibility. When the individual abandoned the nest to seek refuge, the approach was halted until the fish returned to the nest. The time of abandonment was recorded with a stop watch. Two times were taken: one for the time required for the individual to return within $1 \mathrm{~m}$ of the nest, and one for the time for the male's body to cross the rim of the nest. The time to return within a meter was considered because of a tendency for males to approach, but not fully return to, their nests. Presumably this approach allowed a male to assess whether there was a continuing threat to itself or its nest and weigh the costs of a full return.

Distance to refuge and refuge type (pool, sunken log, etc.) were also estimated visually. After the refuge and return time measurements were recorded, the distance from the nest to the approach point that induced a flight response was measured with a meter stick.

General linear models were developed predicting the magnitude of behavioral response of male longear sunfish to perceived harm (Bacheler et al. 2010). Each behavioral response variable was considered separately using 10 a priori models based on professional judgment. 
These models were identical for all four response variables. The models considered are as follows:

1. $\mathrm{Y}=\mathrm{DC}+\mathrm{DD}+\mathrm{MS}$;

2. $\mathrm{Y}=\mathrm{DD}+\mathrm{WD}+\mathrm{CC}$;

3. $\mathrm{Y}=\mathrm{DC}+\mathrm{WD}+\mathrm{CC}$;

4. $\mathrm{Y}=\mathrm{DN}+\mathrm{DC}+\mathrm{MS}$;

5. $\mathrm{Y}=\mathrm{DD}+\mathrm{MS}+\mathrm{WV}$;

6. $\mathrm{Y}=\mathrm{DN}+\mathrm{WD}+\mathrm{WV}$

7. $\mathrm{Y}=\mathrm{DC}+\mathrm{MS}+\mathrm{WV}$;

8. $\mathrm{Y}=\mathrm{DD}+\mathrm{CC}+\mathrm{GR}$

9. $\mathrm{Y}=\mathrm{DS}+\mathrm{WD}+\mathrm{MS}$; and

10. $\mathrm{Y}=\mathrm{DN}+\mathrm{WV}+\mathrm{GN}$.

Akaike's Information Criterion, corrected for small sample sizes $\left(\mathrm{AIC}_{\mathrm{c}}\right), \mathrm{AIC}_{\mathrm{c}}$ differences $\left(\Delta_{\mathrm{i}}\right)$, and Akaike weights $\left(\mathrm{w}_{\mathrm{i}}\right)$ were calculated for each candidate model (Burnham and Anderson 2002) in program R using the GLM procedure (link function = Gaussian).

Occupancy estimations were calculated for each nesting area. Nests were surveyed during June and July 2010, and the Geissler-Fuller method was used to determine probability of detection of nesting centrarchids (Mackenzie et al. 2006). Specifically, 30 nests were surveyed, with five individual approaches per nest. Each approach was separated by at least 10 minutes to allow the fish to return to their normal nesting behavior. A longer time span was not required, as centrarchids return to normal nesting behavior quickly following disturbances (Colgan 1988). 


\section{RESULTS}

\section{Centrarchid nest site surveys}

Four species of centrarchids were found nesting in the Cacapon River: rock bass (Ambloplites rupestris), smallmouth bass (Micropterus dolomieu), redbreast sunfish (Lepomis auritus), and longear sunfish (Lepomis megalotis). Rock bass ( $n=31$ nests) and smallmouth bass ( $n=8$ nests) began nesting earlier in the season than other centrarchids; the first nests for both species were located on May 16. Redbreast sunfish ( $n=27$ nests) began nesting on May 27, at a water temperature of $21.2{ }^{\circ} \mathrm{C}$. Longear sunfish ( $n=97$ nests) began nesting on June 3, at a water temperature of $22.7^{\circ} \mathrm{C}$ (J. L. Pitchford, unpublished data). The last nesting smallmouth bass were located on June 16, and the last redbreast sunfish were located on June 20. The majority of rock bass completed nesting by June 16; however, three individuals were observed nesting at the end of July. Longear sunfish nested fairly consistently until July 28, when the last nesting individuals were located (Appendix IIc).

Nesting male smallmouth bass were longer than all other species (Table 1). The frequency of nest reuse was highest in longear sunfish (11.3\%), followed by rock bass (10.0\%), redbreast sunfish (7.4\%), and was not observed in smallmouth bass. Reused nest success (37.5\%, $n=16)$ and newly constructed nest success $(31.3 \%, n=147)$ were not significantly different from one another $\left(\chi_{1}^{2}=0.61, P=0.82\right)$.

Smallmouth bass had the highest (50\%) and redbreast sunfish had the lowest (4\%) nest success. Nest success was $45 \%$ in rock bass and $34 \%$ in longear sunfish. Nest success was not significantly different between longear sunfish and rock bass $\left(\chi_{1}^{2}=0.82, P=0.37\right)$, longear sunfish and smallmouth bass $\left(\chi_{1}^{2}=0.28, \mathrm{p}=0.60\right)$, or rock bass and smallmouth bass $\left(\chi_{1}^{2}=0.02\right.$, $P=0.88)$. Nest success was significantly lower $(P<0.01)$ in redbreast sunfish than in longear sunfish $\left(\chi_{1}^{2}=8.29\right)$, rock bass $\left(\chi_{1}^{2}=10.86\right)$, and smallmouth bass $\left(\chi_{1}^{2}=7.35\right)$. 
Nesting depth was greatest in smallmouth bass, and least in longear sunfish (Table 1). All species nested at depths numerically lower than the average depth at the random sites. Average distance to shore was also greatest in smallmouth bass, and least in longear sunfish. Distance from shore for random sites was significantly greater $(P<0.05)$ than all species except smallmouth bass.

Among longear sunfish nests, $87.6 \%$ were located within $300 \mathrm{~cm}$ of another centrarchid nest. This proportion was $16.1 \%$ in rock bass, $25.9 \%$ in redbreast sunfish, $12.5 \%$ in smallmouth bass, and $6.12 \%$ among random sites. Of the longear nests located near another nest, $73.2 \%$ were closest to another longear sunfish nest. Unoccupied nests comprised $14.4 \%$ of the proximate nests; no longear nests were located in proximity to the nests of another centrarchid species. By contrast, no rock bass or smallmouth bass nests were located in proximity to a nest guarded by a male of the same species. Distance to nearest neighboring nest was greatest in smallmouth bass, and least in longear sunfish (Table 1). Distance to nearest nest in random sites was numerically greater than that for all species. Coloniality was only observed in longear sunfish; $42.3 \%$ of longear sunfish nests were colonial. Colonial longear sunfish nest success $(34.1 \%, n=41)$ was similar to solitary-nesting nest success $(33.9 \%, n=56)\left(\chi^{2}{ }_{1}=0.04, P=0.85\right)$.

Of rock bass nests, $45.2 \%$ were located within $500 \mathrm{~cm}$ of a cover object; this proportion was $66.7 \%$ in redbreast sunfish, $52.6 \%$ in longear sunfish, $87.5 \%$ in smallmouth bass, and $50 \%$ among random sites. The most common cover object across all species and random sites was large, submerged rocks (Fig. 2). All centrarchid species selected upstream rocks less than rocks located on any other side of the nest $\left(\chi^{2}{ }_{1}=9.14, P=0.003\right)$. Fully submerged logs were selected over partially submerged logs in all centrarchid species $\left(\chi_{1}^{2}=4.11, P=0.043\right)$; only longear sunfish nested near partially submerged logs. One redbreast sunfish nest was located near a 
discarded tire. Distance to nearest cover object was greatest in smallmouth bass, and least in longear sunfish (Table 1). Distance to nearest cover object among random sites was numerically greater than for all species.

Deepwater habitats were located near $71.0 \%$ of rock bass nests, $92.6 \%$ of redbreast sunfish nests, $78.4 \%$ of longear sunfish nests, $75.0 \%$ of smallmouth bass nests, and $68.4 \%$ of random sites. The average distance to deepwater was greatest in rock bass and least in longear sunfish (Table 1). Distance to deepwater among random sites was numerically lower than that for all species. Average canopy cover over centrarchid nests was greatest in smallmouth bass and least in redbreast sunfish, but was not significantly different among species.

Water velocity over nest sites was greatest in rock bass $(13.6 \mathrm{~cm} / \mathrm{sec}$ maximum) and least in longear sunfish $(9.8 \mathrm{~cm} / \mathrm{sec}$ maximum) (Table 1$)$. Water velocity at random sites was numerically higher than all species' nest sites except rock bass, and ranged from negligible (approximately $0.0 \mathrm{~cm} / \mathrm{sec}$ ) to $27.1 \mathrm{~cm} / \mathrm{sec}$.

Centrarchid nests were generally located in areas of the river with greater clay and silt substrate than random sites (Table 1). All three other sediment classes were found at lower proportions at nest sites than at random sites (Appendices IIIc-VIIc). Smallmouth bass nested in areas with the highest proportions of fine sediments (clay and silt), and smallmouth bass nests contained higher proportions of fine sediments than did the nests of the other species. Smallmouth bass nests also had the highest proportions of sand, but the lowest proportions of gravel and cobble/bedrock.

\section{Centrarchid nest site selection}

In nonmetric multidimensional scaling (NMDS) ordination space, longear sunfish nest sites clustered separately from random sites based on silt and clay proportions and distance to 
other centrarchid nests (Appendix VIIIc). Rock bass nest sites largely overlapped with random sites (Appendix IXc). Redbreast sunfish nest sites overlapped with random sites, but proportions of gravel and water velocity separated random sites from nest sites (Appendix Xc). Smallmouth bass nest sites overlapped with random sites; however, conclusions were difficult given the small sample size of smallmouth bass (Appendix XIc). Considered together, all species separated from random sites in ordination space (Fig. 3).

In NMDS ordination space, longear sunfish separated from rock bass nest sites based on nest depth, sand proportion, and distance to shore (Appendix XIIc); and from redbreast sunfish based on distance to nest and cover object, and canopy cover (Appendix XIIIc). Longear sunfish nest sites had higher gravel proportions than smallmouth bass nest sites (Appendix XIVc). Rock bass clustered separately from redbreast sunfish based on velocity and sand proportion (Appendix XVc), and from smallmouth bass based on velocity and distance to cover object (Appendix XVIc). Smallmouth bass nested farther from cover objects than did redbreast sunfish (Appendix XVIIc).

All centrarchid species nested in habitat significantly different from the random sites based on PERMANOVA: longear sunfish $\left(\mathrm{F}_{1,192}=87.56, P=0.001\right)$, rock bass $\left(\mathrm{F}_{1,126}=8.09, P\right.$ $=0.002)$, redbreast sunfish $\left(\mathrm{F}_{1,122}=8.51, P=0.001\right)$, and smallmouth bass $\left(\mathrm{F}_{1,103}=5.32, P=\right.$ 0.006). Longear sunfish nest sites were significantly different from the nest sites of the other three species based on the 12 habitat characteristics: rock bass $\left(\mathrm{F}_{1,126}=21.48, P=0.001\right)$, redbreast sunfish $\left(\mathrm{F}_{1,122}=18.45, P=0.001\right)$, and smallmouth bass $\left(\mathrm{F}_{1,103}=11.12, P=0.001\right)$. The other species (rock bass, redbreast sunfish, and smallmouth bass) nested in habitat that was not significantly distinct (all $\mathrm{F}<2.5$ and $P>0.1$ ). 
The differences between longear sunfish nests and random sites were best approximated using distance to shore, distance to nest, water depth, and canopy cover as parameters (Table 2). Successful nests were best predicted in longear sunfish using distance to cover, distance to nest, water velocity, silt and clay surrounding the nest, and gravel surrounding the nest as parameters (Table 3). The final model was based on three models with substantial support $\left(\Delta_{\mathrm{i}}<2\right)$, and is as follows:

$$
\mathrm{Y}=-1.963+0.235(\mathrm{DC})+0.018(\mathrm{DN})-0.006(\mathrm{WV})-0.001(\mathrm{ST})-0.005(\mathrm{GR})
$$

The differences between rock bass nests and random sites were best approximated using distance to shore, distance to cover, and silt and clay surrounding the nest as parameters (Table 2). Successful nests were best predicted in rock bass using distance to cover, water depth, water velocity, distance to neighboring nest, and distance to deepwater as parameters (Table 3). The final model was based on three models with substantial support $\left(\Delta_{\mathrm{i}}<2\right)$, and is as follows:

$$
\mathrm{Y}=4.968+0.082(\mathrm{DC})-0.101(\mathrm{WD})-0.178(\mathrm{WV})+0.042(\mathrm{DN})+0.120(\mathrm{DD})
$$

The differences between redbreast sunfish nests and random sites were best approximated using distance to cover, distance to nest, and water velocity as parameters (Table 2). The differences between smallmouth bass nests and random sites were best approximated using distance to cover, distance to shore, and water velocity as parameters (Table 2). The final model was based on two models with substantial support $\left(\Delta_{i}<2\right)$, and is as follows:

$$
\mathrm{Y}=1.104-0.845(\mathrm{DC})-0.001(\mathrm{DS})-0.059(\mathrm{WV})
$$

\section{Centrarchid response to perceived harm}

Flight behavior in response to perceived harm was observed in 58 nesting male longear sunfish. Males temporarily abandoned their nests when the observer was $267.2 \pm 11.5 \mathrm{~cm}$ from the nest $(112.0 \mathrm{~cm}$ minimum). Males took $21.0 \pm 2.6 \mathrm{sec}$ to return to within $1 \mathrm{~m}$ of their nests $(3$ 
sec minimum, $105 \mathrm{sec}$ maximum) and $26.9 \pm 3.0 \mathrm{sec}$ to return to nest guarding. The survey time was therefore an average of $5.93 \pm 1.46 \mathrm{sec}$. Refuges were $7.5 \pm 0.8 \mathrm{~m}$ from the nests. Refuge types included deepwater (36.2\% of refuges), shoreline (very shallow water near shore; $20.1 \%$ ), large submerged rocks (12.1\%), submerged logs (10.3\%), and SAV (8.6\%).

Observer distance necessary to induce flight behavior was best approximated using distance to shore, water depth, and male size as parameters (Table 4). Refuge distance was best approximated using distance to cover, male size, and water velocity as parameters (Table 4).

The time to return to within $1 \mathrm{~m}$ of the nest was best approximated using distance to cover, distance to deepwater, male size, canopy cover, and gravel surrounding the nest as parameters (Table 4). The final model was based on two models with substantial support $\left(\Delta_{\mathrm{i}}<2\right)$, and is as follows:

$$
\mathrm{Y}=-23.64+1.781(\mathrm{DC})+4.086(\mathrm{DD})+1.546(\mathrm{MS})-0.028(\mathrm{CC})+0.227(\mathrm{GR})
$$

The time to return to nest guarding was best approximated using distance to cover, distance to nest, distance to deepwater, male size, water depth, water velocity, canopy cover, gravel surrounding the nest, and gravel in the nest as parameters (Table 4). The final model was based on five models with substantial support $\left(\Delta_{\mathrm{i}}<2\right)$, and is as follows:

$$
\begin{gathered}
\mathrm{Y}=6.539+0.510(\mathrm{DC})+3.236(\mathrm{DN})+1.801(\mathrm{DD})+0.269(\mathrm{MS})-0.106(\mathrm{WD})+1.251(\mathrm{WV})- \\
0.058(\mathrm{CC})+0.100(\mathrm{GR})-0.005(\mathrm{GN})
\end{gathered}
$$

Using the program MARK (version 5.0), detection probability was estimated to be 0.747 \pm 0.036 . Of the 30 nests surveyed, 12 had males guarding them on all five of the observations, and $80 \%(n=24)$ of occupied nests were classified as such during the first visit (Appendix XVIIIc). 


\section{DISCUSSION}

\section{Centrarchid species nest site selection}

All four sympatric centrarchid species found nesting in the Cacapon River exhibited selection for specific nest sites. The environmental characteristics favored by each species were variable, likely as a means to reduce interspecific competition. Centrarchids partition nest sites both temporally and spatially (Breder 1936). Redbreast sunfish, rock bass, and smallmouth bass in the Cacapon River nested early in the season, avoiding potential competition with the locally common and later-nesting longear sunfish. The early-nesting species were more adapted to do so given their comparatively large size, which increased energy reserves following winter torpor (Ridgway et al. 1991; Danylchuk and Fox 1996).

Longear sunfish in the Cacapon River nested in habitat more distinct from random sites than the other three species, suggesting a greater degree of nest site specialization. Likewise, longear sunfish nested in habitat distinct from the other three species, based largely on water velocity and distance to cover objects and other centrarchid nests. Although selection for close proximity to other nests was observed in this species, and indeed longear sunfish were the only colony-nesting species, there was no reproductive advantage to colony-nesting in the Cacapon River. Similar results have been reported in previous studies (Bietz 1981; Jennings and Philipp 1992).

Redbreast sunfish and smallmouth bass nested in close proximity to cover objects. Similar habits in these species, and specifically the use of cover objects to reduce energy expenditure when maintaining a position over a nest in flowing water, have been reported previously (Breder 1936; Winemiller and Taylor 1982; Helfrich et al. 1991; Dauwalter and Fisher 2007). However, energy preservation may not be a driving factor in nest site selection 
across centrarchid species in our study. Several redbreast sunfish and smallmouth bass nested in areas of high water velocity, and therefore relied on in-stream cover, even when suitable nesting areas with negligible velocity were located nearby. Rock bass nest sites experienced water velocity approximately equal to that of random sites, and individual males were more likely to receive eggs when they nested far from cover objects. This contradicts previous findings that rock bass prefer nesting behind cover objects that reduce water velocity (Noltie and Keenleyside 1986, 1987), and therefore in our study this species was not selecting sites that minimized energy expenditure.

\section{Factors driving site selection}

Additionally, the reuse of nest sites can lessen the energy demands of nest construction. However, few centrarchids in the Cacapon River reused nest sites, and individuals reusing nest sites were not more successful than individuals constructing new nests. Nest reuse was most common in rock bass directly following the spawning bouts of other species, taking advantage of favorable sites (rather than pre-constructed nests) as competition decreased. Most longear sunfish reused nests within colonies that were occupied during multiple spawning bouts, again driven by selection for favorable sites. Similar reuse has been observed in bluegill (Lepomis macrochirus) (Bartlett et al. 2010). During the summer of 2010, prolonged drought lead to a steady decrease in overall river depth. Many nest sites from early in the season rose above water level by midsummer, while others were unusable due to algal growth. This was likely partially responsible for the drop-off in nest reuse from what was observed during 2009.

If energy expenditure was not driving competition for nest sites, it is probable that female choice or protection from predators was responsible for the findings of this study. Longear sunfish nest site selection and nest success have previously been attributed to female choice 
(Dupuis and Keenleyside 1988; Jennings and Philipp 1992), which drives solitary-nesting. Solitary nesters are also less likely to suffer brood predation by conspecifics, despite higher brood predation from gastropods and Ameiurus catfish (Gross and MacMillan 1981). Colonies generally form around one or two larger males, with the majority of the colony composed of physically inferior individuals seeking protection from predators (Gross and MacMillan 1981) and more reproductive opportunities from females attracted by larger males (Gross and Nowell 1980; Jennings and Philipp 1992).

\section{Response to perceived harm}

Male centrarchids in the Cacapon River also likely selected nest sites based on protection from piscivorous predators. Environmental variables that protect against predation attempts leave more time and energy for nest-tending and guarding (Coleman and Fischer 1991; Winkelman 1996; Cooke et al. 2008). Despite the reduction in success probability associated with close proximity to cover objects, the magnitude of response to perceived harm was greater for males nesting far from cover objects and in deeper water in the Cacapon River. Predatory wading birds, such as herons, select shallow over deep water to hunt due to the increased vulnerability of prey in shallow water (Lantz et al. 2010). Large herons are generally ineffective hunters in water over $30 \mathrm{~cm}$ (Dimalexis and Pyrovetsi 1997). Therefore, increased boldness in deeper water would be expected if the observer in this study was perceived as a similar threat.

Individual size also had a substantial effect on response to perceived harm in Cacapon River centrarchids. In our study, larger males allowed the observer to approach closer to the nests before abandoning them, and sought refuge closer to their nests. Similarly, Golub et al. (2005) found that larger males exhibit a weaker response (specifically, they continue foraging behavior longer) when exposed to chemical alarm cues. However, smaller males returned to their 
nests more quickly in the Cacapon River than did larger males, perhaps because smaller males are less likely to attract females (Dupuis and Keenleyside 1988) and therefore placed added importance on guarding and cleaning or fanning their nests. Smaller males were also more likely to be supplanted on their nests by larger males (S. M. Selego, personal observation).

Nest status (empty, eggs, or larvae) had no effect on the magnitude of response, further suggesting the relative unimportance of energy expenditure on nesting behavior in Cacapon River centrarchids. Previous studies have suggested that the presence or absence of eggs or larvae is the most important factor affecting the boldness or aggressiveness of nest-guarding fishes (Pressley 1981; Magnhagen and Vestergaard 1991; Winkelman 1996). Males are expected to follow "Williams' principle", which predicts nest-guarding males will behave to maximize future reproductive potential (Sargent and Gross 1993). Therefore, if the threat posed to the male by the observer is perceived to outweigh the value of the nest (with or without eggs present), then the male will not continue nest-guarding (Wiegmann and Baylis 1995). Also, although human-induced flight behavior can be used to approximate centrarchid response to threat of predation, it may be more related to centrarchid response to recreational activity (fishing, boating, etc.) on a river. Therefore, given the commonality of such traffic on the Cacapon River, nest site selection may reflect an effort to reduce encounters with humans.

Several other site selection tendencies related to reduced threat response were observed in nesting centrarchids, but were not captured in the variables measured. Nests were never placed in areas where foam caused by riffle turbulence was present on the surface (S. M. Selego, personal observation). The presence of point bars and partially submerged logs also appeared to deter nest construction, presumably because they both obscured escape routes and provided perching points for piscivorous wading birds. 


\section{Conclusions}

Although habitat selection is driven by a complex set of interactions related to competition, it appears that competition for nest sites among male centrarchids in the Cacapon River is largely driven by female choice, conspecific brood predation, and the threat of large predators. Variation in nest site characteristics between species is likely intended to reduce overall competition for sites, and variation within a species likely represents a trade-off between natural and sexual selection.

\section{ACKNOWLEDGMENTS}

Funding and logistical support provided by National Fish and Wildlife Foundation, The Chesapeake Bay Trust, National Oceanic and Atmospheric Administration, FishAmerica Foundation, Canaan Valley Institute, and the Cacapon and Lost Rivers Land Trust. Thank you to the local landowners (especially Mr. Sandy White) for making this project possible. Finally, thank you to Charneé Lee Rose and Jonathon Pitchford for field assistance. This is scientific article xxxx of the West Virginia University Agricultural and Forestry Experiment Station.

\section{LITERATURE CITED}

Andren, H., and P. Angelstam. 1988. Elevated predation rates as an edge effect in habitat islands: experimental evidence. Ecology 69:544-547.

Bacheler, N. M., J. E. Hightower, S. M. Burdick, L. M. Paramore, J. A. Buckel, and K. H. Pollock. 2010. Using generalized linear models to estimate selectivity from short-term 
recoveries of tagged red drum Sciaenops ocellatus: effects of gear, fate, and regulation period. Fisheries Research 102:266-275.

Bartlett, J. A., M. P. Ward, S. J. Landsman, and J. M. Epifanio. 2010. Nest-site fidelity in parental male bluegill Lepomis macrochirus: spatial patterns and the influence of prior mating success. Journal of Fish Biology 77:890-906.

Bietz, B. F. 1981. Habitat availability, social attraction and nest distribution patterns in longear sunfish (Lepomis megalotis peltastes). Environmental Biology of Fishes 6:193-200.

Breder, C. M. 1936. The reproductive habits of the North American sunfishes (family Centrarchidae). Zoologica 21:1-48.

Burnham, K. P., and D. R. Anderson. 2002. Model selection and multimodel inference: a practical information-theoretical approach. Springer, New York.

Cargnelli, L. M., and B. D. Neff. 2006. Condition-dependent nesting in bluegill sunfish Lepomis macrochirus. Journal of Animal Ecology 75:627-633.

Chamberlin, T. C. 1931. The method of multiple working hypotheses. Journal of Geology 39:155-165.

Coleman, R. M., and R. U. Fischer. 1991. Brood size, male fanning effort and the energetics of a nonshareable parental investment in bluegill sunfish, Lepomis macrochirus (Teleostei: Centrarchidae). Ethology 87:177-188.

Colgan, P. W. 1988. Dynamics of nest defense by male centrarchid fish. Behavioural Processes $17: 17-26$.

Cooke, S. J., P. J. Weatherhead, D. H. Wahl, D. P. Philipp. 2008. Parental care in response to natural variation in nest predation pressure in six sunfish (Centrarchidae: Teleostei) species. Ecology of Freshwater Fish 17:628-638. 
Cote, I. M., and M. R. Gross. 1993. Reduced disease in offspring: a benefit of coloniality in sunfish. Behavioral Ecology and Sociobiology 33:269-274.

Danylchuk, A. J., and M. G. Fox. 1996. Size- and age-related variation in the seasonal timing of nesting activity, nest characteristics, and female choice of parental male pumpkinseed sunfish (Lepomis gibbosus). Canadian Journal of Zoology 74:1834-1840.

Dauwalter, D. C., and W. L. Fisher. 2007. Spawning chronology, nest site selection, and nest success of smallmouth bass during benign streamflow conditions. American Midland Naturalist 158:60-78.

Dimalexis, A., and M. Pyrovetsi. 1997. Effect of water level fluctuations on wading bird foraging habitat use at an irrigation reservoir, Lake Kerkini, Greece. Colonial Waterbirds 20:244-252.

Diniz-Filho, J. A. F, L. M. Bini, and B. A. Hawkins. 2003. Spatial autocorrelation and red herrings in geographical ecology. Global Ecology and Biogeography 12:53-64.

Dupuis, H. M. C., and M. H. A. Keenleyside. 1988. Reproductive success of nesting male longear sunfish (Lepomis megalotis peltases). Behavioral Ecology and Sociobiology 23:109-116.

Essington, T. E., P. W. Sorensen, and D. G. Paron. 1998. High rate of redd superimposition by brook trout (Salvelinus fontinalis) and brown trout (Salmo trutta) in a Minnesota stream cannot be explained by habitat availability alone. Canadian Journal of Fisheries and Aquatic Sciences 55:2310-2316.

Fox, M. G., and A. J. Crivelli. 1998. Body size and reproductive allocation in a multiple spawning centrarchid. Canadian Journal of Fisheries and Aquatic Sciences 55:737-748. 
Gilles, N. 2009. Cacapon Institute, High View, West Virginia (available from http://www.cacaponinstitute.org) accessed 21 March 2009.

Golub, J. L., V. Vermette, and G. E. Brown. 2005. Response to conspecific and heterospecific alarm cues by pumpkinseed in simple and complex habitats: field verification of an ontogenetic shift. Journal of Fish Biology 66:1073-1081.

Gross, M. R., and A. M. MacMillan. 1981. Predation and the evolution of colonial nesting in bluegill sunfish (Lepomis macrochirus). Behavioral Ecology and Sociobiology 8:163174.

Gross, M. R., and W. A. Nowell. 1980. The reproductive biology of rock bass, Ambloplites rupestris (Centrarchidae), in Lake Opinicon, Ontario. Copeia 1980:482-494.

Helfrich, L. A., K. W. Nutt, and D. L. Weigmann. 1991. Habitat selection by spawning redbreast sunfish in Virginia streams. Rivers 2:138-147.

Jennings, M. J. 1991. Sexual selection, reproductive strategies, and genetic variation in longear sunfish (Lepomis megalotis). Thesis, University of Illinois, Urbana-Champaign, Illinois.

Jennings, M. J., and D. P. Philipp. 1992. Female choice and male competition in longear sunfish. Behavioral Ecology 3:84-94.

Lantz, S. M., D. E. Gawlik, and K. I. Cook. 2010. The effects of water depth and submerged aquatic vegetation on the selection of foraging success of wading birds. Condor 112:460469.

Lukas, J. A., and D. J. Orth. 1995. Factors affecting nesting success of smallmouth bass in a regulated Virginia stream. Transactions of the American Fisheries Society 124:726-735. 
Mackenzie, D. I., J. D. Nichols, J. A. Royle, K. H. Pollock, L. L. Bailey, and J. E. Hines. 2006. Occupancy estimation and modeling. Elsevier Academic Press, Burlington, Massachusetts.

Magnhagen, C., and K. Vestergaard. 1991. Risk taking in relation to reproductive investments and future reproductive opportunities: field experiments on nest-guarding common gobies, Pomatoschistus microps. Behavioral Ecology 2:351-359.

Merovich, G. T., and J. T. Petty. 2010. Continuous response of benthic macroinvertebrate assemblages to a discrete disturbance gradient: consequences for diagnosing stressors. Journal of the North American Benthological Society 29:1241-1257.

Mueller, G. 1980. Effects of recreational river traffic on nest defense by longear sunfish. Transactions of the American Fisheries Society 109:248-251.

Neff, B. D. 2003. Paternity and condition affect cannibalistic behavior in nest-tending bluegill sunfish. Behavioral Ecology and Sociobiology 54:377-384.

Noltie, D. B., and M. H. A. Keenleyside. 1986. Correlates of reproductive success in streamdwelling male rock bass, Ambloplites rupestris (Centrarchidae). Environmental Biology of Fishes 17:61-70.

Noltie, D. B., and M. H. A. Keenleyside. 1987. Breeding ecology, nest characteristics, and nestsite selection of stream- and lake-dwelling rock bass, Ambloplites rupestris (Rafinesque). Canadian Journal of Zoology 65:379-390.

Pressley, P. H. 1981. Parental effort and the evolution of nest-guarding tactics in the threespine stickleback, Gasterosteus aculeatus. L. Evolution 35:282-295. 
Ridgway, M. S., B. J. Shuter, and E. E. Post. 1991. The relative influence of body size and territorial behavior on nesting asynchrony in male smallmouth bass, Micropterus dolomieu (Pisces: Centrarchidae). Journal of Animal Ecology 60:665-681.

Ryder, R. T., R. D. Crangle, M. H. Trippi, C. S. Swezey, E. E. Lentz, E. L. Rowan, and R. S. Hope. 2009. Geologic cross section D-D' through the Appalachian Basin from the Findlay Arch, Sandusky County, Ohio, to the Valley and Ridge Province, Hardy County, West Virginia. United States Geologic Survey, Reston, Virginia.

Sargent, R. C., and M. R. Gross. 1993. Williams' principle: and explanation of parental care in teleost fishes, p. 333-361. In: Behavior of teleost fishes. 2d ed. T. Pitcher (ed.). ChapmanHall, New York.

Taylor, J. N. 1978. Behavioral components of reproductive success in male sunfishes of the genus Lepomis. Dissertation, The University of Michigan, Ann Arbor, Michigan.

Thorp, J. H. 1988. Patches and the responses of lake benthos to sunfish nest-building. Oecologia 76:168-174.

Wagner, D. M., G. A. Feldhamer, J. A. Newman. 2000. Microhabitat selection by golden mice (Ochrotomys nuttalli) at arboreal nest sites. American Midland Naturalist 144:220-225.

Wiegmann, D. D., and J. R. Baylis. 1995. Male body size and paternal behavior in smallmouth bass, Micropterus dolomieu (Pisces: Centrarchidae). Animal Behavior 50:1543-1555.

Winemiller, K. O., and D. H. Taylor. 1982. Smallmouth bass nesting behavior and nest site selection in a small Ohio stream. Ohio Journal of Science 82:266-273.

Winkelman, D. L. 1996. Reproduction under predatory threat: trade-offs between nest guarding and predator avoidance in male dollar sunfish (Lepomis marginatus). Copeia 1996:845851. 
Wildsmith, M. D., T. H. Rose, I. C. Potter, R. M. Warwick, K. R. Clarke, and F. J. Valesini. 2009. Changes in the benthic macroinvertebrate fauna of a large microtidal estuary following extreme modifications aimed at reducing eutrophication. Marine Pollution Bulletin 58:1250-1262. 
Table 1: Means and standard errors for the environmental variables measured at each centrarchid nest and random site. Significant Kruskal-Wallis tests $(\alpha=0.003)$ followed with pair-wise MannWhitney tests (significant differences denoted by lower-case numerals). Species coded as rock bass (AMRU), redbreast sunfish (LEAU), longear sunfish (LEME), and smallmouth bass (MIDO), and random sites (Ran).

\begin{tabular}{|c|c|c|c|c|c|c|c|c|c|}
\hline & & \multicolumn{2}{|c|}{$\underline{\text { Male Size }(\mathrm{cm})}$} & \multicolumn{2}{|c|}{$\underline{\text { Depth }(\mathrm{cm})}$} & \multicolumn{2}{|c|}{$\underline{\text { Dist Shore }(\mathrm{cm})}$} & \multicolumn{2}{|c|}{$\underline{\text { Dist Nest (class) }}$} \\
\hline \multicolumn{2}{|c|}{ Kruskal-Wallis } & $\chi^{2}=64.90$ & $P<0.001$ & $\chi^{2}=25.15$ & $P<0.001$ & $\chi^{2}=50.57$ & $P<0.001$ & $\chi^{2}=148.12$ & $P<0.001$ \\
\hline Species & $\mathrm{n}$ & Mean & SE & Mean & SE & Mean & SE & Mean & SE \\
\hline AMRU & 31 & $13.38 \mathrm{a}$ & 0.35 & $51.53 \mathrm{a}$ & 2.51 & $379.36 \mathrm{a}$ & 31.58 & $5.58 \mathrm{ac}$ & 0.22 \\
\hline LEAU & 27 & $15.04 \mathrm{~b}$ & 0.27 & $52.89 \mathrm{a}$ & 3.00 & $374.60 \mathrm{a}$ & 39.80 & $5.19 \mathrm{a}$ & 0.30 \\
\hline LEME & 97 & $12.20 \mathrm{c}$ & 0.36 & $41.36 \mathrm{~b}$ & 1.44 & $366.34 \mathrm{a}$ & 20.12 & $3.33 \mathrm{~b}$ & 0.17 \\
\hline MIDO & 8 & $21.50 \mathrm{~d}$ & 1.30 & $60.42 \mathrm{a}$ & 5.10 & $414.97 \mathrm{ab}$ & 66.14 & $5.75 \mathrm{ac}$ & 0.25 \\
\hline \multirow[t]{3}{*}{ Ran } & 97 & N/A & N/A & $63.72 \mathrm{a}$ & 5.00 & $748.93 \mathrm{~b}$ & 45.71 & $5.91 \mathrm{c}$ & 0.04 \\
\hline & & \multicolumn{2}{|c|}{ Dist Cover (class) } & \multicolumn{2}{|c|}{ Dist Pool (class) } & \multicolumn{2}{|c|}{ Velocity $(\mathrm{cm} / \mathrm{s})$} & \multicolumn{2}{|c|}{ Canopy Cover (\%) } \\
\hline & & $\chi^{2}=21.61$ & $P<0.001$ & $\chi^{2}=9.37$ & $P=0.053$ & $\chi^{2}=50.34$ & $P<0.001$ & $\chi^{2}=4.86$ & $P=0.302$ \\
\hline AMRU & 31 & $4.26 \mathrm{ab}$ & 0.38 & 4.10 & 0.24 & $6.74 \mathrm{a}$ & 0.82 & 22.90 & 5.37 \\
\hline LEAU & 27 & $3.19 \mathrm{~b}$ & 0.41 & 3.59 & 0.20 & $2.92 \mathrm{~b}$ & 0.61 & 13.10 & 4.94 \\
\hline LEME & 97 & $4.43 \mathrm{a}$ & 0.19 & 3.71 & 0.14 & $2.01 \mathrm{~b}$ & 0.24 & 19.30 & 3.22 \\
\hline MIDO & 8 & $2.25 \mathrm{~b}$ & 0.62 & 3.75 & 0.53 & $4.21 \mathrm{ab}$ & 1.67 & 31.90 & 12.50 \\
\hline \multirow[t]{3}{*}{ Ran } & 97 & $4.68 \mathrm{a}$ & 0.16 & 3.36 & 0.20 & $6.76 \mathrm{a}$ & 0.66 & 20.60 & 3.27 \\
\hline & & \multicolumn{2}{|c|}{ Clay/Silt Env (\%) } & \multicolumn{2}{|c|}{$\underline{\text { Sand Env }(\%)}$} & \multicolumn{2}{|c|}{ Gravel Env (\%) } & \multicolumn{2}{|c|}{ Cobble Env (\%) } \\
\hline & & $\chi^{2}=31.72$ & $P<0.001$ & $\chi^{2}=22.49$ & $P<0.001$ & $\chi^{2}=18.23$ & $P=0.001$ & $\chi^{2}=10.90$ & $P=0.028$ \\
\hline AMRU & 31 & 50.65 a & 3.85 & $6.13 \mathrm{a}$ & 1.95 & $4.52 \mathrm{ab}$ & 1.12 & 38.71 & 3.20 \\
\hline LEAU & 27 & $40.37 \mathrm{ab}$ & 4.54 & $15.93 \mathrm{~b}$ & 2.98 & $1.11 \mathrm{a}$ & 0.82 & 42.59 & 3.23 \\
\hline LEME & 97 & $42.58 \mathrm{a}$ & 2.37 & $13.71 \mathrm{~b}$ & 1.09 & $3.81 \mathrm{ab}$ & 0.63 & 40.31 & 1.67 \\
\hline MIDO & 8 & $62.50 \mathrm{a}$ & 10.31 & $8.75 \mathrm{ab}$ & 2.95 & $0.00 \mathrm{ab}$ & 0.00 & 28.75 & 7.89 \\
\hline \multirow[t]{3}{*}{ Ran } & 97 & $29.28 \mathrm{~b}$ & 2.77 & $16.91 \mathrm{~b}$ & 1.32 & $8.14 \mathrm{~b}$ & 1.23 & 45.67 & 2.20 \\
\hline & & \multicolumn{2}{|c|}{ Clay/Silt Nest (\%) } & \multicolumn{2}{|c|}{$\underline{\text { Sand Nest }(\%)}$} & \multicolumn{2}{|c|}{ Gravel Nest (\%) } & \multicolumn{2}{|c|}{$\underline{\text { Cobble Nest }(\%)}$} \\
\hline & & $\chi^{2}=5.75$ & $P=0.124$ & $\chi^{2}=9.70$ & $P=0.021$ & $\chi^{2}=12.30$ & $P=0.006$ & $\chi^{2}=18.89$ & $P<0.001$ \\
\hline AMRU & 31 & 2.58 & 1.13 & 8.06 & 2.20 & 37.10 & 4.64 & $52.58 \mathrm{a}$ & 4.75 \\
\hline LEAU & 27 & 2.22 & 0.97 & 16.30 & 4.37 & 52.59 & 5.02 & $28.89 \mathrm{~b}$ & 4.44 \\
\hline LEME & 97 & 1.44 & 0.49 & 9.90 & 0.92 & 37.01 & 2.05 & $51.65 \mathrm{~b}$ & 2.17 \\
\hline MIDO & 8 & 5.00 & 2.67 & 30.00 & 10.18 & 25.00 & 8.86 & $40.00 \mathrm{ab}$ & 10.69 \\
\hline
\end{tabular}


Table 2: Candidate models for nest site selection in the four nesting species of centrarchids, with the associated Akaike information criterion values adjusted for small sample size $\left(\mathrm{AIC}_{\mathrm{c}}\right)$, estimable parameters $(\mathrm{K}), \Delta_{\mathrm{i}}\left(\mid \mathrm{AIC} \mathrm{C}_{\mathrm{i}}-\mathrm{AIC}\right.$ lowest $\left.\mid\right)$, and relative model weights $\left(\mathrm{w}_{\mathrm{i}}\right)$. Models based on distance to nearest nest (DN), distance to cover (DC), distance to deepwater (DD), distance to shore (DS), water depth (WD), water velocity(WV), canopy cover (CC), silt and clay proportion (ST), sand proportion (SD), gravel proportion (GR), and cobble and bedrock proportion (CO). Candidate models with the lowest $\Delta_{\mathrm{i}}$ are given with standard errors in the footnotes.

\begin{tabular}{ccccccccc}
\hline Species & Model & Structure & K & $\mathrm{AIC}_{\mathrm{c}}$ & $\Delta_{\mathrm{i}}$ & $\mathrm{W}_{\mathrm{i}}$ & $\mathrm{Adj}_{\mathrm{R}} \mathrm{R}^{2}$ \\
\hline Longear sunfish & 5 & $\mathrm{Y}=14.204-2.278(\mathrm{DN})-0.003(\mathrm{DS})-0.006(\mathrm{WD})-0.020(\mathrm{CC})^{\mathrm{a}}$ & 6 & 106.76 & 0.00 & 0.909 & 0.624 \\
& 2 & $\mathrm{Y}=11.17-1.850(\mathrm{DN})-0.020(\mathrm{WD})-0.173(\mathrm{WV})$ & 5 & 112.47 & 5.71 & 0.052 & 0.602 \\
& 4 & $\mathrm{Y}=13.392-0.310(\mathrm{DC})-2.192(\mathrm{DN})-0.161(\mathrm{WV})$ & 5 & 113.19 & 6.43 & 0.037 & 0.598 \\
& 1 & $\mathrm{Y}=12.734-2.432(\mathrm{DN})$ & 3 & 119.27 & 12.51 & 0.002 & 0.567 \\
& 8 & $\mathrm{Y}=13.028-2.431(\mathrm{DN})-0.008(\mathrm{CC})-0.023(\mathrm{GR})$ & 5 & 121.27 & 14.51 & 0.001 & 0.563 \\
& 3 & $\mathrm{Y}=2.301-0.004(\mathrm{DS})-0.061(\mathrm{GR})$ & 4 & 208.95 & 102.19 & 0.000 & 0.231 \\
& 6 & $\mathrm{Y}=1.149-0.161(\mathrm{DC})+0.276(\mathrm{WV})+0.016(\mathrm{ST})$ & 5 & 220.93 & 114.17 & 0.000 & 0.186 \\
& 7 & $\mathrm{Y}=-0.757-0.287(\mathrm{WV})+0.026(\mathrm{ST})+0.020(\mathrm{CO})$ & 5 & 221.32 & 114.56 & 0.000 & 0.183 \\
& 14 & $\mathrm{Y}=-0.472-0.050(\mathrm{DC})-0.003(\mathrm{DS})+0.029(\mathrm{ST})$ & 5 & 119.46 & 0.00 & 0.965 & 0.146 \\
& 11 & $\mathrm{Y}=-0.140-0.093(\mathrm{SD})$ & & 126.45 & 6.99 & 0.029 & 0.112 \\
& 16 & $\mathrm{Y}=-0.017-0.001(\mathrm{WV})-0.089(\mathrm{SD})-0.025(\mathrm{GR})$ & 5 & 130.78 & 11.32 & 0.003 & 0.057 \\
& 15 & $\mathrm{Y}=-1.526-0.017(\mathrm{WD})+0.002(\mathrm{CC})+0.033(\mathrm{ST})$ & 5 & 131.44 & 11.98 & 0.002 & 0.043 \\
& 10 & $\mathrm{Y}=2.604-0.560(\mathrm{DN})-0.009(\mathrm{WD})$ & 4 & 142.75 & 23.29 & 0.000 & -0.022 \\
& 12 & $\mathrm{Y}=0.275-0.156(\mathrm{DC})-0.017(\mathrm{CO})$ & 4 & 144.95 & 25.49 & 0.000 & -0.039 \\
& 13 & $\mathrm{Y}=-1.462+0.194(\mathrm{DD})-0.004(\mathrm{WD})-0.023(\mathrm{WV})$ & 5 & 147.60 & 28.14 & 0.000 & -0.076 \\
& 9 & $\mathrm{Y}=-0.036-0.117(\mathrm{DC})-0.009(\mathrm{WD})-0.014(\mathrm{WV})$ & 5 & 148.76 & 29.30 & 0.000 & -0.084 \\
\hline
\end{tabular}


Table 2 continued

\begin{tabular}{cccccccc}
\hline Species & Model & Structure & $\mathrm{K}$ & $\mathrm{AIC}_{\mathrm{c}}$ & $\Delta_{\mathrm{i}}$ & $\mathrm{W}_{\mathrm{i}}$ & $\mathrm{Adj}_{\mathrm{R}} \mathrm{R}^{2}$ \\
\hline Redbreast sunfish & 17 & $\mathrm{Y}=6.846-0.961(\mathrm{DN})-0.463(\mathrm{DC})-0.181(\mathrm{WV})^{\mathrm{c}}$ & 5 & 105.32 & 0.00 & 0.976 & 0.178 \\
& 24 & $\mathrm{Y}=0.581-0.003(\mathrm{DS})+0.049(\mathrm{DD})-0.132(\mathrm{WV})$ & 5 & 114.94 & 9.62 & 0.008 & 0.095 \\
& 21 & $\mathrm{Y}=1.553-0.438(\mathrm{DC})-0.005(\mathrm{WD})-0.178(\mathrm{WV})$ & 5 & 114.96 & 9.64 & 0.008 & 0.095 \\
& 18 & $\mathrm{Y}=0.965-0.020(\mathrm{WD})-0.141(\mathrm{WV})-0.140(\mathrm{GR})$ & 5 & 115.18 & 9.86 & 0.007 & 0.092 \\
& 19 & $\mathrm{Y}=0.659-0.453(\mathrm{DC})-0.002(\mathrm{WD})$ & 4 & 123.20 & 17.88 & 0.000 & 0.038 \\
& 20 & $\mathrm{Y}=-0.355-0.008(\mathrm{CC})-0.171(\mathrm{WV})$ & 4 & 124.03 & 18.71 & 0.000 & 0.024 \\
Smallmouth bass & 22 & $\mathrm{Y}=3.327-0.799(\mathrm{DN})-0.008(\mathrm{WD})+0.012(\mathrm{ST})$ & 5 & 125.57 & 20.25 & 0.000 & 0.002 \\
& 23 & $\mathrm{Y}=-1.913+0.086(\mathrm{DD})-0.010(\mathrm{CC})+0.015(\mathrm{ST})$ & 5 & 134.51 & 29.19 & 0.000 & -0.084 \\
& 32 & $\mathrm{Y}=1.104-0.879(\mathrm{DC})-0.108(\mathrm{WV})$ & 4 & 59.62 & 0.00 & 0.522 & 0.135 \\
& 29 & $\mathrm{Y}=1.104-0.804(\mathrm{DC})-0.002(\mathrm{DS})$ & 4 & 59.96 & 0.34 & 0.441 & 0.125 \\
& 30 & $\mathrm{Y}=-2.039-0.086(\mathrm{WV})$ & 3 & 65.13 & 5.51 & 0.033 & 0.078 \\
& 26 & $\mathrm{Y}=-0.948-0.002(\mathrm{DS})-0.057(\mathrm{WV})$ & 4 & 70.24 & 10.62 & 0.003 & -0.260 \\
& 27 & $\mathrm{Y}=-1.015-0.825(\mathrm{DC})-0.056(\mathrm{WV})+0.038(\mathrm{ST})$ & 5 & 72.18 & 12.56 & 0.001 & -0.057 \\
& 25 & $\mathrm{Y}=0.401-0.896(\mathrm{DC})+0.002(\mathrm{WD})+0.003(\mathrm{CC})$ & 5 & 79.10 & 19.48 & 0.000 & -0.279 \\
& 31 & $\mathrm{Y}=-0.398-0.002(\mathrm{DS})+0.001(\mathrm{WD})-0.028(\mathrm{CO})$ & 5 & 86.85 & 27.23 & 0.000 & -0.512 \\
& 28 & $\mathrm{Y}=-1.695+0.073(\mathrm{DD})+0.011(\mathrm{CC})-0.035(\mathrm{CO})$ & 5 & 88.68 & 29.06 & 0.000 & -0.577 \\
\hline
\end{tabular}

\footnotetext{
${ }^{\mathrm{a}} \mathrm{Y}=(14.204 \pm 2.472)-(2.278 \pm 0.413) \mathrm{DN}-(0.003 \pm 0.001) \mathrm{DS}-(0.006 \pm 0.010) \mathrm{WD}-(0.020 \pm 0.009) \mathrm{CC}$

${ }^{\mathrm{b}} \mathrm{Y}=(-0.472 \pm 0.737)-(0.050 \pm 0.132) \mathrm{DC}-(0.003 \pm 0.000) \mathrm{DS}+(0.029 \pm 0.009) \mathrm{ST}$

${ }^{\mathrm{c}} \mathrm{Y}=(6.846 \pm 2.404)-(0.961 \pm 0.386) \mathrm{DN}-(0.463 \pm 0.138) \mathrm{DC}-(0.181 \pm 0.072) \mathrm{WV}$

${ }^{\mathrm{d}} \mathrm{Y}=(1.104 \pm 0.946)-(0.879 \pm 0.280) \mathrm{DC}-(0.108 \pm 0.091) \mathrm{WV}$

${ }^{\mathrm{e}} \mathrm{Y}=(1.104 \pm 1.104)-(0.804 \pm 0.288) \mathrm{DC}-(0.002 \pm 0.001) \mathrm{DS}$
} 
Table 3: Candidate models for nest success (presence of eggs) in longear sunfish (Lepomis megalotis) and rock bass (Ambloplites rupestris), with the associated Akaike information criterion values adjusted for small sample size (AIC $\mathrm{c}_{\mathrm{c}}$ ), estimable parameters $(\mathrm{K}), \Delta_{\mathrm{i}}$ $\left(\mid \mathrm{AIC}_{\mathrm{i}}-\mathrm{AIC} \mathrm{lowest}_{\mid}\right)$, and relative model weights $\left(\mathrm{w}_{\mathrm{i}}\right)$. Models based on male size (MS), nesting date (DA), distance to nearest nest (DN), distance to cover (DC), distance to deepwater (DD), distance to shore (DS), water depth (WD), water velocity (WV), canopy cover (CC), silt/clay proportion around nest (ST), silt/clay proportion in nest (SN), sand proportion around nest (SD), gravel proportion around nest (GR), gravel proportion in nest (GN), and cobble/bedrock proportion around nest (CO). Candidate models with the lowest $\Delta_{\mathrm{i}}$ are given with standard errors in the footnotes.

\begin{tabular}{cccccccc}
\hline Species & Model & Structure & $\mathrm{K}$ & $\mathrm{AIC}_{\mathrm{c}}$ & $\Delta_{\mathrm{i}}$ & $\mathrm{W}_{\mathrm{i}}$ & $\mathrm{Adj}_{.} \mathrm{R}^{2}$ \\
\hline Longear sunfish & 3 & $\mathrm{Y}=-1.173+0.002(\mathrm{DS})-0.024(\mathrm{GR})^{\mathrm{a}}$ & 4 & 127.8 & 1.31 & 0.323 & 0.047 \\
& 4 & $\mathrm{Y}=-2.238+0.313(\mathrm{DC})+0.046(\mathrm{DN})-0.010(\mathrm{WV})^{\mathrm{b}}$ & 5 & 126.5 & 0.00 & 0.275 & 0.047 \\
& 6 & $\mathrm{Y}=-2.128+0.289(\mathrm{DC})-0.006(\mathrm{WV})+0.003(\mathrm{ST})^{\mathrm{c}}$ & 5 & 126.5 & 0.03 & 0.272 & 0.021 \\
& 8 & $\mathrm{Y}=-1.173+0.001(\mathrm{DS})+0.001(\mathrm{WD})-0.024(\mathrm{GN})$ & 5 & 130.2 & 3.70 & 0.043 & 0.018 \\
& 7 & $\mathrm{Y}=-0.892+0.005(\mathrm{WD})-0.042(\mathrm{MS})+0.012(\mathrm{ST})$ & 5 & 130.3 & 3.81 & 0.041 & 0.017 \\
& 5 & $\mathrm{Y}=-0.307-0.022(\mathrm{DN})+0.001(\mathrm{DS})-0.014(\mathrm{WD})-0.011(\mathrm{CC})$ & 6 & 130.8 & 4.31 & 0.011 & 0.003 \\
& 1 & $\mathrm{Y}=0.957+0.002(\mathrm{DN})-0.029(\mathrm{MS})-0.002(\mathrm{DA})$ & 5 & 131.9 & 5.42 & 0.018 & -0.031 \\
& 2 & $\mathrm{Y}=-0.928-0.004(\mathrm{DN})+0.006(\mathrm{WD})+0.018(\mathrm{WV})$ & 5 & 132.2 & 5.74 & 0.016 & -0.004 \\
\hline
\end{tabular}


Table 3 continued

\begin{tabular}{cclccccc}
\hline Species & Model & \multicolumn{1}{c}{ Structure } & $\mathrm{K}$ & $\mathrm{AIC}_{\mathrm{c}}$ & $\Delta_{\mathrm{i}}$ & $\mathrm{W}_{\mathrm{i}}$ & ${\mathrm{Adj} . \mathrm{R}^{2}}$ \\
\hline Rock bass & 9 & $\mathrm{Y}=4.939+0.196(\mathrm{DC})-0.094(\mathrm{WD})-0.197(\mathrm{WV})^{\mathrm{d}}$ & 5 & 39.63 & 0.00 & 0.363 & 0.360 \\
& 13 & $\mathrm{Y}=5.322+0.297(\mathrm{DD})-0.103(\mathrm{WD})-0.236(\mathrm{WV})^{\mathrm{e}}$ & 5 & 39.71 & 0.08 & 0.349 & 0.354 \\
& 10 & $\mathrm{Y}=4.233+0.235(\mathrm{DN})-0.114(\mathrm{WD})^{\mathrm{f}}$ & 4 & 40.19 & 0.56 & 0.274 & 0.262 \\
& 11 & $\mathrm{Y}=-0.366+0.028(\mathrm{SD})$ & 3 & 47.52 & 7.89 & 0.007 & 0.016 \\
& 14 & $\mathrm{Y}=-2.483+0.403(\mathrm{DC})-0.003(\mathrm{DS})+0.004(\mathrm{DA})-1.739(\mathrm{SN})$ & 6 & 48.45 & 8.82 & 0.004 & 0.003 \\
& 12 & $\mathrm{Y}=-0.338+0.324(\mathrm{DC})-0.159(\mathrm{MS})+0.022(\mathrm{CO})$ & 5 & 51.27 & 11.64 & 0.001 & -0.009 \\
& 15 & $\mathrm{Y}=-1.889+0.287(\mathrm{DC})+0.002(\mathrm{DA})-0.017(\mathrm{ST})$ & 5 & 51.62 & 11.99 & 0.001 & -0.050 \\
& 16 & $\mathrm{Y}=-0.311+0.269(\mathrm{DN})-0.003(\mathrm{DS})-0.072(\mathrm{DD})$ & 5 & 53.02 & 13.39 & 0.000 & -0.060 \\
\hline
\end{tabular}

\footnotetext{
${ }^{\mathrm{a}} \mathrm{Y}=(-1.173 \pm 0.469)+(0.002 \pm 0.001) \mathrm{DS}-(0.024 \pm 0.036) \mathrm{GR}$

${ }^{\mathrm{b}} \mathrm{Y}=(-2.238 \pm 0.877)+(0.313 \pm 0.137) \mathrm{DC}+(0.046 \pm 0.134) \mathrm{DN}-(0.010 \pm 0.093) \mathrm{WV}$

${ }^{c} \mathrm{Y}=(-2.128 \pm 0.737)+(0.289 \pm 0.147) \mathrm{DC}-(0.006 \pm 0.094) \mathrm{WV}+(0.003 \pm 0.011) \mathrm{ST}$

${ }^{\mathrm{d}} \mathrm{Y}=(4.939 \pm 2.507)+(0.196 \pm 0.253) \mathrm{DC}-(0.094 \pm 0.043) \mathrm{WD}-(0.197 \pm 0.120) \mathrm{WV}$

${ }^{\mathrm{e}} \mathrm{Y}=(5.322 \pm 2.431)+(0.297 \pm 0.422) \mathrm{DD}-(0.103 \pm 0.048) \mathrm{WD}-(0.236 \pm 0.121) \mathrm{WV}$

${ }^{\mathrm{f}} \mathrm{Y}=(4.233 \pm 3.055)+(0.235 \pm 0.418) \mathrm{DN}-(0.114 \pm 0.044) \mathrm{WD}$
} 
Table 4: Candidate models for response to perceived harm in longear sunfish (Lepomis megalotis), with the associated Akaike information criterion values adjusted for small sample size $\left(\mathrm{AIC}_{\mathrm{c}}\right)$, estimable parameters $(\mathrm{K}), \Delta_{\mathrm{i}}\left(\left|\mathrm{AIC} \mathrm{C}_{\mathrm{i}}-\mathrm{AIC}_{\text {lowest }}\right|\right)$, and relative model weights $\left(\mathrm{w}_{\mathrm{i}}\right)$. Models for each of four response variables based on male size (MS), distance to nearest nest (DN), distance to cover (DC), distance to deepwater (DD), distance to shore (DS), water depth (WD), water velocity (WV), canopy cover (CC), gravel proportion around the nest (GR), and gravel proportion in the nest (GN). Candidate models with the lowest $\Delta_{\mathrm{i}}$ are given with standard errors in the footnotes.

\begin{tabular}{|c|c|c|c|c|c|c|c|}
\hline Response & Model & Structure & $\mathrm{K}$ & $\mathrm{AIC}_{\mathrm{c}}$ & $\Delta_{\mathrm{i}}$ & $\mathrm{w}_{\mathrm{i}}$ & Adj. $R^{2}$ \\
\hline \multirow[t]{10}{*}{ Return time (meter) } & 1 & $\mathrm{Y}=-33.242+2.602(\mathrm{DC})+3.910(\mathrm{DD})+2.258(\mathrm{MS})^{\mathrm{a}}$ & 5 & 501.33 & 0.00 & 0.374 & 0.150 \\
\hline & 8 & $\mathrm{Y}=2.800+4.466(\mathrm{DD})-0.090(\mathrm{CC})+0.720(\mathrm{GR})^{\mathrm{b}}$ & 5 & 502.88 & 1.55 & 0.172 & 0.108 \\
\hline & 5 & $\mathrm{Y}=-19.138+3.108(\mathrm{DD})+2.108(\mathrm{MS})+1.045(\mathrm{WV})$ & 5 & 503.97 & 2.64 & 0.100 & 0.082 \\
\hline & 4 & $\mathrm{Y}=-26.417+2.513(\mathrm{DN})+2.855(\mathrm{DC})+2.201(\mathrm{MS})$ & 5 & 504.09 & 2.76 & 0.094 & 0.075 \\
\hline & 2 & $Y=21.367+3.680(D D)-0.289(W D)-0.115(C C)$ & 5 & 504.26 & 2.93 & 0.087 & 0.060 \\
\hline & 7 & $\mathrm{Y}=-18.197+1.995(\mathrm{DC})+2.269(\mathrm{MS})+1.321(\mathrm{WV})$ & 5 & 505.15 & 3.82 & 0.055 & 0.045 \\
\hline & 6 & $\mathrm{Y}=20.827+2.275(\mathrm{DN})-0.230(\mathrm{WD})+1.232(\mathrm{WV})$ & 5 & 505.6 & 4.27 & 0.044 & 0.037 \\
\hline & 9 & $\mathrm{Y}=0.588-0.008(\mathrm{DS})-0.254(\mathrm{WD})+2.716(\mathrm{MS})$ & 5 & 506.22 & 4.89 & 0.032 & 0.027 \\
\hline & 10 & $\mathrm{Y}=13.303+2.220(\mathrm{DN})+1.562(\mathrm{WV})-0.060(\mathrm{GN})$ & 5 & 507 & 5.67 & 0.022 & 0.013 \\
\hline & 3 & $\mathrm{Y}=25.972+1.486(\mathrm{DC})-0.240(\mathrm{WD})-0.059(\mathrm{CC})$ & 5 & 507.38 & 6.05 & 0.018 & 0.007 \\
\hline
\end{tabular}


Table 4 continued

\begin{tabular}{|c|c|c|c|c|c|c|c|}
\hline Response & Model & Structure & $\mathrm{K}$ & $\mathrm{AIC}_{\mathrm{c}}$ & $\Delta_{\mathrm{i}}$ & $\mathrm{w}_{\mathrm{i}}$ & Adj. $R^{2}$ \\
\hline \multirow[t]{10}{*}{ Return time (nest) } & 6 & $\mathrm{Y}=15.332+4.681(\mathrm{DN})-0.0187(\mathrm{WD})+2.265(\mathrm{WV})^{\mathrm{c}}$ & 5 & 516.08 & 0.00 & 0.267 & 0.170 \\
\hline & 10 & $\mathrm{Y}=8.575+4.520(\mathrm{DN})+2.552(\mathrm{WV})-0.023(\mathrm{GN})^{\mathrm{d}}$ & 5 & 516.94 & 0.86 & 0.173 & 0.158 \\
\hline & 4 & $\mathrm{Y}=-22.031+4.906(\mathrm{DN})+3.095(\mathrm{DC})+1.634(\mathrm{MS})^{\mathrm{e}}$ & 5 & 517.4 & 1.32 & 0.138 & 0.151 \\
\hline & 8 & $Y=4.549+6.160(\mathrm{DD})-0.170(\mathrm{CC})+0.622(\mathrm{GR})^{\mathrm{f}}$ & 5 & 517.45 & 1.37 & 0.134 & 0.150 \\
\hline & 2 & $\mathrm{Y}=23.533+5.447(\mathrm{DD})-0.310(\mathrm{WD})-0.206(\mathrm{CC})^{\mathrm{g}}$ & 5 & 517.6 & 1.52 & 0.125 & 0.148 \\
\hline & 1 & $\mathrm{Y}=-23.446+2.298(\mathrm{DC})+4.952(\mathrm{DD})+1.734(\mathrm{MS})$ & 5 & 518.64 & 2.56 & 0.074 & 0.105 \\
\hline & 5 & $\mathrm{Y}=-11.782+3.985(\mathrm{DD})+1.625(\mathrm{MS})+1.667(\mathrm{WV})$ & 5 & 518.88 & 2.80 & 0.066 & 0.094 \\
\hline & 7 & $\mathrm{Y}=-5.137+1.476(\mathrm{DC})+1.757(\mathrm{MS})+2.098(\mathrm{WV})$ & 5 & 522.08 & 6.00 & 0.013 & 0.032 \\
\hline & 3 & $\mathrm{Y}=37.073+1.1572(\mathrm{DC})-0.291(\mathrm{WD})-0.126(\mathrm{CC})$ & 5 & 524.03 & 7.95 & 0.005 & -0.002 \\
\hline & 9 & $\mathrm{Y}=10.780-0.016(\mathrm{DS})-0.174(\mathrm{WD})+2.314(\mathrm{MS})$ & 5 & 524.1 & 8.02 & 0.005 & -0.003 \\
\hline \multirow[t]{10}{*}{ Abandonment threshold } & 9 & $\mathrm{Y}=536.396+0.109(\mathrm{DS})-2.267(\mathrm{WD})-17.058(\mathrm{MS})^{\mathrm{h}}$ & 5 & 665.49 & 0.00 & 0.763 & 0.241 \\
\hline & 2 & $\mathrm{Y}=413.469-4.288(\mathrm{DD})-2.914(\mathrm{WD})-0.464(\mathrm{CC})$ & 5 & 670.73 & 5.24 & 0.056 & 0.168 \\
\hline & 6 & $\mathrm{Y}=387.896-2.663(\mathrm{DN})-2.445(\mathrm{WD})-6.277(\mathrm{WV})$ & 5 & 670.93 & 5.44 & 0.050 & 0.165 \\
\hline & 3 & $\mathrm{Y}=393.373+0.552(\mathrm{DC})-2.855(\mathrm{WD})-0.522(\mathrm{CC})$ & 5 & 671.03 & 5.54 & 0.048 & 0.164 \\
\hline & 10 & $\mathrm{Y}=336.557+1.845(\mathrm{DN})-3.612(\mathrm{WV})-1.744(\mathrm{GN})$ & 5 & 671.03 & 5.54 & 0.048 & 0.164 \\
\hline & 7 & $\mathrm{Y}=451.024+7.230(\mathrm{DC})-16.928(\mathrm{MS})-2.494(\mathrm{WV})$ & 5 & 674.18 & 8.69 & 0.010 & 0.116 \\
\hline & 4 & $\mathrm{Y}=460.703-3.353(\mathrm{DN})+5.991(\mathrm{DC})-16.819(\mathrm{MS})$ & 5 & 674.23 & 8.74 & 0.010 & 0.116 \\
\hline & 1 & $\mathrm{Y}=444.438+6.974(\mathrm{DC})+0.495(\mathrm{DD})-16.869(\mathrm{MS})$ & 5 & 674.46 & 8.97 & 0.009 & 0.112 \\
\hline & 5 & $\mathrm{Y}=487.341+0.010(\mathrm{DD})-17.427(\mathrm{MS})-1.975(\mathrm{WV})$ & 5 & 675.56 & 10.07 & 0.005 & 0.095 \\
\hline & 8 & $\mathrm{Y}=251.035+0.228(\mathrm{DD})+0.031(\mathrm{CC})+3.324(\mathrm{GR})$ & 5 & 677.47 & 11.98 & 0.002 & 0.064 \\
\hline
\end{tabular}


Table 4 continued

\begin{tabular}{|c|c|c|c|c|c|c|c|}
\hline Response & Model & Structure & $\mathrm{K}$ & $\mathrm{AIC}_{\mathrm{c}}$ & $\Delta_{\mathrm{i}}$ & $\mathrm{w}_{\mathrm{i}}$ & Adj. $R^{2}$ \\
\hline \multirow[t]{10}{*}{ Refuge distance } & 7 & $\mathrm{Y}=9.784+1.415(\mathrm{DC})-0.567(\mathrm{MS})-0.713(\mathrm{WV})^{\mathrm{i}}$ & 5 & 353.95 & 0.00 & 0.835 & 0.277 \\
\hline & 3 & $Y=-2.501+1.609(\mathrm{DC})+0.076(\mathrm{WD})-0.005(\mathrm{CC})$ & 5 & 358.99 & 5.04 & 0.067 & 0.210 \\
\hline & 4 & $\mathrm{Y}=7.000+0.365(\mathrm{DN})+1.426(\mathrm{DC})-0.556(\mathrm{MS})$ & 5 & 359.39 & 5.44 & 0.055 & 0.204 \\
\hline & 1 & $\mathrm{Y}=8.286+1.331(\mathrm{DC})+0.055(\mathrm{DD})-0.550(\mathrm{MS})$ & 5 & 360.09 & 6.14 & 0.039 & 0.194 \\
\hline & 5 & $\mathrm{Y}=16.734+0.046(\mathrm{DD})-0.665(\mathrm{MS})-0.618(\mathrm{WV})$ & 5 & 367.03 & 13.08 & 0.001 & 0.095 \\
\hline & 9 & $\mathrm{Y}=15.862+0.008(\mathrm{DS})-0.005(\mathrm{WD})-0.877(\mathrm{MS})$ & 5 & 367.24 & 13.29 & 0.001 & 0.087 \\
\hline & 6 & $\mathrm{Y}=10.160-0.187(\mathrm{DN})-0.020(\mathrm{WD})-0.654(\mathrm{WV})$ & 5 & 368.54 & 14.59 & 0.001 & 0.065 \\
\hline & 10 & $\mathrm{Y}=9.091-0.265(\mathrm{DN})-0.613(\mathrm{WV})+0.011(\mathrm{GN})$ & 5 & 368.6 & 14.65 & 0.001 & 0.064 \\
\hline & 8 & $\mathrm{Y}=7.310-0.025(\mathrm{DD})-0.013(\mathrm{CC})+0.117(\mathrm{GR})$ & 5 & 371.33 & 17.38 & 0.000 & 0.019 \\
\hline & 2 & $\mathrm{Y}=8.381-0.131(\mathrm{DD})-0.007(\mathrm{WD})-0.007(\mathrm{CC})$ & 5 & 372.23 & 18.28 & 0.000 & 0.003 \\
\hline
\end{tabular}

\footnotetext{
${ }^{\mathrm{a}} \mathrm{Y}=(-33.242 \pm 22.822)+(2.602 \pm 1.400) \mathrm{DC}+(3.910 \pm 1.708) \mathrm{DD}+(2.258 \pm 1.626) \mathrm{MS}$

${ }^{\mathrm{b}} \mathrm{Y}=(2.800 \pm 7.585)+(4.466 \pm 1.868) \mathrm{DD}-(0.090 \pm 0.085) \mathrm{CC}+(0.720 \pm 0.401) \mathrm{GR}$

${ }^{\mathrm{c}} \mathrm{Y}=(15.332 \pm 10.555)+(4.681 \pm 1.729) \mathrm{DN}-(0.0187 \pm 0.204) \mathrm{WD}+(2.265 \pm 1.252) \mathrm{WV}$

${ }^{\mathrm{d}} \mathrm{Y}=(8.575 \pm 7.858)+(4.520 \pm 1.845) \mathrm{DN}+(2.552 \pm 1.221) \mathrm{WV}-(0.023 \pm 0.147) \mathrm{GN}$

${ }^{\mathrm{e}} \mathrm{Y}=(-22.031 \pm 25.897)+(4.906 \pm 1.792) \mathrm{DN}+(3.095 \pm 1.672) \mathrm{DC}+(1.634 \pm 1.872) \mathrm{MS}$

${ }^{\mathrm{f}} \mathrm{Y}=(4.549 \pm 8.618)+(6.160 \pm 2.123) \mathrm{DD}-(0.170 \pm 0.097) \mathrm{CC}+(0.622 \pm 0.456) \mathrm{GR}$

${ }^{\mathrm{g}} \mathrm{Y}=(23.533 \pm 14.112)+(5.447 \pm 2.093) \mathrm{DD}-(0.310 \pm 0.237) \mathrm{WD}-(0.206 \pm 0.109) \mathrm{CC}$

${ }^{\mathrm{h}} \mathrm{Y}=(536.396 \pm 87.396)+(0.109 \pm 0.063) \mathrm{DS}-(2.267 \pm 0.744) \mathrm{WD}-(17.058 \pm 7.112) \mathrm{MS}$

${ }^{\mathrm{i}} \mathrm{Y}=(9.784 \pm 5.930)+(1.415 \pm 0.382) \mathrm{DC}-(0.567 \pm 0.446) \mathrm{MS}-(0.713 \pm 0.290) \mathrm{WV}$
} 


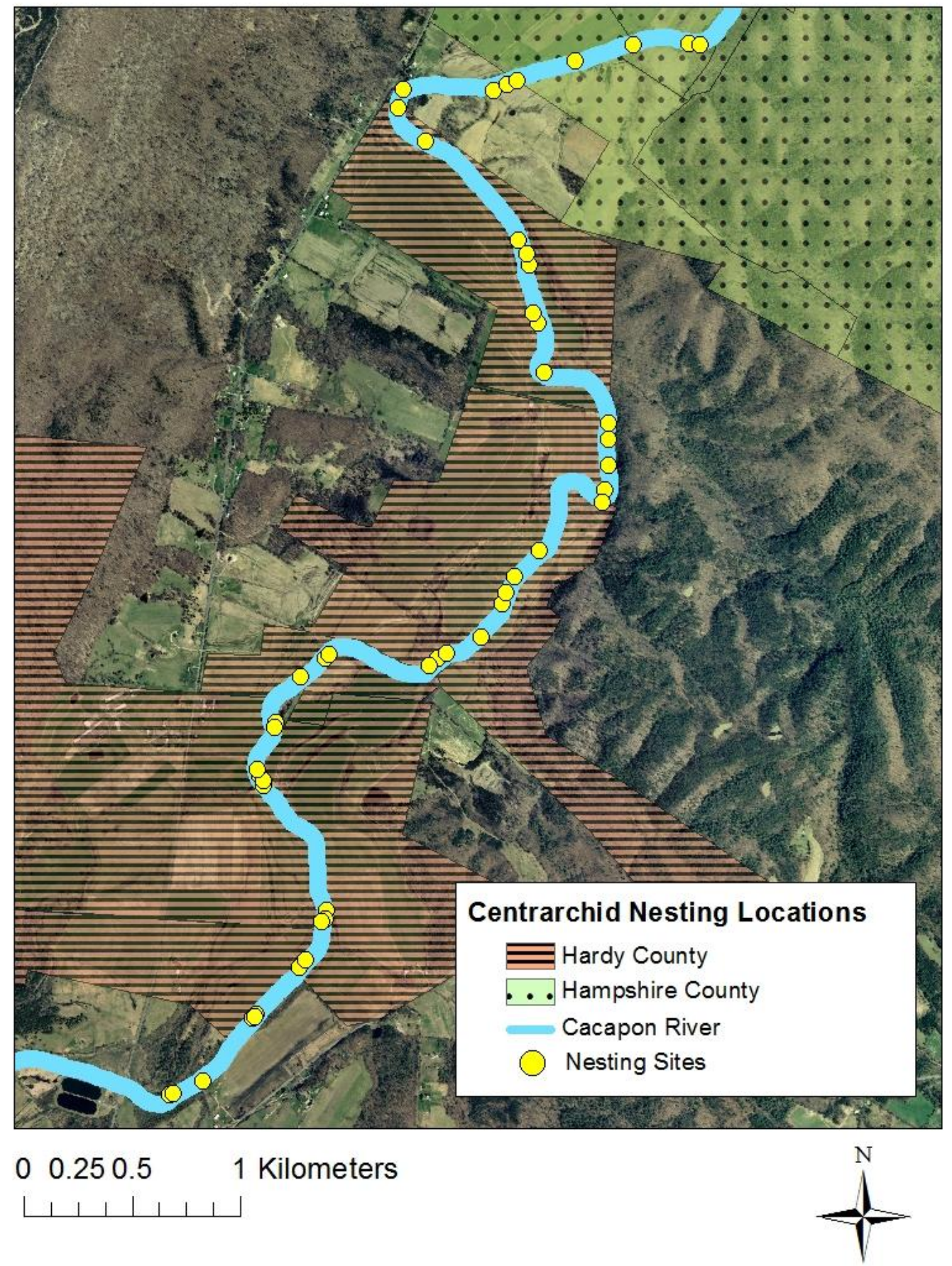

Figure 1: Map of the Cacapon River stretch that was surveyed for centrarchid nests, showing the sites where nests were found. Each labeled site represents any number of closely clustered nests, not individual nests. 


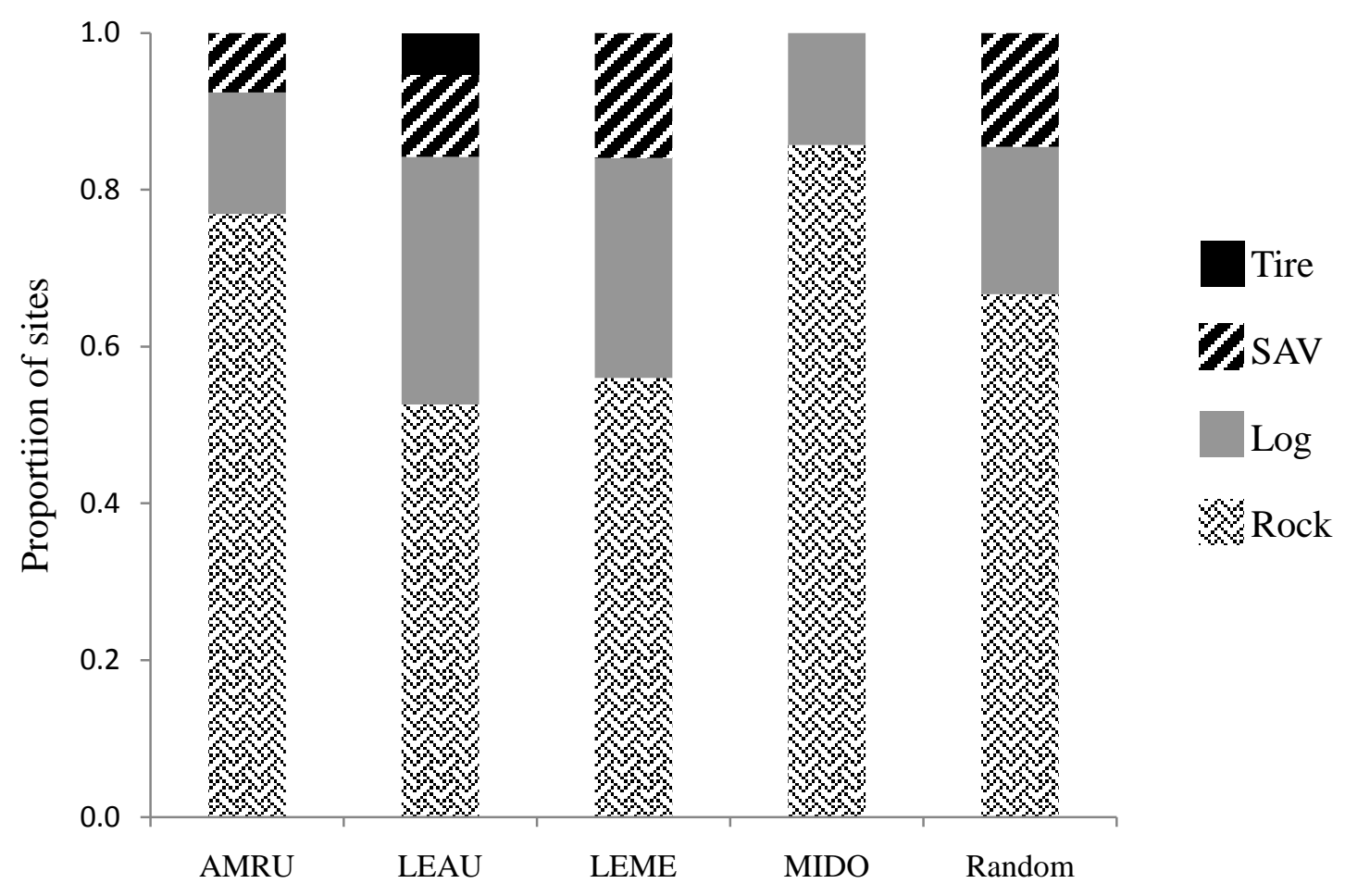

Figure 2: Proportion of objects that serve as the closest cover object from each centrarchid nest for rock bass (Ambloplites rupestris, AMRU), redbreast sunfish (Lepomis auritus, LEAU), longear sunfish (Lepomis megalotis, LEME), and smallmouth bass (Micropterus dolomieu, MIDO), and for random sites on the Cacapon River, WV, 2010. SAV=submerged aquatic vegetation. 


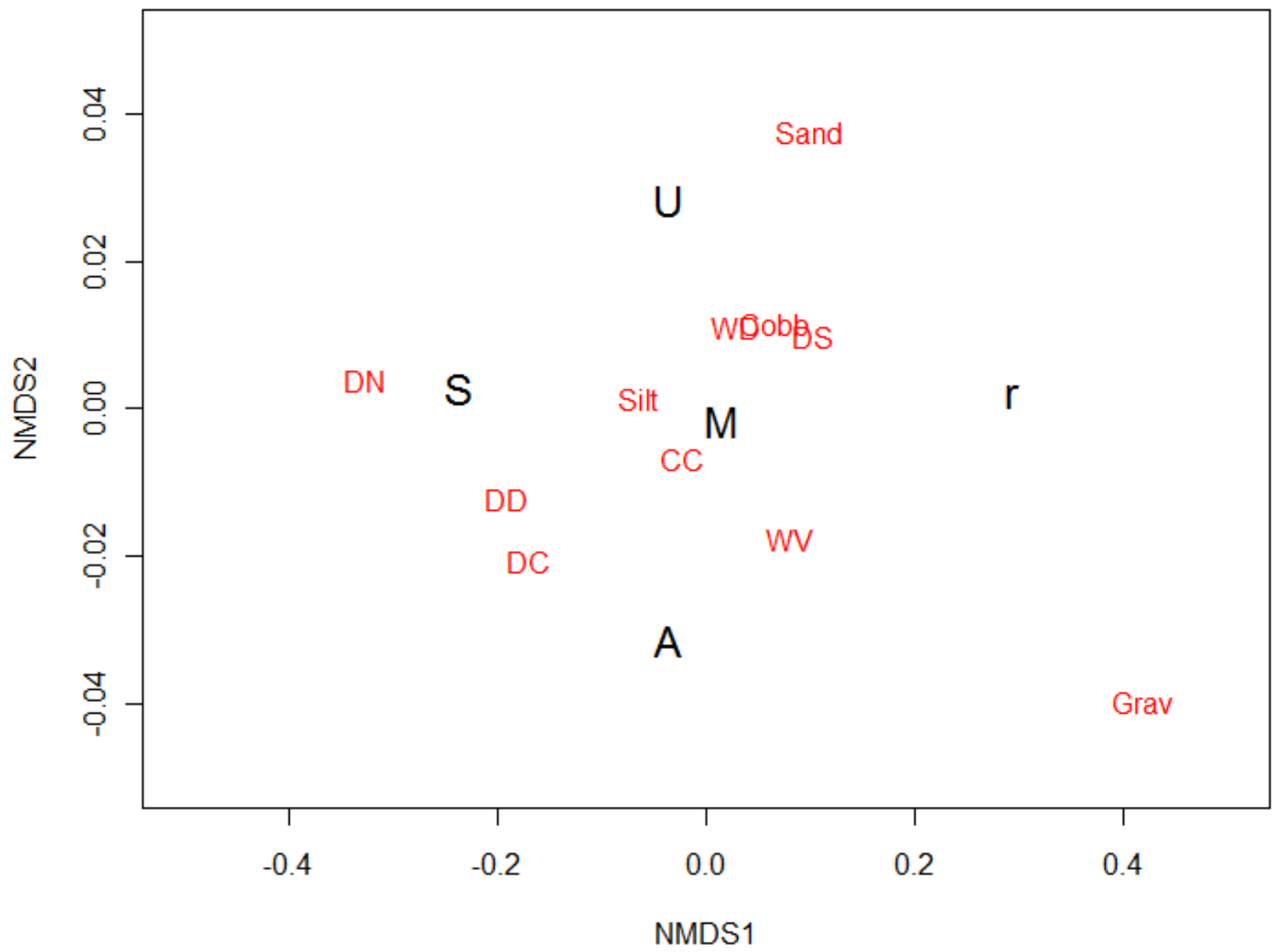

Figure 3: Nonmetric multidimensional scaling (NMDS) ordination plot $(\mathrm{k}=2)$ for longear sunfish nests (Lepomis megalotis, M), redbreast sunfish (L. auritus, $\mathrm{U}$ ), rock bass (Ambloplites rupestris, A), smallmouth bass (Micropterus dolomieu, S), and random sites (r), based on average values for each environmental variable within species. Overlay depicts weighted means of distance to nearest nest (DN), distance to cover (DC), distance to deepwater (DD), distance to shore (DS), water depth (WD), water velocity (WV), canopy cover (CC), silt and clay proportion (Silt), sand proportion (Sand), gravel proportion (Grav), and cobble and bedrock proportion (Cobb). 


\title{
CHAPTER IV
}

CONCLUSIONS, MANAGERIAL CONSIDERATIONS, AND FUTURE RESEARCH OPPORTUNITIES

\author{
Stephen Selego \\ sselego@gmail.com \\ West Virginia University \\ Division of Forestry and Natural Resources \\ PO Box 6125 \\ Morgantown, WV 26506
}

\author{
Written in the style of: \\ Restoration ecology
}




\section{Introduction}

Stream bank erosion, pollutant runoff, and channelization have had considerable, negative effects on the biotic communities of many of America's streams and rivers. Stream restoration is becoming increasing important for mitigating these effects (Berkman \& Rabeni 1986). Although all aquatic species are affected by these factors, most biotic assessments use benthic macroinvertebrate and/or fish communities to determine the success of restoration projects (Barbour et al. 1999). Such assessment is essential to furthering our understanding of restoration practices, in order to improve on techniques and prevent causing more harm than good (Opperman \& Merenlander 2004). In the Cacapon River, restoration practices were assessed using electrofishing for fishes (Fig. 1) and kick-sampling for benthic macroinvertebrates (Fig. 2), and a combination of non-parametric statistical tests and indices of biotic integrity.

Among the species affected by sedimentation are the substrate-nesting species of the family Centrarchidae. Although centrarchid nesting behavior (such as site selection and nest reuse) has been extensively studied, the majority of research has been conducted in lentic systems and within a limited geographic range (Gross \& Nowell 1980; Ridgway et al. 1991). Predation or threat response in nesting centrarchids is a relatively untouched topic, but one of importance given the degree of recreational activity in the Cacapon River and other similar systems (Mueller 1980). Extensive environmental data and threat-response behavior was collected for four species of centrarchids found nesting within the Cacapon River to address the topics mentioned above.

\section{Objectives}

The community-level response to stream restoration study was based on the following objectives, with the corresponding hypotheses listed below. 
1. Use a modified IBI to determine the health of the macroinvertebrate communities in the restoration, control, and reference stretches of the Cacapon River prior to, during, and following restoration efforts.

$\mathrm{H}_{0}$ : Macroinvertebrate IBI scores are identical among study stretches and among sampling seasons

$\mathrm{H}_{\mathrm{a}}$ : Macroinvertebrate IBI scores will differ among study stretches, and the restoration stretch score will increase following restoration efforts

2. Use two fish IBIs designed for the Mid-Atlantic region to determine the health of the fish communities in the restoration, control, and reference stretches of the Cacapon River prior to, during, and following restoration efforts.

$\mathrm{H}_{0}$ : Fish IBI scores are identical among study stretches and among sampling seasons

$\mathrm{H}_{\mathrm{a}}$ : Fish IBI scores will differ among study stretches, and the restoration stretch score will increase following restoration efforts

The Centrarchidae nesting behavior study was based on the following objectives, with the corresponding hypotheses listed below.

1. Collect environmental characteristic data from each centrarchid nest found, along with physical data on the male guarding each nest (size, species, etc.), within the study stretch of the Cacapon River to determine which characteristics affect nest location.

$\mathrm{H}_{0}$ : Centrarchid males nest indiscriminately within the study stretch

$\mathrm{H}_{\mathrm{a}}$ : Environmental and physical characteristics of the nest site and male will affect the location of nests; specifically, centrarchids will select sites with shallow water, minimal water velocity, and proximity to upstream cover objects

2. Monitor all centrarchid nests found to determine which received eggs, and which were abandoned before mating occurred, and determine which environmental and physical characteristics affect nest success.

$\mathrm{H}_{0}$ : Nest success is not based on environmental or physical characteristics of the nest site or male

$\mathrm{H}_{\mathrm{a}}$ : Nest success is largely based on specific characteristics, including male size, timing during the spawning season, and proximity to other centrarchid nests

3. Revisit all previously located nests to determine if male centrarchids are reusing previously constructed nests.

$\mathrm{H}_{0}$ : Male centrarchids are not preferentially reusing nests

$\mathrm{H}_{\mathrm{a}}$ : Male centrarchids are selectively reusing nests as opposed to constructing new nests 
4. Perform experimental predation response studies on at least one third of the centrarchid nests located, and record each male's behavior.

$\mathrm{H}_{0}$ : Behavioral response to the threat of predation will be independent of the corresponding environmental and physical characteristics of the nest site and male

$\mathrm{H}_{\mathrm{a}}$ : Behavioral response to threat of predation will reflect the fitness of the male, status of the guarded nest, and degree of protection available within the environment surrounding the nest

\section{Results}

\section{Response of aquatic taxa to stream restoration}

Fish collected from the Cacapon River sampling stretches were held in large bins (Fig. 3) and identified on-site (Fig. 4). The health of the fish community at each stretch was assessed using two mid-Atlantic drainage indices of biotic integrity (IBIs). The Daniels et al. (2002) IBI differentiated the control from the references stretches before and after restoration, with percent anomalies as one of the strongest metrics for stretch classification (Fig. 5). The McCormick et al. (2001) IBI did not differentiate, instead indicating the upstream control was similar to the reference stretches. All sites decreased in IBI score from 2009 (pre-restoration) to 2010 (postrestoration), including the restoration stretch. However, during-restoration sampling at the restoration stretch produced an IBI score far lower than from any other site during any of the sampling seasons. Therefore, while the restoration stretch has yet to approach the IBI score (and therefore fish community health) of the reference stretches, it has quickly recovered from the deleterious effects of the restoration process. Additionally, the mobile nature of fish may partially obscure the localized effects of restoration. Although sampling of this community should continue, the greatest focus should be placed on more sedentary species: specifically, macroinvertebrates (Berkman \& Rabeni 1986). 
Aquatic macroinvertebrates were also analyzed using an IBI, after identification to genus (Fig. 6). Macroinvertebrates responded more quickly to stream restoration than did fish. During all four sampling seasons, the IBI scores (calculated as rank sums of the eight metrics used) of the control stretches were lower than those of the reference stretches. During both of the prerestoration sampling seasons (Summer 2009 and Winter 2010), the restoration stretch most closely approximated the control stretches. During restoration, as was seen from the fish community, the macroinvertebrate IBI score from the restoration stretch decreased significantly, likely due to increased sedimentation and movement of substrate with heavy machinery. However, following restoration (Summer 2010), the restoration stretch recovered, and the corresponding IBI score was much closer to those from the reference stretches than from the control stretches.

Although macroinvertebrate communities are known to recolonize disturbed areas (such as restoration sites) quickly, the species detected shortly after a disturbance may not be representative of those detected years following the disturbance (Muotka et al. 2001). Therefore, while rapid and significant improvement in macroinvertebrate health at a restoration stretch is promising, many additional sampling years are required to adequately assess the ultimate impact the restoration project will have on the community. However, the Cacapon River restoration stretch following restoration supported higher abundances of many intolerant taxa than either reference stretch (Corydalidae, Ephemerellidae, and Tipulidae were all well represented), suggesting the restoration stretch is at least capable of supporting intolerant taxa in numbers that the stretch pre-restoration could not. 


\section{Centrarchidae nesting behavior}

Four species of centrarchids were observed nesting in the Cacapon River: longear sunfish (Lepomis megalotis), redbreast sunfish (Lepomis auritus) (Fig. 7), rock bass (Ambloplites rupestris), and smallmouth bass (Micropterus dolomieu). Several environmental variables were measured for each nest found, including distances to nearest cover object and nest, water velocity, canopy cover, and substrate composition. All four species nested on sites that were significantly different from random sites within the river based on permutational multivariate analysis of variance (PERMANOVA) (Wildsmith et al. 2009); therefore, site selection (nonrandom nesting) occurred in all species. Sites preferred by nesting centrarchids were generally visually distinguishable from non-nested sites (Fig. 8). Longear sunfish nested in habitat significantly different from the other three species, which nested in similar habitat. Specifically, longear sunfish nested closer to other centrarchids and farther from in-stream cover objects than males of other species (Fig. 9).

Nest site selection and nest success (the probability of a male of a particular species receiving eggs before it abandoned its nest) were linked to specific environmental variables for each centrarchid species using general linear models (glm) and Akaike Information Criterion adjusted for small sample size $\left(\mathrm{AIC}_{\mathrm{c}}\right)$ values (Bacheler et al. 2010). The best approximating models for each species included the variables listed below:

-Longear sunfish nest selection: distance to shore, distance to neighboring nest, water depth, and canopy cover

-Longear sunfish nest success: distance to cover object, distance to neighboring nest, water velocity, silt/clay around the nest, and gravel around the nest

-Rock bass nest selection: distance to shore, distance to cover object, and silt/clay around the nest 
-Rock bass nest success: distance to cover object, distance to neighboring nest, distance to deepwater, water velocity, and water depth

-Redbreast sunfish nest selection: distance to cover object, distance to neighboring nest, and water velocity

-Smallmouth bass nest selection: distance to cover object, water velocity, and silt/clay around the nest

Distance to neighboring nest and distance to cover object were important to nest site selection and nest success in multiple species. Therefore, future studies should contain additional variables regarding the number of nests and cover objects in the vicinity of each nest. However, the relative importance of these environmental variables on nest selection and nest success between the four species, and the importance of other variables, suggests that centrarchid diversity and fecundity would be highest in systems with high habitat heterogeneity. From a management perspective, maintaining multiple depth-velocity combinations and multiple types of cover objects in a lotic system should increase the number of centrarchid sport-fishes present. Although proportion of silt/clay around the nests of rock bass and smallmouth bass was higher than would be expected in nesting occurred at random, neither of these species were found nesting near heavily eroding banks. Therefore, restoration efforts that reduce sedimentation, reduce bank angle, and increase riparian vegetation should increase the abundances of these species within the stretch. 


\section{Centrarchid response to perceived harm}

The behavioral response of longear sunfish to perceived harm was studied by approaching male longear sunfish guarding nests until flight behavior was induced. The time before the male returned a) to within one meter of the nest, and b) to swimming over the nest were recorded. The distance from the observer to the nest (which first induced a flight response) and the maximum distance the male traveled from its nest were also measured. These responses were linked to the environmental variables measured in the previous section using general linear models $(\mathrm{glm})$ and Akaike Information Criterion adjusted for small sample size $\left(\mathrm{AIC}_{\mathrm{c}}\right)$ values. The best approximating models for each response variable included the parameters listed below:

-Distance to abandonment: male size, distance to shore, and water depth

-Flight distance/distance to refuge: male size, distance to cover object, and water velocity

-Time to return (meter): male size, distance to cover object, distance to deepwater, canopy cover, and gravel around the nest

-Time to return (full): male size, distance to cover object, distance to neighboring nest, distance to deepwater, water depth, water velocity, canopy cover, gravel within the nest, and gravel around the nest

Although human-induced flight behavior can be used to approximate centrarchid response to threat of predation, it is likely more related to centrarchid response to recreational activity (fishing, boating, etc.) on a river. Given the opportunity to expand upon this study, dummy herons (centrarchid predators) would be constructed to compare the response of males to human-shaped and heron-shaped threats (Winkelman 1996). As an additional project idea, the observed tendency for bluegill (Lepomis macrochirus) to depredate the eggs of redbreast sunfish over other centrarchid species could be tested experimentally. 


\section{LITERATURE CITED}

Bacheler, N. M., J. E. Hightower, S. M. Burdick, L. M. Paramore, J. A. Buckel, and K. H. Pollock. 2010. Using generalized linear models to estimate selectivity from short-term recoveries of tagged red drum Sciaenops ocellatus: effects of gear, fate, and regulation period. Fisheries Research 102:266-275.

Barbour, M. T., J. Gerritsen, B. D. Snyder, and J. B. Stribling. 1999. Rapid bioassessment protocols for use in streams and wadeable rivers: periphyton, benthic macroinvertebrates and fish, second edition. EPA 841-B-99-002. U.S. Environmental Protection Agency; Office of Water; Washington, D.C.

Berkman, H. E, and C. F. Rabeni. 1986. Biomonitors of stream quality in agricultural areas: fish versus invertebrates. Environmental Management 10:413-419.

Daniels, R. A., K. Riva-Murray, D. B. Halliwell, D. L. Vana-Miller, and M. D. Bilger. 2002. An index of biological integrity for northern mid-Atlantic slope drainages. Transactions of the American Fisheries Society 131:1044-1060.

Gross, M. R., and W. A. Nowell. 1980. The reproductive biology of rock bass, Ambloplites rupestris (Centrarchidae), in Lake Opinicon, Ontario. Copeia 1980:482-494.

McCormick, F. H., R. M. Hughes, P. R. Kaufmann, D. V. Peck, J. L. Stoddard, and A. T. Herlihy. 2001. Development of an index of biotic integrity for the Mid-Atlantic Highlands region. Transactions of the American Fisheries Society 130:857-877.

Mueller, G. 1980. Effects of recreational river traffic on nest defense by longear sunfish. Transactions of the American Fisheries Society 109:248-251. 
Muotka, T., R. Paavola, A. Haapala, M. Novikmee, and P. Laasonen. 2001. Long-term recovery of stream habitat structure and benthic invertebrate communities from in-stream restoration. Biological Conservation 105:243-253.

Opperman, J. J., and A. M. Merenlender. 2004. The effectiveness of riparian restoration for improving instream fish habitat in four hardwood-dominated California streams. North American Journal of Fisheries Management 24:822-834.

Ridgway, M. S., B. J. Shuter, and E. E. Post. 1991. The relative influence of body size and territorial behavior on nesting asynchrony in male smallmouth bass, Micropterus dolomieu (Pisces: Centrarchidae). Journal of Animal Ecology 60:665-681.

Winkelman, D. L. 1996. Reproduction under predatory threat: trade-offs between nest guarding and predator avoidance in male dollar sunfish (Lepomis marginatus). Copeia 1996:845851.

Wildsmith, M. D., T. H. Rose, I. C. Potter, R. M. Warwick, K. R. Clarke, and F. J. Valesini. 2009. Changes in the benthic macroinvertebrate fauna of a large microtidal estuary following extreme modeifications aimed at reducing eutrophication. Marine Pollution Bulletin 58:1250-1262. 


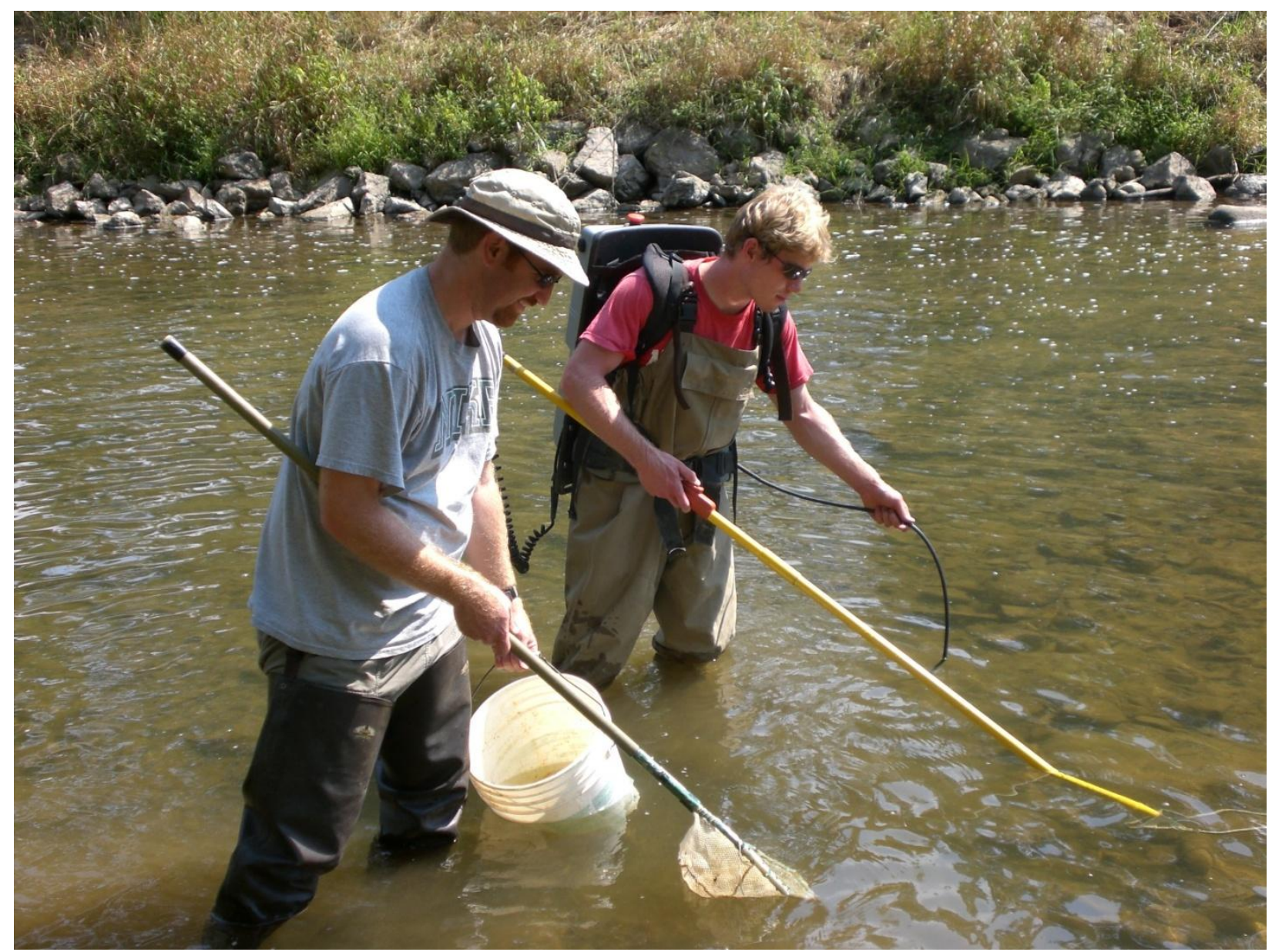

Figure 1: Photograph of Stephen Selego and Tristan Gingerich with a backpack electrofishing unit and holding bucket, taken at the downstream reference stretch, August 2010. 


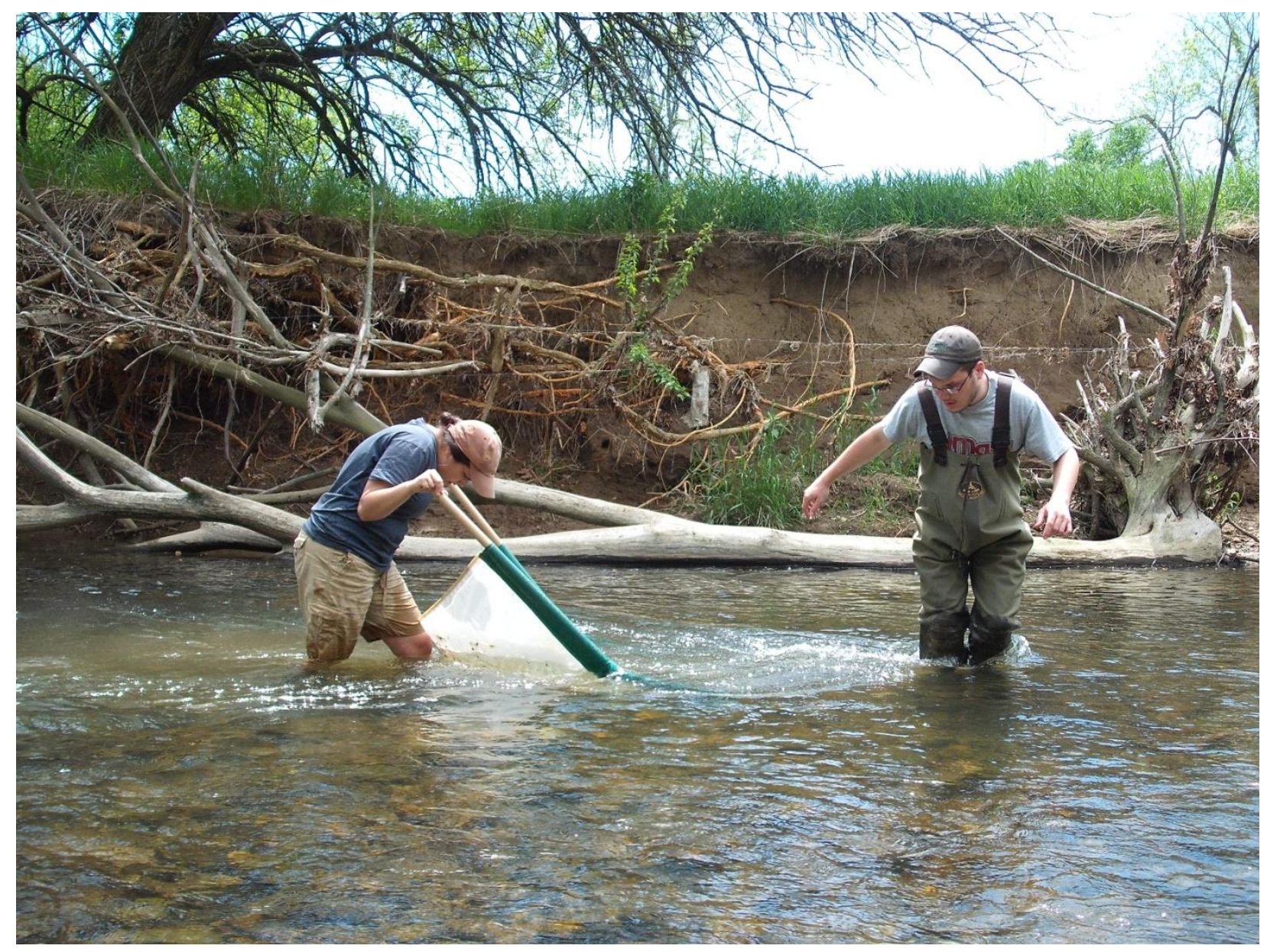

Figure 2: Photograph of Charneé Lee Rose and Jon Holmes performing a kick sample using a hand screen to collect aquatic macroinvertebrates at the upstream control stretch, May 2010. 


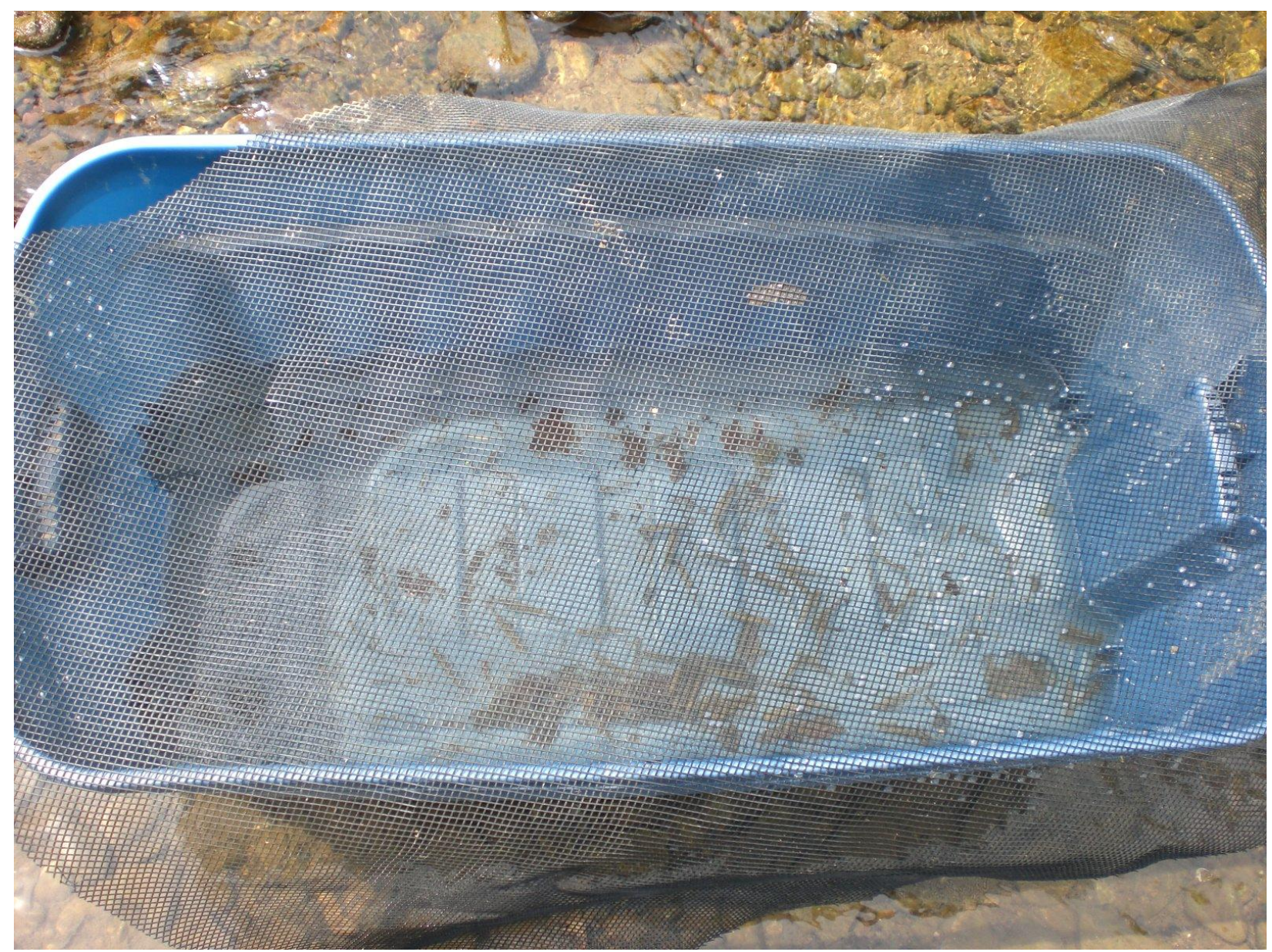

Figure 3: Photograph of one of the large fish-holding bins spaced evenly through the sampling stretch, August 2010. 


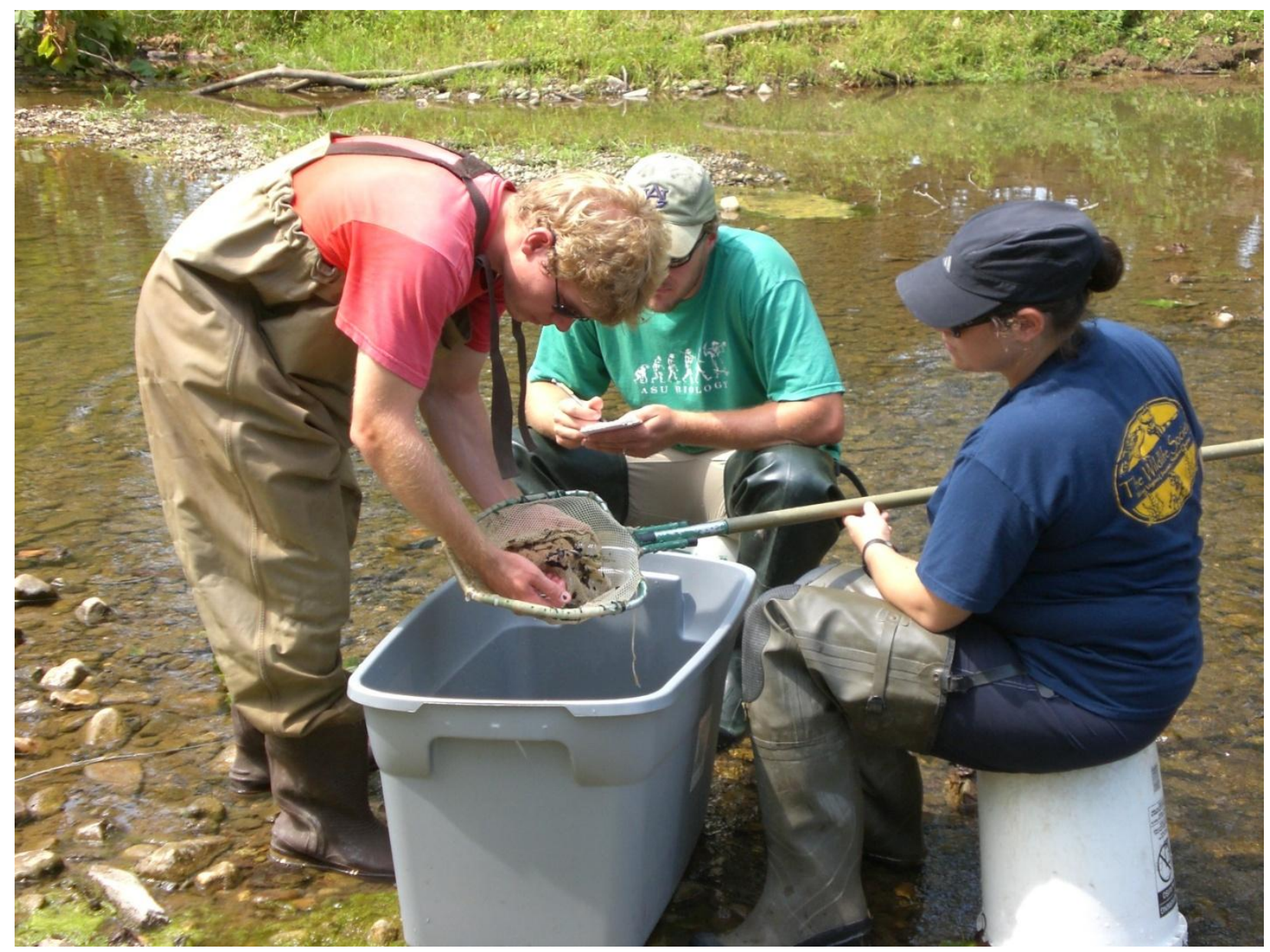

Figure 4: Photograph of Stephen Selego, Jonathan Pitchford, and Crissa Cooey identifying a fish sample at the downstream reference stretch, August 2010. 


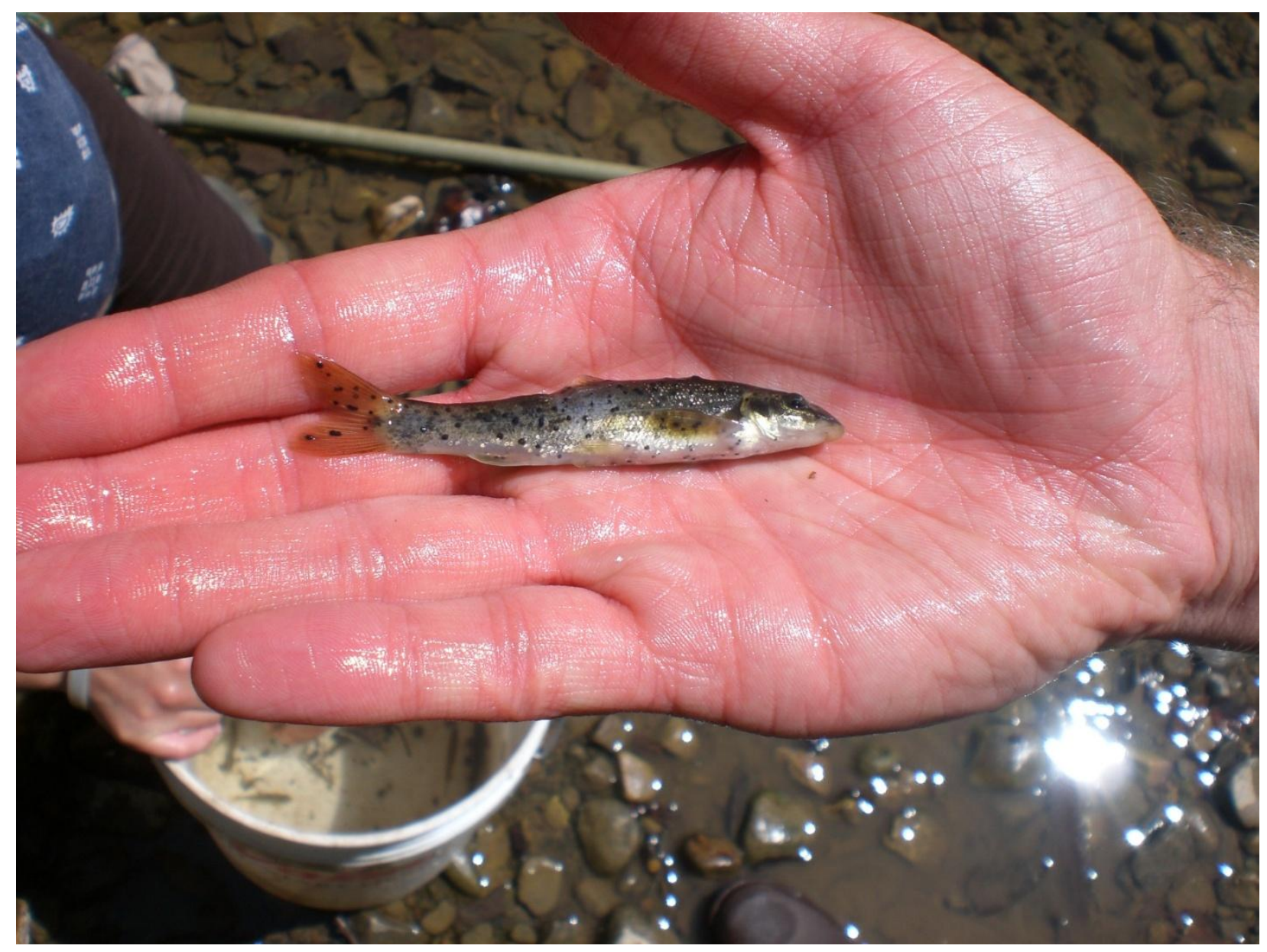

Figure 5: Photograph of a longnose dace (Rhinichthys cataractae) with anomalies (Black Spot Disease), collected at the downstream control stretch during the Summer 2010 sampling season, August 2010. 


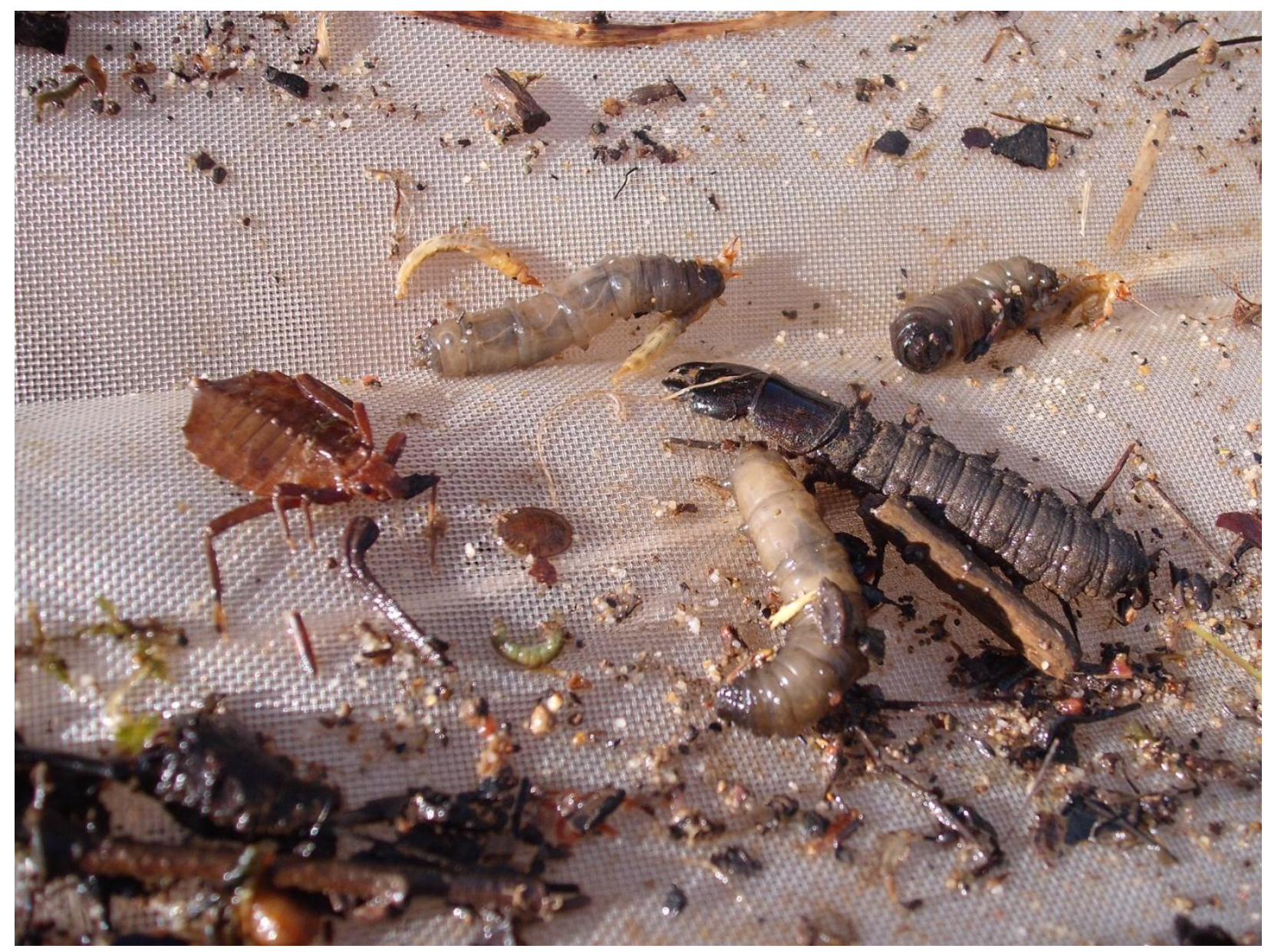

Figure 6: Photograph of a macroinvertebrate sample in a hand screen, collected from the downstream reference stretch during the Winter 2010 sampling season, March 2010. Genera present include Corydalus, Ephemera, Psephenus, Hagenius, and Tipula. 


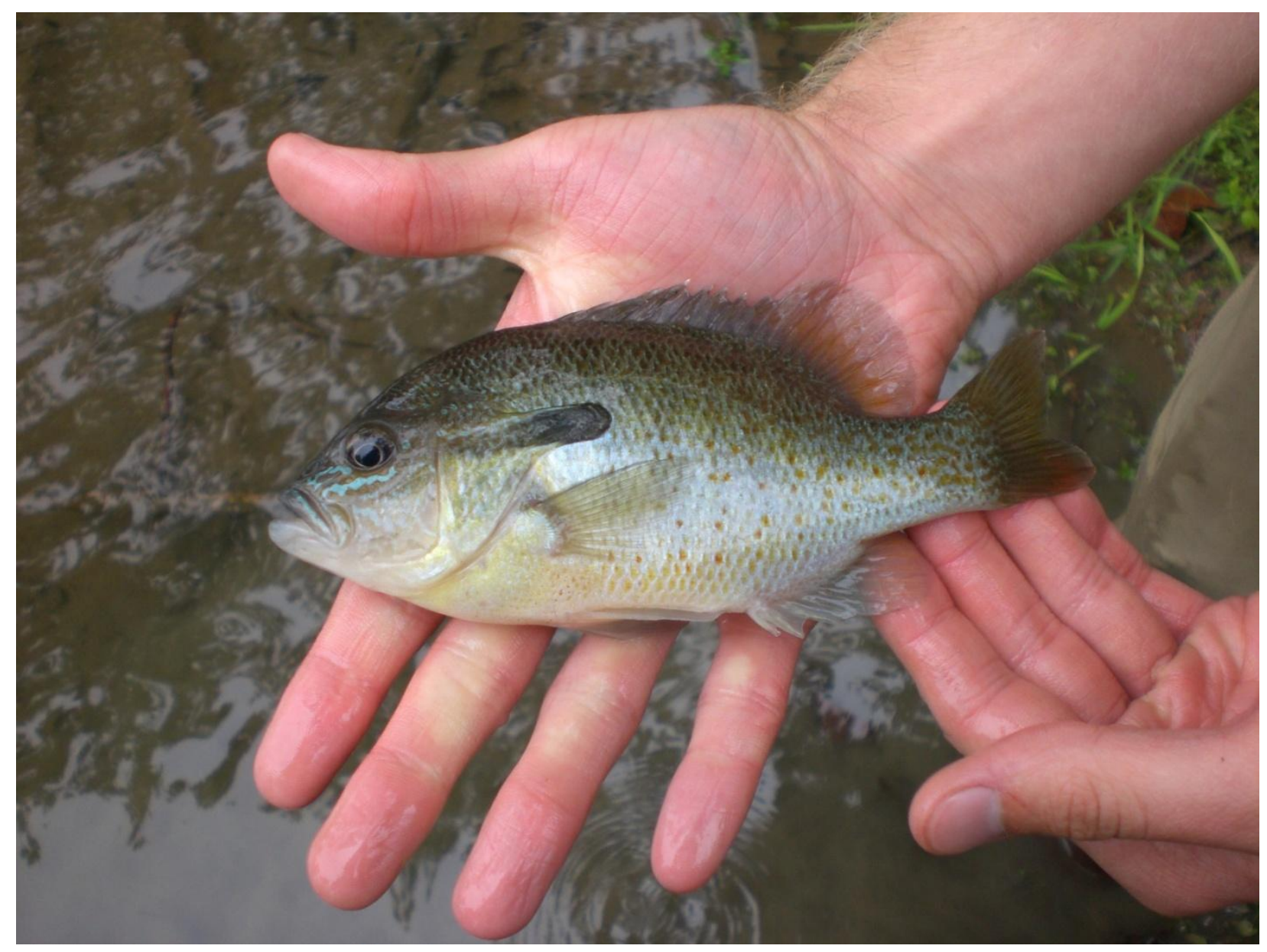

Figure 7: Photograph of a redbreast sunfish (Lepomis auritus), collected during electrofishing, August 2010. Redbreast sunfish were the most abundant centrarchids during electrofishing, but redbreast sunfish nests were found less frequently than longear sunfish (Lepomis megalotis) and rock bass (Ambloplites rupestris) nests. 


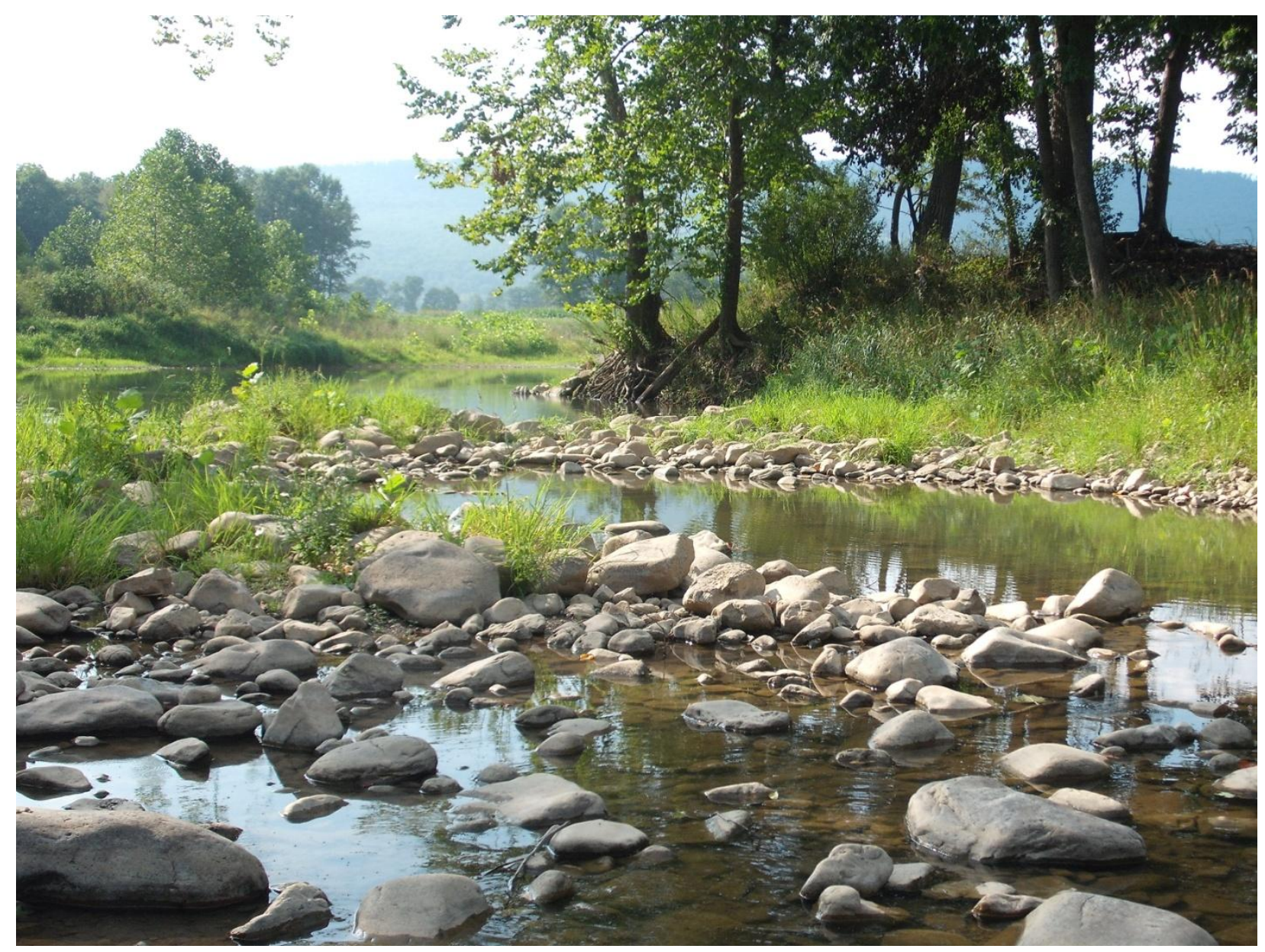

Figure 8: Photograph of a common sunfish nesting area, July 2010. The area is representative of many sites within the Cacapon that support the nesting of multiple species: low water velocity, shallow depth, adequate cover, and gently sloping gravel bank. Of the four species observed nesting in the Cacapon, only smallmouth bass (Micropterus dolomieu) did not nest at this site. 


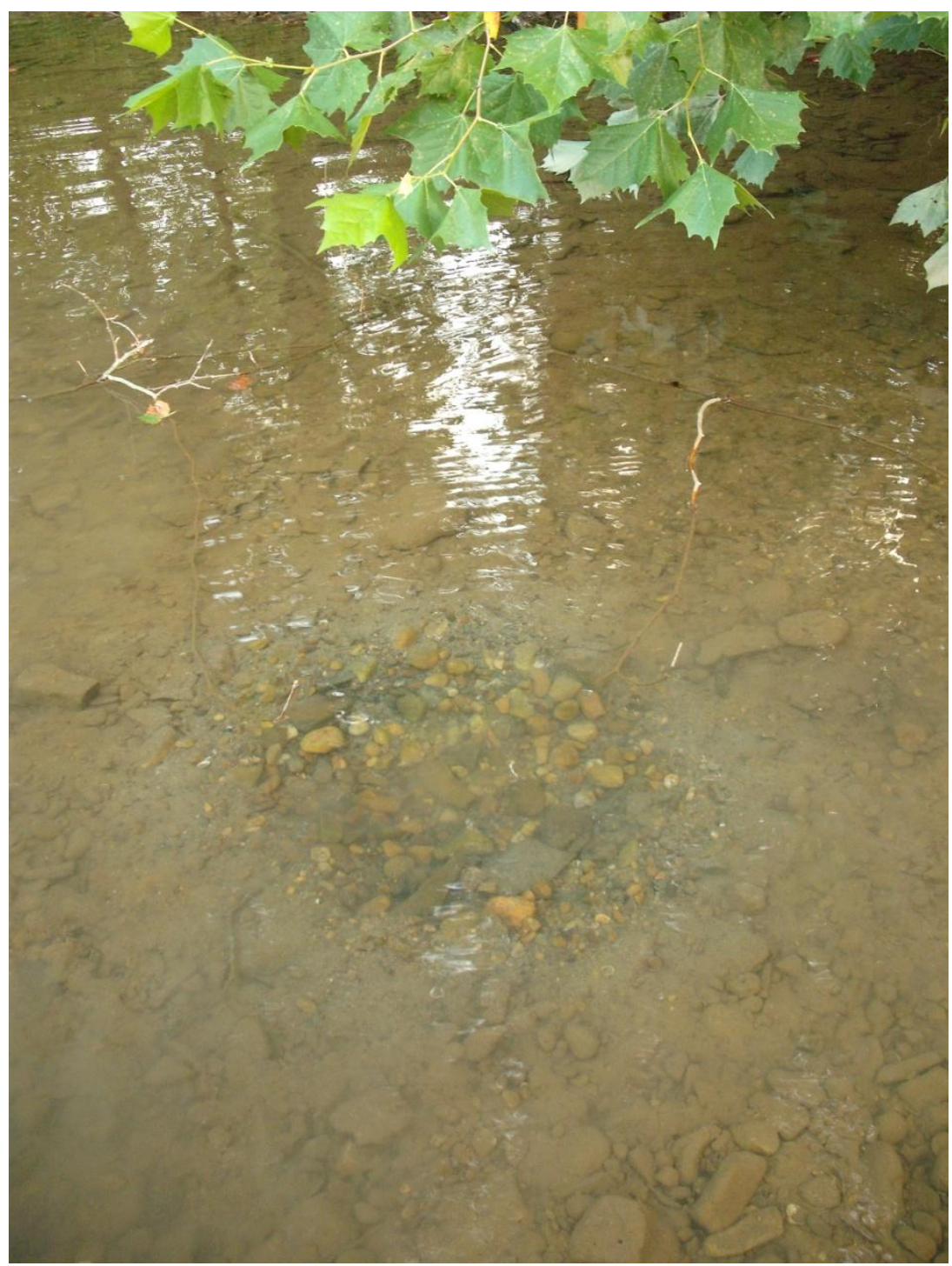

Figure 9: Photograph of an active centrarchid nest, taken close-up to show general lack of fine sediments within the nest (yet abundance of fine sediments surrounding the nest), July 2010. These particles are removed from the nest prior to spawning, to prevent eggs from suffocating. This particular nest belonged to a longear sunfish (Lepomis megalotis), and was located just outside of a large longear sunfish colony. 
Appendix 1a: Example of the data sheet used to select the restoration stretch of the Cacapon River. The criteria and rankings were modified from Strager et al. (2011).

ADMINISTRATIVE DECISIONS

1-1. Conservation Easement

\begin{tabular}{cl}
\hline Scale & \multicolumn{1}{c}{ Factor } \\
\hline $\mathbf{1 0}$ & The property currently has a conservation easement \\
$\mathbf{5}$ & The property has a proposed conservation easement \\
$\mathbf{0}$ & There is no conservation easement \\
\hline
\end{tabular}

Name
1-2. Practice Acceptability

\begin{tabular}{cl} 
Scale & \multicolumn{1}{c}{ Factor } \\
\hline $\mathbf{1 0}$ & $\begin{array}{l}\text { The landowner is willing to allow all proposed instream and riparian management options } \\
\text { The landowner is willing to allow both proposed instream and riparian management but }\end{array}$ \\
$\mathbf{5}$ & $\begin{array}{l}\text { not all the options } \\
\mathbf{0}\end{array}$ \\
\hline
\end{tabular}

1-3. Economy of Scale

Scale

Factor

Will fixing this landowner's reach tie two relatively intact sections or additional project

10 sites together (Cumulative $=10,000+$ feet)?

Will fixing this landowner's reach tie two relatively intact sections or additional project

7 sites together (Cumulative $=5,000+$ feet)?

Will fixing this landowner's reach tie two relatively intact sections or additional project

5 sites together (Cumulative $=1,000+$ feet)?

Will fixing this landowner's reach tie two relatively intact sections or additional project

3 sites together (Cumulative $=500+$ feet $)$ ?

$0 \quad$ Are the adjoining sections not intact and fixing this reach only results in a 1:1 ratio.

\section{ECOLOGICAL FACTORS}

\section{2-1. Incision}

\begin{tabular}{cl}
\hline Scale & \multicolumn{1}{c}{ Factor } \\
\hline $\mathbf{5}$ & Top of bank height/bankfull height $>2.0$ \\
$\mathbf{4}$ & Top of bank height/bankfull height $=1.76-2.0$ \\
$\mathbf{3}$ & Top of bank height/bankfull height $=1.51-1.75$ \\
$\mathbf{2}$ & Top of bank height/bankfull height $=1.26-1.5$ \\
$\mathbf{1}$ & Top of bank height/bankfull height $=1.01-1.25$ \\
$\mathbf{0}$ & Top of bank height/bankfull height $=1.0$ \\
\hline
\end{tabular}

\section{2-2. Relative Channel Width}

\begin{tabular}{cl}
\hline Scale & Factor \\
\hline $\mathbf{5}$ & Low flow width to toe of bank width $=1$ \\
$\mathbf{4}$ & Low flow width to toe of bank width $=0.99-0.9$ \\
$\mathbf{3}$ & Low flow width to toe of bank width $=0.89-0.8$ \\
$\mathbf{2}$ & Low flow width to toe of bank width $=0.79-0.7$ \\
$\mathbf{1}$ & Low flow width to toe of bank width $=0.69-0.6$ \\
$\mathbf{0}$ & Low flow width to toe of bank width $=0.59-0.5$ \\
\hline
\end{tabular}


Appendix 1a cont.

2-3. Bank Erosion

\begin{tabular}{cl}
\hline Scale & \multicolumn{1}{c}{ Factor } \\
\hline $\mathbf{5}$ & Greater than $80 \%$ of channel banks are eroded or eroding \\
$\mathbf{4}$ & $61-80 \%$ of channel banks are eroded or eroding \\
$\mathbf{3}$ & $41-60 \%$ of channel banks are eroded or eroding \\
$\mathbf{2}$ & $21-40 \%$ of channel banks are eroded or eroding \\
$\mathbf{1}$ & $20 \%$ or less of channel banks are eroded or eroding \\
$\mathbf{0}$ & No erosion present on channel banks \\
\hline
\end{tabular}

2-4. Relative Position of Eroded Bank

\begin{tabular}{cl}
\hline Scale & \multicolumn{1}{c}{ Factor } \\
\hline $\mathbf{5}$ & Mid-channel bar \\
$\mathbf{4}$ & Riffle in bend \\
$\mathbf{3}$ & Debris Blockage or shallow pool at bend \\
$\mathbf{2}$ & Straight Riffle \\
$\mathbf{1}$ & Deep pool at a bend or a straight pool \\
$\mathbf{0}$ & None of these issues \\
\hline
\end{tabular}

2-5. Bank Angle

\begin{tabular}{cll} 
Scale & & Factor \\
\hline $\mathbf{5}$ & $>90$ \\
$\mathbf{4}$ & $80-90$ \\
$\mathbf{3}$ & $70-80$ \\
$\mathbf{2}$ & $60-70$ \\
$\mathbf{0}$ & $<60$ & \\
\hline
\end{tabular}

2-6. Bank Material

\begin{tabular}{cll} 
Scale & & Factor \\
$\mathbf{5}$ & Cobble/gravel & \\
$\mathbf{3}$ & Clay/silt & \\
$\mathbf{1}$ & Bedrock & \\
$\mathbf{0}$ & Sand/silt $<60$ & \\
\hline
\end{tabular}

\section{2-7. Bank Vegetation}

Scale

5 Less than $20 \%$ of banks are vegetated with woody vegetation

$420-39 \%$ of banks are vegetated with woody vegetation

$340-59 \%$ of banks are vegetated with woody vegetation

$260-79 \%$ of banks are vegetated with woody vegetation

$180-99 \%$ of banks are vegetated with woody vegetation

$0 \quad 100 \%$ of banks are vegetated with woody vegetation 
Appendix 1a cont.

2-8. Sediment Deposition

\begin{tabular}{cl}
\hline Scale & \multicolumn{1}{c}{ Factor } \\
\hline $\mathbf{5}$ & Transverse Bars \\
$\mathbf{3}$ & Lateral Bars \\
$\mathbf{1}$ & Point Bars \\
$\mathbf{0}$ & No deposition present on channel bed \\
\hline $\mathbf{2 - 9}$. Potential for Continued Threat of Bank Erosion \\
\hline Scale & \multicolumn{1}{c}{ Factor } \\
\hline $\mathbf{5}$ & Meander cut-off \\
$\mathbf{3}$ & Lateral migration/channel widening \\
$\mathbf{2}$ & Banks eroding to stable bend radius \\
$\mathbf{1}$ & Banks eroding to stable angle of repose \\
$\mathbf{0}$ & No potential for continued bank erosion \\
\hline
\end{tabular}

\section{ENGINEERING DESIGN AND CONSTRUCTION FACTORS}

\section{2-10. Total Reach Length}

\begin{tabular}{cl}
\hline Scale & \multicolumn{1}{c}{ Factor } \\
\hline $\mathbf{5}$ & Greater than 6,000 LF \\
$\mathbf{4}$ & 5000 to $5,900 \mathrm{LF}$ \\
$\mathbf{3}$ & $\mathbf{4}, 000$ to $4,900 \mathrm{LF}$ \\
$\mathbf{2}$ & 3,000 to $3,900 \mathrm{LF}$ \\
$\mathbf{1}$ & 2,000 to $2,900 \mathrm{LF}$ \\
$\mathbf{0}$ & 1,000 to 1,900 LF \\
\hline $\mathbf{2 - 1 1 . ~}$ Construction Access & \multicolumn{1}{c}{ Factor } \\
\hline Scale & \\
\hline $\mathbf{5}$ & Fully accessible by all equipment \\
$\mathbf{4}$ & Partially accessible by all equipment \\
$\mathbf{3}$ & Accessible by small equipment \\
$\mathbf{2}$ & Some construction necessary \\
$\mathbf{1}$ & Access can only be accomplished through major construction \\
$\mathbf{0}$ & Inaccessible \\
\hline $\mathbf{2 - 1 2}$ Constructability \\
\hline Scale & \\
\hline $\mathbf{5}$ & High potential for constructability (working within existing pattern and profile) \\
$\mathbf{4}$ & Some minor problems with construction \\
$\mathbf{3}$ & Constructible with extensive planning \\
$\mathbf{2}$ & Great likelihood of construction difficulties \\
$\mathbf{1}$ & Construction difficult, high risk of failure (major pattern/profile work needed) \\
$\mathbf{0}$ & Not feasible for construction \\
\hline
\end{tabular}


Appendix 1a cont.

2-13. Bed Material To prioritize work in the easiest materials:

\begin{tabular}{|c|c|}
\hline Scale & Factor \\
\hline 5 & Gravel bed material (D50 $=2-64 \mathrm{~mm}$ ) Cobble \\
\hline 4 & Cobble bed material $(\mathrm{D} 50=64-256 \mathrm{~mm}$ ) Gravel \\
\hline 3 & Sand bed material (D50 $=0.062-2 \mathrm{~mm}$ ) Silt/Clay \\
\hline 2 & Silt-Clay bed material $(\mathrm{D} 50<0.062 \mathrm{~mm}$ ) Sand \\
\hline 1 & Boulder bed material (D50 = 256 - $2048 \mathrm{~mm}$ ) \\
\hline 0 & Bedrock bed material (D50 > $2048 \mathrm{~mm}$ ) \\
\hline \multicolumn{2}{|c|}{ 2-14. Construction Intrusion Into Adjacent Habitat } \\
\hline Scale & Factor \\
\hline 1 & No functional wetlands adjacent to the site \\
\hline 0 & Functional wetlands present adjacent to site \\
\hline \multicolumn{2}{|c|}{$\begin{array}{l}\text { ANTHROPOGENIC FACTORS } \\
\text { 2-15. Educational Value }\end{array}$} \\
\hline Scale & Factor \\
\hline 5 & High potential for educational benefit \\
\hline 3 & Moderate potential for educational benefit \\
\hline 0 & Low potential for educational benefit \\
\hline
\end{tabular}

2-16. Recreational Value and potential for in-stream habitat improvement (bed form diversity, woody debris, etc)?

\begin{tabular}{cl}
\hline Scale & \multicolumn{1}{c}{ Factor } \\
\hline $\mathbf{5}$ & High potential for recreational benefit \\
$\mathbf{3}$ & Moderate potential for recreational benefit \\
$\mathbf{0}$ & Low potential for recreational benefit \\
\hline $\mathbf{2 - 1 7 .}$ Archaeological Resource Potential Based on Landowner or Local Knowledge \\
\hline Scale & \multicolumn{1}{c}{ Factor } \\
\hline $\mathbf{5}$ & Confirmed absence of significant archaeological site \\
$\mathbf{3}$ & Probable absence of archeological site \\
$\mathbf{1}$ & Probable presence of archaeological site \\
$\mathbf{0}$ & Confirmed presence of archaeological site \\
\hline
\end{tabular}


Appendix Ib: Rapid visual habitat assessment (RVHA) scores, following Barbour et al. (1999), for the five Cacapon restoration project sampling stretches, taken Summer 2009 (pre-restoration) and Summer 2010 (post-restoration).

\begin{tabular}{cccccccc}
\hline Survey & Site & Epif/cover & Embed & Vel/dpth & Sed dep & Flow stat & Chan alt \\
\hline Pre & UC & 13 & 16 & 16 & 16 & 12 & 17 \\
Pre & UR & 14 & 14 & 15 & 15 & 14 & 17 \\
Pre & Rest & 12 & 15 & 18 & 17 & 14 & 17 \\
Pre & DC & 16 & 13 & 12 & 16 & 13 & 17 \\
Pre & DR & 14 & 16 & 14 & 18 & 19 & 17 \\
Survey & Site & Freq rif & Bank stab & Bank veg & Rip width & Sum & \\
\hline Pre & UC & 13 & 13 & 10 & 13 & 139 & \\
Pre & UR & 13 & 17 & 17 & 16 & 152 & \\
Pre & Rest & 13 & 9 & 13 & 8 & 136 & \\
Pre & DC & 13 & 13 & 14 & 9 & 136 & \\
Pre & DR & 13 & 16 & 18 & 18 & 163 & \\
Survey & Site & Epif/cover & Embed & Vel/dpth & Sed dep & Flow stat & Chan alt \\
\hline Post & UC & 12 & 15 & 15 & 17 & 11 & 17 \\
Post & UR & 15 & 14 & 14 & 17 & 15 & 17 \\
Post & Rest & 13 & 9 & 18 & 10 & 14 & 17 \\
Post & DC & 14 & 11 & 12 & 15 & 13 & 17 \\
Post & DR & 17 & 14 & 15 & 16 & 14 & 17 \\
Survey & Site & Freq rif & Bank stab & Bank veg & Rip width & Sum & \\
\hline Post & UC & 13 & 11 & 12 & 13 & 136 & \\
Post & UR & 13 & 16 & 19 & 15 & 155 & \\
Post & Rest & 13 & 17 & 15 & 15 & 141 & \\
Post & DC & 13 & 12 & 15 & 8 & 130 & \\
Post & DR & 13 & 15 & 18 & 18 & 157 & \\
\hline
\end{tabular}


Appendix IIb: List of aquatic macroinvertebrates collected from all sampling stretches in the Cacapon River with associated functional feeding groups (Mandaville 2002).

\begin{tabular}{|c|c|c|c|c|c|c|c|}
\hline Taxon & Genera & FFG & Total & Taxon & Genera & FFG & Total \\
\hline Aeshnidae & 1 & PR & 2 & Lepidostomatidae & 1 & $\mathrm{SH}$ & 1 \\
\hline Amphipoda & 1 & CG & 51 & Leptoceridae & 1 & PR & 21 \\
\hline Ancylidae & 2 & $\mathrm{SC}$ & 56 & Leptohyphidae & 1 & CG & 116 \\
\hline Athericidae & 1 & PR & 217 & Leptophlebiidae & 1 & CG & 19 \\
\hline Baetidae & 3 & CG & 2272 & Lestidae & 2 & PR & 4 \\
\hline Baetiscidae & 1 & CG & 4 & Leuctridae & 3 & $\mathrm{SH}$ & 145 \\
\hline Blephariceridae & 1 & $\mathrm{SC}$ & 5 & Limnephilidae & 4 & $\mathrm{SH}$ & 34 \\
\hline Brachycentridae & 3 & $\mathrm{SH}, \mathrm{CF}$ & 78 & Lymnaeidae & 1 & CG & 72 \\
\hline Caenidae & 1 & $\mathrm{CG}$ & 428 & Molannidae & 1 & $\mathrm{SC}$ & 1 \\
\hline Cambaridae & 2 & CG & 12 & Nemouridae & 2 & $\mathrm{SH}$ & 61 \\
\hline Capniidae & 3 & $\mathrm{SH}$ & 253 & Odontoceridae & 1 & $\mathrm{SC}$ & 1 \\
\hline Chaoboridae & 1 & PR & 1 & Oligochaeta & 1 & CG & 116 \\
\hline Chironomidae & 4 & CG & 3293 & Perlidae & 6 & PR & 115 \\
\hline Coenagrionidae & 3 & PR & 117 & Perlodidae & 4 & PR & 38 \\
\hline Corbiculidae & 1 & $\mathrm{CF}$ & 376 & Philopotamidae & 2 & $\mathrm{CF}$ & 1389 \\
\hline Corydalidae & 3 & PR & 702 & Physidae & 1 & CG & 8 \\
\hline Dryopidae & 1 & $\mathrm{SC}$ & 22 & Planorbidae & 1 & $\mathrm{SC}$ & 2 \\
\hline Elmidae & 3 & $\mathrm{SC}$ & 4417 & Pleuroceridae & 1 & $\mathrm{SC}$ & 673 \\
\hline Empididae & 1 & PR & 64 & Polycentropodidae & 1 & PR & 22 \\
\hline Ephemerellidae & 6 & $\mathrm{CG}, \mathrm{SC}$ & 2710 & Polymitarcyidae & 1 & CG & 17 \\
\hline Ephemeridae & 2 & $\mathrm{CG}$ & 17 & Potamanthidae & 1 & CG & 228 \\
\hline Gerridae & 1 & PR & 12 & Psephenidae & 2 & $\mathrm{SC}$ & 2095 \\
\hline Gomphidae & 4 & PR & 78 & Pteronarcyidae & 1 & $\mathrm{SH}$ & 17 \\
\hline Gyrinidae & 2 & PR & 52 & Pyralidae & 1 & $\mathrm{SC}$ & 2 \\
\hline Haliplidae & 1 & $\mathrm{SH}$ & 1 & Rhyacophilidae & 1 & PR & 14 \\
\hline Heptageniidae & 2 & $\mathrm{SC}$ & 2374 & Sialidae & 1 & PR & 36 \\
\hline Hirudinea & 1 & PR & 12 & Simuliidae & 1 & $\mathrm{CF}$ & 2065 \\
\hline Hydroarachnidia & 1 & PR & 1 & Sphaeriidae & 1 & $\mathrm{CF}$ & 90 \\
\hline Hydropsychidae & 2 & $\mathrm{CF}$ & 2509 & Tabanidae & 1 & CG & 1 \\
\hline Hydrophilidae & 1 & CG & 2 & Taeniopterygidae & 2 & $\mathrm{SH}$ & 27 \\
\hline Hydroptilidae & 1 & $\mathrm{SC}$ & 31 & Tipulidae & 2 & $\mathrm{SH}, \mathrm{CG}$ & 114 \\
\hline Isonychiidae & 1 & $\mathrm{CF}$ & 2420 & Uenoidae & 1 & $\mathrm{SC}$ & 351 \\
\hline Isopoda & 1 & CG & 2 & Veliidae & 1 & $\mathrm{PR}$ & 2 \\
\hline
\end{tabular}

$\mathrm{CG}=$ Collector-gatherer

$\mathrm{CF}=$ Collector-filterer

$\mathrm{PR}=$ Predator

$\mathrm{SC}=$ Scraper

$\mathrm{SH}=$ Shredder 
Appendix IIIb: Aquatic macroinvertebrate metric 'total taxa', with scores across all sampling stretches and sampling seasons. Upstream control (impaired stretch, but not receiving restoration) denoted ' $\mathrm{UC}$ ', downstream control denoted 'DC', upstream reference (unimpaired, natural stretch) denoted ' $U R$ ', and downstream reference denoted 'DR'. The restoration stretch is denoted as 'Rest'.

\section{Total Taxa}

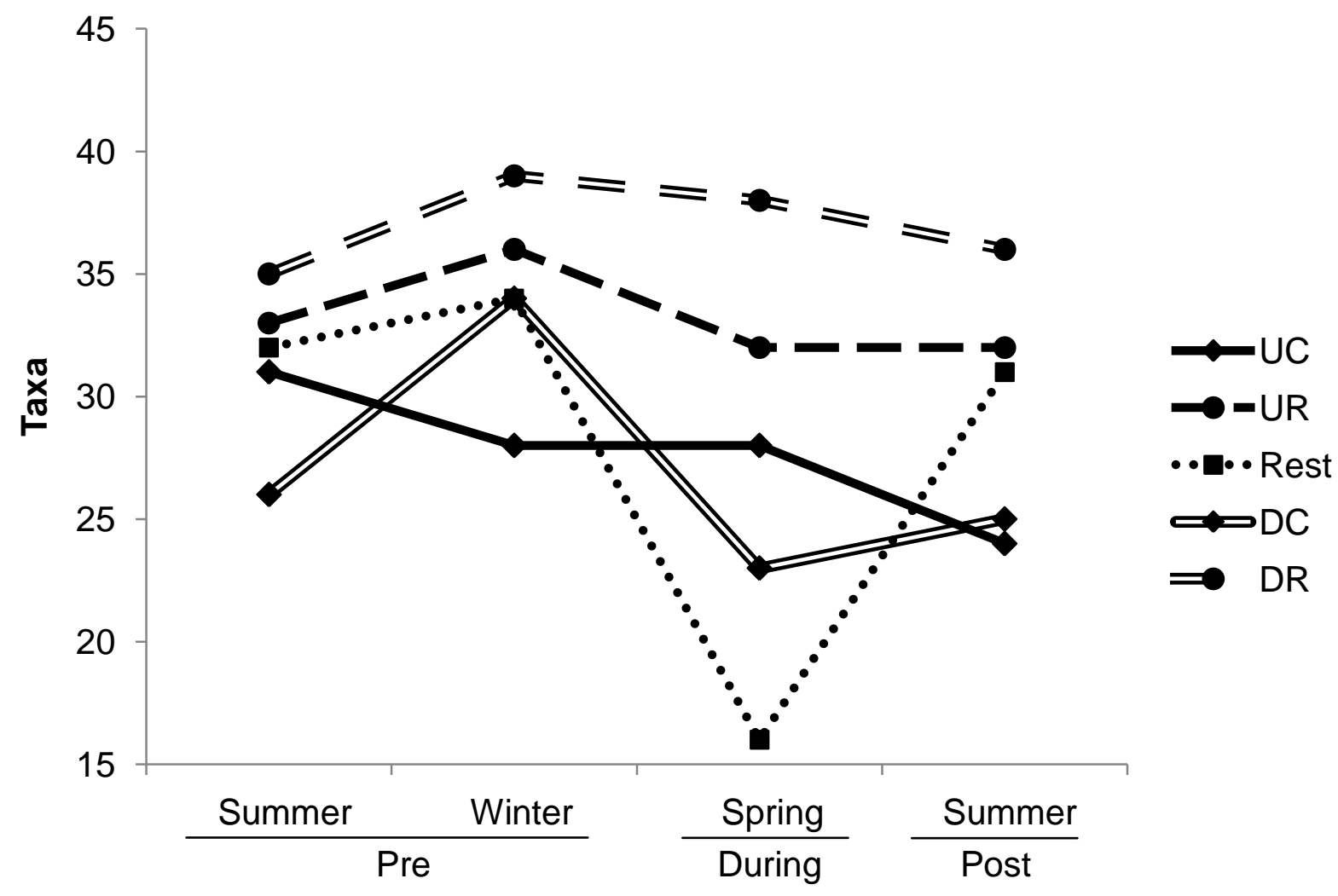


Appendix IVb: Aquatic macroinvertebrate metric 'total genera', with scores across all sampling stretches and sampling seasons. Upstream control (impaired stretch, but not receiving restoration) denoted 'UC', downstream control denoted 'DC', upstream reference (unimpaired, natural stretch) denoted 'UR', and downstream reference denoted 'DR'. The restoration stretch is denoted as 'Rest'.

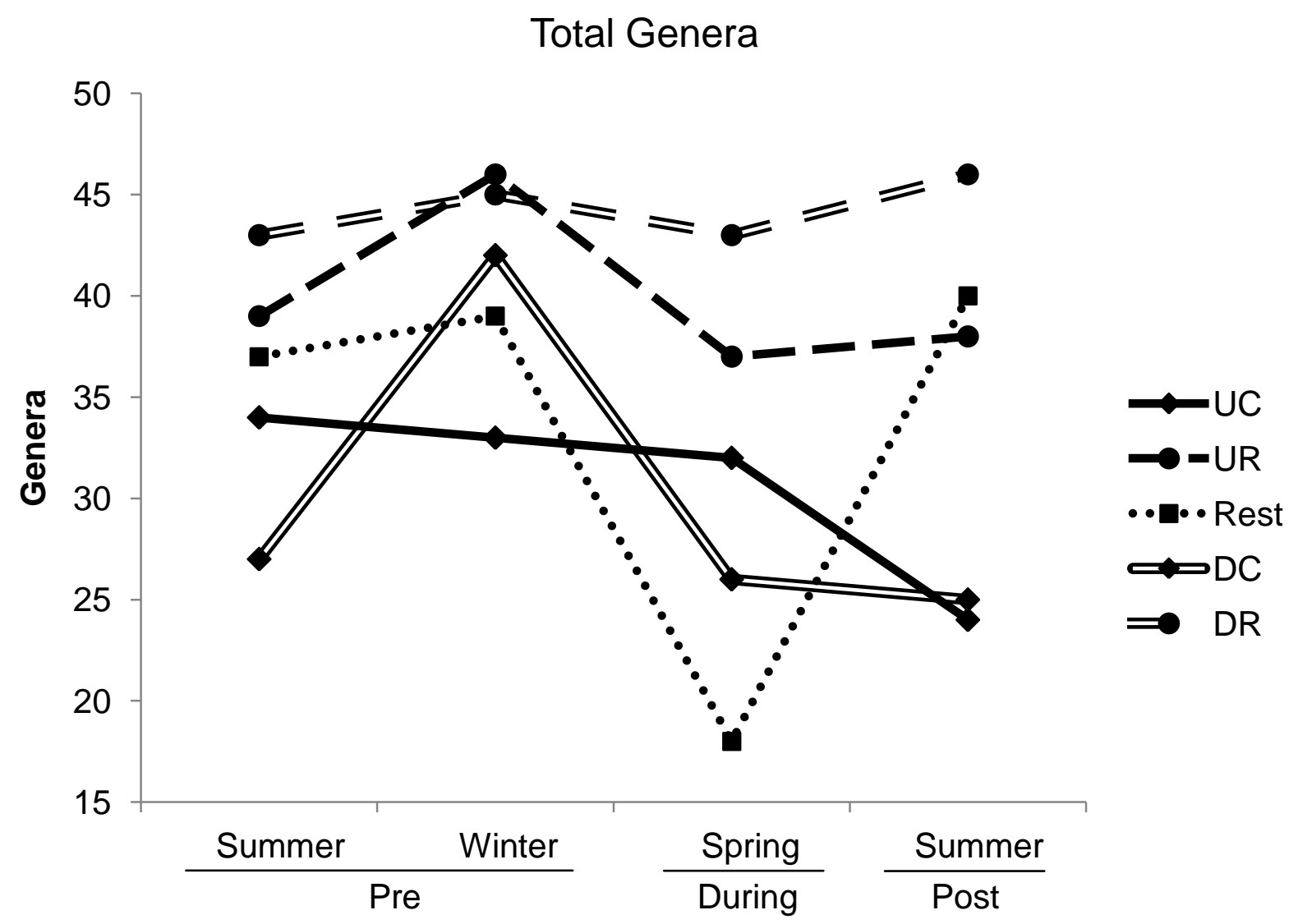


Appendix Vb: Aquatic macroinvertebrate metric 'total Ephemeroptera, Plecoptera, and Trichoptera (EPT) taxa', with scores across all sampling stretches and sampling seasons. Upstream control (impaired stretch, but not receiving restoration) denoted 'UC', downstream control denoted 'DC', upstream reference (unimpaired, natural stretch) denoted 'UR', and downstream reference denoted 'DR'. The restoration stretch is denoted as 'Rest'.

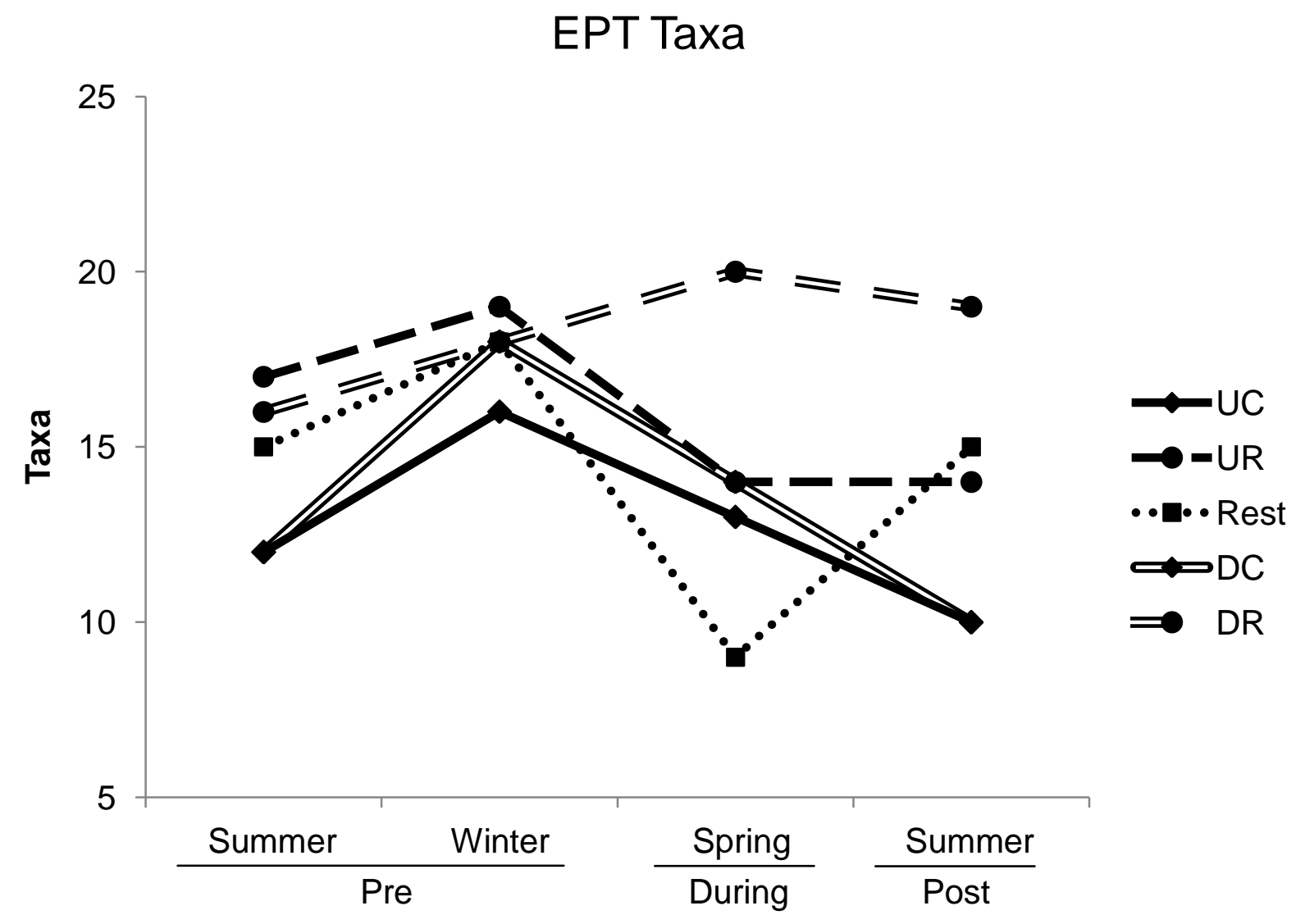


Appendix VIb: Aquatic macroinvertebrate metric 'percent Ephemeroptera, Plecoptera, and Trichoptera (EPT)', with scores across all sampling stretches and sampling seasons. Upstream control (impaired stretch, but not receiving restoration) denoted ' $U C$ ', downstream control denoted 'DC', upstream reference (unimpaired, natural stretch) denoted 'UR', and downstream reference denoted 'DR'. The restoration stretch is denoted as 'Rest'.

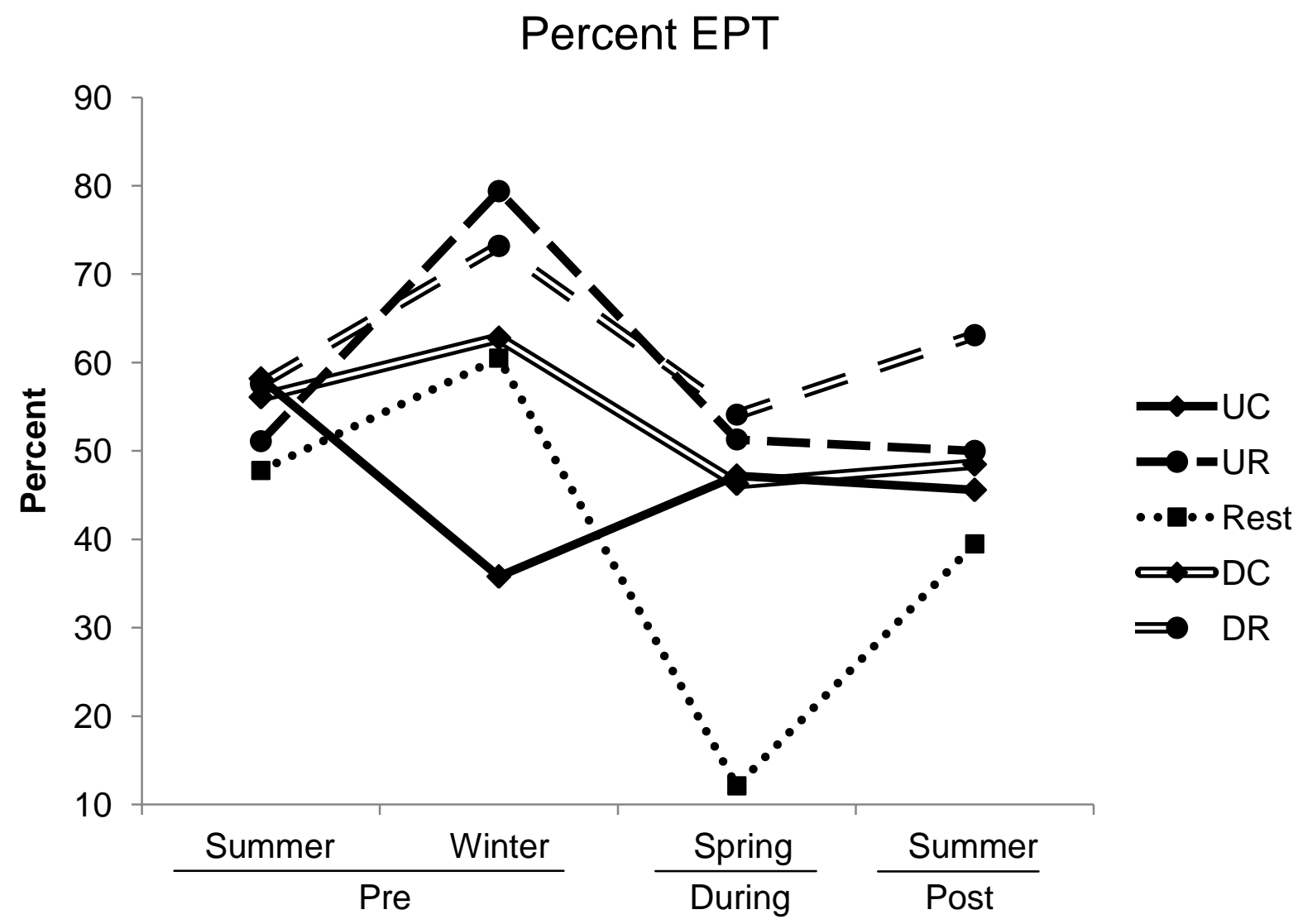


Appendix VIIb: Aquatic macroinvertebrate metric 'percent Chironomidae', with scores across all sampling stretches and sampling seasons. Upstream control (impaired stretch, but not receiving restoration) denoted ' $\mathrm{UC}$ ', downstream control denoted 'DC', upstream reference (unimpaired, natural stretch) denoted 'UR', and downstream reference denoted 'DR'. The restoration stretch is denoted as 'Rest'.

\section{Percent Chironomidae}

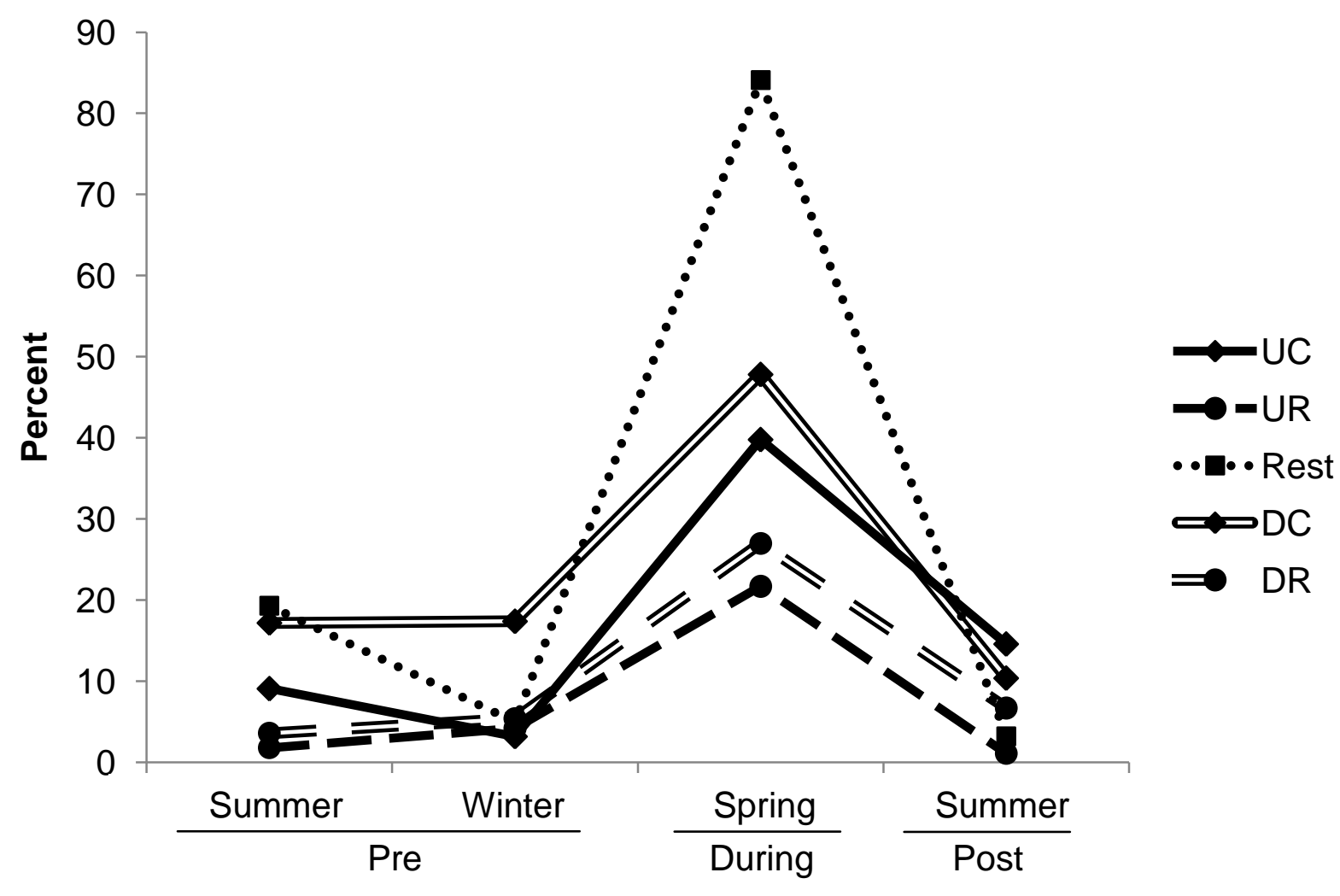


Appendix VIIIb: Aquatic macroinvertebrate metric 'percent dominant two taxa', with scores across all sampling stretches and sampling seasons. Upstream control (impaired stretch, but not receiving restoration) denoted ' $U C$ ', downstream control denoted ' $D C$ ', upstream reference (unimpaired, natural stretch) denoted 'UR', and downstream reference denoted 'DR'. The restoration stretch is denoted as 'Rest'.

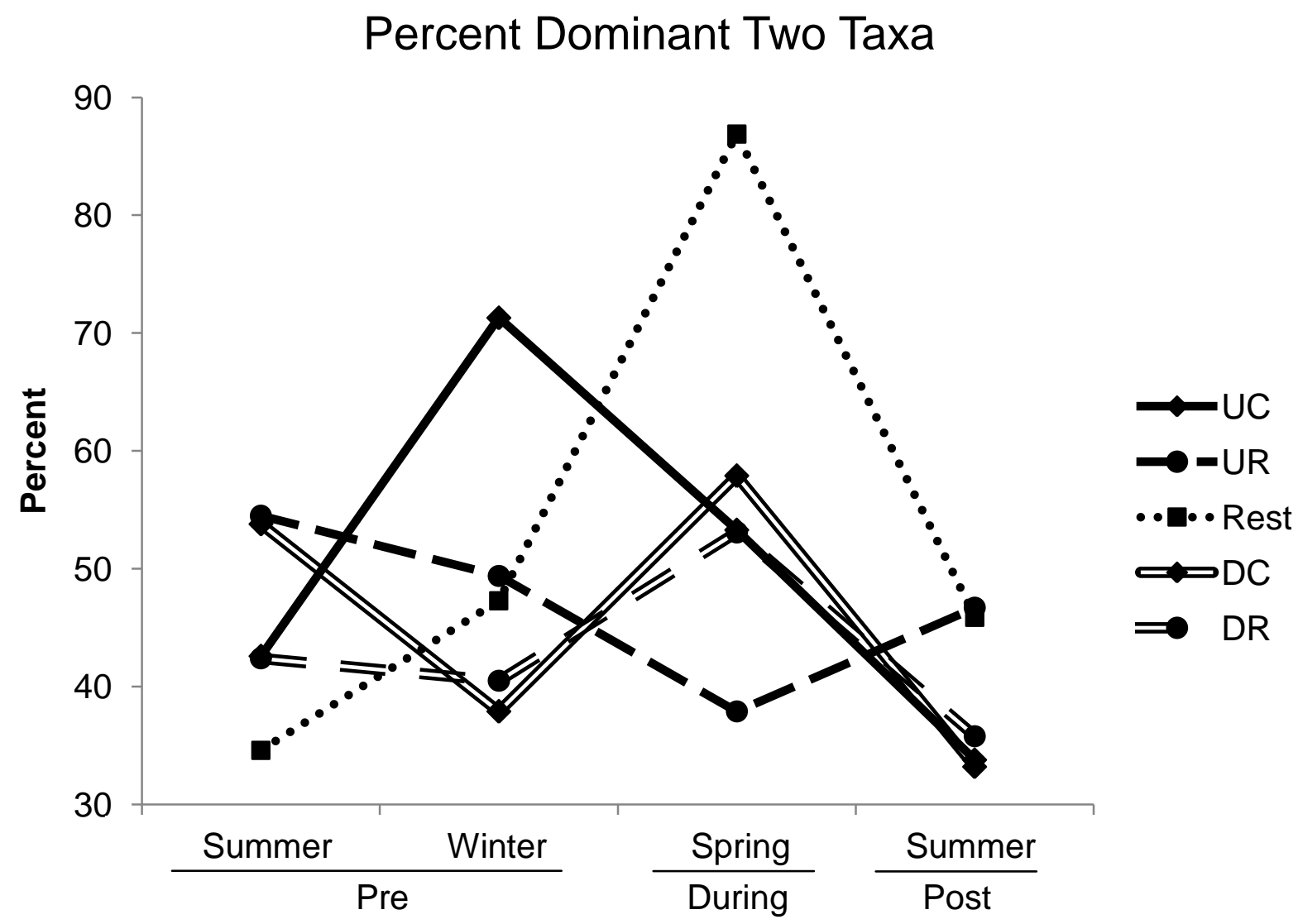


Appendix IXb: Aquatic macroinvertebrate metric 'Hilsenhoff Biotic Index score', with scores across all sampling stretches and sampling seasons. Upstream control (impaired stretch, but not receiving restoration) denoted ' $U C$ ', downstream control denoted ' $D C$ ', upstream reference (unimpaired, natural stretch) denoted 'UR', and downstream reference denoted 'DR'. The restoration stretch is denoted as 'Rest'.

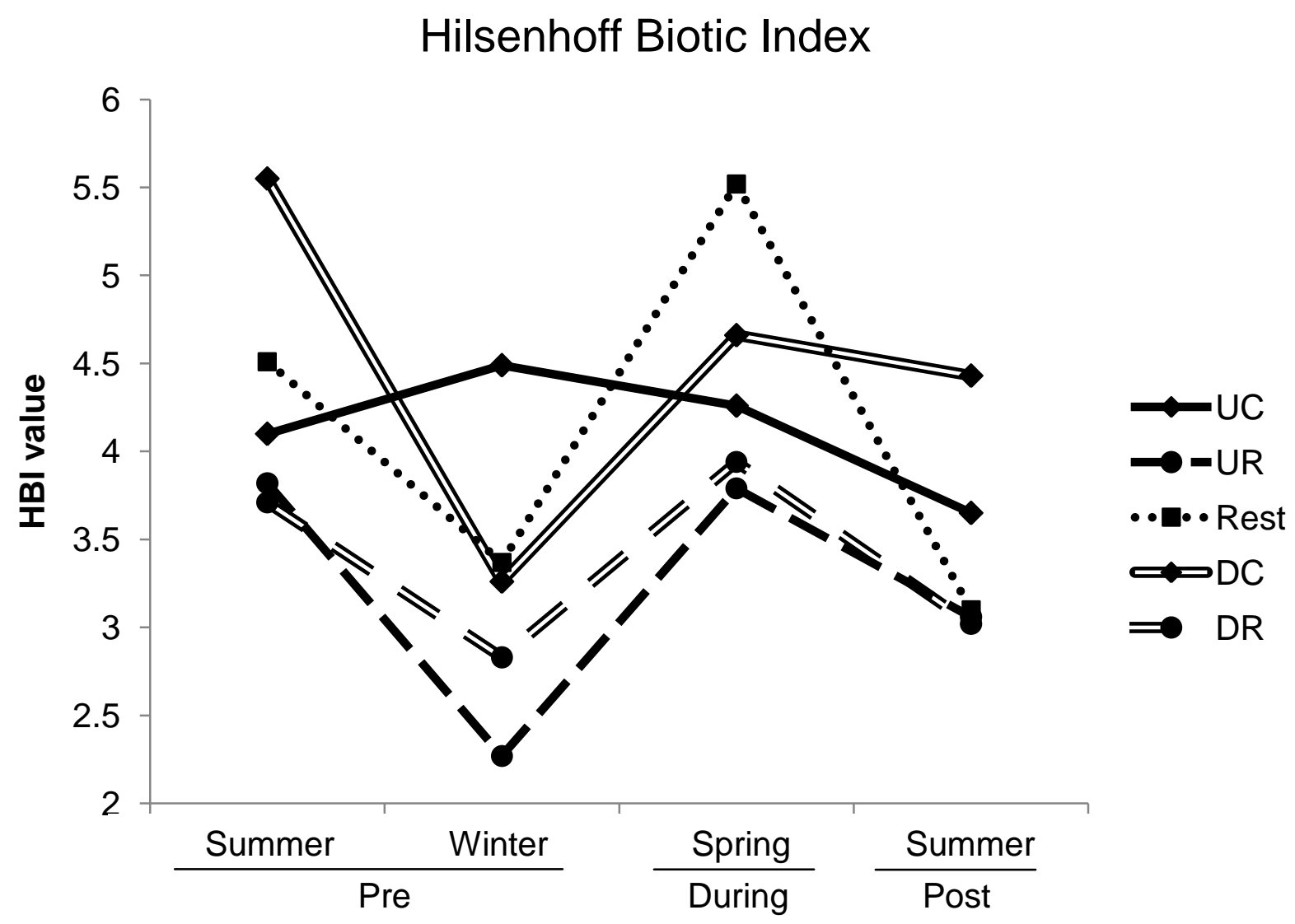


Appendix Xb: Aquatic macroinvertebrate metric 'total abundance', with scores across all sampling stretches and sampling seasons. Upstream control (impaired stretch, but not receiving restoration) denoted ' $U C$ ', downstream control denoted 'DC', upstream reference (unimpaired, natural stretch) denoted 'UR', and downstream reference denoted 'DR'. The restoration stretch is denoted as 'Rest'.

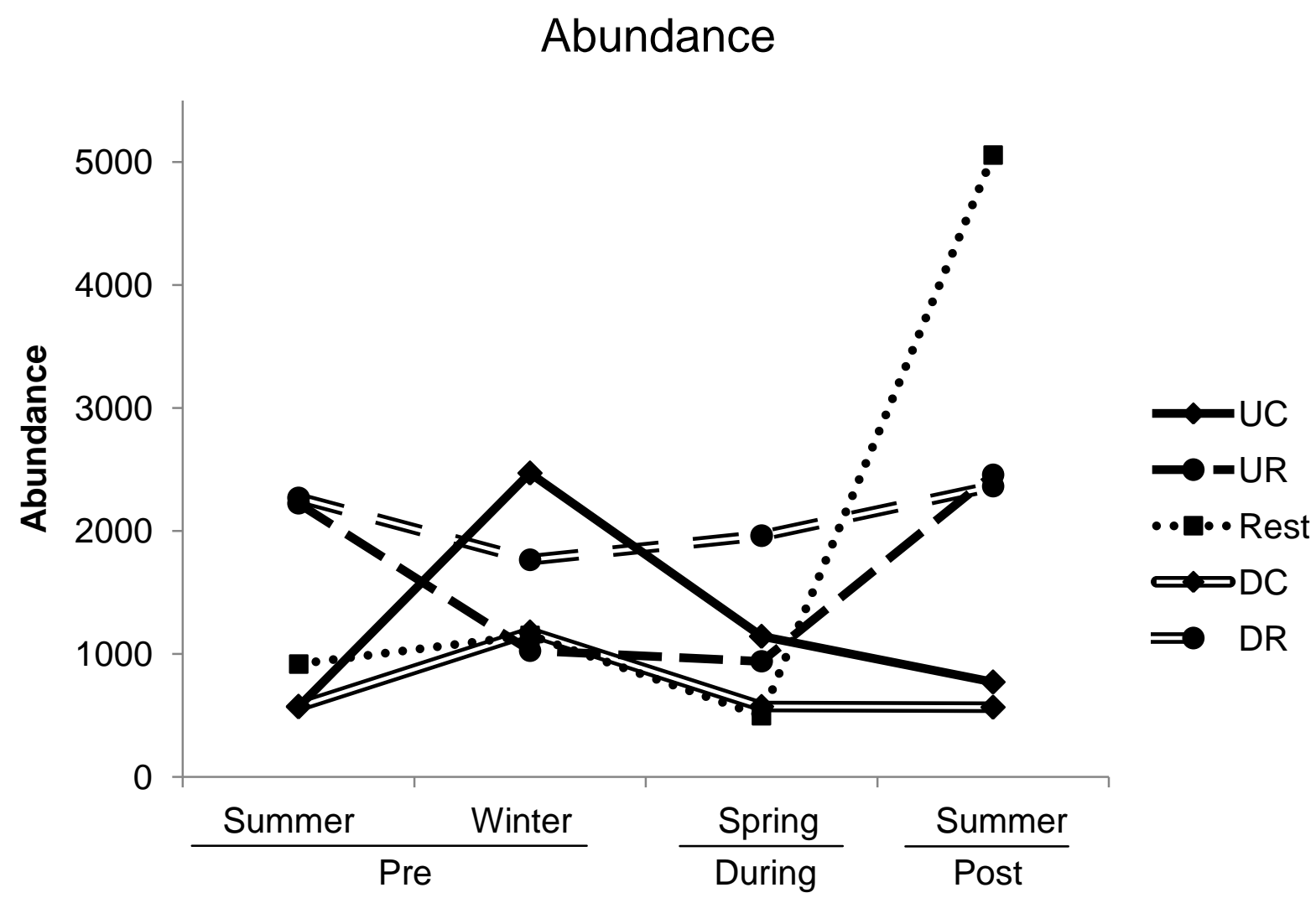


Appendix XIb: Functional feeding group proportions present at each stretch during each sampling season. Upstream control (impaired stretch, but not receiving restoration) denoted ' $U C$ ', downstream control denoted 'DC', upstream reference (unimpaired, natural stretch) denoted 'UR', and downstream reference denoted 'DR'. The restoration stretch is denoted as 'Re'. 'Post' refers to postrestoration samples, 'Dur' refers to during restoration samples, and 'Pre' refers to pre-restoration samples from summer 2009 (S) and winter $2010(\mathrm{~W})$.

\section{Functional feeding group proportions}

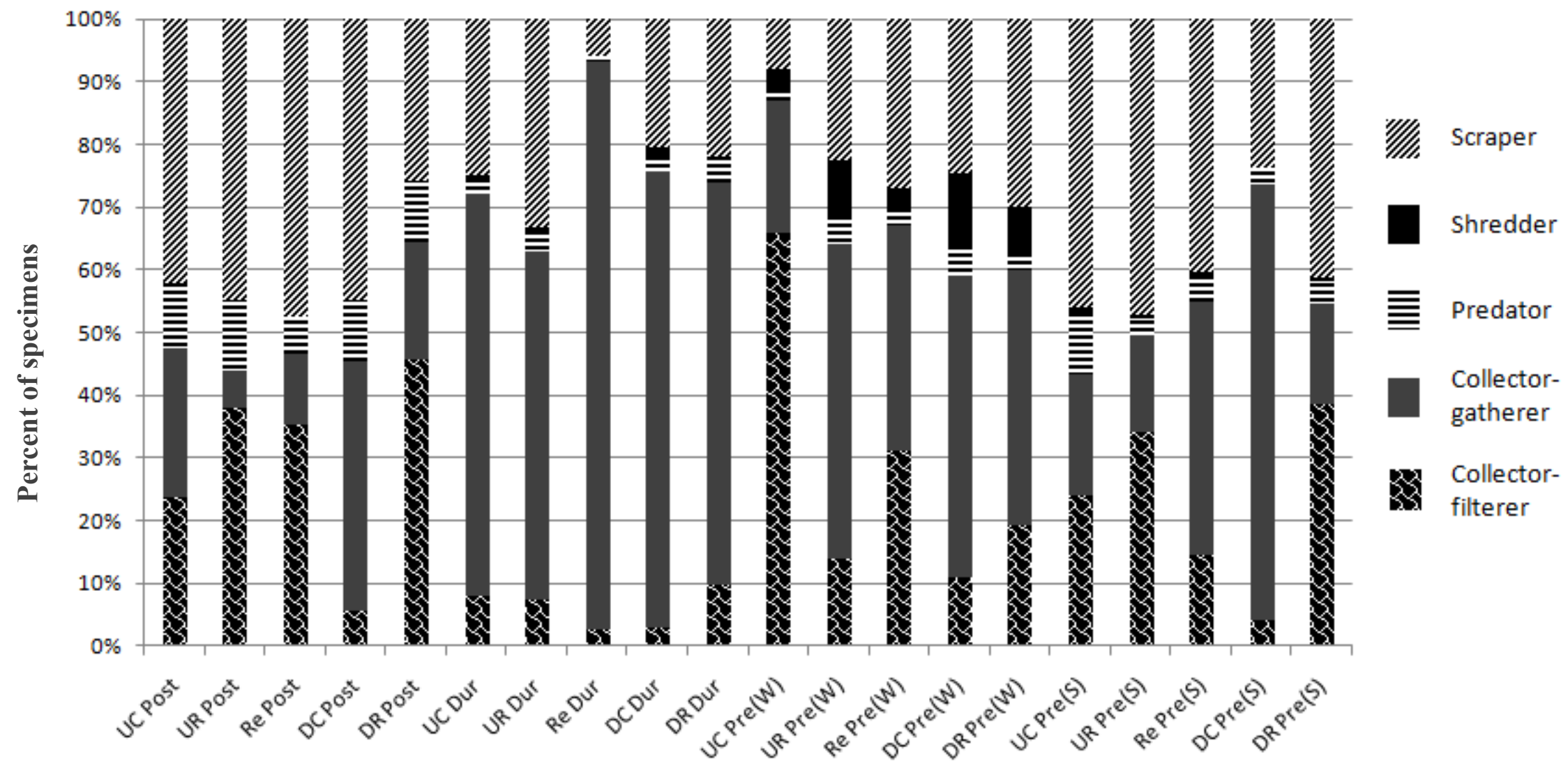


Appendix XIIb: List of fish species collected during electrofishing in the Cacapon River at all sampling stretches, 2009-2010.

\begin{tabular}{|c|c|c|c|c|}
\hline Family & Common name & Scientific name & Total & Locations \\
\hline Catostomidae & White sucker & Catostomus commersoni & 49 & All \\
\hline Catostomidae & Northern hogsucker & Hypentelium nigricans & 41 & All \\
\hline Catostomidae & Golden redhorse & Moxostoma erythrurum & 9 & $\mathrm{UC}, \mathrm{DC}, \mathrm{DR}$ \\
\hline Catostomidae & Shorthead redhorse & Moxostoma macrolepidotum & 3 & DR \\
\hline Centrarchidae & Rock bass & Ambloplites rupestris & 43 & All \\
\hline Centrarchidae & Redbreast sunfish & Lepomis auritus & 241 & All \\
\hline Centrarchidae & Green sunfish & Lepomis cyanellus & 5 & DC \\
\hline Centrarchidae & Pumpkinseed & Lepomis gibbosus & 6 & UR, DC, DR \\
\hline Centrarchidae & Bluegill & Lepomis macrochirus & 11 & $\mathrm{UR}, \mathrm{Re}, \mathrm{DC}, \mathrm{DR}$ \\
\hline Centrarchidae & Longear sunfish & Lepomis megalotis & 4 & $\mathrm{UR}, \mathrm{Re}, \mathrm{DC}$ \\
\hline Centrarchidae & Smallmouth bass & Micropterus dolomieu & 22 & All \\
\hline Centrarchidae & Largemouth bass & Micropterus salmoides & 3 & DC \\
\hline Cottidae & Blue ridge sculpin & Cottus caeruleomentum & 110 & All \\
\hline Cottidae & Potomac sculpin & Cottus girardi & 32 & $\mathrm{UC}, \mathrm{UR}, \mathrm{Re}, \mathrm{DR}$ \\
\hline Cyprinidae & Central stoneroller & Campostoma anomalum & 48 & UC, UR, Re, DR \\
\hline Cyprinidae & Spotfin shiner & Cyprinella spiloptera & 20 & UC, UR, Re, DC \\
\hline Cyprinidae & Cutlips minnow & Exoglossum maxillingua & 7 & UR, Re, DR \\
\hline Cyprinidae & Common shiner & Luxilus cornutus & 3 & $\mathrm{Re}, \mathrm{DR}$ \\
\hline Cyprinidae & River chub & Nocomis micropogon & 2 & $\mathrm{UC}, \mathrm{UR}$ \\
\hline Cyprinidae & Comely shiner & Notropis amoenus & 33 & $\mathrm{UC}, \mathrm{RF}$ \\
\hline Cyprinidae & Silverjaw minnow & Notropis buccatus & 2 & DR \\
\hline Cyprinidae & Rosyface shiner & Notropis rubellus & 186 & All \\
\hline Cyprinidae & Mimic shiner & Notropis volucellus & 18 & UR, Re, DR \\
\hline Cyprinidae & Bluntnose minnow & Pimephales notatus & 934 & All \\
\hline Cyprinidae & Blacknose dace & Rhinichthys atratulus & 21 & $\mathrm{UC}, \mathrm{UR}, \mathrm{Re}, \mathrm{DR}$ \\
\hline Cyprinidae & Longnose dace & Rhinichthys cataractae & 35 & $\mathrm{UC}, \mathrm{UR}, \mathrm{Re}, \mathrm{DR}$ \\
\hline Cyprinidae & Creek chub & Semotilus atromaculatus & 48 & UR, Re, DC, DR \\
\hline Cyprinidae & Fallfish & Semotilus corporalis & 77 & All \\
\hline Ictaluridae & Yellow bullhead & Ameiurus natalis & 24 & $\mathrm{UR}, \mathrm{Re}, \mathrm{DC}, \mathrm{DR}$ \\
\hline Ictaluridae & Margined madtom & Noturus insignis & 8 & All \\
\hline Percidae & Greenside darter & Etheostoma blennoides & 22 & All \\
\hline Percidae & Fantail darter & Etheostoma flabellare & 63 & All \\
\hline Percidae & Tessellated darter & Etheostoma olmstedi & 175 & All \\
\hline \multicolumn{2}{|c|}{$\mathrm{UC}=$ upstream control } & $\mathrm{DC}=$ downstream control & & \\
\hline \multicolumn{2}{|c|}{$\mathrm{UR}=$ upstream reference } & $\mathrm{DR}=$ downstream reference & & \\
\hline \multicolumn{2}{|l|}{$\mathrm{Re}=$ restoration } & All $=$ all five stretches & & \\
\hline
\end{tabular}


Appendix XIIIb: Bar graph of fish species collected during electrofishing in the Cacapon River at all sampling stretches across all sampling seasons, 2009-2010.

\section{Overall Species Abundance}

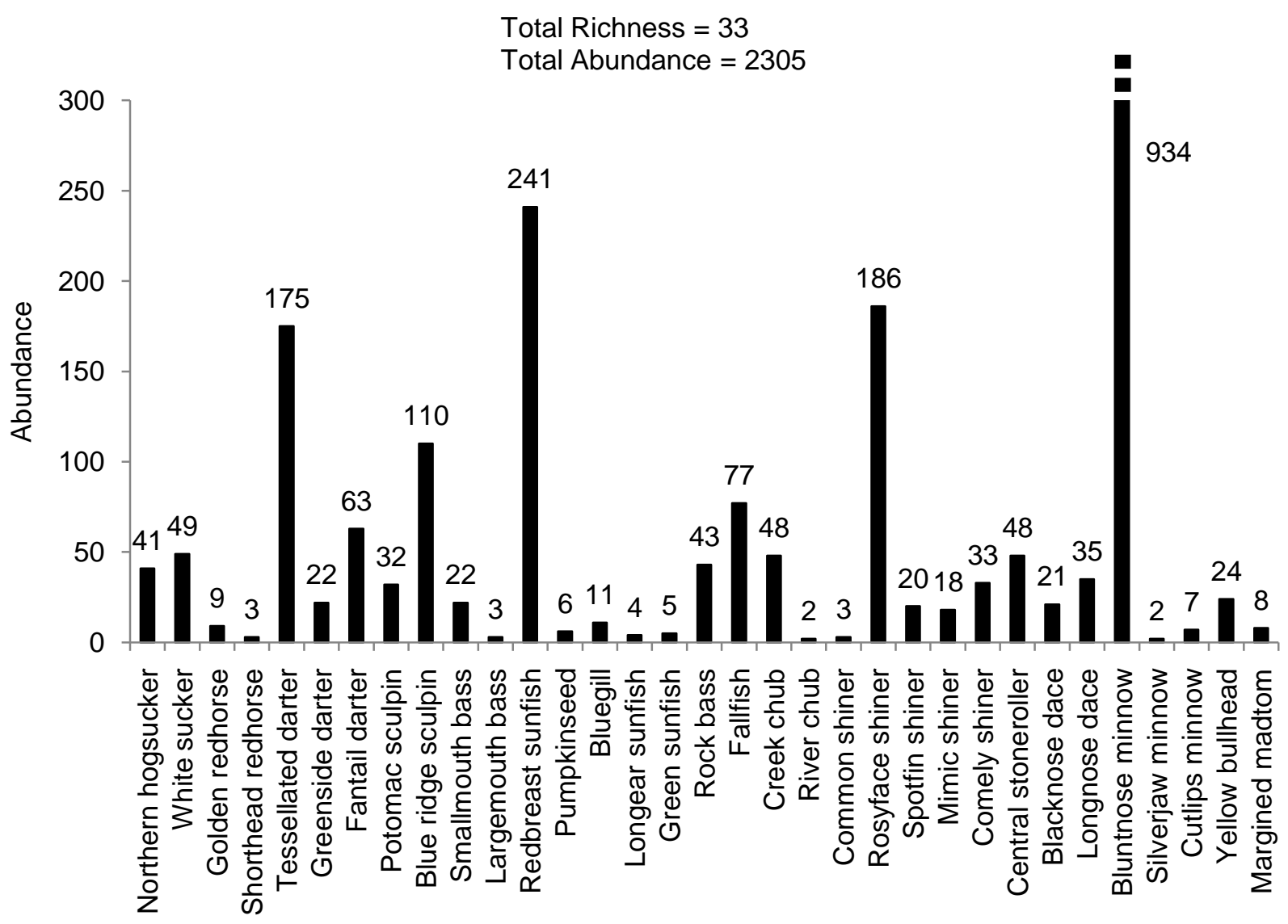


Appendix XIVb: Bar graph of centrarchid species collected during electrofishing in the Cacapon River at all sampling stretches across all sampling seasons, 2009-2010.

\section{Overall Centrarchid Abundance}

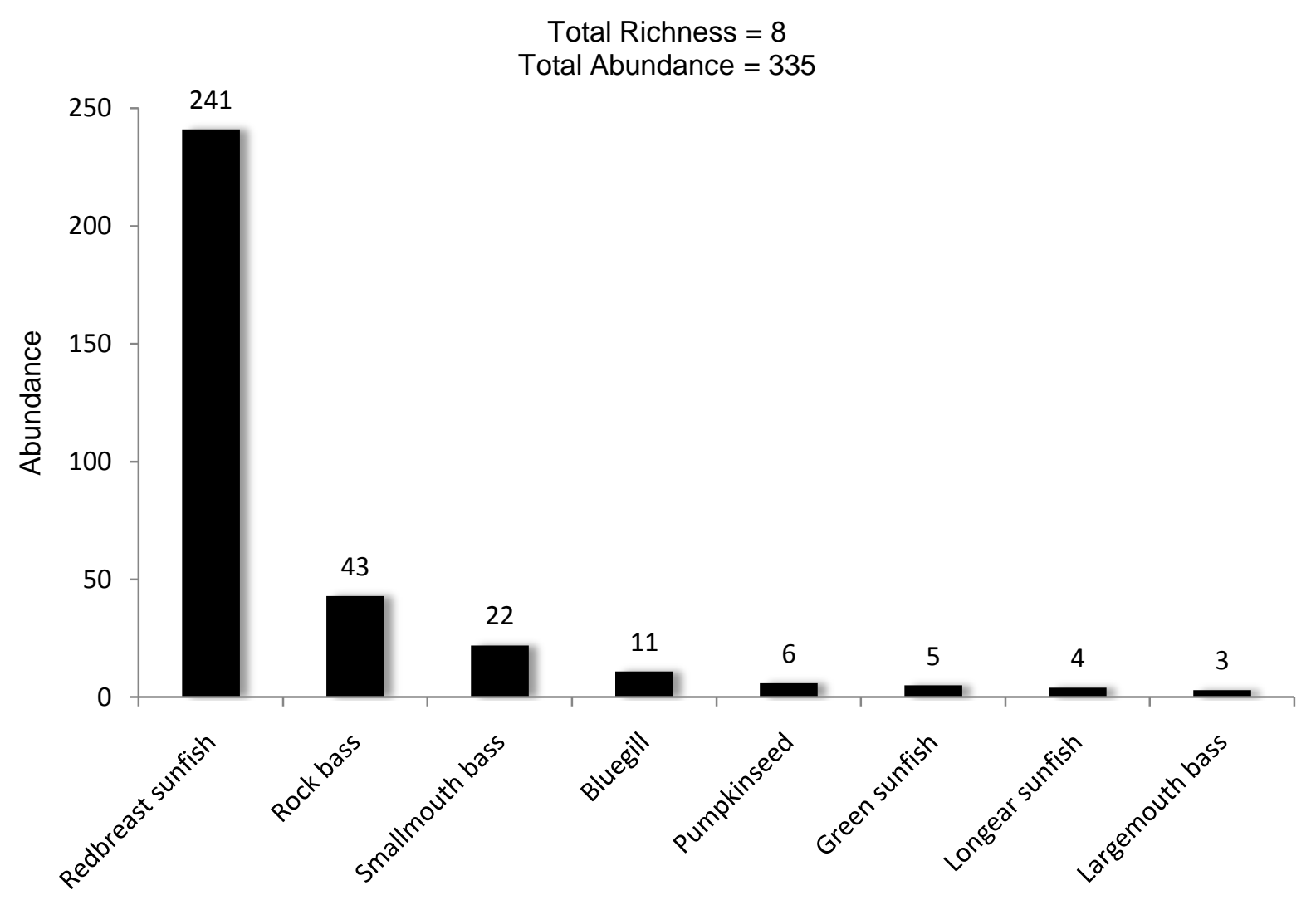


Appendix XVb: Daniels et al. (2002) index of biotic integrity (IBI) metric scores at each sampling stretch during each sampling season. Upstream control (impaired stretch, but not receiving restoration) denoted ' $U C$ ', downstream control denoted ' $D C$ ', upstream reference (unimpaired, natural stretch) denoted 'UR', and downstream reference denoted 'DR'. The restoration stretch is denoted as 'Rest'.

\begin{tabular}{|c|c|c|c|c|c|c|c|}
\hline Sample & IBI & Metric & $\mathbf{U C}$ & UR & Rest & DR & DC \\
\hline \multirow[t]{13}{*}{ Pre-rest } & Daniels & Total species & 3 & 5 & 5 & 5 & 5 \\
\hline & & Total benthic insectivorous & 5 & 5 & 5 & 5 & 3 \\
\hline & & Total water column & 3 & 5 & 5 & 5 & 5 \\
\hline & & Total terete minnow & 3 & 5 & 3 & 5 & 3 \\
\hline & & $\%$ dominant & 5 & 5 & 5 & 5 & 5 \\
\hline & & $\%$ Catostomus & 5 & 5 & 5 & 5 & 5 \\
\hline & & $\%$ generalist & 5 & 3 & 3 & 3 & 3 \\
\hline & & $\%$ insectivores & 5 & 5 & 5 & 5 & 1 \\
\hline & & $\%$ top carnivore & 1 & 3 & 1 & 3 & 5 \\
\hline & & Total individuals & 3 & 5 & 5 & 5 & 5 \\
\hline & & $\%$ multiple size classes & 1 & 3 & 3 & 3 & 3 \\
\hline & & $\%$ with anomalies & 1 & 1 & 1 & 3 & 1 \\
\hline & & Total & 40 & 50 & 46 & 52 & 44 \\
\hline
\end{tabular}

\begin{tabular}{|c|c|c|c|c|c|c|c|}
\hline Sample & IBI & Metric & $\mathbf{U C}$ & UR & Rest & DR & DC \\
\hline \multirow[t]{13}{*}{ During } & Daniels & Total species & 3 & & 1 & & 3 \\
\hline & & Total benthic insectivorous & 3 & & 1 & & 1 \\
\hline & & Total water column & 3 & & 1 & & 3 \\
\hline & & Total terete minnow & 3 & & 3 & & 3 \\
\hline & & $\%$ dominant & 5 & & 1 & & 5 \\
\hline & & $\%$ Catostomus & 5 & & 3 & & 5 \\
\hline & & $\%$ generalist & 3 & & 1 & & 3 \\
\hline & & $\%$ insectivores & 5 & & 1 & & 5 \\
\hline & & $\%$ top carnivore & 3 & & 3 & & 5 \\
\hline & & Total individuals & 3 & & 1 & & 1 \\
\hline & & $\%$ with multiple size classes & 3 & & 5 & & 3 \\
\hline & & $\%$ with anomalies & 5 & & 5 & & 1 \\
\hline & & Total & 44 & & 26 & & 38 \\
\hline
\end{tabular}


Appendix XVb cont.

\begin{tabular}{|c|c|c|c|c|c|c|c|}
\hline Sample & IBI & Metric & $\mathbf{U C}$ & UR & Rest & DR & DC \\
\hline \multirow[t]{13}{*}{ Post-rest } & \multirow[t]{13}{*}{ Daniels } & Total species & 3 & 5 & 5 & 5 & 1 \\
\hline & & Total benthic insectivorous & 3 & 3 & 5 & 5 & 3 \\
\hline & & Total water column & 1 & 3 & 3 & 3 & 5 \\
\hline & & Total terete minnow & 3 & 5 & 3 & 5 & 1 \\
\hline & & $\%$ dominant & 5 & 5 & 1 & 5 & 1 \\
\hline & & $\%$ Catostomus & 5 & 3 & 5 & 5 & 5 \\
\hline & & $\%$ generalist & 3 & 3 & 1 & 3 & 1 \\
\hline & & $\%$ insectivores & 3 & 3 & 3 & 3 & 3 \\
\hline & & $\%$ top carnivore & 5 & 5 & 3 & 1 & 5 \\
\hline & & Total individuals & 1 & 3 & 5 & 5 & 3 \\
\hline & & $\%$ multiple size classes & 3 & 5 & 5 & 5 & 3 \\
\hline & & $\%$ with anomalies & 1 & 1 & 1 & 3 & 1 \\
\hline & & Total & 36 & 44 & 40 & 48 & 32 \\
\hline
\end{tabular}


Appendix XVIb: McCormick et al. (2001) index of biotic integrity (IBI) metric scores at each sampling stretch during each sampling season. Upstream control (impaired stretch, but not receiving restoration) denoted ' $U C$ ', downstream control denoted ' $D C$ ', upstream reference (unimpaired, natural stretch) denoted 'UR', and downstream reference denoted 'DR'. The restoration stretch is denoted as 'Rest'.

\begin{tabular}{lllccccc}
\hline Sample & IBI & Metric & UC & UR & Rest & DR & DC \\
\hline Pre-rest & McCormick & Total non-tol cyprinid & 9 & 10 & 7 & 9 & 0 \\
& & Total benthic & 10 & 10 & 10 & 10 & 10 \\
& Total sensitive & 7 & 3 & 9 & 4 & 0 \\
& \% Cottidae & 6 & 10 & 6 & 10 & 6 \\
& \% tolerant & 8 & 6 & 7 & 8 & 7 \\
& \% Non-natives & 10 & 10 & 10 & 9 & 9 \\
& \% pisc or pisc/inv & 10 & 10 & 10 & 8 & 10 \\
& \% macro-omnivore & 10 & 8 & 9 & 8 & 9 \\
& \% gravel spawners & 3 & 4 & 0 & 8 & 1 \\
& Total & 73 & 71 & 68 & 74 & 52 \\
\hline
\end{tabular}

\begin{tabular}{|c|c|c|c|c|c|c|c|}
\hline Sample & IBI & Metric & UC & UR & Rest & DR & DC \\
\hline \multirow[t]{10}{*}{ During } & McCormick & Total non-tol cyprinid & 2 & & 0 & & 0 \\
\hline & & Total benthic & 9 & & 0 & & 0 \\
\hline & & Total sensitive & 0 & & 2 & & 0 \\
\hline & & $\%$ Cottidae & 6 & & 0 & & 0 \\
\hline & & $\%$ tolerant & 4 & & 2 & & 5 \\
\hline & & $\%$ Non-natives & 2 & & 2 & & 8 \\
\hline & & $\%$ pisc or pisc/inv & 2 & & 2 & & 9 \\
\hline & & $\%$ macro-omnivore & 10 & & 0 & & 9 \\
\hline & & $\%$ gravel spawners & 10 & & 10 & & 0 \\
\hline & & Total & 45 & & 18 & & 31 \\
\hline
\end{tabular}


Appendix XVIb cont.

\begin{tabular}{lllccccc}
\hline Sample & IBI & Metric & UC & UR & Rest & DR & DC \\
\hline \multirow{2}{*}{ Post-rest } & McCormick & Total non-tol cyprinid & 0 & 9 & 5 & 7 & 0 \\
& & Total benthic & 10 & 10 & 10 & 10 & 8 \\
& & 6 & 10 & 10 & 10 & 0 \\
& Total sensitive & 7 & 2 & 1 & 1 & 0 \\
& \% Cottidae & 9 & 6 & 3 & 6 & 4 \\
& \% tolerant & 10 & 10 & 10 & 10 & 10 \\
& \% Non-natives & 10 & 10 & 10 & 10 & 10 \\
& \% pisc or pisc/inv & 9 & 2 & 9 & 7 & 8 \\
& \% macro-omnivore & 10 & 6 & 0 & 2 & 0 \\
& \% gravel spawners & 71 & 65 & 58 & 63 & 40 \\
\hline
\end{tabular}


Appendix XVIIb: Pearson's correlation coefficients and associated permutational p-values (1000 randomizations) for relations between fish index of biotic integrity (Daniels et al. 2002,

McCormick wt al. 2001) metrics and nonmetric multidimensional scaling (NMDS) ordination for the fish community sampled during the summers of 2009 and 2010 from the Cacapon River, WV. An asterisk indicates significance at $\alpha=0.05$

\begin{tabular}{|c|c|c|c|}
\hline Index of Biotic Integrity & Metric & Vector $r^{2}$ & $\mathrm{P}$-value \\
\hline \multirow{12}{*}{ Daniels et al. (2002) Fish IBI } & Total richness & 0.425 & 0.150 \\
\hline & Benthic insectivores & 0.010 & 0.967 \\
\hline & Water column spp. & 0.290 & 0.282 \\
\hline & Terete minnows & 0.416 & 0.141 \\
\hline & Percent dominant & 0.436 & 0.126 \\
\hline & Percent Catostomus & 0.001 & 0.902 \\
\hline & Percent generalist & 0.223 & 0.386 \\
\hline & Percent insectivores & 0.073 & 0.768 \\
\hline & Per. top carnivores & 0.002 & 0.995 \\
\hline & Abundance & 0.181 & 0.484 \\
\hline & Per. juv. and adult & 0.420 & 0.134 \\
\hline & Percent anomalies & 0.706 & $0.001 *$ \\
\hline \multirow[t]{9}{*}{ McCormick et al. (2001) Fish IBI } & Non-tol. Cyprinids & 0.061 & 0.785 \\
\hline & Benthic spp. & 0.286 & 0.204 \\
\hline & Sensitive spp. & 0.099 & 0.699 \\
\hline & Percent Cottidae & 0.522 & 0.084 \\
\hline & Percent tolerant spp. & 0.310 & 0.268 \\
\hline & Percent exotic spp. & 0.652 & $0.023 *$ \\
\hline & Percent piscivores & 0.482 & 0.109 \\
\hline & Per. Macroomnivores & 0.077 & 0.755 \\
\hline & Per. grav. spawners & 0.214 & 0.401 \\
\hline
\end{tabular}


Appendix Ic: Example of a hand-drawn map of a centrarchid nesting area, used to relocate specific individuals and track nest reuse. Created May 2010.

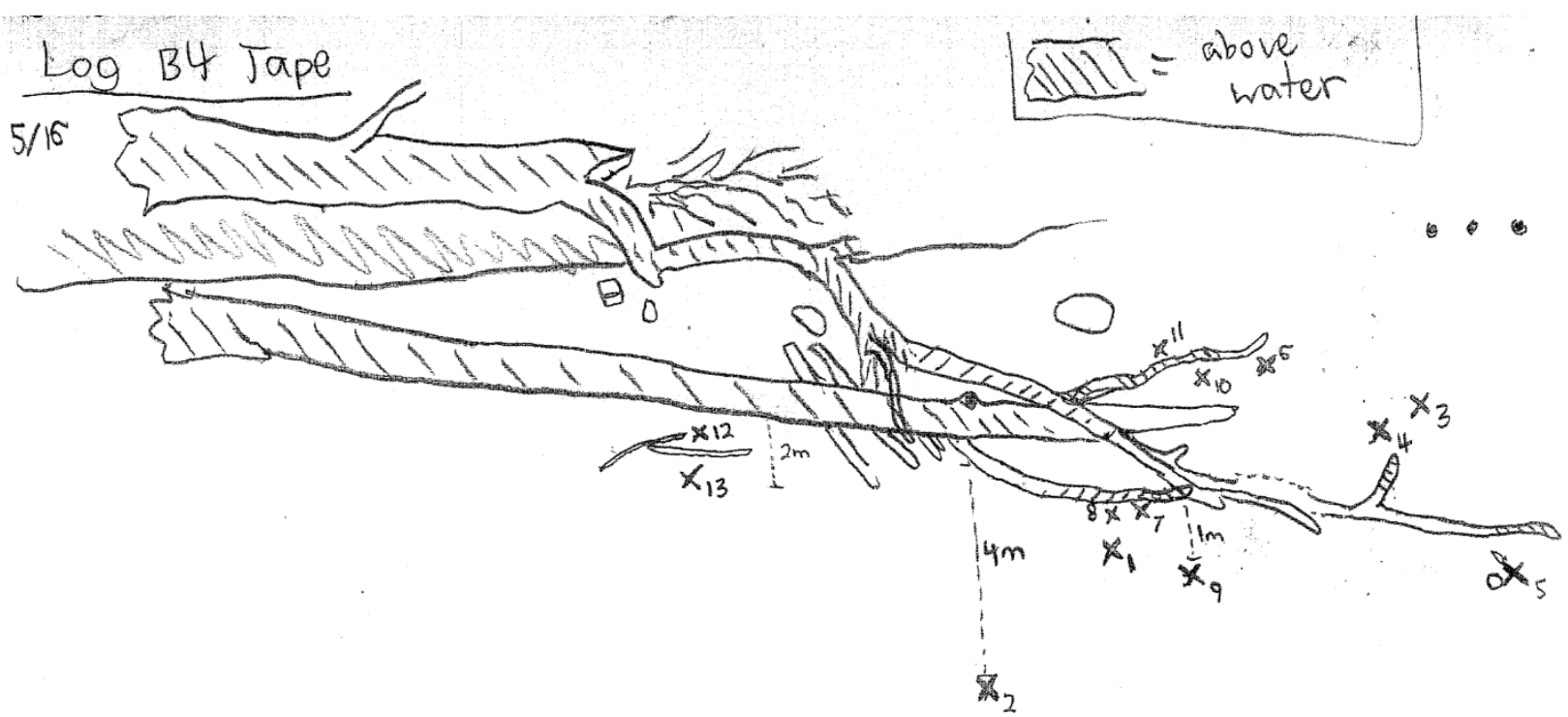

5/16 6in $6.5 \mathrm{in}$

RK bass: 2 (eg9s), 6 (eggs)

Bluegill: I (eggs, eaten by other Hargill)

$$
\stackrel{\uparrow}{(3.5 \mathrm{in})}
$$

$5 / 20$ : no nesting fish

$5 / 27:(12+)$ no nesting fish

$6 / 2: 10($ LEAU, 8 in) 
Appendix IIc: Graphical representation of the temporal range of nesting behavior among the four centrarchid species located in the Cacapon River.

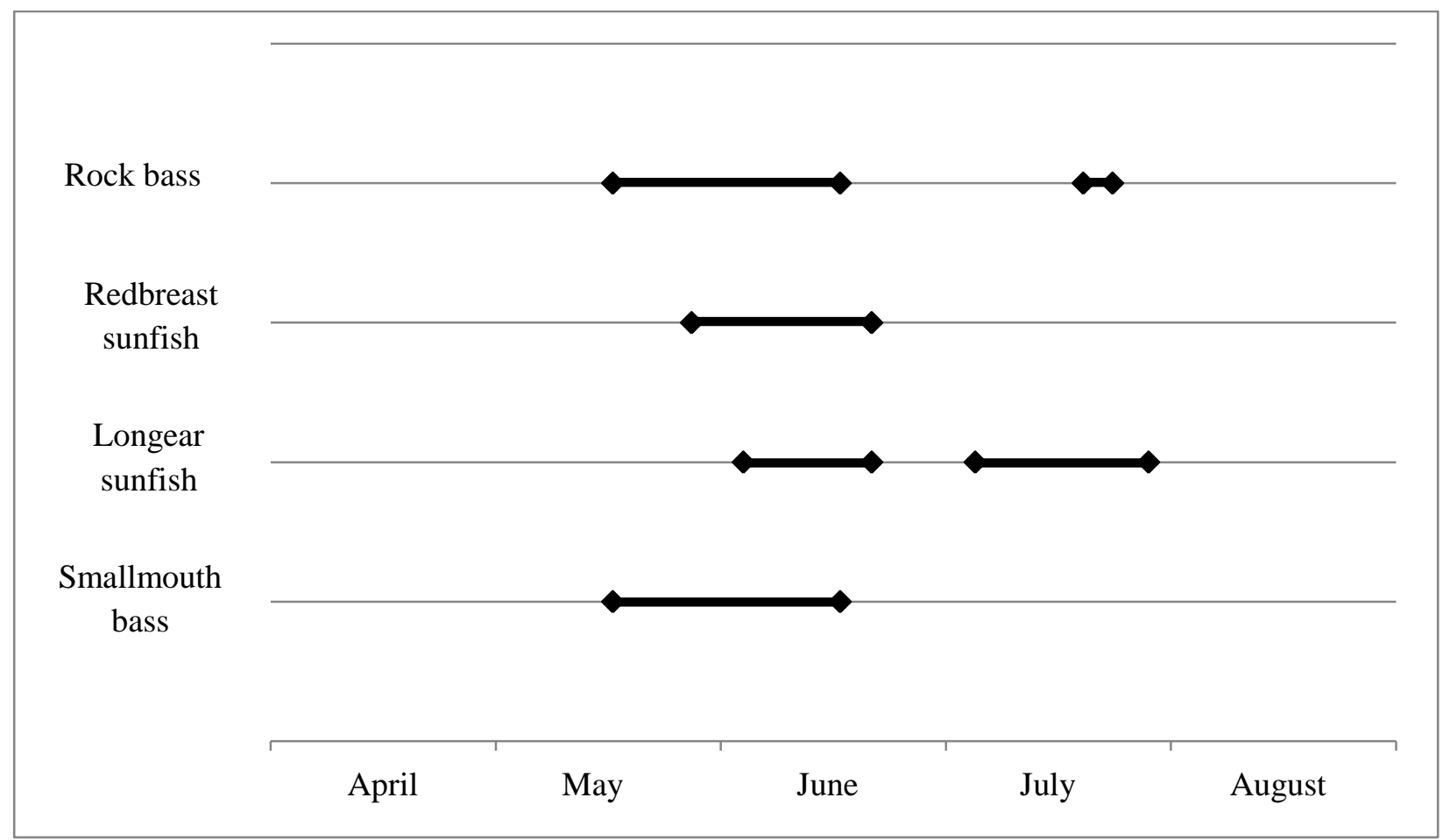


Appendix IIIc: Pie charts of substrate class composition in and around the nests of longear sunfish, visually assessed and averaged over each nest found.
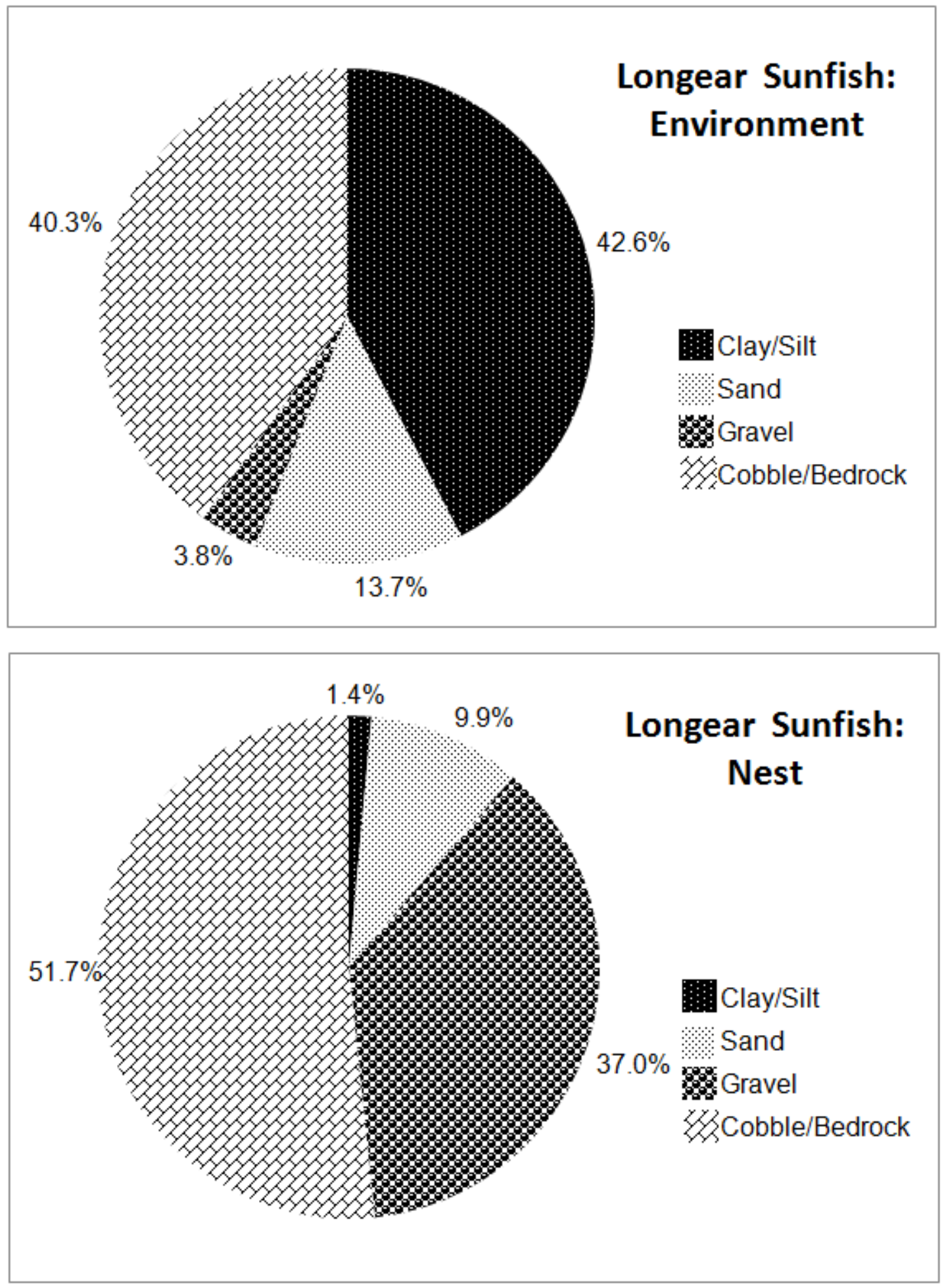
Appendix IVc: Pie charts of substrate class composition in and around the nests of rock bass, visually assessed and averaged over each nest found.
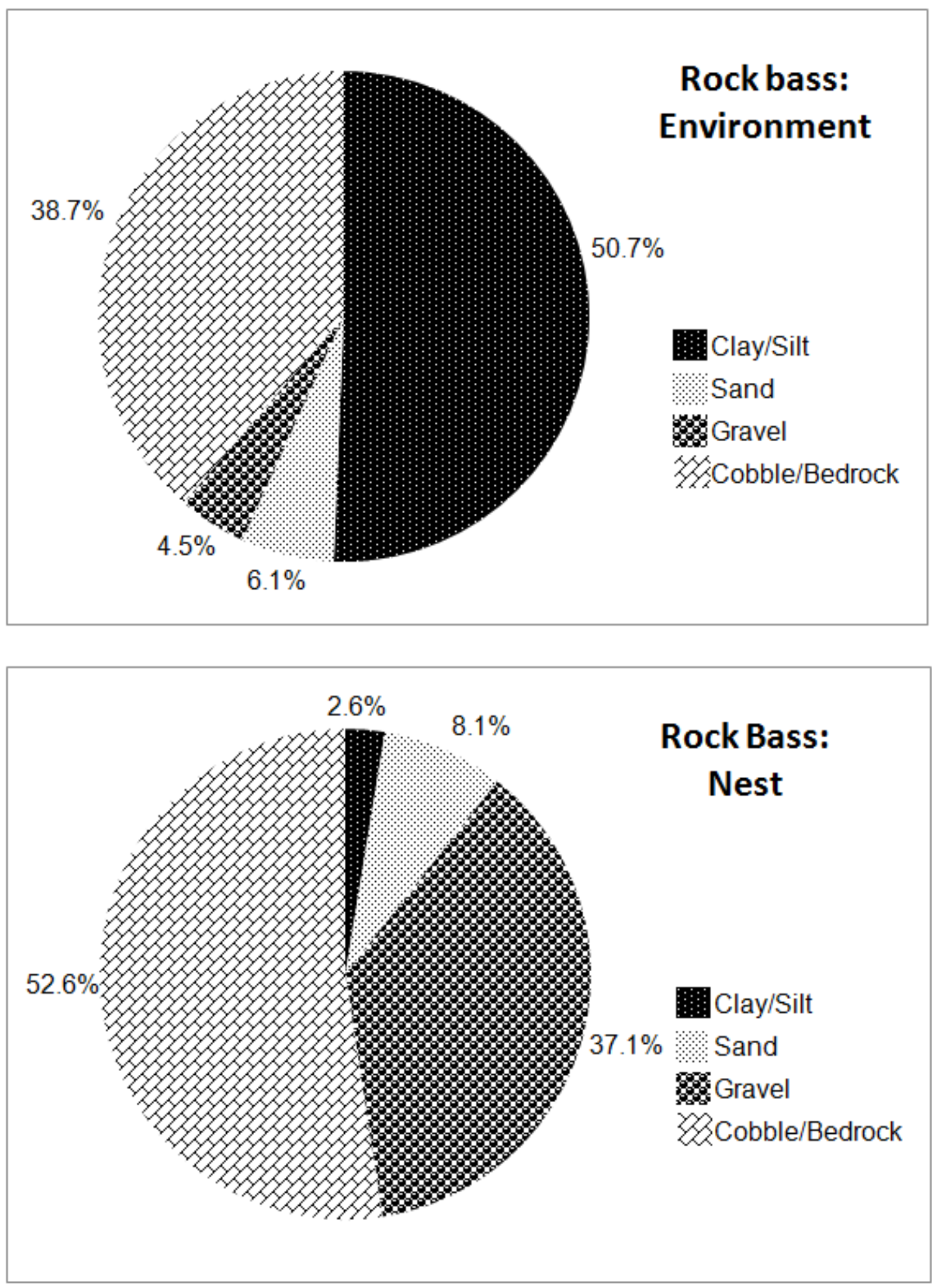
Appendix Vc: Pie charts of substrate class composition in and around the nests of redbreast sunfish, visually assessed and averaged over each nest found.
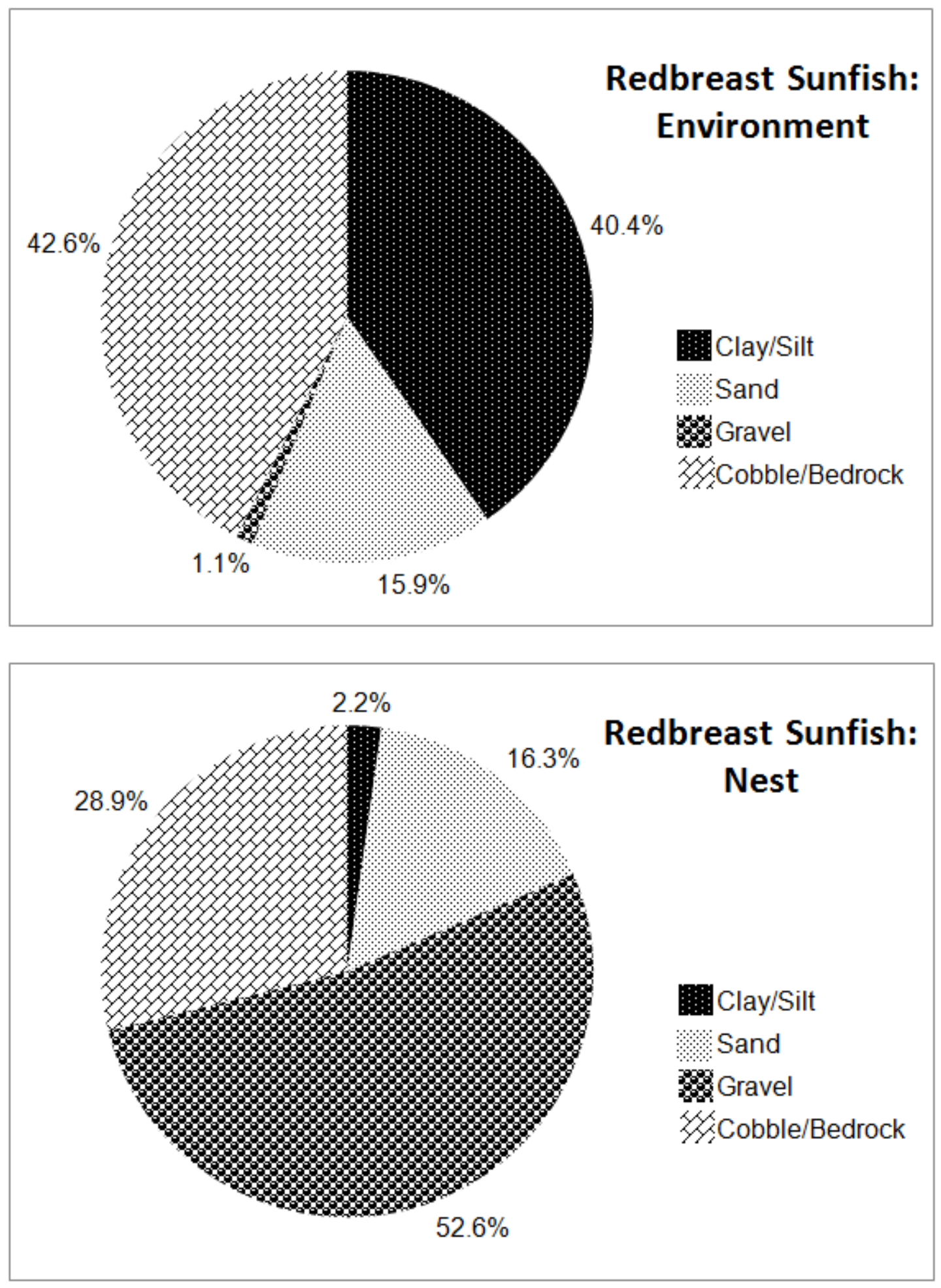
Appendix VIc: Pie charts of substrate class composition in and around the nests of smallmouth bass, visually assessed and averaged over each nest found.
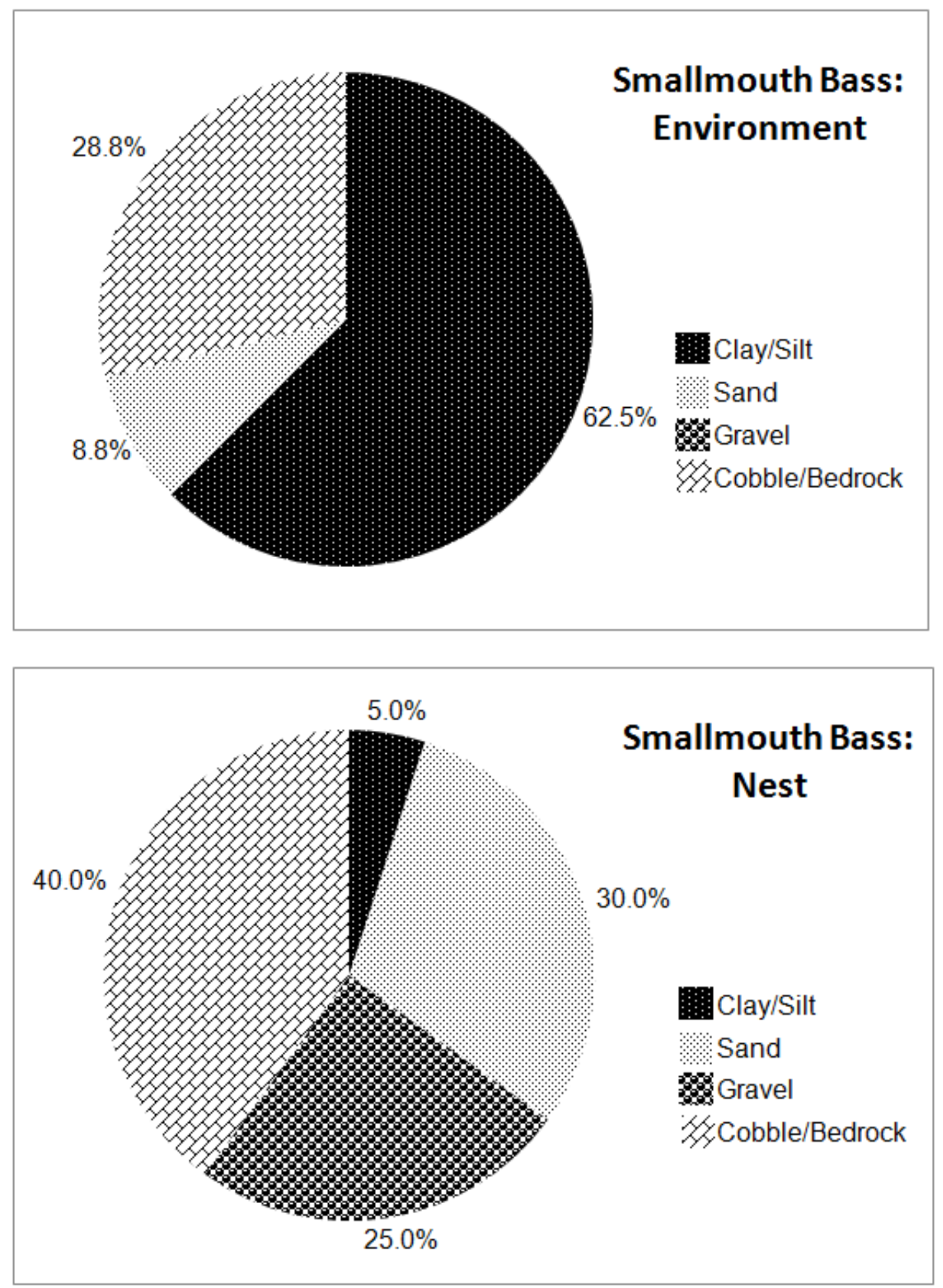
Appendix VIIc: Pie chart of substrate class composition at the random sites within the centrarchid nesting stretch, visually assessed and graphically averaged across all sites sampled.

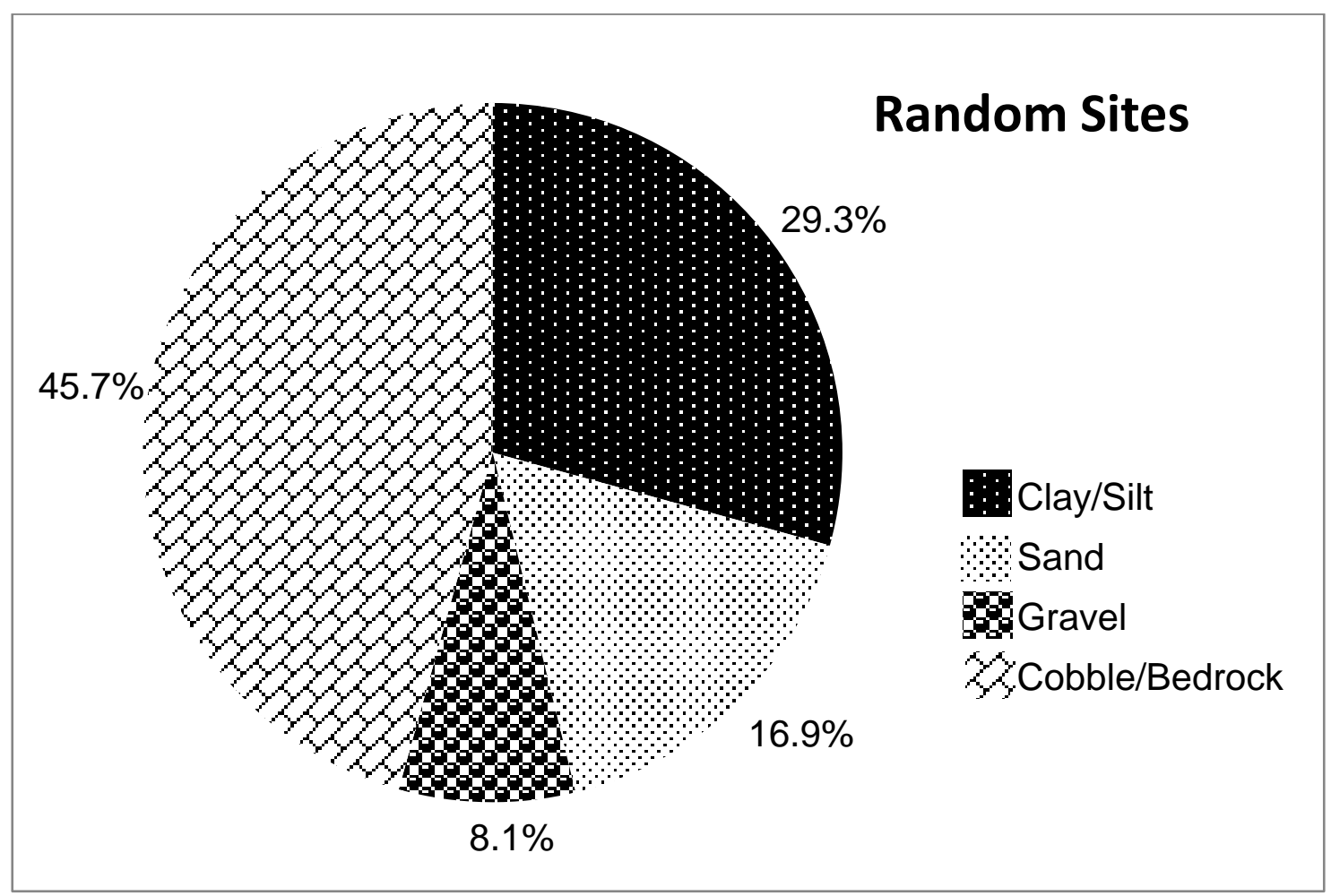


Appendix VIIIc: Nonmetric multidimensional scaling (NMDS) ordination plot $(\mathrm{k}=3)$ for longear sunfish nests $(\mathrm{M})$ and random sites $(\mathrm{r})$, with environmental variable overlay. Stress $=15.87$.

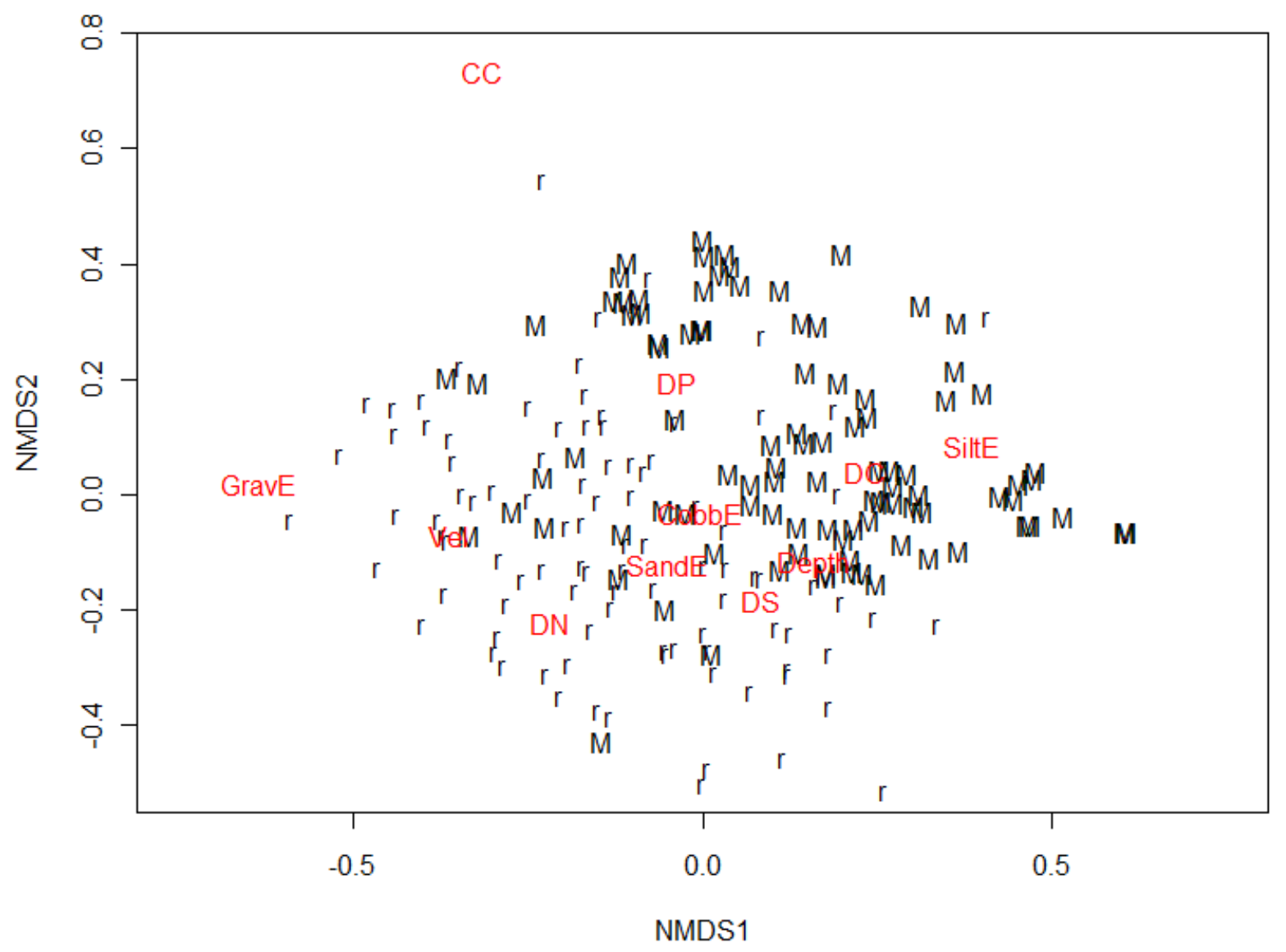


Appendix IXc: Nonmetric multidimensional scaling (NMDS) ordination plot $(\mathrm{k}=3)$ for rock bass nests (A) and random sites (r), with environmental variable overlay. Stress $=15.43$.

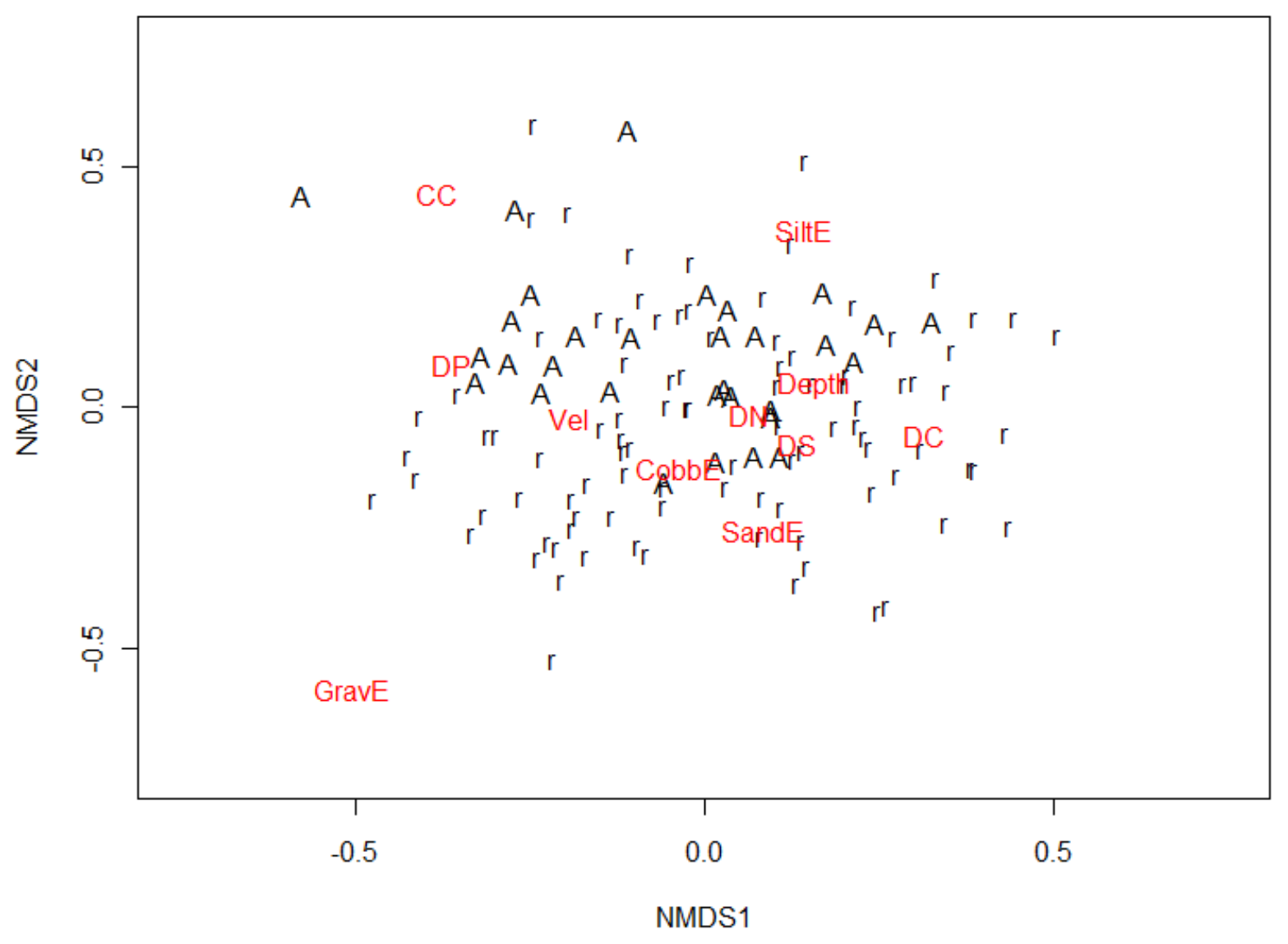


Appendix Xc: Nonmetric multidimensional scaling (NMDS) ordination plot $(\mathrm{k}=3)$ for redbreast sunfish nests (U) and random sites (r), with environmental variable overlay. Stress=15.07.

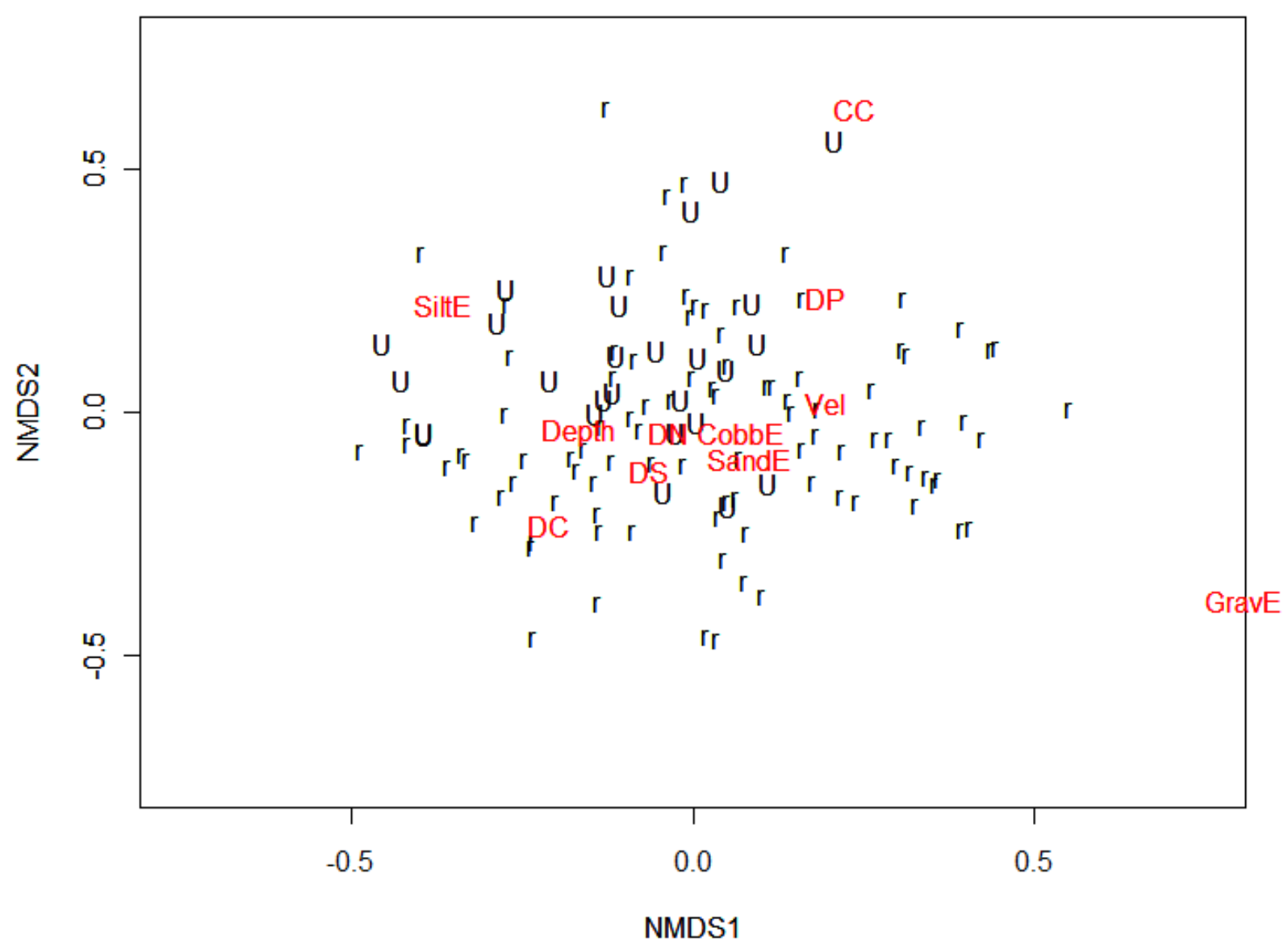


Appendix XIc: Nonmetric multidimensional scaling (NMDS) ordination plot $(\mathrm{k}=3)$ for smallmouth bass nests ( $\mathrm{S}$ ) and random sites (r), with environmental variable overlay. Stress $=14.14$.

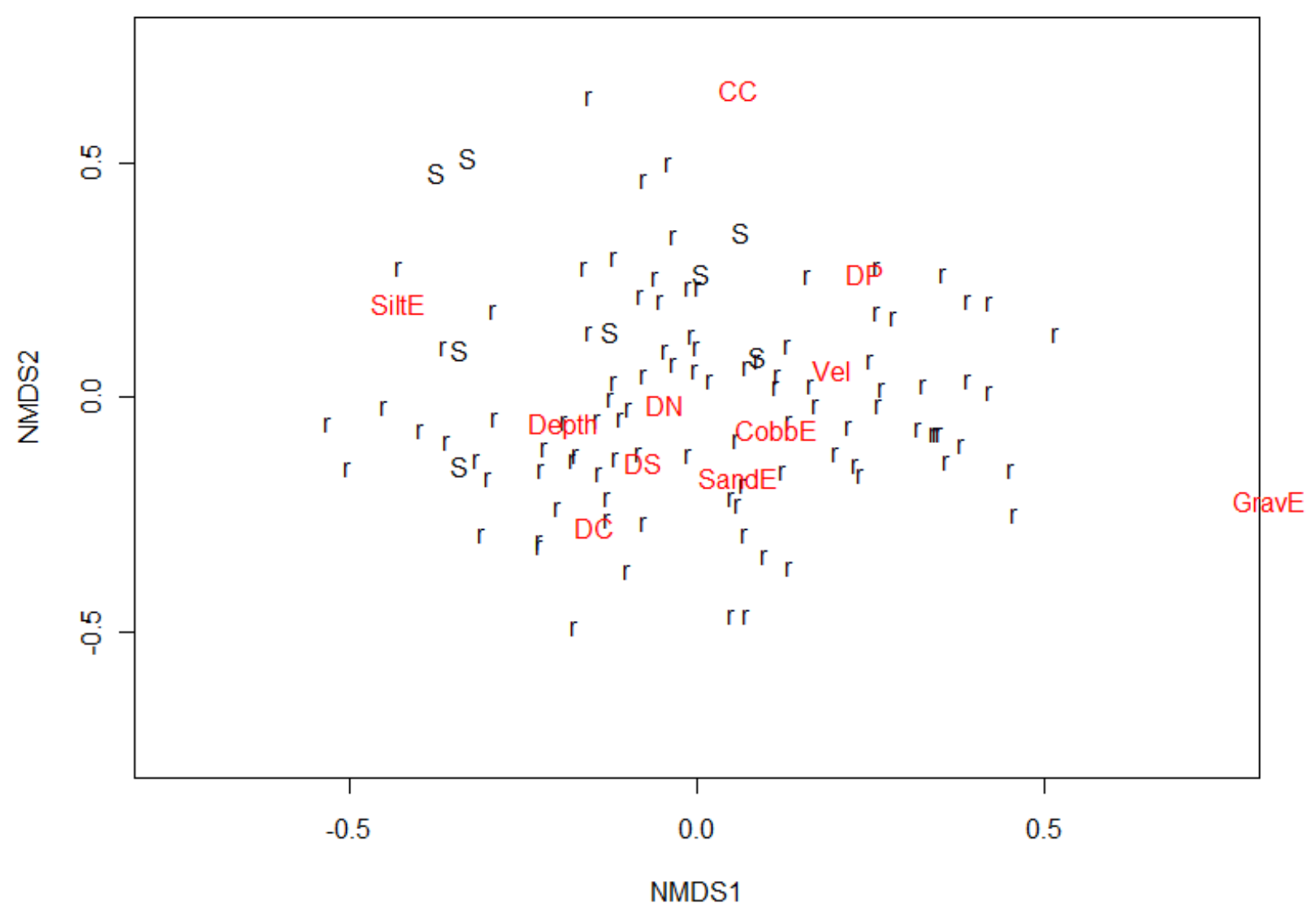


Appendix XIIc: Nonmetric multidimensional scaling (NMDS) ordination plot $(\mathrm{k}=3)$ for longear sunfish nests (M) and rock bass nests (A), with environmental variable overlay. Stress=16.60.

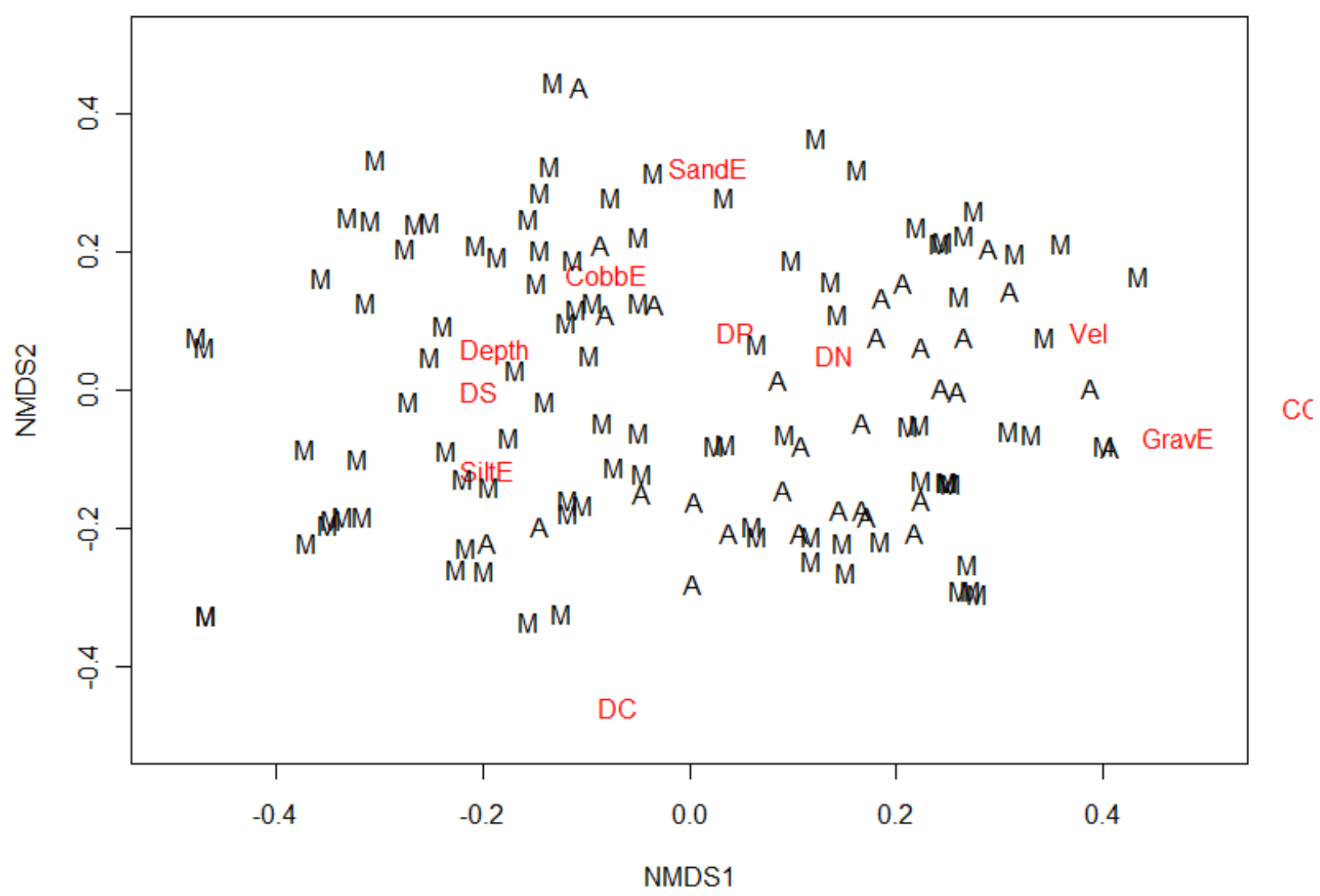


Appendix XIIIc: Nonmetric multidimensional scaling (NMDS) ordination plot $(\mathrm{k}=3)$ for longear sunfish nests (M) and redbreast sunfish nests (U), with environmental variable overlay.

Stress $=15.48$.

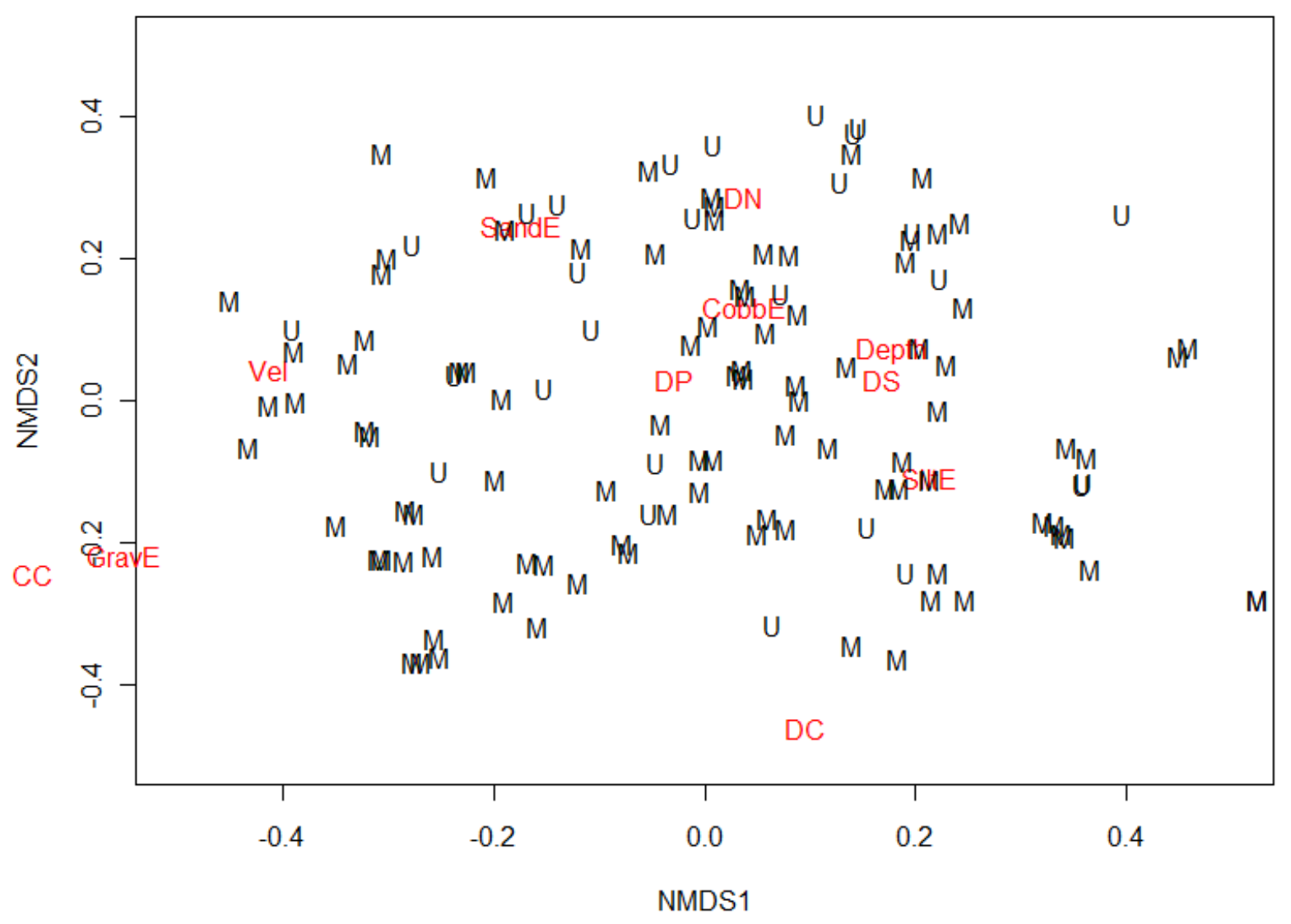


Appendix XIVc: Nonmetric multidimensional scaling (NMDS) ordination plot $(\mathrm{k}=3)$ for longear sunfish nests (M) and smallmouth bass nests (S), with environmental variable overlay.

Stress $=14.61$.

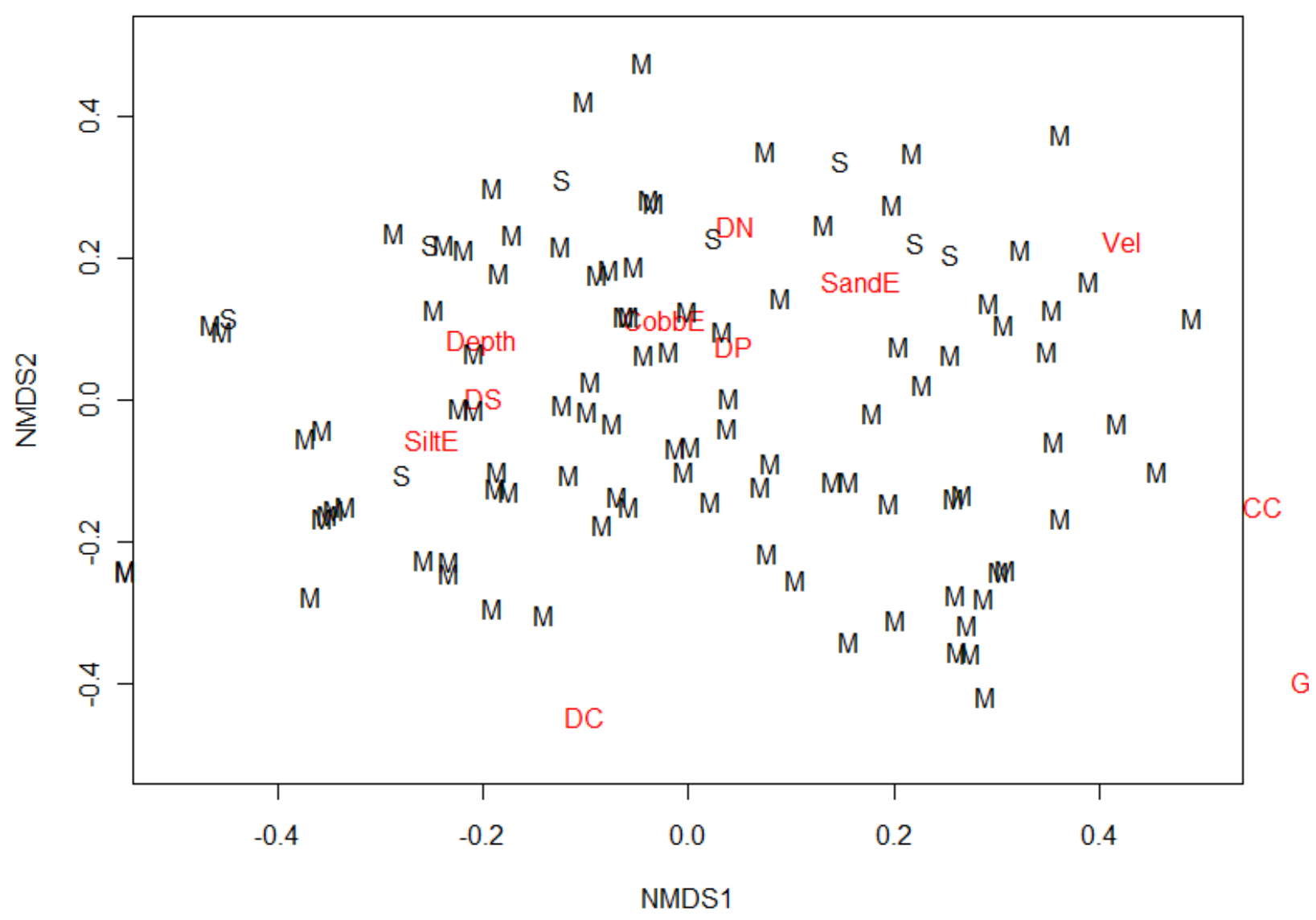


Appendix XVc: Nonmetric multidimensional scaling (NMDS) ordination plot $(\mathrm{k}=3)$ for redbreast sunfish nests (U) and rock bass nests (A), with environmental variable overlay. Stress $=15.42$.

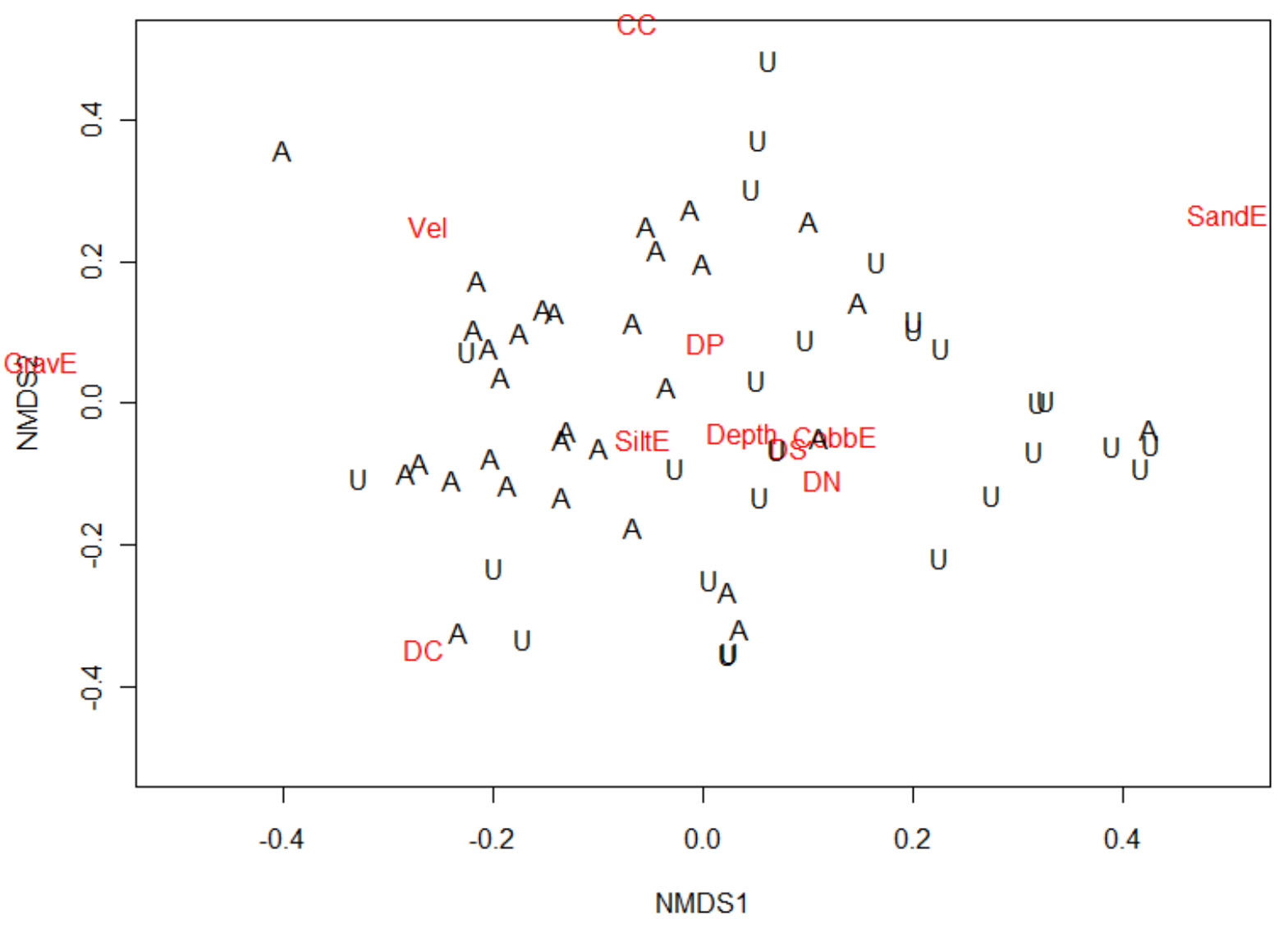


Appendix XVIc: Nonmetric multidimensional scaling (NMDS) ordination plot $(\mathrm{k}=3)$ for smallmouth bass nests (S) and rock bass nests (A), with environmental variable overlay. Stress $=13.43$.

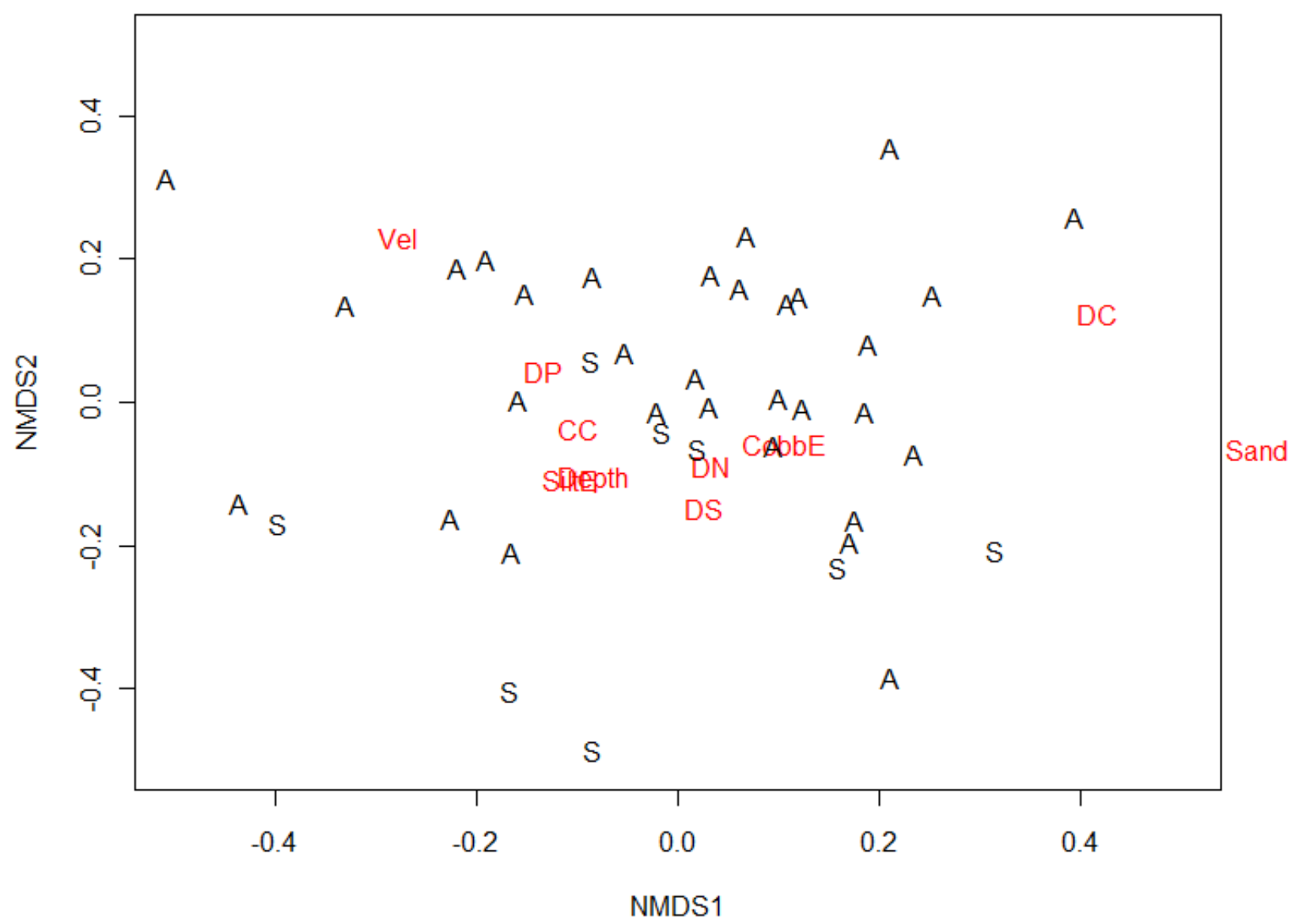


Appendix XVIIc: Nonmetric multidimensional scaling (NMDS) ordination plot ( $\mathrm{k}=3$ ) for redbreast sunfish nests (U) and smallmouth bass nests (S), with environmental variable overlay. Stress $=12.27$.

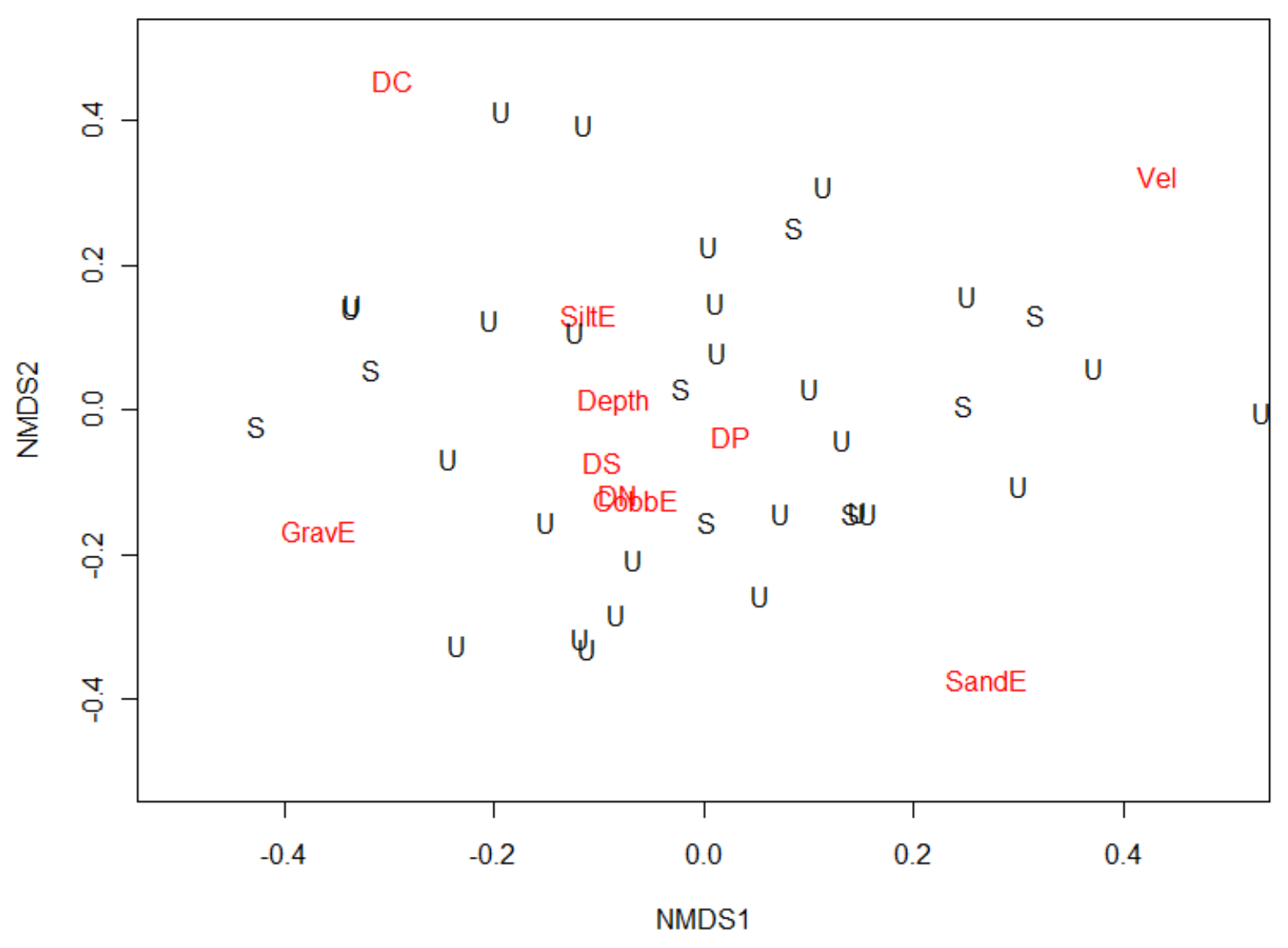


Appendix XVIIIc: Results for occupancy estimations conducted on 30 nesting longear sunfish males $(n=30)$, and approached 5 times each $(\mathrm{k}=5)$, following the Geissler Fuller (G.F. method). Average detection probability across all surveys was 0.719 .

\begin{tabular}{|c|c|c|c|}
\hline Survey & First detection & Detections after first & G.F. probability \\
\hline 1 & 1 & 3 & 0.75 \\
\hline 2 & 1 & 3 & 0.75 \\
\hline 3 & 1 & 4 & 1 \\
\hline 4 & 1 & 4 & 1 \\
\hline 5 & 1 & 4 & 1 \\
\hline 6 & 1 & 3 & 0.75 \\
\hline 7 & 1 & 1 & 0.25 \\
\hline 8 & 1 & 1 & 0.25 \\
\hline 9 & 1 & 4 & 1 \\
\hline 10 & 2 & 1 & 0.33 \\
\hline 11 & 1 & 4 & 1 \\
\hline 12 & 2 & 3 & 1 \\
\hline 13 & 1 & 3 & 0.75 \\
\hline 14 & 1 & 2 & 0.5 \\
\hline 15 & 1 & 2 & 0.5 \\
\hline 16 & 1 & 2 & 0.5 \\
\hline 17 & 3 & 1 & 0.5 \\
\hline 18 & 1 & 4 & 1 \\
\hline 19 & 1 & 4 & 1 \\
\hline 20 & 1 & 3 & 0.75 \\
\hline 21 & 1 & 3 & 0.75 \\
\hline 22 & 1 & 4 & 1 \\
\hline 23 & 1 & 3 & 0.75 \\
\hline 24 & 1 & 2 & 0.5 \\
\hline 25 & 1 & 4 & 1 \\
\hline 26 & 1 & 2 & 0.5 \\
\hline 27 & 1 & 4 & 1 \\
\hline 28 & 2 & 0 & 0 \\
\hline 29 & 2 & 3 & 1 \\
\hline 30 & 3 & 1 & 0.5 \\
\hline
\end{tabular}

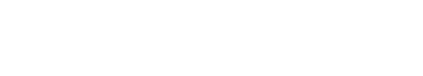

